Universidade de São Paulo

Faculdade de Filosofia, Letras e Ciências Humanas

Departamento de Geografia

\title{
DINÂMICA DA ÁGUA EM CAMPOS DE MURUNDUS DO PLANALTO DOS PARECIS
}

Prudêncio Rodrigues de Castro Júnior

Prof. Dr. José Roberto Tarifa

Orientador

Tese apresentada ao Departamento de Geografia da Faculdade de Filosofia Letras e Ciências Humanas da Universidade de São Paulo, para obtenção do grau de DOUTOR em Geografia Física

São Paulo

2002 
Dedico este trabalho

Com admiração e respeito, à memória do senhor José Vilmar Knapik, verdadeiro representante das inúmeras famílias de lavradores que vieram dos Estados do sul do País, colonizar o norte de Mato Grosso. 
Dedico também

com gratidão e saudade, à memória da digníssima $\operatorname{Prof}^{\mathfrak{a}}$ Dunga Rodrigues, legítima representante da cultura e do viver cuiabanos, amiga que acreditou em mim e torceu pelo meu êxito profissional;

com louvor e afeto, ao magnífico reitor Benedito Pedro Dorileo, grande sustentáculo da UFMT, que me concedeu a oportunidade iniciar o exercício da docência em 1981, na condição de professor auxiliar de ensino;

com amor e júbilo, à minha esposa Regina Néris de Assunção e Castro, e às minhas filhas Sofia e Sílvia Assunção Castro, que vem me trazendo tantas alegrias, renovando-me a vida e o estímulo ao trabalho. 


\section{Agradecimentos}

- Ao Prof. Dr. José Roberto Tarifa, que de forma amiga e humana aceitou dar continuidade a orientação deste trabalho, garantindo-me a tranqüilidade necessária para chegar a este final;

- A Profa . Dr. ${ }^{a}$ Selma Simões de Castro, pela orientação inicial, participação na primeira fase dos trabalhos de campo e pelos encantos da micromorfologia dos solos;

- Ao Prof. Dr. Fernando Ximenes de Tavares Salomão, co-orientador, que acompanhou todas as fases do trabalho e fez a revisão da versão final, prestando sempre o auxílio essencial;

- Profa. Dr. ${ }^{a}$ Rosely Pacheco Dias Ferreira, pela boa acolhida no Laboratório de Pedologia do Departamento de Geografia da USP, e pelas boas orientações prestadas durante o exame de qualificação;

- Ao Prof. Dr. Jurandyr Luciano Sanches Ross, com quem tive oportunidade de fazer boas reflexões sobre a relação entre geomorfologia, sociedade e natureza e pelas boas sugestões durante o exame de qualificação;

- A Prof ${ }^{a}$. Dr. ${ }^{a}$ Lilyan Coltrinari, que me proporcionou bons conhecimentos sobre evolução de vertentes e geomorfologia climática;

- À Prof ${ }^{a}$. Dr. ${ }^{a}$ Célia Alves Borges, pela disposição e boa vontade com que auxiliou os trabalhos de campo;

- À Prof ${ }^{a}$. Dr. ${ }^{a}$ Denise Sette, pela intermediação na mudança de orientador, bem como pela colaboração na abordagem e discussão dos aspectos climatológicos desta pesquisa;

- À Prof ${ }^{a}$. Dr. ${ }^{a}$ Cleuza Zamparoni, pela discussão dos dados climatológicos;

- Aos professores Aló́sio Borba, Cátia Cunha, Eduardo do Couto Guimarães, Emílio Azevedo, Fernando Shirashi e Joaquim Correa Ribeiro da UFMT, que forneceram-me importantes publicações utilizadas neste trabalho;

- Ao Prof. Arnaldo Sakamoto, da UFMS, campus de Três Lagoas, pela construção e doação pio, instrumento simples, pequeno, mas imprescindível nesta pesquisa; 
- Ao geólogo Salatiel Alves de Araújo, pelos trabalhos de geoprocessamento e representação gráfica das trincheiras, sondagens e topossequências.

- Ao químico José Joaquim de Souza Neto, ao técnico Paulo César de Medeiros Silva e equipe técnica do Laboratório Agroanálise, pela forma competente e camarada com que fizeram as análises físicas e químicas de solo

- Ao eng. ${ }^{0}$ agr. ${ }^{\circ}$ Reginaldo Bosco Gomes, pelo auxílio na interpretação das análises de solo;

- Ao eng. ${ }^{\circ}$ agr. ${ }^{\circ}$ Bernardino Pedro da Silva da empresa Serviços Agronômicos Ltda. - SEAGRO, pela colaboração na escolha da área de pesquisa;

- Ao eng. ${ }^{\circ}$. agr. ${ }^{\circ}$ Levy Fonseca Neto, pelo auxílio nadiscução das análises de solo;

- Ao Prof. Zacarias Mayal Filho, pela busca e empréstimo das fotografia aéreas;

- Ao Alexandrino Leite Nascimento, técnico do Departamento de Geologia Geral, pela disposição trabalhar no campo confeccionado e instalando piezômetros;

- Ao eng ${ }^{0}$. agr ${ }^{\circ}$. Luiz Trevisan, proprietário da Drenomat, que forneceu material sobre a drenagem de solos em Mato Grosso;

- A Olívio Roberto Naumann, o alemão, pelo inestimável auxílio na abertura de trincheiras, instalação dos piezômetros e monitoramento do nível d'água do solo durante 14 meses, bem como aos trabalhadores anônimos que também abriram trincheiras;

- A toda família Knapik, Sr. José Wilmar (em memória), Sr. João, proprietários da Fazenda São Fidel , esposas e filhos, pela colaboração, boa vontade e hospitalidade durante todo o trabalho;

- Ao Marcelo Knapik, pelo inestimável auxílio nos trabalhos de campo, especialmente nas tradagens;

- A Marcielle Knapik, pela coleta cuidadosa dos dados pluviométricos;

- Ao Reinaldo Lossi, outro alemão, secretário de agricultura e meio ambiente de Sorriso, que abriu as portas do município para a realização deste trabalho; 
- A Lenira Arsego, da Secretaria de Agricultura de Sorriso, pelo equipamento e preciosos dados pluviométricos fornecidos;

- A Sr. ${ }^{a}$ Tarita Lacerda, da J. Prolab, pelos pluviômetros e material bibliográfico enviados;

- A Floripes Piné Garcia, do Laboratório de Pedologia do Departamento de Geografia Física da USP, pela forma amiga e carinhosa com que cuidou da minha situação burocrática junto a secretaria do curso;

- A Esther Nebenzhal Guimarães, Pierre Girard e Rosimeyre Portela pelo auxílio nas traduções;

- As secretarias do Curso de Pós-Graduação em Geografia da USP, Ana, Rose e Jurema, pelo atendimento gentil e amigo que sempre me dispensaram;

- Ao Miguel, do Laboratório de Solos da UFMT, pelo auxílio na tentativa de impregnar as amostras, e a Verônica, do Laboratório da Geociências da USP, pela impregnação das amostras

- Ao geógrafo Maurício Alves da Silva, pela representação dos perfiz de sondagem;

- A Elizabeth Köck Carvalho Netto, pelo auxílio na composição gráfica e editoração do texto;

- A minha irmã, Elizabeth Rodrigues de Castro, pela guarida em sua residência na cidade de São Paulo, quando completava os créditos;

- A minha esposa Regina Néris de Assunção e Castro, pela colaboração durante todo o trabalho, especialmente pela tranqüilidade proporcionada na fase de redação;

- A Coordenação de Aperfeiçoamento de Pessoal de Nível Superior CAPES, pela concessão da bolsa;

- Ao Prof. Adolpho Eurípedes, digno chefe do Departamento de Geografia da UFMT, e a todos os colegas do Departamento, pela camaradagem e colaboração durante o período de realização da tese;

- A Pro-Reitoria de Pesquisa Ensino de Pós-Graduação da UFMT, especialmente aos professores José Holanda Campelo Júnior, Norman Barros Logsdon, Flávia Maria de Barros Nogueira e Maria das Graças Martins da Silva, bem como à competente funcionária Mariete Fátima de Arruda 


\section{RESUMO}

A dinâmica da água em campos de murundus do Planalto dos Parecis é estudada neste trabalho por meio de observações de campo realizados na Fazenda São Fidel, município de Sorriso, estado de Mato Grosso. Esses campos, nitidamente dependentes do regime pluvial, possuem grande importância para a conservação da água de superfície e da biodiversidade, por estarem diretamente ligados aos cursos d'água formadores das bacias hidrográficas, como também por abrigar numerosas espécies florísticas e faunísticas do cerrado brasileiro

O trabalho tem como objetivo principal conhecer a dinâmica da água e a estrutura pedológica de um campo de murundus, também conhecidos como microrrelevos, e regionalmente, por monchões, cocorutos, covoais, ilhas e capãozinhos, utilizando-se de revisão bibliográfica, interpretação de imagens de satélite e fotografias aéreas, levantamento dos solos com procedimentos da análise estrutural da cobertura pedológica, e estudos climatológicos, por meio da análise de dados pluviométricos a partir de 1985 e de dados piezométricos obtidos durante coleta sistemática em duas vertentes representativas de um campo de murundus do Planalto.

Os principais resultados obtidos, referem-se à origem dos murundus por diferentes teorias, uma geomorfológica e outra biológica, estas paisagens ocorrem ao redor dos cursos d'água formadores da bacia hidrográfica, apresentando configuração e distribuição distinta em cada setor da vertente. Nos campos de murundus estudados o solo que ocorre na base da vertente é o PLINTOSSOLO ARGILÚVICO Distrófico, enquanto que na parte média e superior da vertente ocorre o LATOSSOLO BRUNO 
Distrófico câmbico e o Distroférrico plíntico, sendo que a característica comum e notável destes solos é a presença de concreções ferruginosas formando o horizonte plíntico, correspondendo ao nível de oscilação do lençol freático.

A dinâmica da água nos campos de murundus possui comportamento peculiar, diretamente ligado ao regime pluviométrico, mantendo-se saturados ou supersaturados em água nos meses chuvosos, esvaziando-se lenta e continuamente nos meses secos, por meio do rebaixamento do nível freático a uma taxa média de $17 \%$ ao mês. $O$ estudo realizado indica a presença de dois lençóis, um suspenso de características sazonais e outro perene e profundo, separado do anterior por uma camada argilosa confinante.

Os dados obtidos foram utilizados no sentido de compreender a dinâmica hídrica nos campos de murundus, bem como a estrutura pedológica, o regime pluviométrico, o comportamento piezométrico, as relações com a rede hidrográfica, a sua função no bioma do cerrado, e ainda avaliar o impacto ambiental, devido ao rebaixamento do nível freático por meio da escavação de uma rede de drenos, possibilitando assim a prática da agricultura mecanizada nessas áreas naturalmente impróprias. 


\begin{abstract}
Water dynamics in earth mound (murundus) of the "Parecis" plateau, was studied at the São Fidel farm, municipality of Sorriso, state of Mato Grosso. These fields, essentially dependent on pluvial waters, are of great importance for conservation of surface and biodiversity, once they are directly linked to streams feeding the hydrographic basins as well as providing shelter to a wide diversity of species from the flora and fauna of the Brazilian savanna.
\end{abstract}

The main purpose of this research is to understand the water dynamics and the pedologic structure of murundus fields,also known as microrelieves, and regionally known as monchões, cocorutos, covoais, isles and capãozinhos. The research tools applied include bibliographic revision, interpretation of satellite images and aerial photography, soil samples and corresponding structural and pedologic analysis, climatological studies by means of the anlysis of the pluviometric record starting from 1985 and of piezometric data systematically obtained from two typical slopes in a murundus field of the Planalto.

The main results aer discussed within the frame os two distinct theories about the origin of mounds, one geomorphological and the other biological. These formations occur along the head watercourses of the hydrigraphic basin and they show a distinctive configuration and distribution with different sections of the slope. In these fields, the soil at the slope base corresponds to dystrophic argillaceous plinth soil, whilst on the medium and superior section of the slope the soil corresponds to the dystrophic cambric (LATOSSOLO BRUNO) and dystroferric plinth. The 
distinctive and outstanding characteristic of both types of soil is the presence of ferruginous concretions along the plinth corresponding the phreatic oscillation levels.

Water dynamics in these fields has a distinctive behavior directly related to the pluviometric regime. The are water saturated or supersaturated during the rainy season and during the dry season they progresssively loose their water by mean of the lowering of the phreatic level at an average rate of $17 \%$ per month. The research indicated the presence of two water sheets, one temporary and dependent on seasonal changes and a second deep and perennial, separated one from another by a confined argillous stratum.

The data was used to further understand the water dynamics in murundus fields as well as the pedagogic structure, the pluviometric regime, the piezometric behavior, the relationship with the hydrographic system, their role in the bio-system of the savanna, and, furthermore, to assess the ecological impact of the artificial decrease in the phreatic level brought about by a drainage system allowing for mechanized agriculture in these areas naturally inappropriate for farming. 


\section{SUMÁRIO}

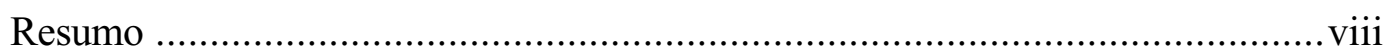

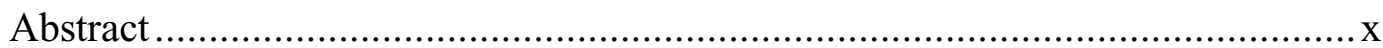

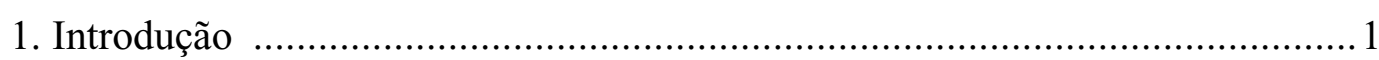

1.1. Fundamentos teóricos e metodológicos da pesquisa ..........................................

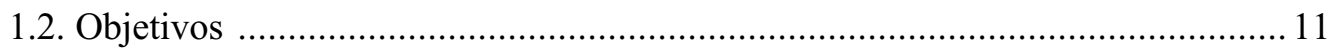

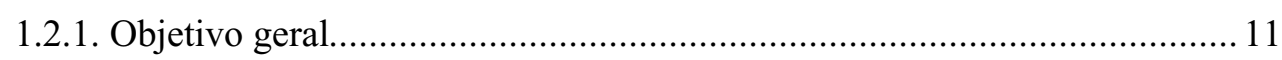

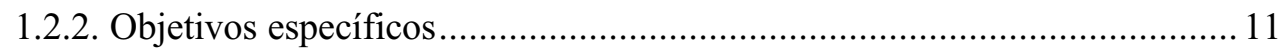

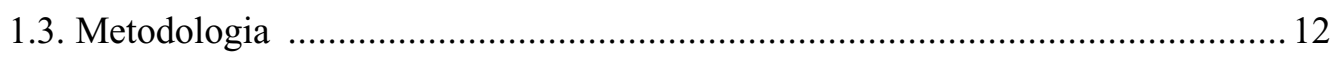

1.3.1. Compartimentação morfopedológica ..................................................... 12

1.3.2. Caracterização das coberturas pedológicas.............................................. 14

1.3.3. Comportamento hídrico das vertentes e definição do sistema pedológico .. 15

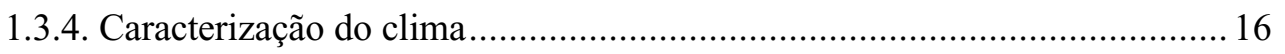

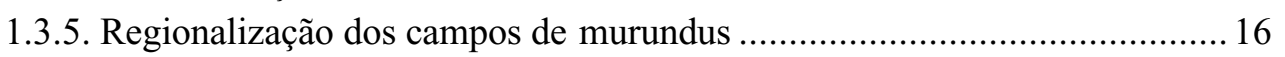

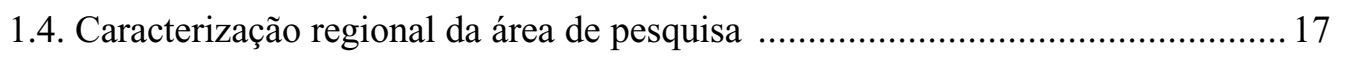

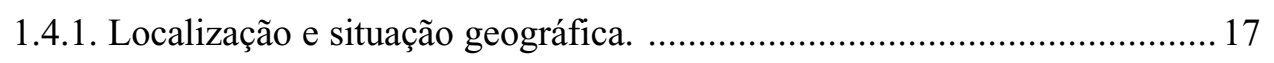

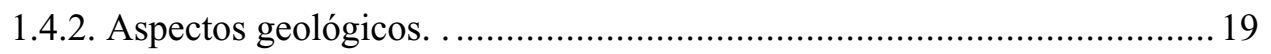

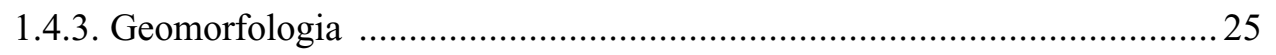

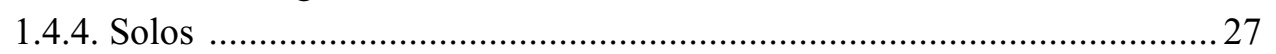

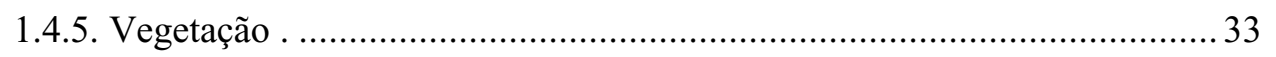

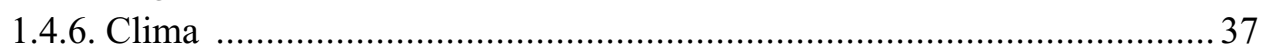

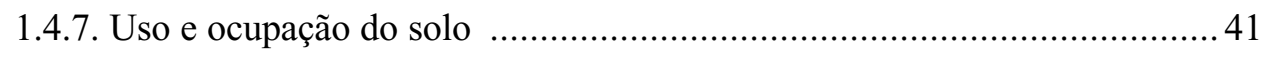

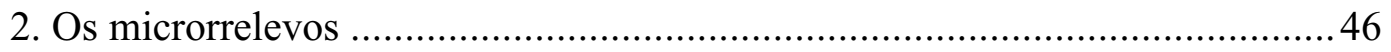

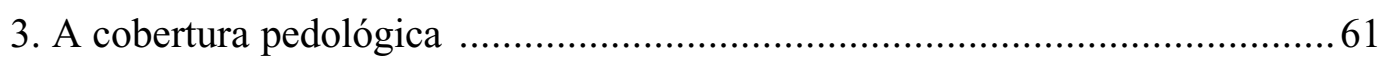

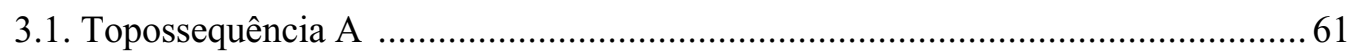

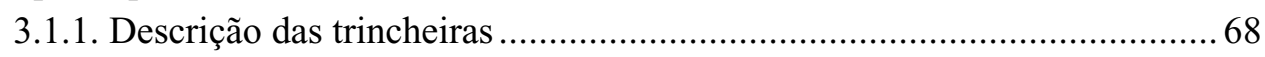

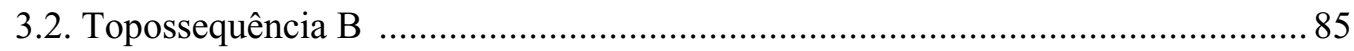

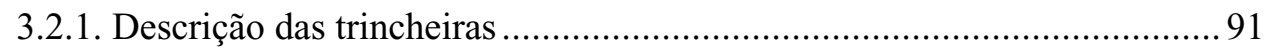

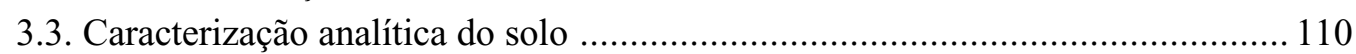

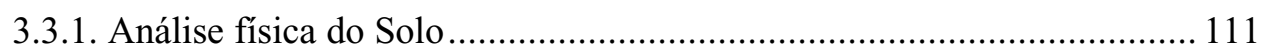

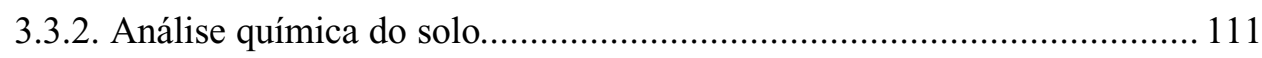

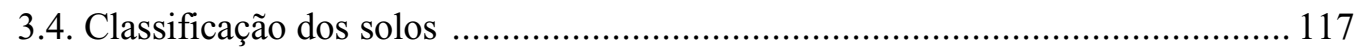

4. A dinâmica hídrica ................................................................................ 120

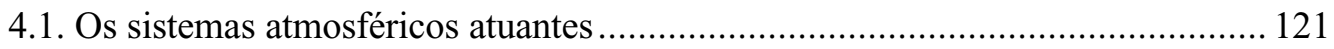

4.2. A estrutura pluvial do Planalto dos Parecis...................................................... 128

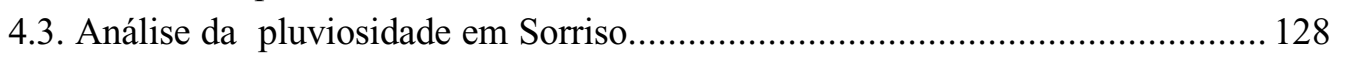

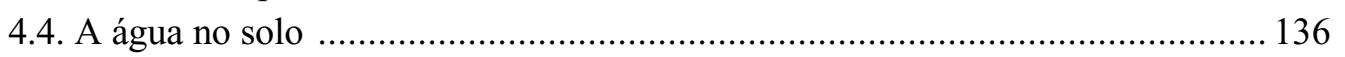

5. Considerações finais ….......................................................................... 154

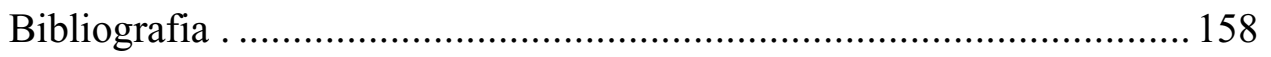

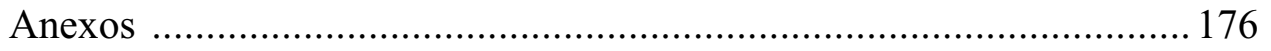




\section{ÍNDICE DAS FIGURAS}

Figura $\mathrm{n}^{\mathrm{o}}$ 1: Localização da área. .............................................................. 18

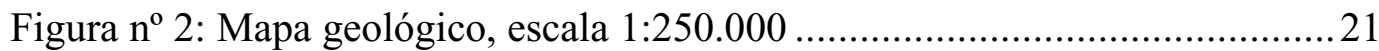

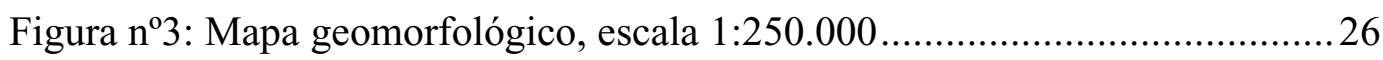

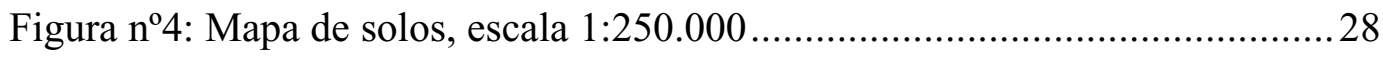

Figura $n^{0}$ 5: Mapa de vegetação, escala 1:250.000 ...........................................35

Figura $\mathrm{n}^{\mathrm{o}}$ 6: Perfil esquemático da savana parque............................................ 36

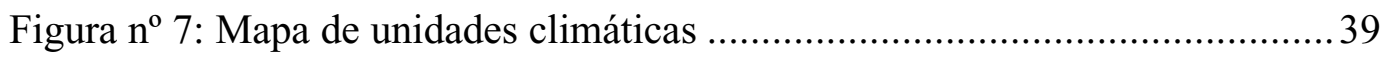

Figura $n^{\circ}$ 8: Mapa de ocupação e uso do solo, escala 1:75.000 …......................42

Figura $n^{0}$ 9: Representação da toposequencia A …...........................................67

Figura $\mathrm{n}^{\circ} 10$ : Configuração esquemática da trincheira TRA1 ........................... 70

Figura $\mathrm{n}^{\mathrm{o}}$ 11: Configuração esquemática da trincheira TRA2 ......................... 75

Figura $\mathrm{n}^{\mathrm{o}}$ 12: Configuração esquemática da trincheira TRA3 .......................... 78

Figura $\mathrm{n}^{\mathrm{o}}$ 13: Configuração esquemática da trincheira TRA4 …........................8 83

Figura $\mathrm{n}^{\mathrm{o}}$ 14: Representação da topossequencia B ......................................... 90

Figura $n^{0}$ 15: Configuração esquemática da trincheira TRB1..........................93

Figura $\mathrm{n}^{\circ} 16$ : Configuração esquenática da trincheira TRB2 ............................96

Figura $\mathrm{n}^{\circ}$ 17: Configuração esquemática da trincheira TRB3 ........................... 99

Figura $\mathrm{n}^{\mathrm{o}}$ 18: Configuração esquemática da trincheira TRB4 ........................ 103

Figura $n^{\circ}$ 19: Configuração esquemática da trincheira TRB5 ......................... 106

Figura $n^{\circ}$ 20: Configuração esquenática da trincheira TRB6........................... 109

Figura $n^{\circ}$ 21: Mapa da estrutura pluvial de Mato Grosso .................................. 122

Figura $n^{\circ}$ 22: Sistemas atmosféricos na estação seca. ................................... 124

Figura $n^{\circ} 23$ : Sistemas atmosféricos na estação chuvosa .............................. 127

Figura $n^{\circ}$ 24: Nível freático na topossequência A......................................... 151

Figura $\mathrm{n}^{\mathrm{o}}$ 25: Nível freático na topossequência $\mathrm{B}$........................................ 151

Figura n ${ }^{\circ}$ 26: Carta foto-interpretativa da saturação dos solos . ...................... 152 


\section{ÍNDICE DAS FOTOGRAFIAS}

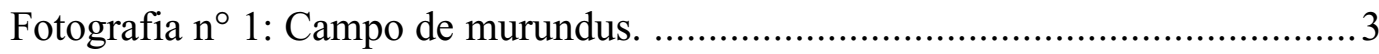

Fotografia n..$^{\circ}$ 2: Microrrelevo destruído por escavação de tatus..........................56

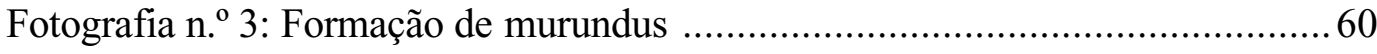

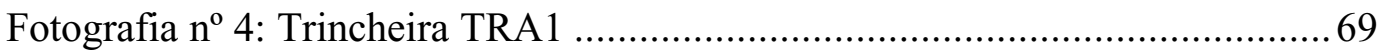

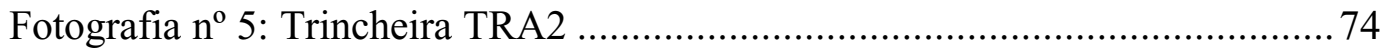

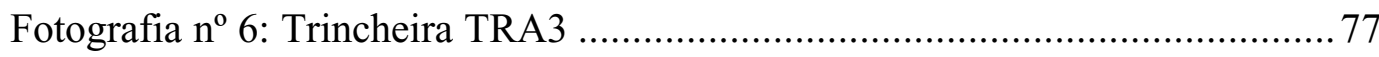

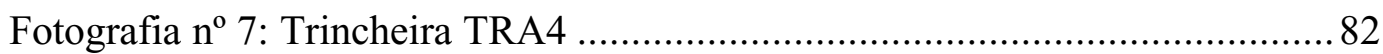

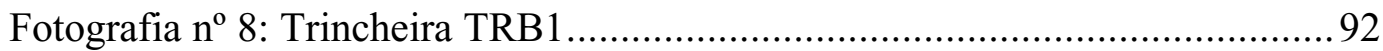

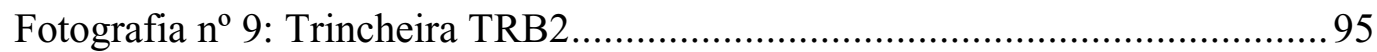

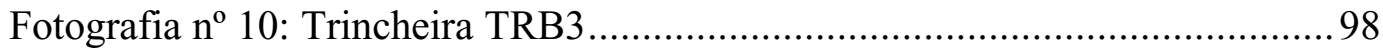

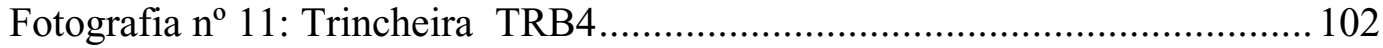

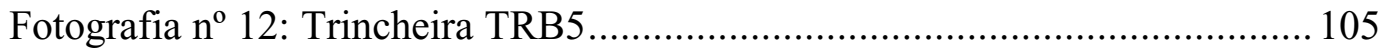

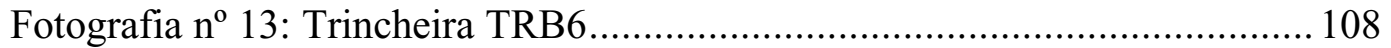




\section{ÍNDICE DOS GRÁFICOS}

Gráfico $n^{\circ} 1$ : Balanço hídrico 40

Gráfico nº 2: Pluviometria mensal de 1986 a 2000

Gráfico n ${ }^{\text {o } 3: ~ P l u v i o m e t r i a ~ m e n s a l ~ t o t a l ~ d e ~ j a n e i r o ~} 2000$ a janeiro 2001 .. 134

Gráfico $n^{\circ}$ 4: Comparação entre precipitação x piezômetro $\mathrm{P} 1$ 137

Gráfico $n^{\circ}$ 5: Comparação entre precipitação x piezômetro $\mathrm{P} 2$ 138

Gráfico $\mathrm{n}^{\mathrm{o}}$ 6: Comparação entre precipitação x piezômetro P3 139

Gráfico $n^{\circ}$ 7: Comparação entre precipitação x piezômetro $\mathrm{P} 4$ 140

Gráfico $\mathrm{n}^{\mathrm{o}}$ 8: Comparação entre precipitação x piezômetro P5 144

Gráfico $n^{\circ}$ 9: Comparação entre precipitação x piezômetro P6 145

Gráfico $n^{\circ}$ 10: Comparação entre precipitação x piezômetro P7 146

Gráfico $\mathrm{n}^{\circ}$ 11: Comparação entre precipitação x piezômetro P8 147 


\section{ÍNDICE DOS QUADROS}

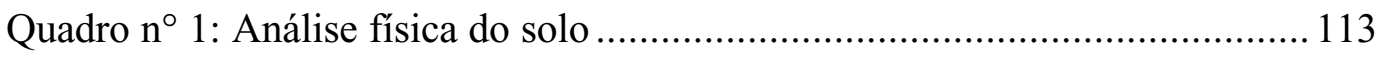

Quadro $\mathrm{n}^{\circ} 2$ : Análise granulométrica da areia ........................................... 114

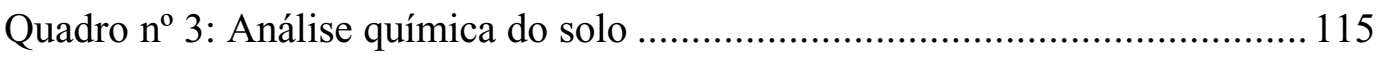

Quadro $n^{\circ} 4$ : Cálculos das determinações analíticas ....................................... 116

Quadro $^{\circ}$ 5: Dados pluviométricos do município de Sorriso em mm ............... 129

Quadro nº 6: Pluviosidade em Sorriso durante o ano 2000 ............................ 132

Quadro $n^{\mathrm{o}}$ 7: Pluviosidade na fazenda São Fidel....................................................... 133

Quadro no 8: Pluviometria na circunvizinhança de Sorriso em 1977................ 135

Quadro $n^{\circ}$ 9: Medida do nível da água do solo ............................................. 141 


\section{INTRODUÇÃ̃O}

A Amazônia matogrossense constitui-se, hoje, em uma grande fronteira agrícola em expansão, que vem sendo colonizada a partir da década de 70, principalmente por brasileiros vindos do sul do País. A rápida ocupação deste território vem se realizando às custas de grandes desmatamentos da Floresta Amazônica, abrindo espaço para a agricultura, a pecuária e a urbanização. Algumas cidades desta região já contam com uma população de 60.000 habitantes, em menos de duas décadas de emancipação política.

Neste processo de ocupação, as transformações da paisagem vão além da perda da biodiversidade e das alterações climáticas, podendo modificar a própria estrutura dos solos. As conseqüências, em termos de compactação e erosão dos solos, assoreamento dos cursos d'água e comprometimento dos recursos hídricos, são amplamente observáveis, mas o seu desenvolvimento e conseqüências econômico-ambientais são ainda desconhecidas.

Fato notável é o rebaixamento do nível freático de campos de murundus, extensos campos brejosos com microrrelevos, por meio da escavação de uma rede de canais, visando ampliar os espaços de agricultura, como vem ocorrendo em vários municípios da região, a exemplo de Sorriso e Lucas do Rio Verde, situados na região norte do Estado, no Planalto dos Parecis, bem como em municípios de outros planaltos de Mato Grosso. 
Esta forma de ocupação e manejo do solo vem se constituindo cada vez mais em uma questão polêmica junto aos diversos setores atuantes na região, especialmente no que diz respeito às relações custo/benefício ambiental, ao tempo de duração do benefício, à reversibilidade das transformações negativas ou impactos negativos e dos possíveis impactos ecológicos que podem se manifestar ao nível da estrutura pedológica, mudanças climáticas, recursos hídricos, conservação da biodiversidade e, consequentemente, ao desenvolvimento sustentável.

\subsection{Fundamentos teóricos e metodológicos da pesquisa}

No estado de Mato Grosso, especialmente no Planalto dos Parecis, os microrrelevos em campos brejosos, também conhecidos por campos de murundus, constituem áreas extensas onde predominam PLINTOSSOLOS ARGILÚVICOS e nascem importantes rios da bacia Amazônica.

Os campos de murundus referidos nesta tese, caracterizam-se por constituírem extensas áreas brejosas ou alagadiças com gramíneas, freqüentemente com ilhas esparsas de cerrado, nucleados por cupins, similares aos covoais, também denominados de monchões e cocorutos, importantes sob o ponto de vista da ecologia, pois apresentam indícios da evolução do gradiente vegetacional do cerrado, nítidas relações entre fauna e flora, íntima ligação com a perenização das nascentes e dos cursos d'água e interdependência com o regime climático (Mathews, 1977; Pullan, 1979; Penteado-Orellana, 1980; Abreu, 1981; Embrapa, 1982; Funchi, 1985; Eintein, 1985; Furley, 1985-1986; Araújo Neto, 1986; Araújo Neto, Furley \& Johnson, 1986; Oliveira-Filho, 1988; Correa, 1989 e Oliveira-Filho \& Furley, 1990), conforme ilustra a fotografia $n^{\circ} 1$. 


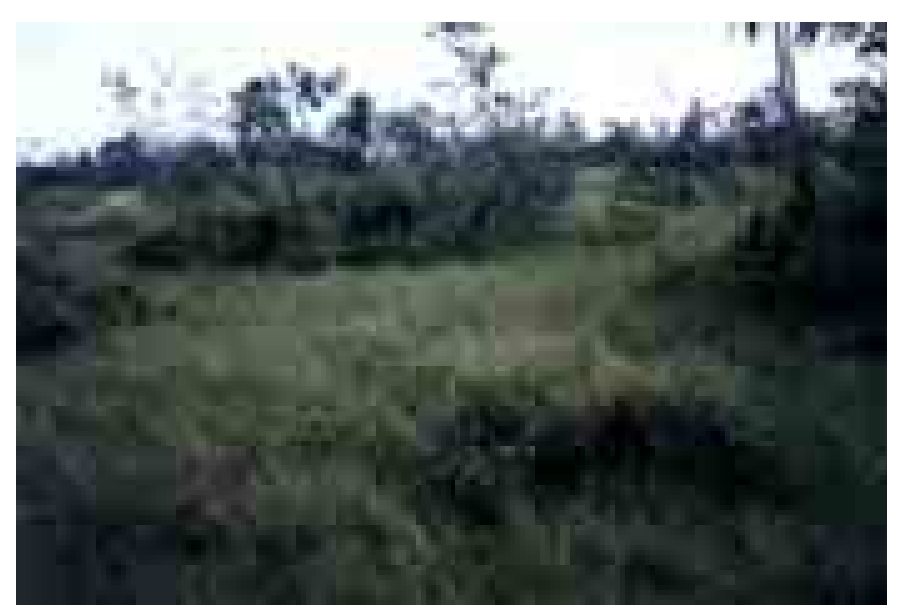

Fotografia $n^{\circ}$ 1. Campo de murundus. (Castro-Junior,2001)

Os fenômenos de hidromorfismo foram estudados por alguns pesquisadores como Vizier (1983) em solos de regiões tropicais com estações contrastantes, em termos da dinâmica do ferro e da diferenciação dos perfis, contudo a dinâmica hídrica destes solos não se encontra ainda suficientemente compreendida.

O estudo dos campos de murundus, em termos da dinâmica hídrica, da estrutura pedológica, do regime pluviométrico, do comportamento piezométrico, da localização das áreas de ocorrência, das relações com a rede hidrográfica, bem como a função que desempenham dentro do ecossistema, adquire grande importância para as regiões tropicais, especialmente para o estado de Mato Grosso, na transição do cerrado com a floresta amazônica, no sentido de estabelecer os limites ambientais do desenvolvimento sócio-econômico (Santos, Prandini e Oliveira, 1990).

Um estudo pedológico de detalhe voltado à dinâmica hídrica, não pode estar restrito apenas ao registro cartográfico da ocorrência quando se pretende compreender o comportamento e funcionamento dos solos. Para tanto, é importante valorizar o seu estudo em pequenas bacias hidrográficas, em interflúvios com suas vertentes, na medida em que os fluxos hídricos obedecem a trajetórias internas e externas aos solos, convergentes para o canal central, que desempenha o papel de nível de base regulador do comportamento hidrológico superficial. 
Para o reconhecimento dos fluxos hídricos em termos de direções e intensidades e partindo-se de setores representativos das paisagens, cuja escolha dá-se em função da convergência espacial/temporal de fatores do meio, foi necessário realizar o levantamento do arranjo dos horizontes pedológicos tanto no sentido vertical, através dos perfis de solo expostos em trincheiras, como lateral, pela restituição, em projeção, da continuidade dos horizontes, a partir e entre os perfis verticais alinhados ao longo de transetos ou seções topográficas.

Características físicas, tais como a cor, a textura, a estrutura, a consistência e a densidade, bem como as características físico-hídricas como a estabilidade dos agregados, a porosidade, a condutividade hidráulica, retenção de água, expansão/retração, etc., e as características geoquímicas e mineralógicas como a acidez, o potencial redox, o tipo de argila, o complexo sortivo, o teor em óxidos, em carbono, em nitrogênio, etc., são muito importantes para a dedução das propriedades dos solos, que, quando obtidas em solos equivalentes sob condições naturais e sob condições manejadas, e ao longo desses transetos, permitem, não só um diagnóstico relativo às mudanças sofridas em conseqüência do manejo (impacto), como também um prognóstico relativo às tendências evolutivas observadas, como já constatado em numerosos trabalhos no todo ou em parte (Salomão, 1994; Furian, 1993; Cunha, 1956, dentre outros).

Portanto, uma análise espacial feita com base em documentação cartográfica existente, compatibilizadas as escalas, permite a obtenção da localização, delimitação e identificação dos prováveis fatores associados à ocorrência destes campos de murundus. Uma eventual tipologia ou hierarquia permitiu a seleção daquela que seja representativa. A contextualização pedobiogeoclimática em termos de condicionamento de processos biogeodinâmicos regionais e locais assim como a corroboração das interpretações prognósticas para fins de avaliação dos impactos 
ambientais.

Análises climáticas regionais muito amplas foram feitas por Nimer \& Brandão (1983), outros estudos de fluxos de energia e hidrologia do solo, enfocando as interações solo/planta/atmosfera foram realizados em área da Floresta Amazônica e áreas desmatadas de entorno por Wright et al , (1992) e Gash et al, (1996). Entretanto, estudos dessa natureza em campos de murundus, que são típicas do cerrado do Brasil central, bem como na transição para a Floresta Amazônia, são insuficientes para entender os processos que caracterizam os topo e microclimas de cada realidade local.

O desenvolvimento de modelos mais acurados de previsão de tempo e de clima, bem como do conteúdo de água no solo permitirá melhores estimativas de água no solo para subsidiar as tomadas de decisões relacionadas com o planejamento do uso do solo, como as atividades agrícolas, por exemplo.

Para melhor compreender o que foi exposto, é necessário considerar o que segue, a respeito das técnicas de levantamento e caraterização físico hídrica dos solos, numa perspectiva da lateralidade dos horizontes e de seu funcionamento.

Os solos foram considerados, desde as observações iniciais feitas por Dokouchaev (1887, in Bocquier 1984), fundador da ciência do solo, como formados a partir dos efeitos conjugados de fatores ambientais definidos como substrato, relevo, clima e organismos, em especial vegetação, ao longo do tempo (Jenny, 1941). Foram, desde então, observados por sua morfologia, visível em cortes verticais denominados perfis de solo em campo, caracterizada por uma sucessão também vertical de horizontes cuja nomenclatura adotou as letras $\mathrm{A}, \mathrm{B}$ e $\mathrm{C}$, mais tarde foi adicionada de números em minúsculo, indicando subdivisões internas de horizontes, e também de letras, normalmente minúsculas, indicando características 
específicas, como texturas, certas concentrações de constituintes, etc. Essa nomenclatura tem servido de diagnóstico tipológico-classificatório e, freqüentemente, indica processos e mecanismos ligados à sua gênese (Douchaufour, 1997).

Entretanto, Milne (1938, in Bocquier op. cit.) já observara variações laterais entre solos, ao longo da topografia, sobre um mesmo substrato rochoso, com relações genéticas entre si, e que ele denominara de catena. Delvigne (1962), inspirado nesta interpretação, considerou os processos de formação dos solos como ligados a mecanismos de perda de matéria no topo, de transferência por toda a vertente e de acumulação no sopé, independentemente do substrato, promovidos pela circulação de soluções induzidas pela topografia.

Nos anos 70, vários pesquisadores trabalhando em regiões tropicais africanas, mais tarde na Guiana Francesa, e, mais recentemente, desde os anos 80, no Brasil, avançaram muito nessa interpretação, aperfeiçoando as técnicas de descrição e representação dessas sucessões laterais, valorizando bastante os fluxos hídricos verticais e/ou laterais, deduzidos de feições pedológicas produzidas pela alteração e pedogênese, ligadas a perda, transformação e acumulação de constituintes, tanto em solução como em suspensão. Aprimorou-se assim o estudo em topossequências, através da observação de perfis de solos alinhados ao longo do eixo principal de seções topográficas ou transetos, dispostos do topo à base de interflúvios e que permitem a reconstituição em continuum, da geometria dos horizontes (Ruellan, 1970; Bocquier, 1973; Boulet, 1976 e 1998; Chauvel, 1977; Humbel,1978; Queiroz Neto, 1988, dentre outros).

Esses procedimentos foram sistematizados por Boulet e sua equipe (Boulet et al., 1982), realizando esforços de aplicação agronômica, visando maior e melhor manejo do solo e da água, no interior de microbacias e inclusive de parcelas experimentais, na Guiana Francesa, em grande parte 
constantes do relatório ECEREX (1989), bem como de generalização cartográfica para escalas menores (no caso 1:350.000), visando a representação, não de unidades de mapeamento de solos unitariamente considerados, como se faz tradicionalmente, mas de conjuntos caracterizados pelas sucessões laterais (Boulet et al, 1988), que mais tarde foram denominadas de sistemas pedológicos (Soubiés e Chauvel, 1984). Alguns desses sistemas permitiram sua separação em sistemas pedológicos em equilíbrio e em desequilíbrio atual (Boulet et al, 1984 e 1992).

Os sistemas em desequilíbrio atual são aqueles que apresentam um solo inicial que foi truncado por erosão ou que, por causas tectônicas ou de aprofundamento do nível de base devido a mudanças climáticas, freqüentemente quaternárias, está sendo transformado em outro, compatível com as novas condições ecológico-ambientais atuais. Essa nova pedogênese ocupa normalmente a vertente esculturada pela dissecação e/ou pela própria pedogênese, podendo estender-se desde o seu terço superior, se estiver bem avançada, ou ficar restrita ao setor jusante, onde é sucedida por solos ligados à hidromorfia. A instalação desse novo solo se dá em conseqüência da mobilização tanto vertical como lateral dos constituintes eluviados por lixiviação e/ou lessivagem do solo inicial, que resta cada vez mais restrito ao topo, por ação de fluxos hídricos igualmente cada vez mais laterais, à medida que a vertente vai sendo esculturada, por rebaixamento e, não raro, por convexização, quando o clima atual é do tipo equatorial ou tropical úmido, freqüentemente com estações contrastadas.

Estudos mais recentes realizados no Brasil, desde o início dos anos 80, tem revelado a presença repetitiva de sistemas desse tipo, mostrando que a umidificação progressiva do clima tropical quaternário tem sido a causa mais comum dessa transformação lateral, tanto em relevos colinosos amplos e suaves como em relevos mais declivosos, com ou sem rupturas de declive em meia encosta (Queiroz Neto et al, 1881; Castro, 1990; Salomão, 
1994; Santos, 1995; Cunha,1996; Oliveira, 1997; Dias Ferreira, 1997, dentre outros).

Esses estudos mostraram, por um lado, que os indícios da transformação são bastante superficiais, diferenciando progressivamente o horizonte A dos solos iniciais já no terço superior, e visíveis tanto em campo como através do exame de lâminas delgadas, onde as microestruturas revelam remoção de finos, normalmente da fração argila, promovendo a concentração residual da fração areia. Por outro lado, mostraram também que há um aumento vertical e lateral, crescente para jusante, da fração argila no horizonte subsuperficial, que promove a instalação de um novo sistema poroso com propriedades hídricas cada vez mais contrastadas em relação aos horizontes de montante.

A circulação hídrica lateral, nessa situação, permite até mesmo a instalação de um lençol suspenso, com exfiltração (piping), no contato entre o horizonte superficial cada vez mais arenoso e o subsuperficial cada vez mais argiloso. As mudanças texturais incorrem em mudanças estruturais e de porosidade e esta, em conseqüência, passa a desempenhar paulatinamente o papel de motor da circulação (Castro \& Curmi, 1987, 1993; Salomão, 1994). A porosidade cavitária torna-se cada vez maior, mais interconectada e mais e mais coalescente nesse contato (Castro \& Curmi, 1993) e essa dinâmica acaba por justificar porque texturas similares apresentam comportamento de condutividade hidráulica e retenção hídrica fortemente diferenciadas entre os horizontes iniciais, em geral do tipo latossólico e os novos horizontes subsuperficias, em geral do tipo Bt (Salomão, 1994).

$\mathrm{O}$ volume de água que drena para jusante, produto inclusive da junção do lençol freático e do suspenso é cada vez mais importante e acaba por gerar o aparecimento dos solos hidromorfisados do terço inferior, além de bossas e rebaixamentos lineares dos terrenos, que podem favorecer a 
instalação de processos erosivos do tipo ravinas e boçorocas (Salomão, 1994; Cunha, 1996; Oliveira et al, 1998), por facilitarem a concentração do escoamento superficial das águas pluviais.

Em áreas de relevos tabuliformes ou monoclinais suaves, diferentemente das regiões supra citadas, é comum o aparecimento de zonas hidromórficas nos topos ou próximo às bordas, cujas características peculiares de cada uma levam a denominações locais ou regionais como veredas, covoais de campo de murundus (Schneider, 1997), cujas origens são polêmicas (Oliveira Filho et al, 1992; Dinis Filho et al, 1989, dentre outros), e comumente alojam as cabeceiras de drenagens. Mas, podem conter transformações laterais que podem associar-se a processos similares ao descrito acima, em relevos muito suaves, mas onde, por razões ainda desconhecidas, a energia da dissecação não foi tão eficaz como naquelas. Tais zonas poderiam, hipotéticamente, surgir associadas a condicionamentos lito-estruturais indutores de setores depressionários nos terrenos, de origem geoquímica por dissolução em profundidade, facilitada por litologias mais suscetíveis ou por fraturamentos, mas que poderiam revelar outrossim mecanismos de instabilização e transformação de solos iniciais, situados mais à montante, como exposto anteriormente.

Entretanto, a presença de horizontes orgânicos superficiais ou enterrados, de natureza turfosa, passíveis de datação, estudados em depressões geomorfologicamente mais evoluídas devido ao maior rebaixamento topográfico, tem permitido constatar, além da idade quaternária recente, que haveria tempo suficiente para sua formação em condições de saturação, paralelamente à subsidência de natureza geoquímica em profundidade a ela associada (Filizola, 1995; Piló, 1998), mas lenta o bastante e não drenante o suficiente para destruir a camada turfosa, embora deformando-a ou até soterrando-a por sedimentos oriundos de erosão de montante. 
A natureza da maioria dessas transformações mostra freqüentemente que o ferro desempenha papel fundamental devido à participação nos fenômenos de lixiviação, dissociação ferro/argila e óxido-redução (Chauvel, 1977; Lepsch \& Buol, 1977; ISS, 1985; Castro \& Curmi, 1987; Castro, 1990, dentre outros). A hidromorfia sensu strito, ligada a fenômenos de gleização, universalmente conhecidos, praticamente não foram estudados nessas áreas, as quais já começam a ser manejadas, como se deu em áreas similares (covoais), mas sem o devido conhecimento de seu comportamento e funcionamento, nem anterior e muito menos posterior à sua ocupação, do ponto de vista das transformações pedológicas induzidas e impactos decorrentes.

Pode-se supor que a drenagem desses terrenos, possa diminuir ou instabilizar sensivelmente o processo hidromórfico dos solos aí presentes e até induzir novos processos pedogenéticos não hidromórficos, mais oxidante.

As metodologias de pesquisa pedológica, empregadas nestes estudos, tem privilegiado a observação morfológica detalhada do continuum do manto pedológico, caracterizar a hierarquia e cronologia das estruturas presentes, bem como os eventos de alteração e pedogênese sucessivos e, por outro, para caracterizar o estágio ou grau de desenvolvimento dos sistemas pedológicos, com o intuito de avaliar os seus comportamentos e funcionamentos atuais numa dada paisagem, o que pode ser de suma importância para o manejo dos solos e da água (Queiroz Neto, 1988).

Estudos empregando essas metodologias de campo e laboratório ainda são poucos e os que foram feitos são pouco divulgados por estarem contidos em teses relativamente recentes no Brasil, e na maioria, desenvolvidos em outros ecossistemas. Para essas zonas hidromórficas, com exceção dos estudos relativamente pioneiros e recentes Schneider (1997) e Lima (1997) realizados em áreas de cerrado em Minas Gerais, que 
revelaram processos de transformação lateral de cobertura latossólica, não foi realizado nenhum estudo comparativo entre zonas não manejadas por atividade agrícola, não se conhecendo praticamente nada a esse respeito.

É necessário, portanto, conhecer melhor tanto o sistema pedológico em condições naturais como manejadas, no caso, por drenagem, para cultivo intensivo, como o que vem acontecendo nessas zonas hidromorfisadas do norte de Mato Grosso, cujas conseqüências são completamente desconhecidas.

Até recentemente, no estado de Mato Grosso, evitou-se a ocupação e manejo de áreas com estas características de hidromorfismo, por possuírem o nível freático na superfície do terreno durante vários meses do ano, características que impõem sérias limitações ao uso, especialmente por ocasião da colheita, no final do período das águas, quando os solos encontram-se supersaturados. Contudo, visando maior produção agrícola, estas áreas, depois de drenadas, vem sendo cada vez mais utilizadas, desconhecendo-se quais as conseqüências que esta interferência trará ao ecossistema.

\subsection{Objetivos}

Os objetivos desta pesquisa foram classificados em dois níveis: objetivo geral e objetivos específicos.

\subsubsection{Objetivo Geral}

Conhecer a estrutura pedológica e a dinâmica da água em campos de murundus na bacia do médio no Teles Pires, na transição do cerrado para a floresta amazônica, área de ecótono ou tensão ecológica, no Planalto dos Parecis, estado de Mato Grosso, e suas relações com as variações 
pluviométricas, visando a compreensão acerca do funcionamento hídrico destas paisagens e de seus solos.

\subsubsection{Objetivos específicos}

Para alcançar o objetivo geral, formulou-se uma série de objetivos específicos, para os quais foram previstas atividades ordenadas e interrelacionadas, priorizando duas áreas-teste, uma com solos não drenados (natural) e outra com solos drenados (cultivados). Dessa forma, pretende-se:

1.2.2.1. Caracterizar o substrato geológico, solo, relevo, vegetação, clima e uso do solo, onde se inserem os campos de murundus para uma contextualização inicial do meio físico, em escalas médias a grandes, através de compilação de documentos existentes e observações de campo;

1.2.2.2. Reconhecer as ocorrências dos campos de murundus e estudar duas áreas-teste, uma com solos drenados e cultivados, e outra com solos não-drenados com vegetação nativa, com vistas à seleção de áreas representativas que serão delimitadas a nível de bacia hidrográfica;

1.2.2.3. Caracterizar as condições climáticas da área objeto da pesquisa por meio de dados climatológicos de superfície disponíveis (séries históricas);

1.2.2.4. Identificar as coberturas pedológicas;

1.2.2.5. Medir as variações do nível freático em um ano hidrológico completo por meio de piezômetros, nas duas topossequencias;

1.2.2.6. Indicar sugestões ao uso e manejo adequados aos campos de murundus, a partir dos resultados obtidos.

\subsection{Metodologia}


Uma seqüência de quatro estágios de trabalho, orientou o desenvolvimento desta pesquisa. As atividades principais definem os procedimentos e técnicas utilizadas.

\subsubsection{Compartimentação morfopedológica}

As atividades desenvolvidas neste estágio foram direcionadas para a compartimentação do meio físico, levando-se em conta principalmente as características do substrato geológico, do relevo e dos solos, utilizando-se dados disponíveis de reconhecimento de campo, correspondendo ao primeiro nível de tratamento metodológico, destacando-se os seguintes procedimentos:

\subsubsection{Levantamento e compilação de documentação cartográfica}

Foram levantados e analisados os dados disponíveis de interesse ao entendimento do meio físico em termos de geologia, relevo, solos, vegetação e clima, e trabalhos existentes que tratam do problema, bem como fotos aéreas, imagens de satélite e cartas topográficas em diferentes escalas.

1.3.1.2. Levantamento e delimitação de ocorrências de solos hidromórficos

Esta identificação foi realizada primeiramente por meio de interpretação de fotografias aéreas na escala de 1:60.000, da USAF, 1966, e imagens Landsat em escala 1:100.000. A data da tomada das fotos favorece o trabalho, visto que naquela época não havia qualquer forma de uso ou ocupação do solo, portanto a vegetação pode ser vista em sua forma nativa e os campos de murundus apresentam-se com um padrão textural distinto de outras paisagens. 


\subsubsection{Compartimentação morfopedológica}

As observações de campo, completadas por fotointerpretação, permitiram a delimitação mais precisa dos compartimentos morfopedológicos.

1.3.1.4. Elaboração de mapa de uso do solo, em escala 1:75.000

Com base em imagens de satélite e checagem em campo foi elaborado o mapa de uso do solo.

\subsubsection{Caracterização das coberturas pedológicas}

As atividades desenvolvidas no estágio anterior, permitiram a escolha de uma microbacia representativa para a caracterização detalhada da cobertura pedológica em topossequências, e definição do sistema pedológico, tido como uma porção da cobertura pedológica que, por suas estutruras e por suas dinâmicas, constitui uma unidade, dentro da abordagem proposta pela análise estrutural (Ruellan \& Dosso, 1993).

\subsubsection{Escolha de topossequências representativas}

A compartimentação morfopedológica juntamente com o mapa de uso do solo constituiu a base para a escolha de eixos para levantamento de topossequências representativas. O primeiro por indicar os compartimentos com solos hidromórficos, e o segundo, por indicar as áreas drenadas e as não drenadas. Foram selecionadas duas topossequências, uma em uma vertente com solos drenados e outra vetente, nas mesma microbacia, com solos hidromórficos não drenados, para estudos comparativos.

\subsubsection{Levantamento e representação das topossequências}

Estes levantamentos foram desenvolvidos segundo um roteiro de atividades, cuja seqüência é sintetizada a seguir: 
a) Escolha da microbacia a ser investigada, por meio de imagens de satélite e reconhecimento de campo;

b) Investigação de subsuperficie através de sondagem a trado, ao longo da transeção escolhida para a caracterização morfológica dos principais horizontes pedológicos e suas relações espaciais e laterais ao longo da vertente. Levantamento expedito do perfil topográfico da transeção, com utilização de clinômetro, metro e trena;

c) Complementação das atividades de campo com sondagens adicionais para identificar e situar melhor as transições laterais entre os horizontes pedológicos;

d) Abertura de trincheiras em pontos-chave para descrição morfológica detalhada dos horizontes pedológicos, suas transições verticais e laterais e coleta de amostras deformadas para análises laboratoriais dos horizontes-guia;

e) Representação gráfica final das topossequências.

\subsubsection{Análises de laboratório}

As análises das amostras deformadas permitiram a detrerminação de análises físicas e químicas.

\subsubsection{Comportamento hídrico das vertentes e definição do sistema} pedológico

O estudo de topossequências permitiu identificar as características morfológicas relacionadas ao comportamento hídrico dos solos para deduzir as direções dos fluxos da água infiltrada e escoada superficial e subsuperficialmente (Salomão, 1994) como das conseqüências destes nos próprios solos. 


\subsubsection{Atributos físico-hídricos das coberturas pedológicas}

Dentre os principais atributos do solo que condicionam o movimento da água, destacam-se a textura, a estrutura, a geometria.

A textura, a estrutura e a geometria e arranjo do sistema poroso são características que constituem a matriz do solo, fazendo parte de sua organização. Foram estudados no campo, principalmente através da descrição minuciosa de trincheiras, e em laboratório, por meio de análise granulométrica.

\subsubsection{Comportamento do nível freático}

A caracterização do comportamento das águas do lençol freático foi feita através da análise da densidade de fluxo e do gradiente hidráulico em sistemas de aqüífero livre. A análise da densidade de fluxo e do gradiente hidráulico foi a partir do monitoramento do nível freático em piezômetros instalados na vertente no período de 12 meses.

$\mathrm{O}$ resultado das leituras piezométricas foi analisado em relação às precipitações observadas em igual período.

\subsubsection{Caracterização do clima}

Para a caracterização climatológica foram utilizados dados da série histórica disponível na área referente ao período de 1986 até 2001, coletados em estações convencionais mantidas pela Secretaria Municipal de Agricultura e Meio Ambiente e Sorriso. A análise da homogeneidade destas séries foi feita utilizando-se análise estatística não-paramétrica.

As séries climatológicas (valores normais) serviram de fundamento para a avaliação do balanço hídrico anual da região, pelo método de Thornthwaite-Matter (1955), assim como o comportamento das variáveis do balanço hídrico: precipitação, evapotranspiração potencial, real, deficiência 
e excedente hídrico.

\subsubsection{Regionalização dos campos de murundus}

Com base nos padrões (formas, textura, tom de cinza) obtidos nas fotos aéreas (USAF, 1966) para as paisagens onde se encontram os campos de murundus. A seguir, esses indicadores foram extrapolados para a bacia e obtidas as áreas similares. Com base no comportamento hídrico das áreasrepresentativas (drenada e não-drenada) foram adaptados os critérios interpretativos para as áreas similares.

\subsection{Caracterização regional da área de pesquisa}

A caracterização regional da área é feita a seguir, por meio da descrição geral dos aspectos relativos a localização e situação geográfica, geologia, geomorfologia, pedologia, climatologia, vegetação e uso e ocupação do solo

\subsubsection{Localização e Situação Geográfica}

A área de pesquisa localiza-se no estado de Mato Grosso, na unidade morfoescultural Planalto dos Parecis, que abrange aproximadamente 50\% da área do Estado, na bacia hidrográfica do médio rio Telles Pires, tributário do rio Amazonas em sua margem direita, ou seja, na parte meridional da Amazônia, conforme ilustra a figura n. ${ }^{\circ} 1$.

Localmente, a área localiza-se no município de Sorriso, distrito de Primaverinha, Fazenda São Fidel, Km 700 da BR 163, nas nascentes do Ribeirão Grande, afluente do rio Telles Pires, entre as coordenadas $55^{\circ} 55^{\prime}$ 19 ” W, $12^{\circ} 50^{\prime} 11^{\prime \prime} \mathrm{S}$ e $55^{\circ} 49^{\prime} 09^{\prime}$ ' W, $12^{\circ} 56^{\prime} 30^{\prime}$ ' S, conforme ilustra a figura.$^{\circ} 1$. 


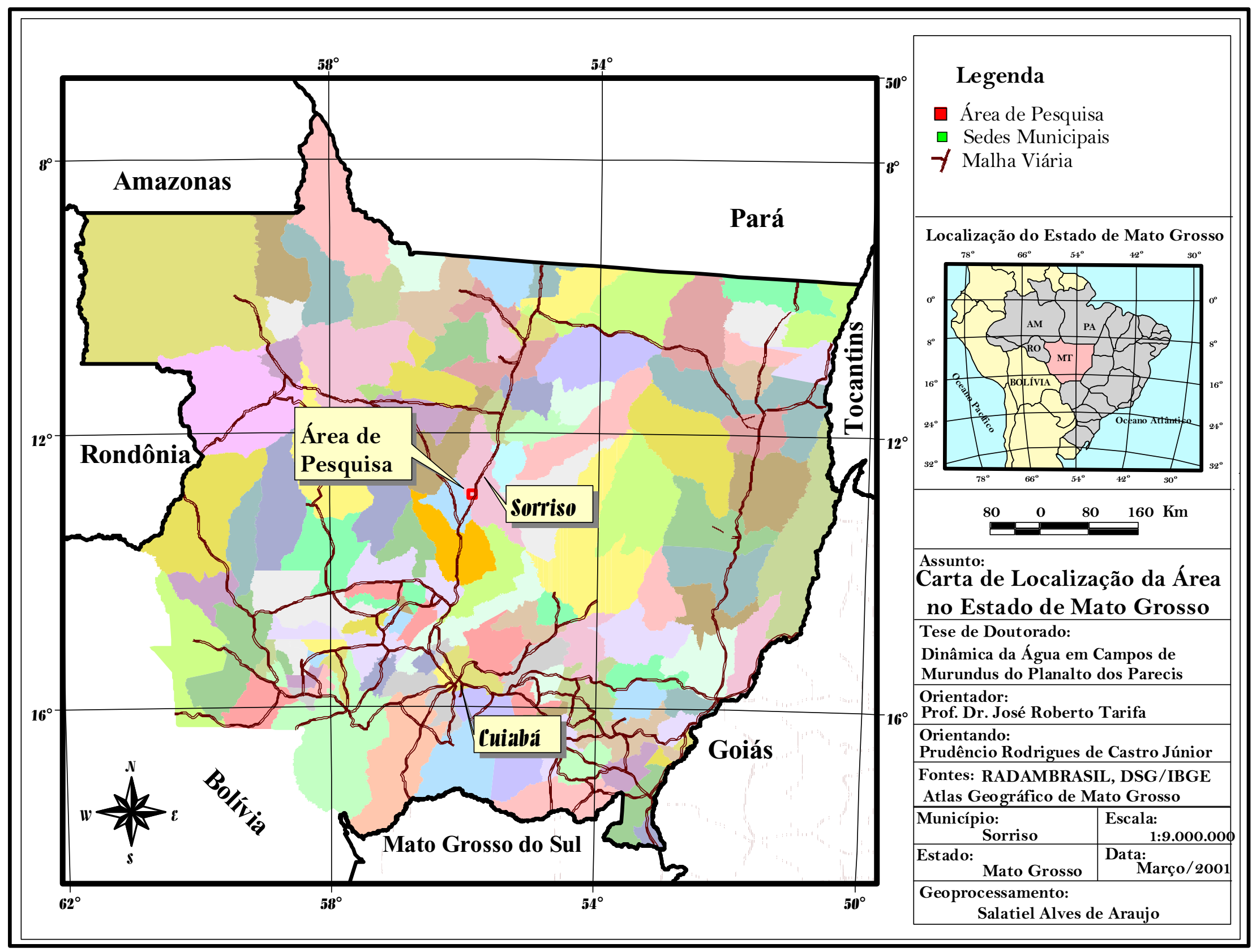

Localização da área no estado de Mato Grosso 


\subsubsection{Aspectos geológicos}

Esta pesquisa insere-se no âmbito dos sedimentos inconsolidados, areno-argilosos, de cores vermelhas, parcialmente laterizados, de idade terciária e quaternária, denominados por Cobertura Detrito-Laterítica (TQdl), conforme ilustra a figura $\mathrm{n}^{\circ} 2$.

\subsubsection{Cobertura Detrito-Laterítica (TQdl)}

A Cobertura Detrito-Laterítica representa no do estado de Mato Grosso, a unidade de maior expressão areal. Sua distribuição destaca-se em duas porções distintas (Radambrasil, 1981). A primeira localiza-se nas partes mais elevadas do Planalto, edificadas sobre a Chapada dos Parecis, em cotas altimétricas que oscilam entre 500 e $750 \mathrm{~m}$. O modelado do relevo é de superfícies planas, suavemente onduladas, com bordas escarpadas, normalmente posicionadas nas cabeceiras dos rios que drenam a norte para a Bacia Amazônica ou a sul para a Bacia Platina. A segunda ocorre na porção sudeste, recobrindo grande parte das rochas da Bacia do Paraná, ocupando aí, também, as partes mais elevadas, estendendo-se no sentido leste-oeste por uma extensão aproximada de $160 \mathrm{~km}$, com largura média de $50 \mathrm{~km}$, constituindo a Chapada dos Guimarães. Outra distribuição significativa destas coberturas ocorre sobre os metamorfitos do Grupo Cuiabá, em área restrita à borda leste da serra das Araras. As espessuras destas coberturas variam em média de 20 a $50 \mathrm{~m}$, medidos pelos pesquisadores do Projeto Radambrasil.

Esta cobertura constitui-se por uma zona inferior, com areias inconsolidadas, argilas, concreções ferruginosas e eventuais lentes conglomeráticas; uma zona média, com espessos lateritos ferruginosos; e uma zona superior, com solo argilo-arenoso, com concreções ferruginosas. A origem dessas formações superficiais é colúvio-aluvial, principalmente em ambientes com fluxos de águas pluviais concentradas do tipo enxurrada, 
onde havia uma alternância de climas úmido e semi-árido, que ocorreu durante o período Terciário Superior. A seqüência atinge algumas dezenas de metros de espessura. 


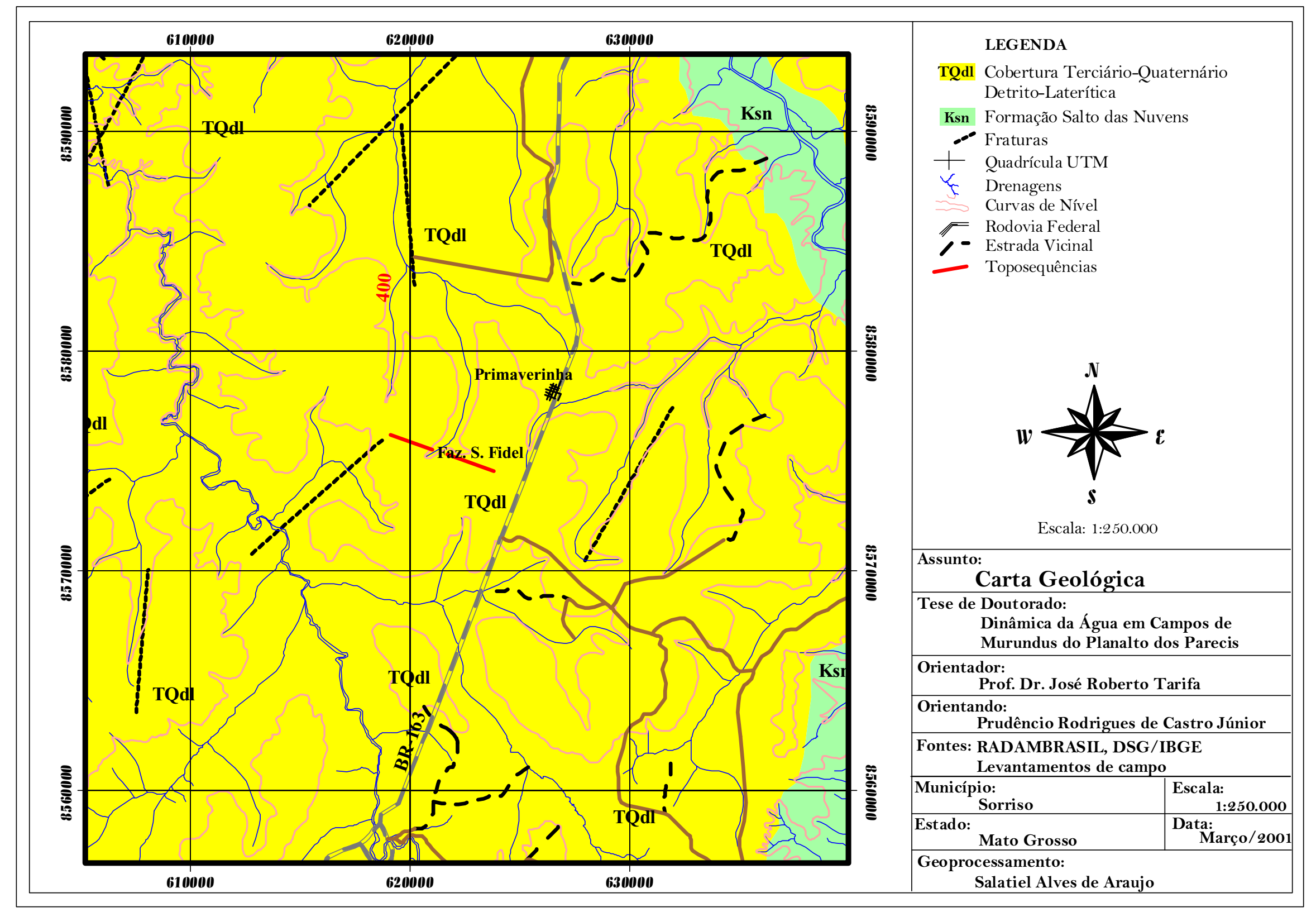

Mapa geológico 
Associada a uma vasta superfície de aplanamento, que recobre as rochas do Grupo Parecis, bem como a maioria das unidades da Bacia do Paraná e parte dos metamorfitos do Grupo Cuiabá, vem despertando interesse de estudiosos e pesquisadores, desde o final do século XIX até os dias atuais. Muitos dos trabalhos, de cunho científico, eram voltados apenas para reconhecimento da área, para implantação de vias de acesso, inventário dos recursos naturais e descrições de natureza geográfica.

Oliveira (1915) pela primeira vez chamou a atenção para o espesso solo vermelho ferruginoso, contendo horizontes ricos em cangas lateríticas, que recobriam a então Formação Parecis. A partir de Oliveira (op. cit.), vários estudos geológicos e geomorfológicos foram desenvolvidos principalmente sobre o Planalto dos Guimarães, que também é recoberto pela mesma unidade geológica, destacando-se entre eles Roxo (1937), Erichsen \& Löfgren (1940), Almeida (1948), Almeida (1954), Almeida (1959) e Beurlen (1959).

Beurlen (1959), ao admitir para aquela área um aplanamento pósTriássico, considerou a existência de uma capa sedimentar de origem fluvio-lacustre que a recobria, como correlativa aos sedimentos da Unidade Bauru, do Cretáceo Superior, na Bacia Sedimentar do Paraná.

No início dos anos 60, a Petrobrás iniciou uma série de trabalhos geológicos de semidetalhe, abarcando a borda noroeste da Bacia do Paraná, quando aquelas acumulações arenosas laterizadas e relacionadas no topo das chapadas tiveram sua inclusão em uma formação de cobertura. A primeira informação com este cunho é devida a Oliveira (1964), que denominou estes sedimentos de Formação Superior, caracterizando-os como arenitos avermelhados, argilosos, laterizados, com presença de concreções irregulares de canga ou corpos nodulares, restritos conglomerados, aos quais admitiu uma possível semelhança com depósitos aluvionares recentes. Descreveu, ainda, a destacada presença de um solo 
argiloso e impermeável, com cores vermelho escuras, mencionando seu endosso ao proposto por Beurlen (1959), correlacionando estes sedimentos em origem e idade com a Formação Bauru.

Corrêa \& Couto (1972), no Projeto Aluviões Diamantíferas de Mato Grosso, teceram considerações a respeito de uma intensa capa areno-laterítica ferruginosa, recobrindo rochas da antiga Formação Parecis. Ribeiro Filho et al (1975) comentaram a ocorrência de coberturas lateríticas e areno-lateríticas, na Chapada dos Parecis, bem como na Serra de Tapirapuã, Baixada Cuiabana e sobre a Formação Diamantino. Dividiram a cobertura em três horizontes, com uma espessura máxima de $40 \mathrm{~m}$, e comentaram que a unidade é produto de pediplanização terciária, hoje restrita a cotas entre 500 e $600 \mathrm{~m}$ de altitude.

Olivatti \& Ribeiro Filho (1976) concordaram com a maioria dos autores que se referiram a Coberturas Terciário-Quaternárias, acrescentando que tais coberturas são unidades edafoestratigráficas, ocorrendo sobre rochas arenosas, nos divisores de águas das Chapadas dos Parecis, dos Guimarães, e das serras Daniel, Formoso e Tapirapuã.

Oliveira et al (1979), quando da elaboração da Carta Geológica do Brasil ao Milionésimo da Folha SD.21 Cuiabá, estenderam as unidades terciárias Formações Araguaia e Cachoeirinha, às porções nordeste e sudeste da referida Folha. Cunha et al (1981), ao concluírem a Folha SC.22 Tocantins, do Projeto Radambrasil, suprimiram a Formação Araguaia no sentido de Barbosa et al (1966) e englobaram seus sedimentos às coberturas sedimentares terciário-quaternárias.

Os pesquisadores do Projeto Radambrasil, através das observações geológicas naquelas superfícies aplanadas constituídas dominantemente por solos argilo-arenosos, cor vermelha, ricos em concreções ferruginosas, que variam em concentrações e desenvolvimento, dependendo do seu horizonte 
de formação, com níveis também de argilas coloridas e areias inconsolidadas, que parecem tipificar perfeitamente coberturas lateríticas maturas e zonadas, concluíram que a melhor caracterização para aquelas coberturas está inserida no trabalho de Figueiredo et al (1974), no qual enquadraram com muita propriedade aquela superfície aplanada e laterizada no Terciário-Quaternário como uma unidade edafoestratigráfica.

Encontra-se esta Cobertura Detrito-Laterítica delimitada por ressaltos topográficos, realçados por atividades erosionais, com espessuras que oscilam entre 20 e $50 \mathrm{~m}$, onde é comum nestes escarpamentos a presença de camadas de material argilo-arenoso associado a crostas ferruginosas, que definem bancadas algo concrecionárias. Na superfície das chapadas arenosas, têm-se a implantacão de um relevo com suaves ondulações, drenagem de baixa freqüência, vegetação de cerrado ralo ou campo sujo, altitudes que variam entre 300 e $600 \mathrm{~m}$, com desenvolvimento de um latossolo espesso. $\mathrm{O}$ contato com as unidades sotopostas obedece à quebra de relevo, sendo na maioria das vezes inferido, devido ao intenso aporte de detritos que escorrem para as posições mais baixas. As cores mais características destes detritos são as vermelhas, marrons e amareladas, estando via de regra parcialmente laterizados.

Admitindo-se as coberturas detrito-lateríticas como unidade edafoestratigráfica, logicamente sua evolução estará ligada a processos pedogenéticos a partir de uma superfície aplanada em condições climáticas tipicamente tropical, devido à necessidade de alternância de estações secas e chuvosas. Dentro destes fatores, as condições ideais para a formação de coberturas lateríticas são encontradas em Maignie (1971 apud Figueiredo et $a l, 1974)$, destacando-se a necessidade de uma temperatura média anual em torno de $25^{\circ} \mathrm{C}$, no solo; o índice pluviométrico superior a $950 \mathrm{~mm}$ ao ano; a topografia plana com leve caimento entre $8 \%$ e $10 \%$ e o clima tropical úmido, Aw de Köppen, quente e úmido, com estações chuvosas e secas bem 
definidas. O fenômeno produz-se em toda a formação geológica permeável de topografia suborizontal percorrida por águas contendo ferro, condições que se verificam nos planaltos do estado de Mato Grosso.

\subsubsection{Geomorfologia}

Os campos de murundus estudados nesta pesquisa localizam-se no Planalto dos Parecis, que é a unidade morfoescultural de maior expressão espacial no estado de Mato Grosso, que estende-se de forma contínua no sentido oeste-leste, desde a fronteira do estado de Rondônia até o contato com a depressão do Araguaia, configurando o mais extenso divisor das Bacias Amazônica e Platina, (Radambrasil, 1981), conforme ilustra a figura n. ${ }^{\circ} 3$.

Esta unidade foi identificada e mapeada nas Folhas SC - 20 - Porto Velho, por Melo, Costa e Natali Filho (1978); SD.20-Guaporé, por Kux, Brasil e Franco (1979); SC.21 - Juruena, por Melo e Franco (1980) e SC.22 - Tocantins, por Ross e Santos (1980).

Ao norte limita-se com a depressão e os planaltos e serras residuais do norte de Mato Grosso; a leste com as escarpas da Serra do Roncador e depressão e planície do rio Araguaia; ao sul com as depressões interplanálticas de Paranatinga, Cuiabana e Alto Paraguai e o Planalto Jauru-Rio Branco. A oeste, adentra o estado de Rondônia e a sudoeste limita-se com a depressão do Guaporé.

Esta extensa unidade compreende várias unidades estratigráficas sobrepostas ao Complexo Xingu, englobando litologias sedimentares paleozóicas e mesozóicas e cobertura detrítico-laterítica neogênicas. Tratase de uma unidade relativamente elevada, com altitudes variando entre 300 e $800 \mathrm{~m}$ que, em função da diversidade litológica e altimétrica, foi subdividida em duas unidades morfoesculturais: a Chapada dos Parecis e o Planalto Dissecado dos Parecis. 


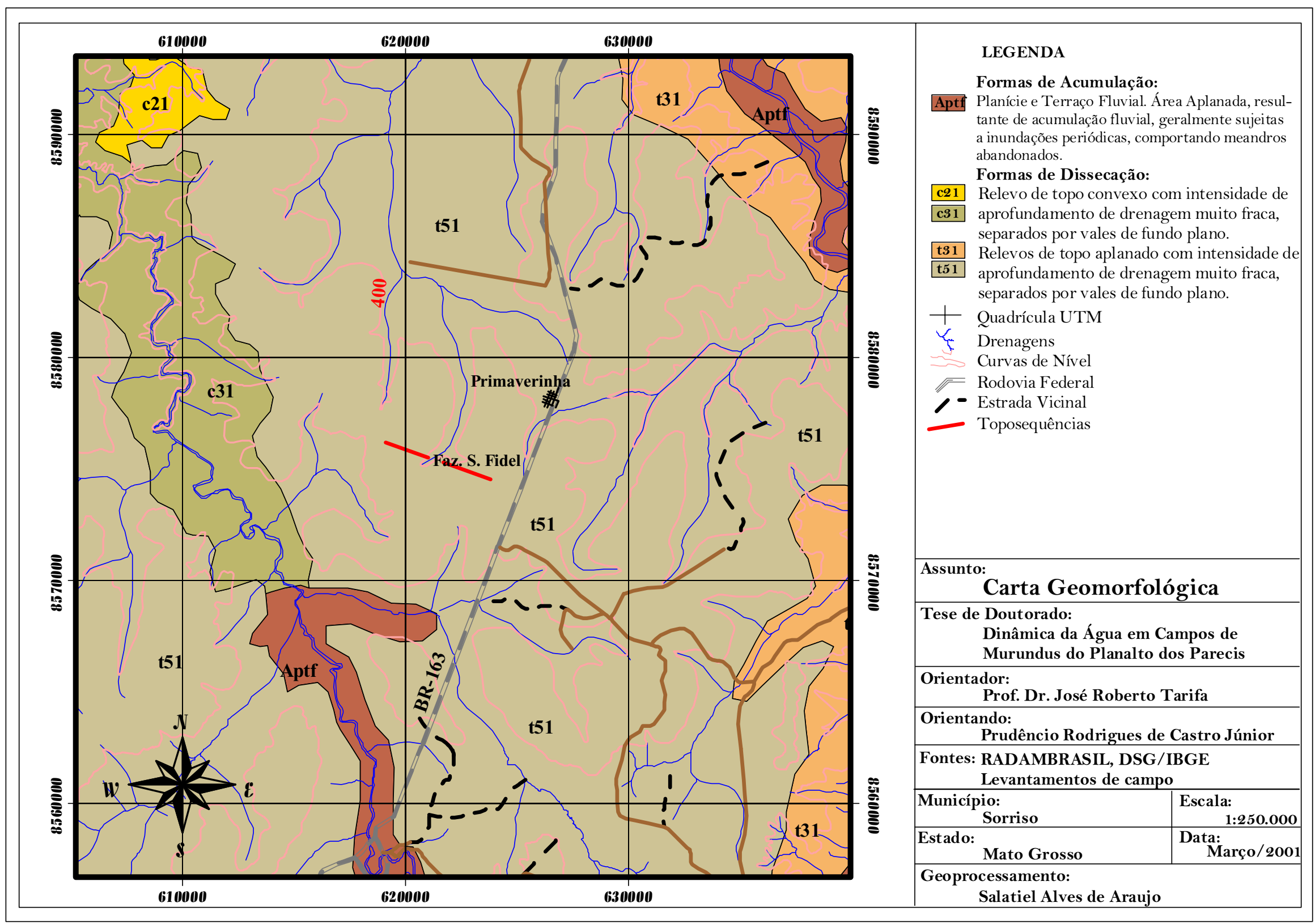

Mapa geomorfológico 
A área pesquisada situa-se inteiramente dentro dos limites do Planalto Dissecado dos Parecis, unidade que foi inicialmente identificada como Planalto Sedimentar dos Parecis (Melo, Costa e Natali-Filho, 1978). No mapeamento da SD.20 - Folha Guaporé (Kux, Brasil e Franco, 1979), identificou-se que esta unidade também apresentava litologias do cristalino do pré-Cambriano, de modo que a denominação adequada à nova situação passou a ser Planalto dos Parecis, titulação mantida nos mapeamentos da Folha SC.21 - Juruena (Melo e Franco, 1980) e da Folha SC.22 - Tocantins (Mamede, Ross e Santos, 1980).

Este trabalho, adota apenas a denominação de Planalto dos Parecis, para esta unidade geomorfológica que possui a maior extensão e expressão do estado de Mato Grosso, sendo um bloco relativamente homogêneo do ponto de vista altimétrico, com altitudes que variam de 400 a $350 \mathrm{~m}$ de leste para oeste, encontrando-se topograficamente rebaixado em relação à superfície da Chapada dos Parecis e que caracteriza-se pela homogeneidade das formas de relevo, predominantemente tabulares, com intensidade de aprofundamento de drenagem muito fraca (t51), ocorrendo também formas convexas (c31 e c21) e áreas aplanadas, em terraços e planícies fluviais (Aptf), relacionados aos principais rios, conforme ilustra a figura . $^{\circ} 4$.

\subsubsection{Solos}

$\mathrm{Na}$ área de pesquisa ocorrem solos do tipo LATOSSOLO VERMELHO AMARELO Distrófico (LVA), GLEISSOLOS HÁPLICOS Distróficos (GXbd), PLINTOSSOLOS ARGILÚVICOS Distrófico (FTd) e NEOSSOLOS QUARTZARÊMICOS Órticos (RQo), adaptados do Projeto

Radambrasil, 1981, de acordo com o atual Sistema Brasileiro de Classificação de Solos (Embrapa, 1999), conforme ilustra a figura $\mathrm{n}^{\circ} 4$. 


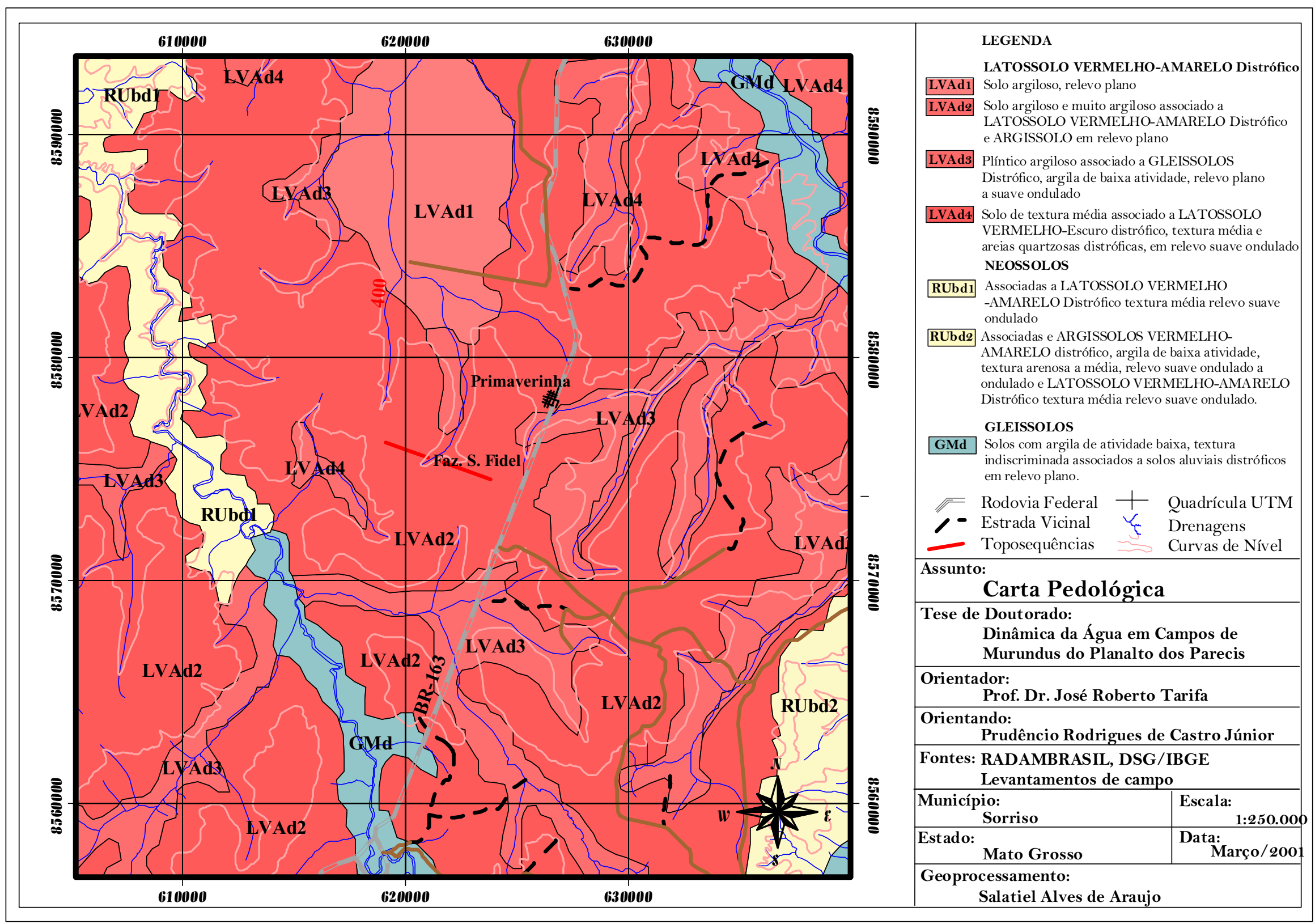

Mapa de solos 


\subsubsection{LATOSSOLO VERMELHO AMARELO Distrófico (LVA)}

São solos minerais, não hidromórficos, caracterizados por apresentarem horizonte B latossólico imediatamente abaixo de qualquer tipo de horizonte A, dentro de $200 \mathrm{~cm}$ da superfície do solo ou dentro de $300 \mathrm{~cm}$, se o horizonte A apresenta mais que $150 \mathrm{~cm}$ de espessura. Apresentam teores de $\mathrm{Fe}_{2} \mathrm{O}_{3}$ inferiores a 9\%, para textura argilosa e relação $\mathrm{Al}_{2} \mathrm{O}_{3} / \mathrm{Fe}_{2} \mathrm{O}_{3}$ superior para textura média.

De modo geral, são solos profundos a muito profundos, bem a excessivamente drenados, bastante permeáveis, muito porosos, tendo pequena relação textural e pouca diferenciação entre os horizontes. Apresentam avançado estágio de intemperismo e processo intensivo de lixiviação, resultando na predominância de minerais de argila do tipo 1:1 e sesquióxidos na composição da fração coloidal, baixa quantidade de minerais pouco resistentes ao intemperismo e baixa reserva de elementos nutritivos para as plantas. Estes solos desenvolvem-se a partir de sedimentos do Quaternário, Terciário-Quaternário e do Grupo Parecis Formações Utiariti e Salto das Nuvens, sendo encontrados com menor freqüência sobre as rochas do Grupo Cuiabá e Formação Diamantino.

Os solos do Grupo Parecis são bem desenvolvidos e bastante intemperizados, possuem estrutura forte ultrapequena granular, com aspecto de pó-de-café. A coloração varia de 7,5YR a 2,5YR, mais freqüentemente 5YR. Quando encontrados no matiz 2,5YR e 10R são denominados no campo como LATOSSOLO VERMELHO. Quimicamente são extremamente pobres, com valores de soma de bases inferiores à unidade e saturação de bases inferiores a 25\%. O alumínio trocável e saturação com alumínio são baixos, exceto alguns perfis, onde a parte superficial, mesmo tendo baixos teores de alumínio trocável, chega a apresentar saturação com alumínio elevada, devido à soma de bases ser muito baixa. A maioria apresenta $\mathrm{Ki}<1$ e valor $\Delta \mathrm{pH}\left(\mathrm{pHKCl}-\mathrm{pHH}_{2} \mathrm{O}\right)$ 
inferior a 0,5 negativo, sendo encontrados $\Delta \mathrm{pH}=0$ e também positivo, evidenciando o alto grau de intemperismo destes solos, provavelmente atingindo o estágio onde há predomínio de óxidos e hidróxidos de ferro e alumínio na fração coloidal. Os solos do Quaternário têm estrutura fraca em blocos subangulares. Quando granular, não apresentam o aspecto pó de café bem característico. A coloração varia entre 10YR e 7,5YR. O Ki é mais elevado, superior à unidade, atingindo valor de 1,97 . O $\Delta \mathrm{pH}$ na maioria é superior a 1 negativo. Possuem baixos valores de soma e saturação de bases. O alumínio trocável e saturação com alumínio são elevados nos solos álicos e baixos nos solos distróficos.

Os solos do Terciário-Quaternário se assemelham mais aos do Parecis, tendo alguns perfis características semelhantes aos do Quaternário ou intermediários. Independentemente do material originário apresentam boas características físicas, sem impedimentos ao desenvolvimento das raízes e manejo, permitindo o emprego de qualquer implemento agrícola, uma vez que, geralmente, são encontrados em relevo plano e suave ondulado. Porém, suas propriedades químicas são limitantes à implantação de projetos agropecuários, necessitando de aplicação de adubos para se obter boa produtividade.

Ocorrem principalmente no Planalto dos Parecis e Planalto dos Guimarães. No Planalto dos Parecis posicionam-se mais a nordeste, nas bacias dos altos rios Xingu, Teles Pires, Arinos e do Sangue, ocorrendo quase sempre associados a LATOSSOLOS VERMELHOS e NEOSSOLOS QUARTZARÊMICOS.

Adubações fosfatadas são importantíssimas, e, ao lado do emprego de calcário visando ao suprimento de cálcio e magnésio, assim como adubações potássicas, contribuem sensivelmente para a melhoria da fertilidade natural, que é uma das limitações básicas destes solos. 
As adubações verdes ao lado da incorporação de restos de cultura nestes solos têm papel importante, principalmente aumentando a capacidade de retenção de umidade e dos fertilizantes aplicados.

\subsubsection{GLEISSOLOS HÁPLICOS Distróficos (GXbd)}

Solos constituídos por material mineral com horizonte glei imediatamente abaixo de horizonte A, ou de horizonte hístico com menos de $40 \mathrm{~cm}$ de espessura; ou horizonte glei começando dentro de $50 \mathrm{~cm}$ da superfície do solo; não apresentam horizonte plíntico ou vértico, acima do horizonte glei ou coincidente com este, nem horizonte B textural com mudança textural abrupta coincidente com horizonte glei, nem qualquer tipo de horizonte $\mathrm{B}$ diagnóstico do horizonte glei.

São solos profundos, mal ou muito mal drenados e desenvolvidos a partir de sedimentos recentes do Holoceno. Apresentam saturação de bases e com alumínio menor que $50 \%$, sendo as demais características as mesmas encontradas na caracterização individual de cada uma destas classes contidas neste trabalho, todavia é importante salientar que os GLEISSOLOS não foram caracterizados individualmente. São fundamentalmente semelhantes aos Glei Pouco Húmicos, da antiga classificação de solos, diferenciando-se apenas por apresentarem horizonte superficial mais espesso, com cores mais escuras e com maiores teores de carbono e matéria orgânica.

\subsubsection{PLINTOSSOLOS ARGILÚVICOS Distróficos (FTd)}

Nesta classe foram enquadrados solos que apresentam forte gleização, em virtude do regime de umidade redutor que se forma nos meios anaeróbicos decorrentes de encharcamentos periódicos ou constantes.

Os PLINTOSSOLOS são solos constituídos por material mineral, com horizonte plíntico ou litoplíntico começando dentro de $40 \mathrm{~cm}$, ou 
dentro de $200 \mathrm{~cm}$ quando imediatamente abaixo do horizonte $\mathrm{A}$ ou $\mathrm{E}$, ou subjacente a horizontes que apresentam coloração pálida ou variegada, ou com mosqueamentos em quantidade abundante ( $>20 \%$ por volume) e satisfazendo uma das seguintes cores: matizes 2,5 Y ou 5Y; ou matizes 10YR ou 7,5YR, com cromas baixos, normalmente igual ou inferior a 4, podendo atingir 6, no caso de matiz 10YR; ou mosqueados em quantidade abundante, se presentes, devem apresentar matizes e/ou cromas de acordo com os itens a ou b e a matriz do solo tem coloração desde avermelhada até amarelada; ou horizontes de coloração pálida (cores acinzentadas, brancas ou amarelo-claras), com matizes e/ou croma de acordo com os itens a ou b, podendo ocorrer ou não mosqueados de coloração desde avermelhada até amarelada.

Sua ocorrência se restringe a áreas deprimidas (cotas baixas) sujeitas a inundações e margens de cursos de água, estando relacionados a sedimentos recentes do período Quaternário, bem como em amplas áreas associadas às nascentes e cursos d'água de 1. ${ }^{\mathrm{a}}$ ordem, do interior deste planalto de largos interflúvios e formas de relevo aplanadas a suavemente onduladas.

São solos profundos, mal drenados, de baixa permeabilidade e características físicas e químicas muito diversificadas, principalmente devido à natureza do material originário, como também à dinâmica do regime hídrico destas áreas.

Quimicamente foram encontrados solos com atividade de argila tanto alta quanto baixa e solos com saturação de bases e com alumínio tanto alta quanto baixa, originando as variações eutróficos, distróficos e álicos.

Em geral o lençol freático se mantém próximo ou à superfície pela maior parte do ano, constituindo-se na principal limitação ao seu aproveitamento agrícola. Este fato faz com que a utilização destes solos 
fique restrita a culturas de ciclo curto, nas épocas não chuvosas, ou então à utilização de culturas adaptadas às condições de umidade, como por exemplo o arroz de várzea.

\subsubsection{NEOSSOLOS QUARTZARÊMICOS Órticos (RQo).}

Nesta classe estão agrupados solos profundos e muito profundos, de pouco desenvolvimento, com seqüência de horizontes do tipo A, C. São solos pouco evoluídos e sem horizonte $\mathrm{B}$ diagnóstico, apresentam horizonte A do tipo moderado e textura nas classes areia e areia franca, com cores claras e avermelhadas em função do material de origem. Sem estrutura formada, apresentam basicamente grãos simples e muito raramente estrutura fraca do tipo granular, assim como muito baixos valores de soma de bases (distróficos) além de na maioria das vezes saturação com alumínio trocável elevada (álicos).

Estes fatores, aliados à baixa capacidade de retenção de umidade, intensa lixiviação, considerável suscetibilidade à erosão e granulometria com teores de areia em torno de $90 \%$, tornam estes solos, praticamente, inviáveis para o uso agrícola, sendo a sua utilização restrita a pastagem em regime extensivo com aproveitamento das espécies vegetais nativas.

Estes solos ocupam extensões significativas, sendo expressiva sua ocorrência no Planalto dos Parecis, Planalto dos Guimarães e Depressão do Alto Paraguai, sobre litologias variadas referidas desde o Quaternário ao Siluriano. Encontram-se associados principalmente a LATOSSOLOS e ARGISSOLOS, ambos de textura média, e ocorrem quase sempre sob cobertura de Savana.

\subsubsection{Vegetação}

Localizada em área de tensão ecológica, a vegetação original da área de pesquisa, segundo classificação utilizada pelo (Radambrasil, 1981), é 
representada pelas fisionomias Savana Arbórea Aberta, com Floresta-deGaleria (Saf), Savana Parque, com Floresta-de-Galeria (Spf). No entorno da área, na porção norte, ocorrem os tipos fisionômicos Savana Arbórea Densa (Sd) e Floresta Submontana, Dossel Emergente (Fse), conforme ilustra a figura $\mathrm{n}^{\circ} 5$.

\subsubsection{Savana Arbórea Aberta (Saf)}

Considera-se a savana arbórea aberta como uma formação vegetal de fisionomia campestre, povoada com arvoretas (scrub) que atingem em média $5 \mathrm{~m}$ de altura e são afetadas pelo fogo anualmente. No centro-oeste brasileiro ela é chamada popularmente de campo cerrado e é caracterizada por um tapete gramíneo-lenhoso contínuo, entremeado de árvores gregárias, geralmente raquíticas, e palmeiras anãs, degradadas pelo fogo anual. Como no caso da savana arbórea densa, a savana arbórea aberta é encontrada mais freqüentemente em áreas areníticas lixiviadas e solos concrecionários, em clima tropical. Apresenta uma composição florística semelhante à da savana arbórea densa, porém com a estrutura mais aberta e mais baixa. A estrutura da savana arbórea aberta é caracterizada por árvores e arvoretas tortuosas, e na maioria das espécies o córtex é bastante suberoso, espesso e sulcado. $\mathrm{O}$ estrato inferior é geralmente constituído de gramíneas formando um tapete contínuo, associadas a outras herbáceas, subarbustos e arbustos baixos. São comuns as plantas de folhas pilosas, lanuginosas, tomentosas e algumas com lepídios, como as bromeliáceas. Entre as herbáceas de folhas pilosas predominam as gramíneas. São numerosas as plantas que produzem flores amarelas, em proporção regular às que produzem flores violáceas, e poucas as que produzem flores azuis, vermelhas e róseas; freqüentemente, há as que produzem flores ou inflorescências vistosas, destacando-se os gêneros Qualea, Kielmeyera, CochIospermum, Tabebuia, Bowdichia e outros.

A espécie arbórea característica, dominante da Savana Arbórea Aberta, em Mato Grosso é a Qualea grandiflora. 


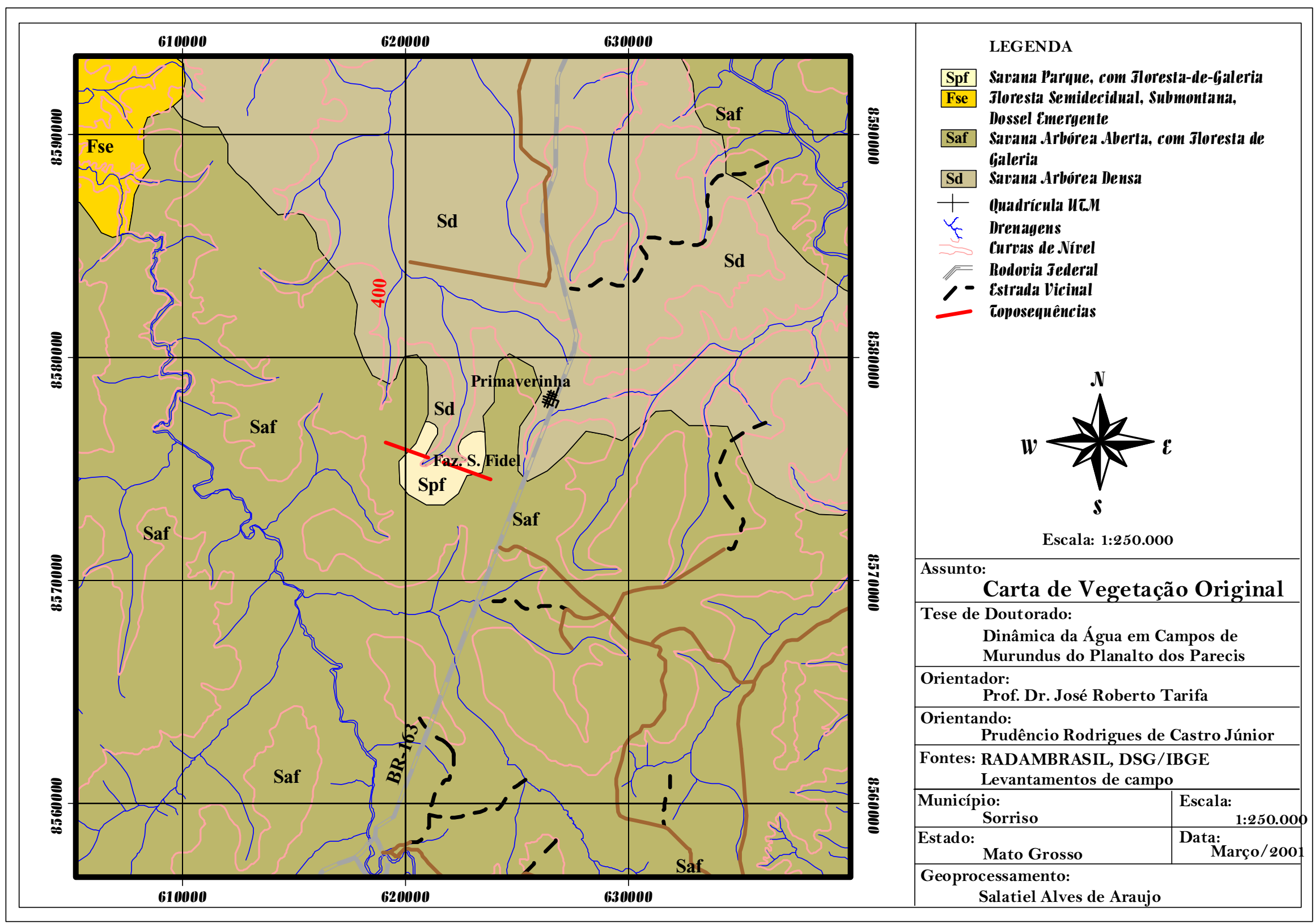

Mapa de vegetação 


\subsubsection{Savana Parque (Spf)}

É uma formação essencialmente campestre, natural ou antrópica, com árvores ou arvoretas esparsas. Quando natural, tem posição geográfica definida, aparecendo nas áreas encharcadas das depressões ou em solos onde a litologia não permite o desenvolvimento de árvores mais adensadas. Quando antrópica é encontrada em toda a Savana alterada pela devastacão humana, ampliada para pastoreio do gado ou para culturas anuais. Em certas áreas, a savana parque apresenta um tapete graminóide com cobertura arbórea esparsa de uma só espécie, como por exemplo a Tabebuia aurea, na Ilha de Marajó e Pantanal Mato-Grossense, conforme ilustra a figura n ${ }^{\circ} 6$.

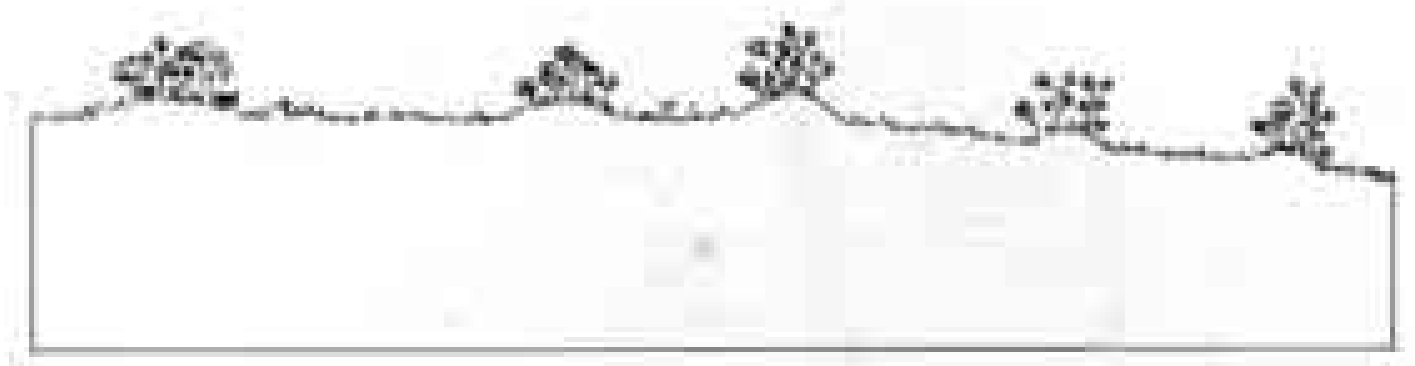

Figura $n^{\circ}$ 6: Perfil esquemático da savana parque

A Savana Parque é conhecida popularmente por "campo sujo". Na sua composição florística predominam as gramíneas mescladas com outras ervas, subarbustos e árvores esparsas, conforme ilustra a figura abaixo. Aparece quase sempre em solos de superfície endurecida, argilosa, com cascalhos de quartzo ou solos ferruginosos. Pode também aparecer em terrenos de areias soltas onde as queimadas tenham sido intensas.

Entre as gramíneas mais freqüentes destacam-se as dos gêneros Tristachya, Aristida, Axonopus, Paspalum Andropogon e outros.

\subsubsection{Savana Arbórea Densa (Sd)}

Considerada por alguns autores como sendo uma forma de transição entre a Savana Arbórea Aberta e a Floresta Estacional, a Savana Arbórea 
Densa caracteriza-se por ser uma formação vegetal florestada, com árvores de médio e pequeno portes que atingem 10-15 m de altura, encontradas princiupalmente nas áreas areníticas lixiviadas e solos concrecionários de clima tropical, eminentemente estacional.

Conhecida popularmente por Cerradão, seu aspecto fisionômico apresenta-se mais desenvolvido e denso que a Savana Arbórea Aberta, porém com árvores e arbustos menos tortuosos. O maior número de árvores constitui uma das características na constituição de maciços, e suas alturas variam de 10-20 metros. Alguns vicariantes da floresta ocorrem nos cerradões.

\subsubsection{Floresta Submontana (Fse)}

Esta formação vegetacional ocorre no Planalto dos Parecis em forma de encraves com a Floresta Aberta. A principal característica na estrutura da vegetação é a presença de árvores emergentes deciduais, tais como: Cariniana spp. (jequitibás), Aspidosperma spp. (angicos), Peltophorum sp. (canafístula) e outras. Nessa formação existe uma submata de arbustos, além de enorme quantidade de plantinhas de regeneração arbórea.

\subsubsection{Clima}

Segundo Sette (2000), a localização central do estado de Mato Grosso no continente sul-americano, bem como a sua extensão longitudinal, posiciona-se numa área de interação entre os sistemas atmosféricos intertropicais com os extratropicais que atingem a região central, com características modificadas/tropicalizadas, como as frentes, anticlone e cavados de altitudes. A autora afirma que o extremo norte e a porção central do Estado, são muito influenciados por padrões de larga escala, associados às mudanças na circulação de Hadley e na circulação de Walker. Os padrões de larga escala atuantes em Mato Grosso são o fenômeno ENSO 
(Oscilação Sul - El Niño/La Niña), a Zona de Convergência do Atlântico Sul (ZCAS) e a Zona de Convergência Intertropical (ZCIT).

As unidades climáticas do estado de Mato Grosso, definidas por Tarifa (1996 e 1998), para o Zoneamento Sócio-Econômico-Ecológico do Estado (Seplan, 2000), elaboradas a partir de metodologia que compatibilizou a crítica do acervo de informações climatológicas com os trabalhos de campo, que incorporou e auxiliou no entendimento das relações entre os atributos e os controles climáticos, encontram-se sintetizadas na figura $\mathrm{n}^{\circ} 7$.

De acordo com Mapa de Unidades Climáticas, a área pesquisada encontra-se na Unidade III: CLIMA TROPICAL CONTINENTAL, alternadamente úmido e seco das Chapadas, Planaltos e Depressões de Mato Grosso. Trata-se na verdade de uma macro-unidade climática, que subdivide-se, devido às muitas variações em função da enorme extensão territorial, tanto em termos de latitude, quanto de longitude, bem como do controle modificador exercido pela forma e orientação do relevo, juntamente com o fator altitude, em 6 unidades intrarregionais:

III.A) Clima Tropical Mesotérmico Úmido dos Topos de Cimeira dos Chapadões.

III.B) Clima Tropical Mesotérmico Quente e Úmido dos Topos de Cimeira dos Chapadões.

III.C) Clima Tropical de Altitude Mesotérmico Quente da Fachada Meridional das Chapadas e Planaltos.

III.D) Clima Tropical Megatérmico Úmido dos Baixos Planaltos e Depressões de Mato Grosso.

III.E) Clima Tropical Megatérmico Sub-Úmido das Depressões e Pantanais de Mato Grosso. 


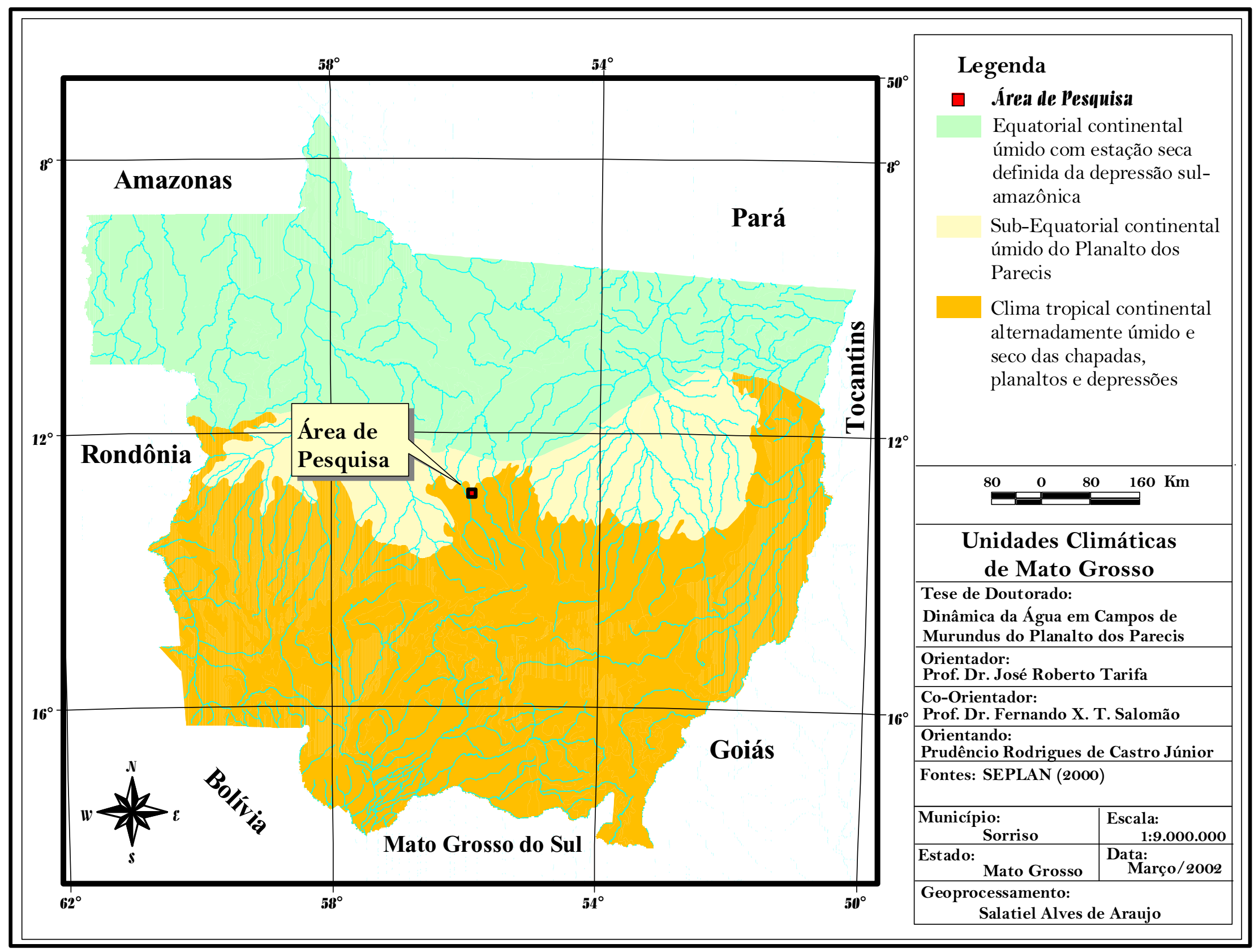

Mapa de unidades climáticas 
Os campos de murundus estudados, situam-se no reverso setentrional do Planalto dos Parecis e no alto curso de um dos principais rios que drenem para a bacia Amazônica, o Telles Pires, numa faixa topográfica em torno de 400 metros, em que o fator altitude constitui-se no controle climático básico, inserindo-se portanto na Unidade III.B, em que os totais pluviométricos variam entre 1.800 a $2.100 \mathrm{~mm}$, apresenta seca estacional moderada entre 250 a $300 \mathrm{~mm}$, abrangendo o período de maio a setembro. Os excessos são de moderados a elevados, apresentando valores entre 800 a $1.100 \mathrm{~mm}$, que predominam durante 6 meses, de novembro a abril.

O gráfico $\mathrm{n}^{\circ} 1$ representa o balanço hídrico de Nova Mutum, que pode ser tomado como representativo para a área estudada, no município de Sorriso.

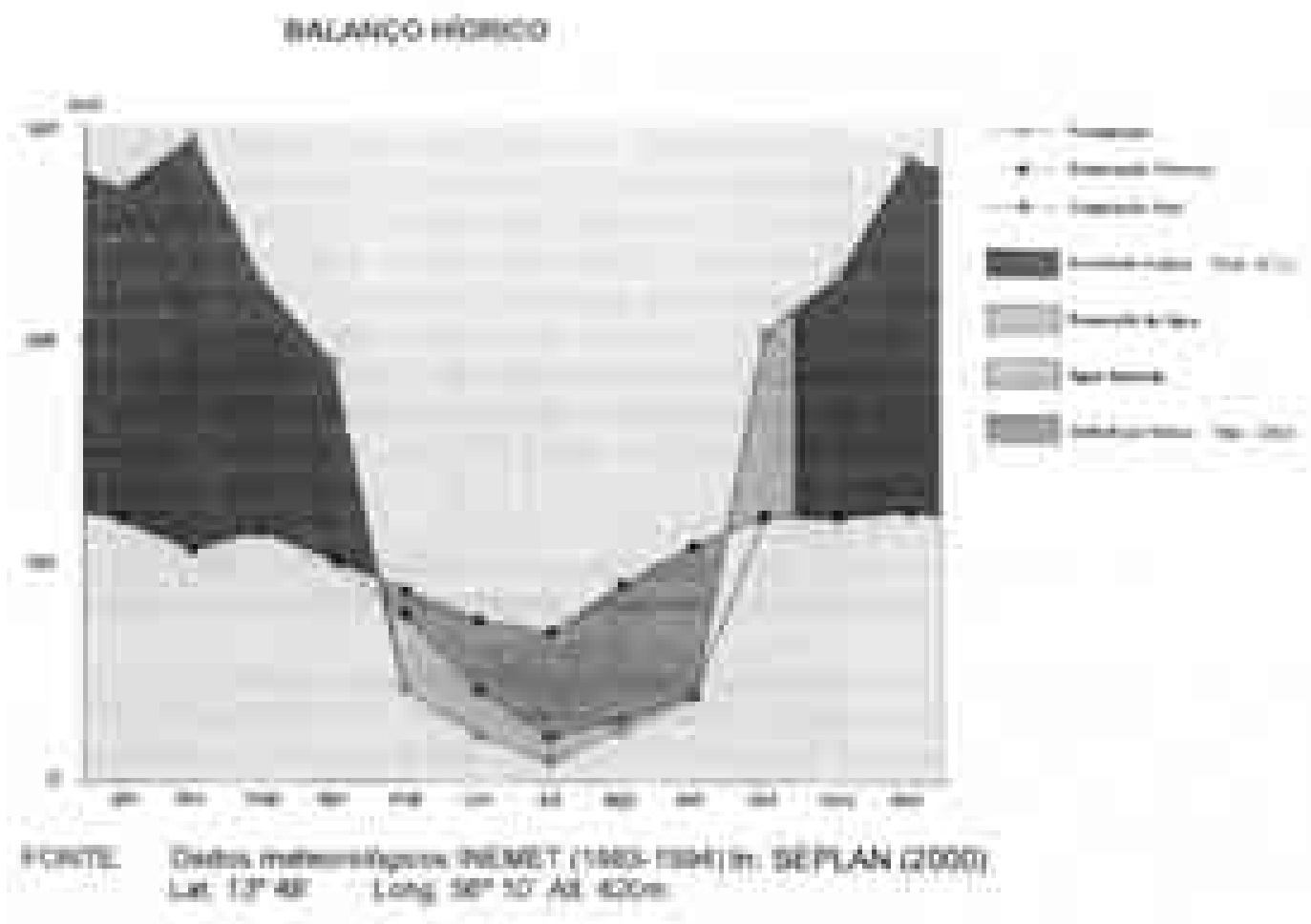

Gráfico nº 1: Balanço hídrico. 


\subsubsection{Uso e ocupação do solo}

No Planalto dos Parecis, o solo, em sua maior parte, vem sendo utilizado para fins agrícolas, mais precisamente, para o cultivo de soja. Até recentemente as atividades agrícolas restringiam-se aos solos secos, atualmente vem se expandindo aos locais onde o solo se satura em água na estação chuvosa, ou seja, nos campos de murundus, cujo nível freático vem sendo rebaixado por meio da escavação de uma rede de valetas. Outra parte é utilizada para a implantação de cidades, vilas, sedes de fazendas e estradas vicinais e federais. A mata de galeria que acompanha os cursos d'água, áreas de preservação permanente, vem sendo parcialmente preservadas, especialmente na parte mais próxima ao curso d'água, conforme ilustra a figura $\mathrm{n}^{\mathrm{o}} 8$.

A ocupação desse Planalto, conhecido como norte matogrossense, ou simplesmente nortão, iniciou na década de 70, durante os anos de governo militar, como uma estratégia de ocupação dos grandes vazios do território brasileiro, denominando-se frente pioneira de colonização.

A distribuição das terras e os assuntos fundiários ficaram a cargo do Instituto Nacional de Colonização e Reforma Agrária - INCRA, com a participação da Sociedade Imobiliária do Noroeste do Paraná - SINOP, em alguns empreendimentos urbanos e rurais.

A ocupação do norte e do noroeste de Mato Grosso, centro-oeste do Brasil, na Amazônia Meridional, foi feita por famílias, na maioria vindas da região sul do Brasil, especialmente do estado do Paraná, motivados pelo sonho do Eldorado, com a esperança de melhorar a condição sócioeconômica, de possuir terras, de aumentar a produtividade e mesmo de enriquecimento. 


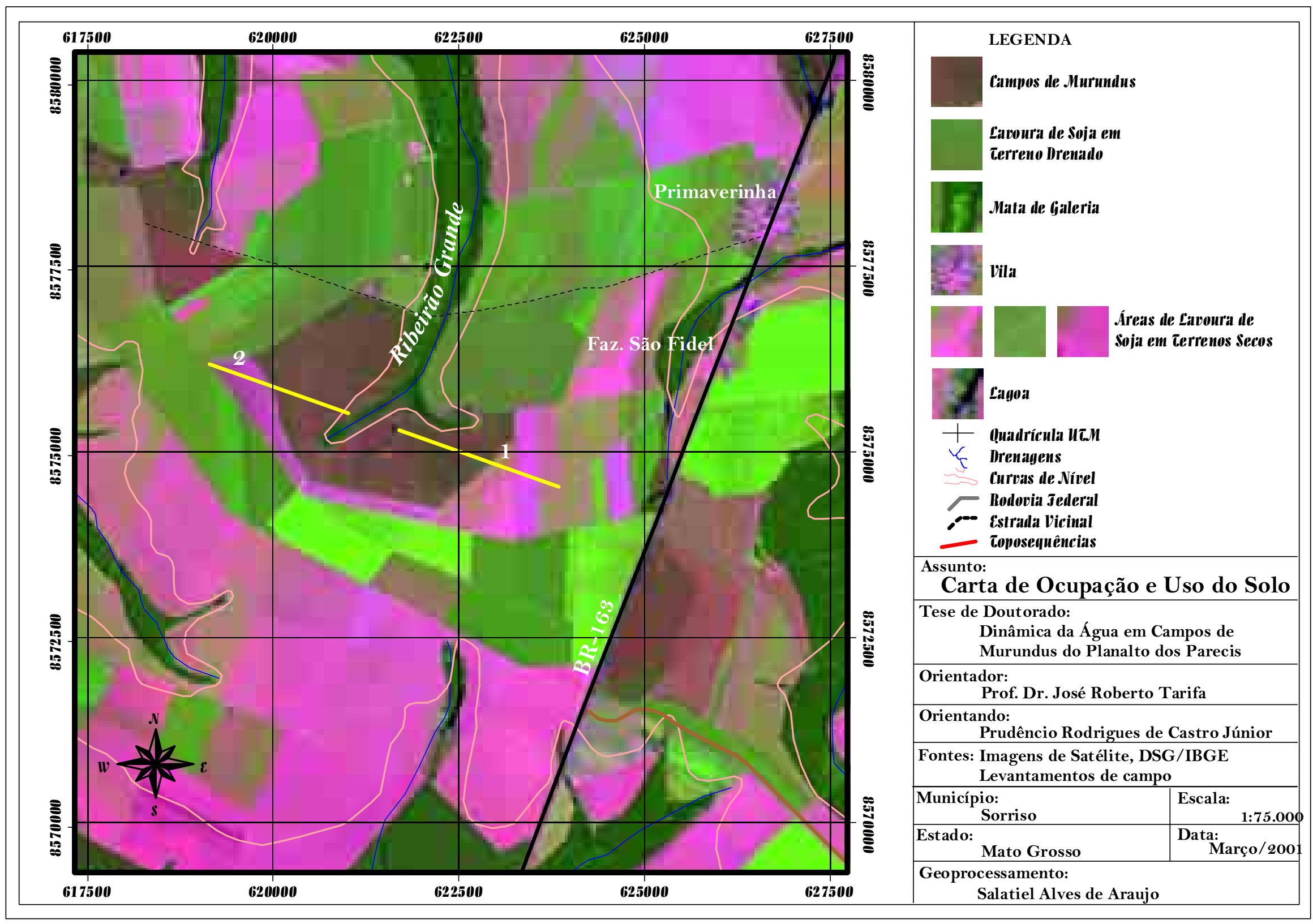

Mapa de Ocupação e uso do solo 
Vencendo inicialmente os obstáculos burocráticos e de documentação colocados pelo INCRA, apresentam-se as dificuldades para a utilização da terra, tais como a distância dos grandes centros, a falta de recursos financeiros, de financiamentos e outros insumos, a precariedade das estradas, dos meios de comunicação, a ausência de telefonia, de bancos, adubos e calcários a preços elevados, bem como a ausência de secadores de grãos, escassez de armazéns e dificuldade de comercialização dos produtos.

A produção durante os primeiros anos de colonização era desanimadora, não permitindo obter lucros, muitas famílias se arruinavam com os prejuízos e retornavam para o sul, ou se estabeleciam em outras cidades de Mato Grosso.

Vencidos os anos difíceis, contando com o favorecimento das condições do relevo, do solo e do clima, que permitem uma boa utilização da terra, as primeiras melhoras começam a ser percebidas no início da década de 80, quando, além do cultivo do arroz, inicia o cultivo da soja, diversificando a produção.

Com relação às características do solo, os principais problemas relacionam-se com a utilização de calcário e de manganês para a correção do solo, visto que as quantidades indicadas pelos laboratórios de análise eram elevadas, causando alguns problemas, bem como a saturação de água no solo em algumas áreas, durante os meses mais chuvosos, especialmente após as grandes pancadas de chuva, que amolecem os solos argilosos, encalhando as colheitadeiras.

Estima-se a presença de aproximadamente $15 \%$ deste tipo de solo dentro dos limites dos municípios de Sorriso e Lucas do Rio Verde, valor percentual que pode ser extrapolado para outros municípios dos planaltos dos Parecis e dos Guimarães, que juntos compõem aproximadamente $50 \%$ 
da área do Estado, onde encontram-se as terras mais favoráveis à agricultura.

Dentro da paisagem, estas áreas com solos que se supersaturam nos meses mais chuvosos e que a água é drenada muito lentamente para o canal fluvial, apresentam-se com topografia plana, ocupando os setores mais à jusante das vertentes. Devido ao relevo plano a suavemente ondulado, com interflúvios muito amplos, muitas vezes é difícil para alguns agricultores perceberem a ligação que estas áreas possuem com as nascentes e os cursos d'água de 1.' ordem, ou seja, os cursos d'água formadores da bacia hidrográfica. Porém, observando-se as fotografias aéreas e as imagens de satélite, esta característica se evidencia nitidamente.

Nestas áreas predomina o LATOSSOLO AMARELO, com alto teor de argila, ocorrendo também o LATOSSOLO VERMELHO-AMARELO, às vezes o LATOSSOLO VERMELHO e até mesmo a Terra Preta, segundo a percepção dos agricultores entrevistados. Embora o solo identificado como terra preta seja o GLEISSOLO da porção mais à jusante das vertentes, onde encontra-se o curso d'água.

As tentativas de utilização destas áreas não foram bem sucedidas, visto que o lento escoamento forma uma lâmina d'água que chega a atingir $10 \mathrm{~cm}$, que se aquece ao sol, favorecendo o desenvolvimento da fauna limnológica, provocando na lavoura doenças fúngicas, como também, não permitindo a operacionalização do solo por meio de tratores e colheitadeiras.

Este problema tem sido resolvido com o rebaixamento do nível freático, por meio da escavação de uma rede de valetas que promovem o escoamento das águas desse lençol suspenso nos horizontes mais superiores do solo e na superfície do terreno, direcionando-as para o canal fluvial. 
Desta forma, as águas retidas pelo solo durante as chuvas intensas, que normalmente demandariam 2-5 dias para escoar para o canal fluvial, por meio da rede de valetas escavadas, ocorre a mudança na velocidade de escoamento, drenando-se em apenas algumas horas, eliminando assim, o problema que os solos supersaturados, com lâmina d'água na superfície do terreno, causam para o bom desenvolvimento da agricultura.

Esta técnica vem sendo amplamente adotada nos planaltos matogrossenses, de maneira que atualmente é difícil encontrar estes campos de murundus intactos 


\section{OS MICRORRELEVOS}

Os microrrelevos possuem ampla distribuição geográfica em nosso País, bem distribuídos nos cerrados do Brasil Central, ocorrendo em campos aluvionares inundáveis das planícies e depressões, bem como em campos brejosos de encosta de planaltos e serras. Apresentam-se com formas circulares com raio ou comprimento de rampa de até $10 \mathrm{~m}$ e altura ou amplitude de até $2 \mathrm{~m}$, nucleados por cupins, recobertos por vegetação lenhosa típica de cerrado que contrasta com os campos-limpos circundantes, conforme ilustra a fotografia n. ${ }^{\circ} 1$.

Dependendo do lugar onde ocorrem, esses microrrelevos recebem várias denominações, sendo murundu a mais comum e amplamente empregada no Brasil Central, com as variantes de murundum e morundu (Diniz de Araújo-Neto 1981, Diniz de Araújo-Neto et al. 1986, Furley 1985

e 1986, Penteado-Orellana, 1980 e Oliveira-Filho 1988), do dialeto quimbundo, segundo Ferreira (1975), significa o mesmo que montículo ou montão. Na serra da Canastra (MG) é conhecido como covoal (IBDF \& FBCN 1981), no Pantanal Matogrossense e na Depressão Cuiabana são comuns as denominações de morrote, cocoruto, capãozinho e ilha (Cunha et al. 1983). Na Planície do Araguaia, entre os estados de Goiás e Mato Grosso é conhecido como varjão e também como monchão (Eiten 1983).

São denominados em língua inglesa como earth platforms (Eiten 1972 e 1975), termite savanna formation (Ratter et al. 1973) termite hillochs (Mathews 1977), cerrado island around termite hills (Prance \& Schaller, 1982) murundu (Diniz de Araújo-Neto et al. 1986, Furley 1985, 
1986, Ratter 1987) hummock (Ratter 1987), mima-mounds (Scheffer 1958, Newcomb 1952, Fairbridge 1968, Péwé 1948, Ritchie 1953 e Cox 1984) e pimple-mounds (Hole 1981). No idioma alemão são conhecidos por termitensavannen (Tröl 1936), em espanhol por cerritos (Sarmiento \& Monasterio 1971) e tatucos (Folster e Huber 1984), ainda, em idioma africano por gilgai (Ozany 1968, Scott 1963, Kalpagé 1976 e Oakes \& Thorp 1951).

São mais conhecidos em áreas periodicamente inundáveis como a Planície do Bananal (Radambrasil 1981), Planícies e Pantanais do Médio e Alto Guaporé (Radambrasil 1982) e Planícies e Pantanais Matogrossenses (Radambrasil 1982), bem como na Depressão Cuiabana (Oliveira-Filho 1988), no Planalto dos Parecis, Planalto dos Guimarães, Planalto Central Goiano (Eiten 1983, Embrapa 1978, Penteado-Orellana 1980, Furley 1985, Ratter 1980 e Diniz de Araújo-Neto 1985 e 1986) e no Planalto Dissecado do Sul do Pará (Eiten 1983)

Os primeiros estudos acerca de microrrelevos foram publicados por Dalquest \& Scheffer (1942) acerca dos fatores bióticos ou abióticos que participam da formação de pequenos montes denominados Mima-mounds que ocorrem no oeste dos Estados Unidos, e por Scheffer (1958) que discute a atividade subterrânea de um roedor Geomyidae (Thomomys spp.), embora Newcomb (1952) considera que esse roedor desempenha papel secundário. Por outro lado, Fairbridge (1968), Péwé (1948) e Ritchie (1953) explicam a origem dos Mima-mounds por meio de processos erosivos.

Pesquisando na região do Pantanal Matogrossense, Cole (1960) afirma que a Curatella americana, popularmente conhecida como lixeira, cresce junto de termiteiros, ao redor dos quais acumulam-se sedimentos, posicionando assim os microrrelevos acima da cota de inundação. 
Estudando os campos brejosos de encosta na serra do Roncador (MT), Eiten $(1972,1975)$ considera o cupim como fator determinante na formação de murundus, sugerindo que os seus edifícios foram construídos com o mesmo material gleizado dos campos brejosos, diferente do latossolo da parte superior da encosta, com a finalidade de colocar seus ninhos acima do alcance da saturação de água do solo. O mesmo autor afirma não poder acreditar que os murundus, cuja proporção de solo é bem maior que a dos endurecidos cupinzeiros, se originam a partir da degradação dos cupinzeiros devido ao fato de que todos os edifícios observados já estavam abandonados ou mesmo em degradação.

Em analogia com as savanas de cupins da África, denominadas por Tröll (1936) de termitensavannen, descritas por Pullan (1979) como grandes montes de terra recobertos por vegetação savânica, originada pela atividade das térmitas, considerada assim uma paisagem fóssil, Ratter et al. (1973) refere-se aos campos de murundus da planície do Araguaia e da serra do Roncador como termite savanna formation.

Os murundus dos campos brejosos de encosta, típicos da região de Sagarana (MG) foram definidos como concentração de termiteiros (Fundação João Pinheiro, 1975), bem como do Pantanal Matogrossense, em que Prance \& Schaller (1982) atribui às térmitas o surgimento e o crescimento de pequenas ilhas recobertas por vegetação de cerrado, esparsas em vegetação de gramíneas, ou de campo limpo.

Trabalhando nos mesmos campos brejosos de encosta da serra do Roncador (MT), citados por Eiten $(1972,1975)$ e por Ratter et al. (1973), Mathews (1977) formula a teoria mais elaborada e detalhada acerca da origem e fornação dos murundus pela atividade das térmitas. Essa teoria pressupõem 3 fases distintas: $1^{a}{ }^{a}$ ) uma espécie de cupim mais tolerante aos solos úmidos, a Armitermes cerradoensis, instala-se no campo durante o 
período seco, construindo um pequeno ninho na base do tufo de uma gramínea; 2. ${ }^{a}$ ) a colônia de Armitermes cerradoensis morre, o cupinzeiro se desestrutura, e o monte de terra continua a ser aumentado nas estações úmidas por Anoplotermes sp e por minhocas, podendo ser colonizado por plantas menos tolerantes aos encharcamentos; $3 .^{a}$ ) nos montes de terra maiores e durante as estações secas mais prolongadas, uma terceira espécie de cupim, a Cornitermes snyderi se instala, construindo cupinzeiros bem mais volumosos e pouco tolerantes aos encharcamentos, exigindo uma plataforma maior e mais seca. A partir daí os cupinzeiros de C. snyderi são permanentemente atacados e destruídos total ou parcialmente por tamanduás e tatus e, constantemente reparados ou reconstruídos pela mesma colônia ou por novas, durante longos períodos, formando montes de terra cada vez maiores ao redor dos cupinzeiros, que passam a ser ocupados por plantas lenhosas de cerrado, que fornecem abrigo e alimentação para os cupins e outros animais, especialmente nos períodos de alagamento. A uniforme distribuição dos murundus nos campos brejosos, reflete, segundo Mathews (1977), a divisão dos territórios de forrageamento, que são hostis entre si.

A partir de 1980, os fatores abióticos ou do meio físico, também conhecidos como processos de dinâmica superficial, especialmente a erosão, vem sendo considerados como fundamentais na formação dos murundus.

Estudando os murundus de campos brejosos de encosta, também conhecidos como veredas, na Fazenda Água Limpa, próximo ao Distrito Federal, no Planalto Central Goiano, Penteado-Orellana (1980) considerou a evolução paleoclimática das paisagens do Brasil Central durante o período Quaternário, mais especialmente da época Holoceno, para explicar a formação dos microrrelevos. Segundo a autora, os murundus surgiram em antigas rampas coluviais onde o paleossolo teria sido seccionado na parte 
inferior das encostas por reentalhamento erosivo no último período úmido durante os últimos 2.500 anos, sendo os murundus relíqueas de um paleorrelevo que remanescem nos sítos onde se instalaram os cupinzeiros.

Posteriormente, Furley $(1985,1986)$ e Diniz de Araújo-Neto et al. (1986), estudando com maior detalhe os mesmos campos de murundus da Fazenda Água Limpa no Planalto Central Goiano, analisando a configuração e distribuição dos microrrelevos e os solos, o regime do lençol freático, a vegetação e a atividade de cupins nos murundus e nas superfícies intermurundus, consideram 4 fatores que contribuem com a formação dos murundus: $10^{\circ}$ ) a ação erosiva da água superficial; $2 .^{\circ}$ ) cimentação do solo por atividade de insetos; $3 .^{\circ}$ ) afloramentos lateríticos ou de outro material rochoso e $4 .^{\circ}$ ) cobertura vegetal que tende a reter maior volume de solo.

Levando em conta esses fatores, o escoamento superficial difuso das águas pelas encostas promove a escavação de canais, formando pequenos sulcos, acentuando pequenas diferenças na superfície original, que era recoberta por cerrado durante o último período seco, ou seja, durante a época Holocênica, iniciada por volta de 10.000 anos atrás. O clima cada vez mais úmido, vem favorecendo o avanço dos campos brejosos encosta acima, provocando a retração dos cerrados. A elevação do nível freático até o extravasamento da água em níveis cada vez mais alto, em fluxo difuso na superfíce das encostas, formam pequenos sulcos entrelaçados, destacando novos murundus nas margens da vegetação de campo limpo que faz contato com o cerrado. Dessa forma, os murundus são relíqueas do relevo, do solo e do cerrado primitivo.

Os campos brejosos de encosta assemelham-se às veredas, descritas por Lima (1996) como sendo anfiteatros com vertentes suaves, recobertas por vegetação graminosa, com lençol freático aflorante e drenagem difusa, circundada por vegetação de cerrado, podendo ou não ter buritis alinhados 
ao eixo de drenagem. Estudando as veredas do Ribeirão Panga nos chapadões do triângulo mineiro, o autor verifica que apresentam um perfil topomorfológico tranversal com conformação de vale aberto, de fundo em berço, com vertentes sub-retilíneas ou ligeiramente convexas, com declividades suaves ( $<3 \%)$, abaixo das quais os solos são hidromórficos.

Muitas veredas possuem murundus, ativos ou fósseis, edificados sobres as gramíneas do campo-limpo, nesse caso, não há como diferenciar vereda de campo brejoso de encosta ou campos de murundus.

Durante a evolução do relevo da Bacia Sedimentar do Parecis, da mesma forma como na Bacia Sedimentar do Paraná, deve ter ocorrido uma superfície de erosão pós-cretácea (Almeida 1959 e Ab’Sáber 1973) ou Sulamericana (Terciária) de King (1956), configurando um nível testemunhado pelo topo dos chapadões, em que esse processo se inicia, segundo Lima (1996) a partir da instalação de uma drenagem em locais preferenciais de acumulação de umidade, em uma condição peculiar de topografia, em zonas de falhamentos ou fraturas de rochas, ou então, em zonas de falhamentos. Com a intensificação da pedogênese, relacionada às transformações por hidromorfismo, a topografia se inclina por abatimento e promove a incisão do vale, que não é fluvial e sim geoquímico.

As veredas, de acordo com Lima (1996), da mesma forma como os campos brejosos de encosta, se originam nesse momento, quando os vales assumem uma conformação de fundo chato e vertentes sub-retilíneas, ou suavemente convexas e o relevo regional passa a ser suave-ondulado. Os processos erosivos só passam a ter importância a partir da inclinação das vertentes, enquanto que os pedogenéticos continuam atuando.

Estudando um campo de monchões na Depressão Cuiabana, Oliveira-Filho (1988) percebe evidências de que os cupins desempenham um papel fundamental e determinante no longo processo de formação, e que 
o solo dos murundus forma-se a partir da degradação e erosão de sucessivas gerações de cupinzeiros, possuindo textura mais fina devido a atividade dos próprios cupins.

O campo de murundus estudado por Oliveira-Filho (1988) localizase em uma depressão circular sazonalmente alagável, sem relação com a rede de drenagem organizada, popularmente conhecido como embaciado, pertencente a uma unidade de geomorfológica morfoescultural do tipo depressão (Ross 1992), assemelhando-se muito aos campos de murundus de unidades morfoesculturais do tipo planície, como é o caso da planície de inundação dos rios Araguaia, Tocantins e Paraguai.

Em várias regiões do mundo os microrrelevos vem sendo estudados, como é o caso das formações do tipo mima-mounds da África, estudados por Cox (1984), dos gilgai, da região de Nairobi, no Quênia, interpretados por Ojany (1968) como derrames de lama, por Scott (1963) como atividade de cupins e por Kalpagé (1976) e Oakes \& Thorp (1951) como contrações e expansão da argila montmorilonita devido a variações do teor de umidade.

Nos Estados Unidos, microrrelevos conhecidos como pimple-mounds são tidos como de origem eólica e alguns mima-mounds como de origem periglacial (Hole, 1981).

Nas savanas da Venezuela, os microrrelevos denominados cerritos são relacionados por Sarmiento \& Monasterio (1971) a processos erosivos, enquanto que os tatucos que ocorrem na transição savana-floresta na amazônia venezuelana, segundo Fölster e Huber (1984), se originaram por dissolução erosiva circular.

Nos planaltos do Quênia, na África oriental, microrrelevos cuja origem era atribuída a atividade de cupins, passa a estar vinculada a um 
rato-toupeira (Rhizomydae) por Cox \& Gakahu (1983) e Gakahu \& Cox (1984).

Na Grã Bretanha, (King 1977a, 1977b, 1977c) Estados Unidos (Beattie \& Culver 1977, Culver \& Beatie 1983) e União Soviética (Malozemova 1970, Malozemova \& Kouma 1973) demonstraram que as formigas também influem na composição e estrutura da vegetação que circunda seus ninhos, ao elevarem seus montes de terra e alterarem a química dos solos.

$\mathrm{Na}$ Austrália, certos tipos de cupins podem ter contribuído para a formação de um horizonte A de solo argiloso de $20 \mathrm{~cm}$ de profundidade, em North Queensland (Holt et al. 1980).

No Brasil, no Planalto Central Goiano, Egler (1984) observou que os cupins concentram a atividade de construção dos ninhos no início e no final da estação chuvosa, transportando 8,5 ton./ha/ano de solo, aumentando seus termiteiros em cerca de $40-70 \%$ do volume.

A erosão pluvial, bem como a atividade dos termitófagos, alteram as propriedades físicas e químicas ao redor do ninho dos cupins (OliveiraFilho 1988). A granulometria dos solos dos cupinzeiros e suas adjacências é geralmente mais fina que a dos solos do local, devido ao selecionamento dos grãos pelo transporte das operárias (Arshad 1981, Banerjee \& Mohan 1976, Boyer 1975, Holt et al. 1980, Laker et al. 1982a, 1982b, Lee \& Wood 1971b, Midena \& Van Wuure 1977, Pathk \& Lehri 1959). Embora em certos casos não se observa diferenças entre a textura dos cupinzeiros e dos solos onde ocorrem. (Egler 1984 e Hesse 1955).

$\mathrm{O}$ acúmulo de material vegetal nos ninhos dos cupins, bem como o conteúdo fecal e a saliva utilizados na cimentação das paredes dos seus edifícios, confere fertilidade aos cupinzeiros, tornando-os mais ricos em 
nutrientes e sais minerais, conforme foi observado no Quênia por Arshad (1981), Fries \& Fries (1948), Hesse (1955) e Pommery (1983), na África do Sul por Laker et al. (1982 a, 1982b), em Serra Leoa por Miedema \& Van Vuure (1977), em Zâmbia por Trapnell et al. (1976), na Índia por Banerjee \& Mohan (1976) e Pathak \& Lehri (1959), na Austrália por Lee \& Wood (1971a, 1971b), na América do Sul e Amazônia por Salick et al. (1983) e no Brasil por Egler \& Harudasan (1983).

A fixação de nitrogênio no solo devido a atividade das térmitas foi observada por Parker et al. (1982), Roy-Nöel (1979) e Schaeffer \& Witford (1981) nos desertos do Novo México nos Estados Unidos.

Os cupinzeiros e seus arredores são considerados como sítios de boas condições hídricas, bem drenados e com maior disponibilidade de água (Arshad 1981, Banerjee \& Mohan 1976, Bodot 1967, Fries \& Fries 1948, Lee \& Wood 1971a, Pathk \& Lehri 1959).

Conforme observou Hesse (1955) ninhos com colônias ativas são bem endurecidos e compactos, dificultando a penetração de raízes, sendo que o monte das colônias, segundo Bodot (1967), as formigas ocupam os ninhos, que são parcialmente destruídos por termitófagos, expondo-os à erosão e destruição parcial, facilitando a sua colonização pelas plantas.

Uma teoria para a formação desses microrrelevos é formulada por Pullan (1979, em Oliveira-Filho 1988) envolvendo a atividade dos cupins, e a interferência da vegetação, da erosão, dos grandes mamíferos e do homem. Segundo essa teoria, a construção do edifício é feita com o transporte de terra por sucessivas gerações de colônias de cupins, enquanto a formação de um pedimento ao redor do ninho deve-se à erosão do cupinzeiro pela água da chuva e também à destruição por tatus e tamanduás, além de outros animais mamíferos termitófagos, como o porco-formigueiro e o pangolin-do-cabo. O monte é colonizado por uma vegetação mais densa 
conferindo-lhe proteção contra a erosão. Os grandes mamíferos e o homem atuam no sentido de destruí-lo. Os elefantes escavam esses microrrelevos com as presas para comer sua terra rica em minerais, enquanto carnívoros como o guepardo e o leão utilizam-os como ponto de observação e os antílopes e búfalos se reúnem para defecar, pisoteando, e destruindo a vegetação, diminuindo a amplitude do monte e aumentando o cumprimento de rampa, bem como, semeando espécies da vegetação da savana pelas sementes contidas nas suas fezes. O homem destrói esses microrrelevos para praticar a agricultura, a pecuária e outras atividades de uso do solo.

Comparando os montes de cupin da África com os murundus do Brasil Central, Oliveira-Filho (1988) verifica que em ambos os casos os microrrelevos tem forma convexa, ocorrem em ambientes savânicos, apresentam vegetação e solos diferentes das superfícies circundantes, ostentando com freqüência, termiteiros no seu cume. Entretanto, no caso sul-americano, os microrrelevos e os cupinzeiros são, em geral, menores e mais achatados, ocorrendo nos campos úmidos estacionais, enquanto na África, ocorrem tanto nas savanas úmidas como nas secas. Os murundus de cerrado em solos bem drenados são raros no Brasil. Além disso, na América do Sul, não existem, como na África, os cupins criadores de fungos, que estão associados aos microrrelevos das savana africanas.

Contudo, na África como na América do Sul, as formigas são grandes predadoras de cupins e invasoras dos ninhos (Wheeler 1936), enquanto os mamíferos termitófagos africanos como o porco-formigueiro e o pangolim encontram seus equivalentes ecológicos neotropicais no tamamduá e no tatu, principais predadores e destruidores de cupinzeiros, conforme ilustra a fotografia $\mathrm{n}^{\circ} 2$. Em ambos os continentes, os cupins desempenham um papel fundamental nesses ecossistemas, influindo nos solos, na vegetação e no variado número de espécies que deles dependem diretamente, entre predadores e inquilinos (Fontes 1979), sendo o cupim de 
montículo considerado por Redford (1984) como uma espécie-chave dentro do sistema ecológico.

Examinando atentamente os fatores que participam da origem e da formação dos murundus, sintetizando esse complexo processo, OliveiraFilho (1988) concorda com Araújo-Neto et al. (1986) e Furley (1986) no que diz respeito ao papel fundamental que a erosão diferencial desempenha na formação dos campos de murundus de encostas, unidades de relevo pertencentes a planaltos e serras, formados por processos degradacionais, especialmente por erosão hídrica, já que os processos de escoamento superficial e ressumagem da água ocorrem somente nas superfícies intermurundus.

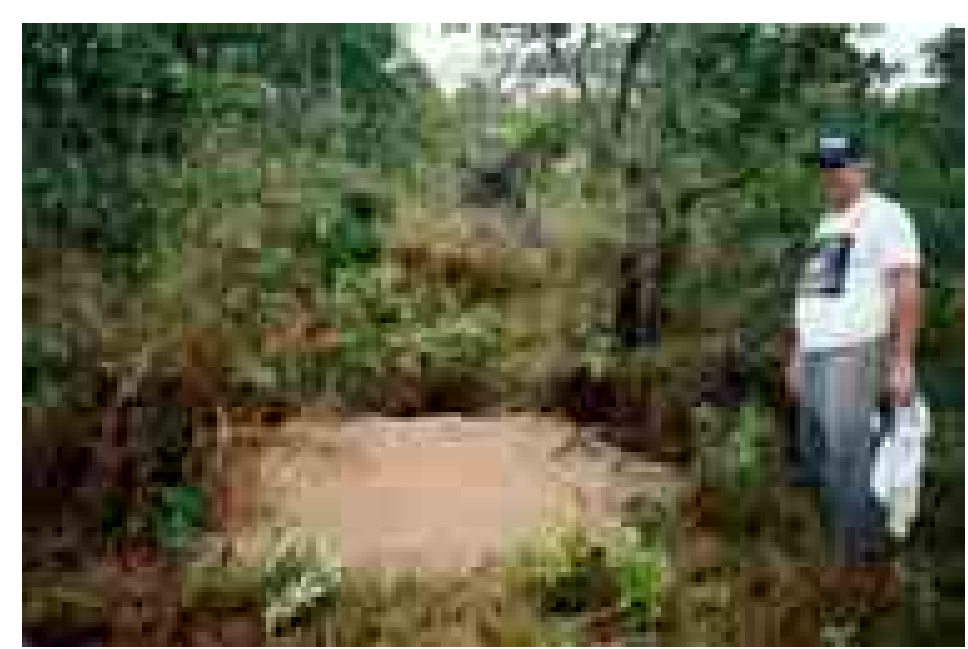

Fotografia n. $^{\circ}$. Microrrelevo sendo destruído por escavação de tatus.(CastroJunior, 2001).

Entretanto, para o caso dos campos de murundus de aluvião, ou campos aluvionares inundáveis, como os do pantanal matogrossense e planície do Araguaia, unidades geomorfológicas em que os relevos formam-se por processos agradacionais, ou seja, por deposição de sedimentos, bem como os embaciados no interior das depressões, não se aplica a hipótese da erosão diferencial. Para essas planícies inundáveis que vem passando por sedimentação, os murundus elevam-se acima do nível das inundações e a partir do leito da planície, neste caso, a atividade biológica dos cupins desempenha papel fundamental, senão determinante, 
na formação dos microrrelevos. O estudo dos murundus de solos secos, raros e pouco conhecidos, podem contribuir para o esclarecimento do papel dos cupins, bem como da erosão diferencial na formação de microrrelevos.

Examinando campos de murundus em fundos de depressões fechadas e na base de vertentes de depressões abertas, no Planalto Central Brasileiro, no estado de Minas Gerais, Correa (1989) levanta argumentos a favor da origem biológica desses microrrelevos, que não se aparentam com os termiteiros gigantes das savanas africanas, embora sejam resultantes da atividade de uma certa colônia de térmitas. A edificação dos murundus é, a exemplo daqueles observados por Souer (1983) em Shaba no Zaire, resultantes de processos cumulativos de transporte de matéria, ligado a atividade da fauna do solo, essencialmente das térmitas. Esta atividade é condicionada pelo excesso temporário de água no solo e se prolonga pelos ciclos repetidos de construção e destruição de termiteiros, em que várias espécies de térmitas participam do processo.

Nas áreas pesquisadas por Correa (1989), as relações solo-campos de murundus mostram uma cobertura pedológica uniformemente muito argilosa, muito alterada e muito pobre em elementos nutritivos. Os solos são uniformemente microagregados. Na passagem dos interflúvios para as zonas deprimidas, os solos mostram uma passagem progressiva de cores vermelhas amareladas para cores brunas e depois cinza, topossequência de cores muito freqüentes no Planalto Central Brasileiro, que segundo Macedo \& Bryant (1987 e 1989) está ligada a transformação de óxido de ferro em goetita e hematita, por meio de um gradiente de umidade edáfica.

Os campos de murundus ocupam a parte das topossequencias em que os solos estão sob a presença sazonal do excesso de água. No interior de um campo de murundus, com evidências de atividades termíticas responsáveis pela edificação atual dos montículos, são mais abundantes as cores cinza 
e/ou as segregações de óxidos de ferro e a aparente hidromorfia (Correa, 1989).

O exame de fotografias aéreas revelou a esse autor a organização dos microrrelevos. Em vertentes com depressões fechadas, os montículos dispõem-se em auréolas, enquanto que em vertentes com depressões abertas, distribuem-se grosseiramente perpendiculares à declividade da encosta. Esta organização revela que a formação dos murundus segue a evolução do nível médio do lençol freático, que por sua vez, está sob a dependência de processos que formam hoje essas depressões.

A síntese da vegetação dos murundus em savanas tropicais, é elaborada por Ponce \& Cunha (1993), com especial referência ao Pantanal de Mato Grosso. Os autores ressaltam que o bioma do tipo savana ou cerrado caracteriza-se pela adaptação a uma longa estação seca, que muitas vezes estende-se por 7 meses, ocorrendo variações fitofisionômicas e florísticas entre cerrado, campo e floresta de galeria, determinadas pelo nível do lençol freático.

A vegetação de cerrado requer solos bem drenados com longo tempo de acumulação de água durante a estação chuvosa, ao contrário da floresta galeria, cujas árvores estão adaptadas a drenagem pobre e solos supersaturados. Posicionado entre o cerrado e a floresta galeria, a vegetação de campo, dominante nas planícies inundáveis, é bem adaptada às condições de extrema alternância entre saturação e dissecação.

A natureza dos microrrelevos é explicada em termos de competição entre duas comunidades de plantas, as do cerrado, endêmicas nas savanas do Brasil Central, e as de campo, bem adaptadas às condições de extrema alternância entre saturação e dissecação, onde são construídos os murundus por atividade de térmitas, criando o ambiente adequado, com solo bem 
drenado e acima do nível de saturação, para o estabelecimento e desenvolvimento da vegetação de cerrado.

No Planalto dos Parecis é comum a presença de microrrelevos, examinando fotografias aéreas e imagens de satélite, percebe-se que essas paisagens ocorrem contornando as nascentes e cursos d'água de primeira ordem, que são os cursos d'água formadores da bacia hidrográfica, no caso do Planalto dos Parecis, são os formadores da bacia amazônica em sua porção meridional.

Examinando-se as amplas colinas desse Planalto percebe-se que os murundus estão presentes em concentração pequena a média no terço inferior das vertentes, ou seja, na parte mais próxima ao curso d'água, à medida que vai subindo topograficamente os murundus são mais freqüentes, sendo que na parte mais alta da vertente, em que os solos não estão mais sujeitos às inundações sazonais os murundus são bem freqüentes, porém com fisionomia distinta, pois os montículos apresentam-se bem espalhados pelo revolvimento dos tatus e tamanduás, de maneira que a sua altura foi rebaixada e o comprimento de rampa aumentado, de tal forma que um parece tocar o outro, necessitando uma observação bem atenta para individualizar cada montículo.

Nesses casos, a vegetação de cerrado espalha-se por toda a superfície do terreno, sem individualizar ilhas como ocorre nos terços médio e inferior da vertentes, o estrato graminoso mistura-se ao estrato arbóreo do cerrado. Essas áreas atualmente não estão sujeitas às inundações sazonais, mas a presença desses montículos ou cupinzeiros já abandonados pelas térmitas e aplanados pelos predadores, indica que anteriormente a inundação sazonal alcançava também aquela parte, devendo portanto ter ocorrido o rebaixamento do nível freático, o que permite supor que está diminuindo a água disponível no solo. 
Examinando a formação de novos montículos na área objeto da pesquisa, percebe-se que alguns edificam-se na própria superfície inundada pela atividade biológica das térmitas, enquanto outros iniciam com o crescimento de vegetação de cerrado em pequenas ilhas que foram isoladas pelo fluxo entrelaçado da água de chuva na superfície de solo supersaturado, aparentemente sem ligação com a atividade das térmitas. Esta observação admite a possibilidade de surgimento dos murundus em um mesmo campo brejoso de encosta, por meio das duas teorias vigentes, ou seja, a física, por meio de erosão diferencial, e a biológica, devido a atividade dos cupins, conforme ilustra a fotografia n. ${ }^{0} 3$.

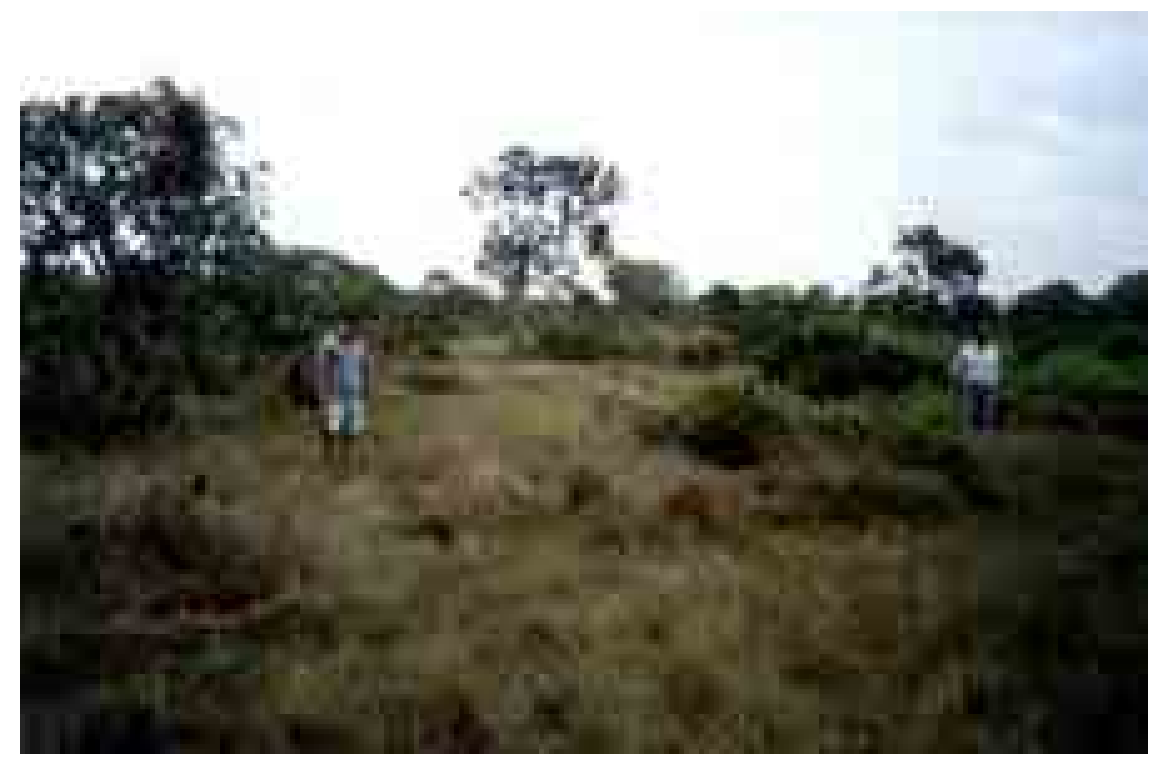

Fotografia n. ${ }^{\circ 3}$ : Formação de murundus em termiteiro vivo (1) e em GLEISSOLO (2) (Castro-Junior-2001)

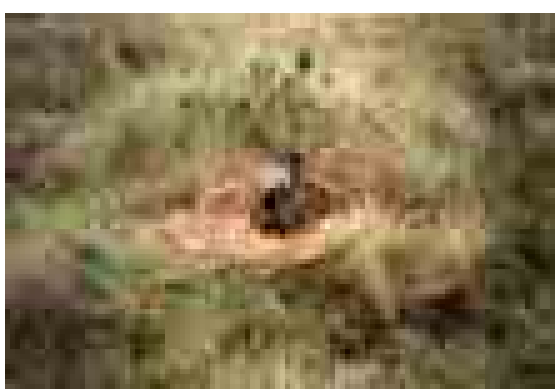

(1)

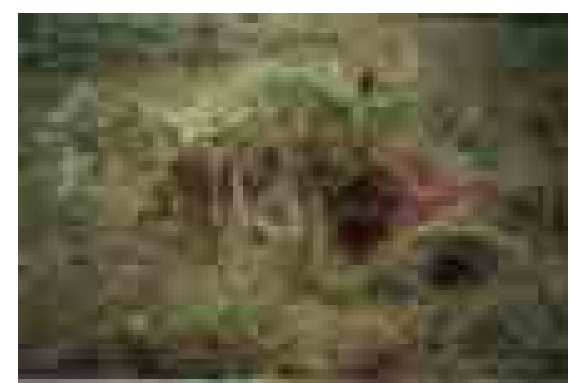

(2)

Detalhes da fotografia $n^{\circ} 3$ 


\section{A COBERTURA PEDOLÓgiCa}

As coberturas pedológicas com diferenciações lateral e vertical ocorrem sistematicamente na paisagem, constituindo os elementos fundamentais de distinção dos sistemas pedológicos. Constituem-se de horizontes com determinada distribuição espacial na vertente, que apresentam comportamentos hídricos específicos, formando seqüências com evidentes significados genéticos (Boulet, 1987), permitindo caracterizar interflúvios elementares de mesma família, de acordo com o estado de evolução, e cartografa-los de maneira sistemática (Salomão, 1994).

Nesta pesquisa caracterização das coberturas pedológicas foi feita em duas vertentes representativas em campos de murundus, nas cabeceiras do ribeirão Grande, afluente do rio Telles Pires, na Fazenda São Fidel, Km 700 da rodovia BR 163, município de Sorriso, no Planalto dos Parecis, estudadas ao nível de topossequência. Os procedimentos metodológicos foram apresentados no item 1.3.

\subsection{Topossequência $A$}

A toposseqüência $\mathrm{A}$, localizada em uma vertente na margem direita da cabeceira do ribeirão Grande, considerada como representativa do Planalto dos Parecis, instalada em uma colina ampla, com forma retilínea e muito longa, comprimento de rampa superior a 2500 metros, topo muito amplo e 
ligeiramente aplanado, com largura em torno de 1000 metros, amplitude de 20 metros. As declividades dessa vertente variam entre 0 - 5\% no terço superior, $0,5-1,5 \%$ no terço médio e de $1,5-0 \%$ no terço inferior, com rupturas de declives bem discretas, percebidas na elaboração do perfil topográfico sobre papel milimetrado.

A utilização da terra nessa colina vem sendo feita por lavoura de arroz e de soja no terço superior desde 1998, com drenos escavados para o escoamento da água pluvial acumulada na superfície do terreno, parte do terço médio foi desmatado em 1999 para lavoura de soja e no terço inferior encontram-se os campos de murundus preservados.

A cobertura pedológica da parte inferior da topossequência é o PLINTOSSOLO ARGILÚVICO Distrófico, enquanto que na parte média e superior da vertente ocorre o LATOSSOLO BRUNO Distrófico câmbico e o Distroférrico plíntico A figura 9 representa a topossequência A, dando a indicação da disposição bidimensional dos seus principais horizontes.

1. Microrrelevo de $0,50 \mathrm{~m}$ a $1,00 \mathrm{~m}$ de altura, cor cinza muito escuro (10YR 3/1), textura argilo-arenosa, estrutura grumosa bem desenvolvida, consistência seca dura, úmida ligeiramente friável ou macia, molhado é plástico e pegajoso. Raízes comuns, bioporos milimétricos a centimétricos de formigas e cupins. Presença se pedotúbulos milimétricos a centimétricos, alguns com revestimentos amarelos. Porosidade de amontoamento dos agregados, porosidade fissural, porosidade biológica e porosidade tubular fina.

2. Horizonte de solo de $10-15 \mathrm{~cm}$ de espessura que recobre toda a superfície da vertente. No terço inferior é constituído essencialmente por serrapilheira e liteira de cor cinza muito escuro (10YR 3/1) e matéria orgânica desbotada com manchas de cor cinza muito escuro (10YR 3/1) e bruno pálido (10YR 6/3), outras vezes por película orgânica ressecada com muitas raízes finas embaixo, presença de agregados arredondados 
que se aderem facilmente na mão, apresenta, de maneira geral, cor cinza escuro (10YR 4/1) com manchas mais claras de cor cinza (10YR 6/1) e algumas de cor amarela brunada (10YR 6/6), textura argilo-arenosa, estrutura grumosa bem desenvolvida, torrões de 2 a $3 \mathrm{~cm}$ que se desfazem em agregados de até $1 \mathrm{~mm}$. Consistência seca dura, úmida é ligeiramente friável ou macia e molhado é plástico e pegajoso, raízes comuns e fasciculadas finas comuns, bioporos milimétricos de formigas e de cupins. Raros pedotúbulos milimétricos, alguns revestimentos amarelos, porosidade de amontoamento dos agregados, porosidade fissural e biológica, predominando a porosidade tubular fina, transição abrupta plana.

3. No terço médio da vertente, apresenta cor cinza avermelhada escura (5YR 4/2), textura argilo-arenosa, com a presença de areia lavada, cor cinza-escura (10YR 4/1) e bruno escuro (10YR 4/2), com raízes finas, estrutura em blocos formando poliedros de $30 \mathrm{~mm}$ que se desfazem em estrutura granular ao leve toque dos dedos. Porosidade comum pequena a muito pequena, consistência seca solta, úmida é muito friável, e molhada, não plástica e ligeiramente pegajosa, transição gradual plana. No terço superior da vertente, onde há desmatamentos recentes e lavouras com 5 a 12 anos, as cores variam entre o amarelo brunado (10YR 6/8), bruna (10YR 5/3) e bruno pálido (10YR 6/3), textura argilo-arenosa, estrutura em blocos angulares médios a grandes (20-40 $\mathrm{mm}$ ) presença de poucos poros muito pequenos e poucos poros médios, consistência seca dura, úmida friável e molhada é ligeiramente plástico e pegajoso. Poucos nódulos de óxido de ferro, pequenos, duros, arredondados a angulares, cor vermelha $(2,5 \mathrm{YR} 4 / 8)$, transição gradual plana.

4. Horizonte de solo que se estende do terço inferior ao médio da vertente, com espessura média de $20 \mathrm{~cm}$, alcançando $40 \mathrm{~cm}$ no terço médio e 60 
$\mathrm{cm}$ no terço inferior, apresenta as cores brunas (10YR 5/3) e bruna acinzentada (10YR 5/2) com manchas grandes e irregulares de até 10 $\mathrm{cm}$ com cores bruno amareladas (10YR 5/6) e bruna acinzentada (10YR $5 / 2$ ), evidenciando hidromorfia, principalmente nas faces estruturais de grandes blocos, fendas e grandes fissuras. Apresenta também as cores bruna escura amarelada (10YR 4,5/1), bruna (10YR 5/3 e 7,5 YR 4/3), bruno escuro acinzentado (10YR 4/2), bruno amarelado (10YR 5/4), bruno acinzentado (10YR 5/2), cinza claro brunado (10YR 6/2), cinza claro (10YR 7/1), cinza (2,5Y 6/1 e 10YR 6/1) com zonas brancas (2,5Y 8/2) difusas e alongadas, textura argilosa, estrutura subangular moderada de 2-3 cm, que se desfaz em blocos arredondados de até $1 \mathrm{~cm}$ de diâmetro, estrutura prismática muito grande que se quebra em blocos subarredondados de 0,3-0,5 cm de diâmetro. A consistência seca é friável, molhada é plástica e pegajosa. Pedotúbulos comuns de 0,3-0,4 $\mathrm{cm}$ de diâmetro com material cinza como no horizonte anterior, nódulos vermelhos arredondados $\leq 0,5 \mathrm{~cm}$ esparsos e freqüentes, raras raízes fasciculadas finas, poros tubulares de cupins ou raízes $0,1-0,4 \mathrm{~cm}$, sendo os menores, porosidade do próprio solo, porosidade fissural fina dominante, presença de cupins e minhoca. Os nódulos vermelhos vistos com lupa são de material fino, aspecto compacto, denso, homogêneos, transição plana gradual.

5. Horizonte de solo que se estende do terço inferior ao terço médio da vertente, com espessura média de $80 \mathrm{~cm}$, apresentando a menor espessura cerca de $40 \mathrm{~cm}$, na base da vertente. Apresenta cores bruna e cinza em tons claros, tais como bruno muito pálido (10YR 8/3), cinza claro (10YR 7/2), bruno muito pálido (10YR 8/3), cinza claro brunado (10YR 6/2 e 2,5 Y 6/2), bruno pálido (10YR 6/3), bruno claro amarelado (10Y 6/4), bruno amarelado (10YR 5/4) e bruno acinzentado (10YR 5/2), com manchas amareladas, cor amarelo oliváceo (2,5YR 6/8) e bruno amarelado claro (2,5 YR 6/4), evidenciando hidromorfia, 
que vão se transformando em nódulos vermelhos, ligeiramente duros, arredondados ou subangulares, subcentimétricos. Ao iniciar o terço médio da vertente aumentam as concreções vermelhas (2,5YR 4/6), que passam da consistência macia para endurecida, alcançando no final terço médio uma proporção igual a da matriz. Possui textura argilosa, estrutura em blocos subangulares de aproximadamente $1 \mathrm{~cm}$, bem desenvolvidos, que desfaz em grânulos muito pequenos com leve pressão dos dedos, consistência seca solta a friável, consistência úmida firme mas deformável com a umidade, quando molhado a consistência do solo é plástica e pegajosa, presença de raízes e pedotúbulos de 0,5 a 3 cm de diâmetro, transição abrupta no terço inferior e gradual plana no terço médio.

6. Horizonte de solo que se estende do terço inferior ao terço médio da vertente, com espessura média de $80 \mathrm{~cm}$, apresenta cores claras que vão do branco (10YR 8/1 e 8/2), ao bruno muito pálido (10YR 8/3), cinza rosado (7,5YR 7/2), cinza claro (10YR 7/1) e bruno acinzentado (10YR $5 / 2$ ) com manchas amareladas (10YR 5/6). Textura argilosa a argilosiltosa, estrutura granular fraca pequena, aspecto maciço, coeso, grânulos de argila milimétricos, bem arredondados, compactos e mais coesos que a matriz, firmes, consistência molhada pegajosa e ligeiramente plástica, ausência de concreções ou nódulos vermelhos.

7. Horizonte de solo com espessura média de 1 metro, que ocorre exclusivamente na base da vertente, com cores muito claras, principalmente branca (10YR 8/1 e 2,5Y 8/1) e bruno pálido (10YR 6/3), textura argilosa. Distingue-se do anterior devido a cor mais clara, a posição com relação ao nível freático, bem como pela presença de uma camada centimétrica de areia fina que o separa do horizonte sobrejacente. 
8. Horizonte de solo que se estende por toda a vertente, constituindo a base da topossequência, geralmente apresenta cores claras iniciando com o branco (5Y 7/6) na base da vertente, com manchas amarelas e rosadas e presença de nódulos centimétricos, passando para bruno muito pálido (10YR 8/3) com zonas vermelhas aparentando colunas difusas quando passa para o terço médio e cores amareladas, tais como bruno muito pálido (10YR 7/4 e 6/6), amarelo brunado (10YR 7/7 e 6/6), bruno muito pálido (10YR 8/4,7/3 e 6/4), bruno muito pálido (10YR 6/3), bruno amarelado (10YR 6/4), amarelo brunado (10YR 6/6) e amarelo avermelhado (5YR 6/4), amarelo brunado (10YR 6/6) e amarelo avermelhado (5YR 6/8, 6/6 e 5/8) na parte mais superior da topossequência, com freqüentes concreções esféricas duras vermelhas (2,5YR 5/6). Textura argilosa, estrutura em blocos angulares médios, poucos poros médios, consistência seca macia, consistência úmida muito friável, e molhada é ligeiramente plástica e pegajosa. 


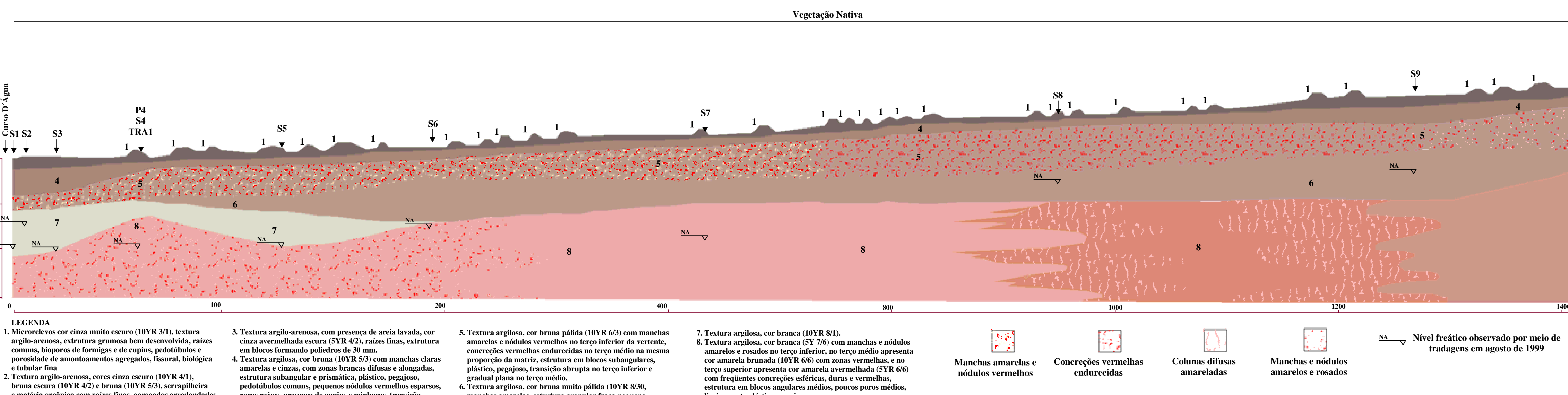

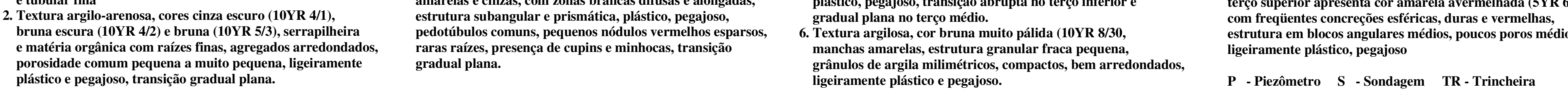

$\underset{\substack{\mathrm{p} 3 \\ \mathrm{TR} 2}}{\substack{\mathrm{L} 2 \\ 3}}$

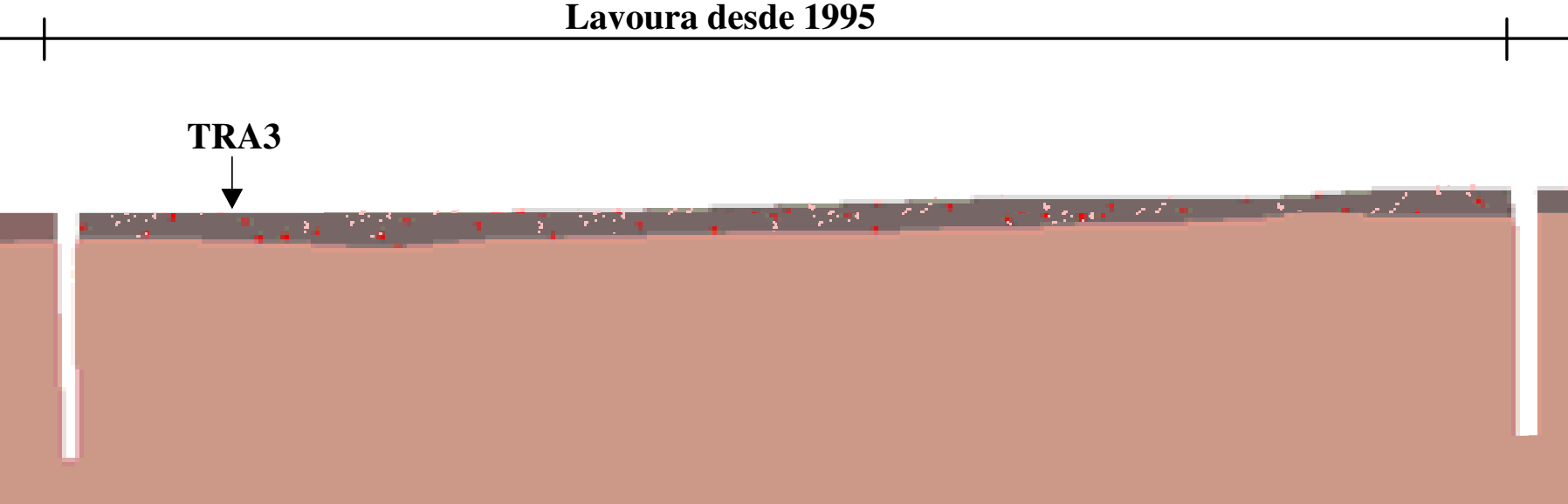

1

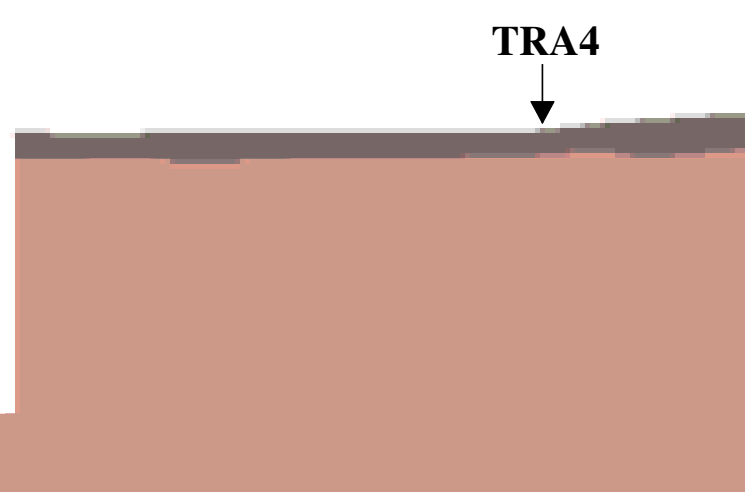

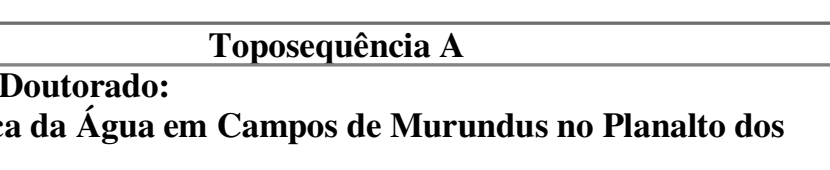

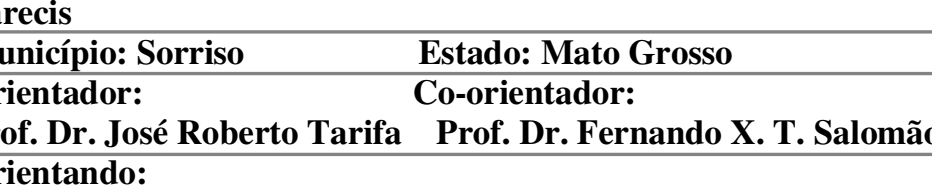

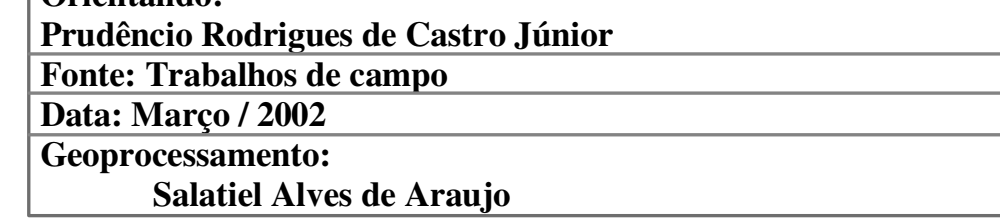




\subsubsection{Descrição das Trincheiras}

Para se chegar a representação da topossequência A foram abertas, descritas e amostradas 4 trincheiras, apresentadas neste capítulo, e 10 sondagens à trado ao longo da vertente, alinhadas na direção N115, apresentadas no anexo II.

\subsubsection{Trincheira A1}

A trincheira 1 (TRA1) localizada na base da vertente, a aproximadamente 100 metros do início, sua configuração e descrição é apresentada na figura $\mathrm{n}^{\circ} 10$, seu aspecto geral pode ser observado na fotografia $n^{\circ} 4$, apresenta os seguintes horizontes:

1. Horizonte de solo com $10 \mathrm{~cm}$ de espessura aproximadamente, cor cinza escuro (10YR 4/1), algumas manchas mais claras em 6/1 e algumas amarelas em 6/6, textura argilo-arenosa, estrutura grumosa bem desenvolvida, torrões de 2 a $3 \mathrm{~cm}$ que se desfazem em agregados de até 1 $\mathrm{mm}$. Consistência seca é dura, quando úmido e ligeiramente friável ou macio, e molhado é plástico e pegajoso, raízes comuns e fasciculadas finas comuns, bioporos milimétricos de formigas e de cupins. Apresenta algumas feições pedológicas, tais como raros pedotúbulos milimétricos, alguns revestimentos amarelos, porosidade de amontoamento dos agregados, porosidade fissural e porosidade biológica (cupim, minhoca e formiga), além de porosidade tubular fina que predomina dentre as demais, transição abrupta plana. 


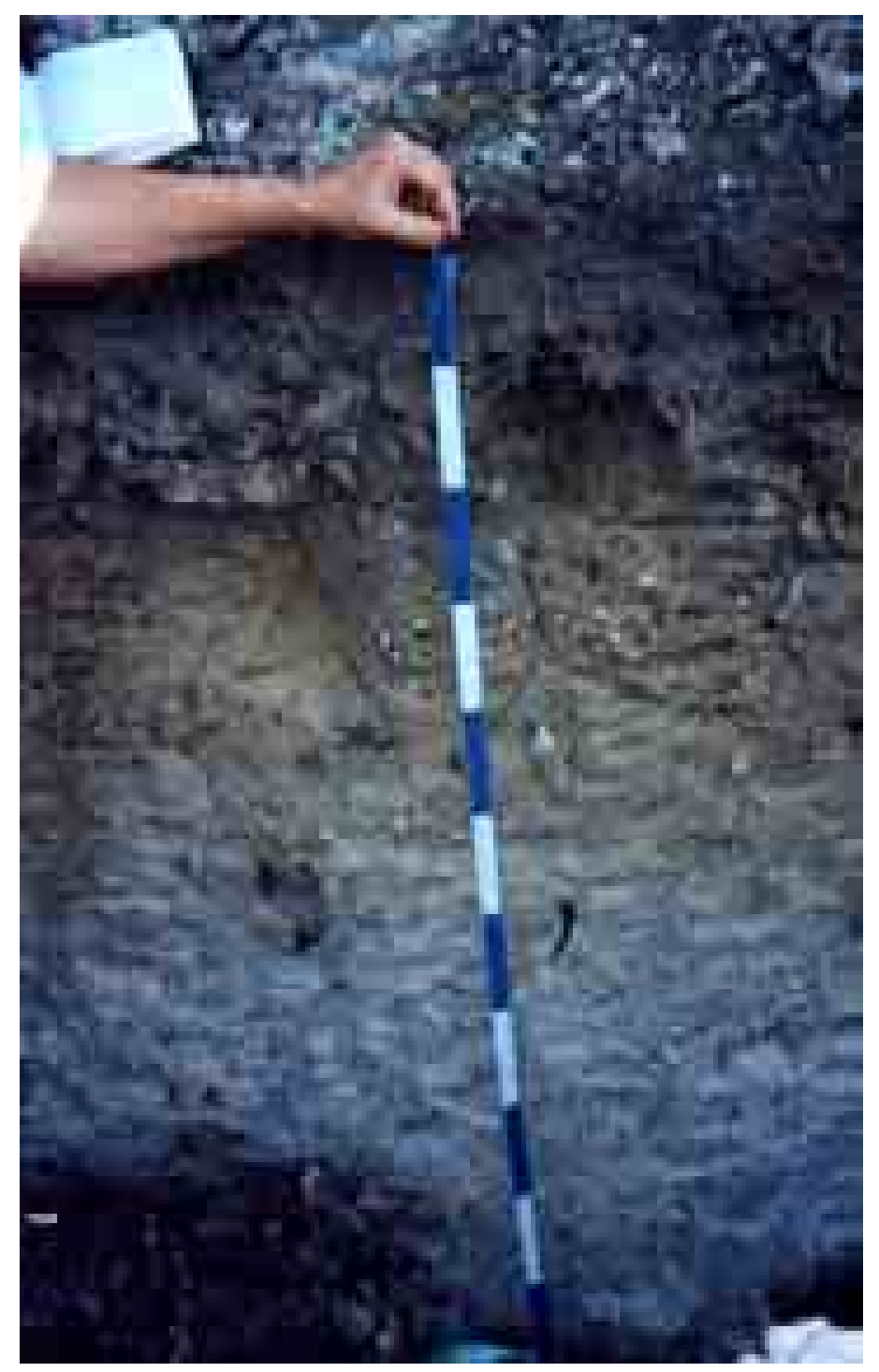

Fotografia $n^{\circ}$ 4, Trincheira TRA1(Castro-Junior-1999)
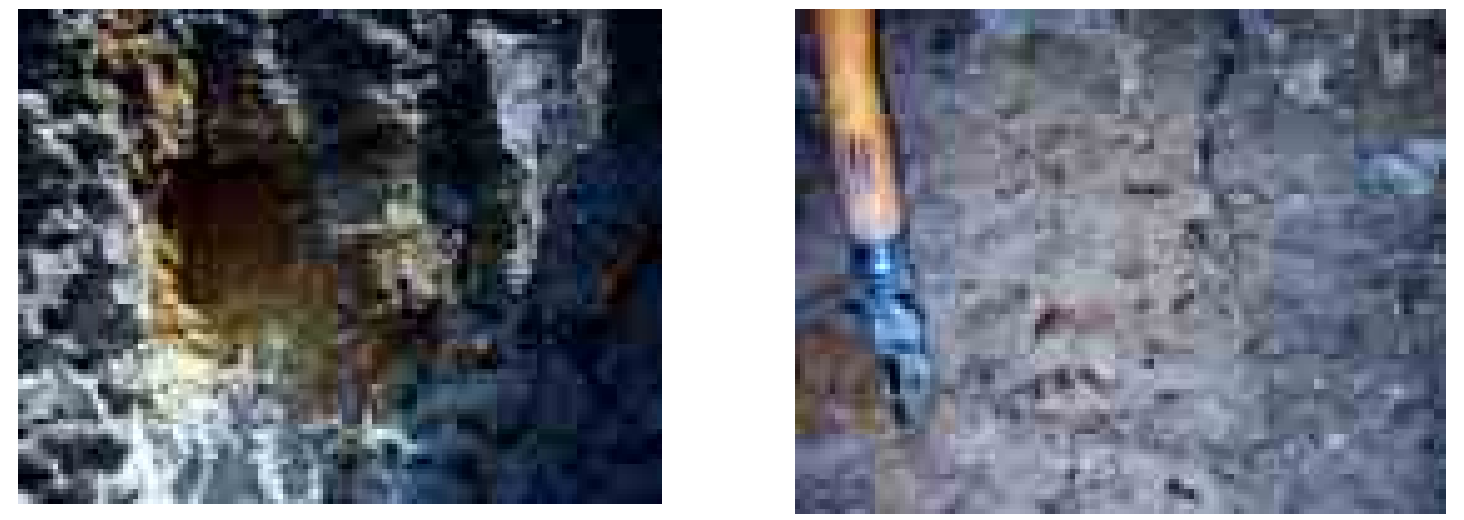

Detalhes de Gleização da Trincheira TRA1 


\section{Figura $n^{\circ} 10$ - Configuração esquemática da trincheira TRA1}

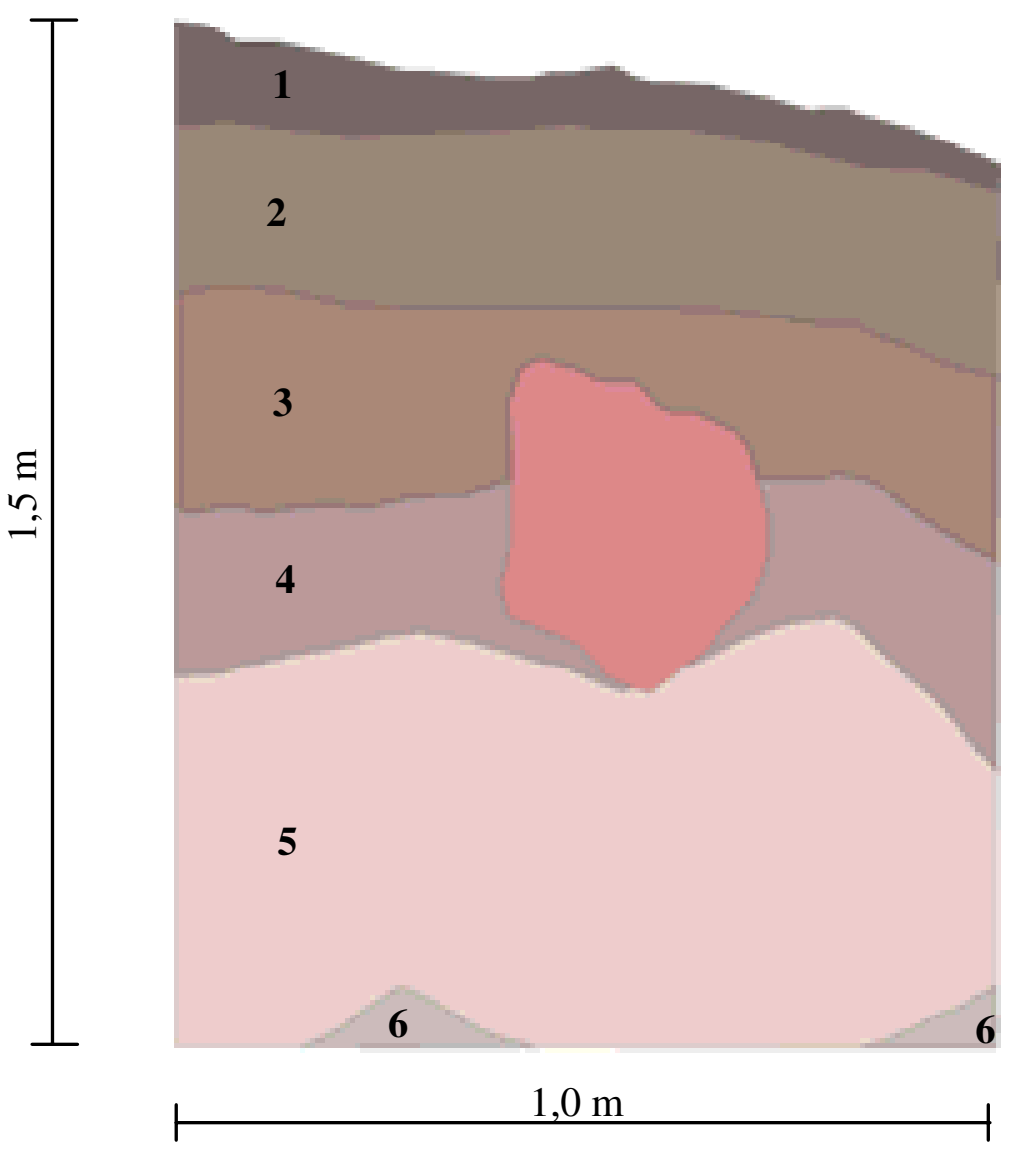

1. Cor cinza escuro (10YR 4/1), algumas manchas mais claras em 6/1 e algumas amarelas em 6/6, textura argilo-arenosa, estrutura grumosa bem desenvolvida, torrões de 2 a $3 \mathrm{~cm}$ que se desfazem em agregados de até $1 \mathrm{~mm}$, consistência seca dura, úmida é ligeiramente friável ou macia, e molhada é plástica e pegajosa, raízes comuns e fasciculadas finas comuns, bioporos milimétricos de formigas e de cupins.

2. Cor bruna acinzentada (10YR 5/2) com manchas amarelas 5/6, textura argilopouco arenosa, estrutura subangular $2-3 \mathrm{~cm}$ moderada, consistência seca friável, quando molhada apresenta comportamento plástico e pegajoso, nódulos arredondados na base do horizonte, pedotúbulos comuns.

3. Cor bruna (10YR 5/3) com manchas amarelas e cinzentas (5/2), textura argiloarenosa, estrutura prismática muito grande que quebra em blocos subarredondados e subangulares, bem desenvolvidos, consistência seca firme, úmida friável, e quando molhada a amostra de solo apresenta comportamento plástico e pegajoso, pedotúbulos comuns, nódulos vermelhos arredondados $\leq 0,5$ $\mathrm{cm}$ esparsos e freqüentes, raras raízes fasciculadas finas.

4. Cor cinza brunado claro (2,5Y 6/2) com manchas amarelo oliváceo (2,5YR 6/8), textura argilosa, diminuindo muito a sensação de areia fina, estrutura em blocos subangulares mais ou menos $1 \mathrm{~cm}$, bem desenvolvidos, consistência úmida firme mas deformável com umidade; quando molhado, a consistência do solo é plástica e pegajosa.

5. Cor branca a cinza clara (10YR $8 / 2)$ dominante que vai clareando para a base para a cor branca $(2,5 \mathrm{Y} 8 / 2)$ com zonas amarelo-brunado (10YR 6/8) e amarelas $(2,5 \mathrm{Y} 7 / 8)$, textura muito argilosa, estrutura em blocos angulares de $3-5 \mathrm{~cm}$, muito coesos pela umidade, consistência úmida firme mas deformável devido a umidade, consistência molhada muito plástica, muito pegajosa, nódulos vermelhos (2,5YR 4/8), ligeiramente duros a macios e friáveis, centimétricos, comuns, aleatórios, poros tubulares de $2-4 \mathrm{~mm}$ de raízes e do solo.

6. Horizonte de solo que inicia aos $106 \mathrm{~cm}$ de profundidade, observável apenas na base da face sul da trincheira, Cor cinza claro (10YR 7/1) homogêneo com raras argilo-siltosa, estrutura granular fraca pequena, aspecto maciço coeso; grânulos de argila milimétricos, bem arredondados, compactos e mais secos que a matriz, firmes; muito pegajoso e ligeiramente plástico; presença de areia muito fina ou silte.

Observações da face sul

Volumes 2 e 3 são mais espessos.

Os agregados do volume 2 são melhor definidos, bem individualizados, presos apenas pelas raízes; a cor é bruna acinzentada, mais clara que na face sul, onde se apresenta com as colorações bruno acinzentado (10YR 5/2) e bruno acinzentado claro (10YR 4/2) com mais manchas bruno amarelas (10YR 5/6) que o da face leste 
2. Horizonte de solo com $16 \mathrm{~cm}$ de espessura aproximadamente, que inicia entre 6-12 cm de profundidade, cor bruno acinzentado (10YR 5/2) com manchas amareladas em 5/6, textura argilo-pouco arenosa, estrutura subangular 2-3 cm moderada, desfaz em blocos arredondados de até 1 $\mathrm{cm}$ de diâmetro, bem desenvolvidos, duros, consistência seca friável, quando molhada apresenta comportamento plástico e pegajoso, poucas películas amareladas milimétricas a no máximo $1 \mathrm{~cm}$, nítidos volumes de mesmo tamanho, nódulos arredondados na base do horizonte, pedotúbulos comuns com diâmetro menor a igual $1 \mathrm{~cm}$ preenchidos por material orgânico cinza escuro fino, raízes fasciculadas milimétricas finas, poros tubulares freqüentes $0,1-0,3 \mathrm{~mm}$, porosidade fissural fina dominante (arranjo dos agregados) poucos canais de cupins, presença de aglomerados de cupins ainda com canais preservados, com transição abrupta plana.

3. Horizonte de solo com $25 \mathrm{~cm}$ de espessura aproximadamente, que inicia entre 22-34 $\mathrm{cm}$ de profundidade, matriz com coloração bruna (10YR $5 / 3$ ) com manchas amarelas e cinzentas (5/2) como no anterior (Foto 11) evidenciando hidromorfia, grandes (até $10 \mathrm{~cm}$ ) irregulares, principalmente nas faces estruturais de grandes blocos, fendas e grandes fissuras, textura argilo-arenosa, estrutura prismática muito grande que quebra em blocos subarredondados e subangulares $0,3-0,5 \mathrm{~cm}$ de diâmetro, bem desenvolvidos, consistência seca firme, úmida friável, e quando molhada a amostra de solo apresenta comportamento plástico e pegajoso, pedotúbulos comuns de 0,3-0,4 cm de diâmetro com material cinza como no horizonte anterior, nódulos vermelhos arredondados $\leq$ $0,5 \mathrm{~cm}$ esparsos e freqüentes, raras raízes fasciculadas finas, poros tubulares de cupins ou raízes $0,1-0,4 \mathrm{~cm}$, sendo os menores, porosidade do próprio solo, porosidade fissural fina dominante, presença de fendas 
verticais provavelmente conseqüência da abertura da trincheira, presença de cupins e minhoca, os nódulos vermelhos vistos com lupa são de material fino, aspecto compacto, denso, homogêneos (foto 12) (foto 13), transição plana gradual marcada principalmente pelo aumento notável e crescente de argila e umidade, além do clareamento da cor até ficar cinza claro.

4. Horizonte de solo com espessura de $24 \mathrm{~cm}$ aproximadamente, que inicia entre 35-64 $\mathrm{cm}$ de profundidade, matriz com coloração cinza brunado claro $(2,5 \mathrm{Y} 6 / 2)$ com manchas amarelas às vezes grandes com coloração amarelo oliváceo (2,5YR 6/8), com limites difusos nas paredes estruturais e coloração bruno amarelado claro (2,5YR 6/4) mas que diminuem em freqüência e diâmetro tornando-se mais difíceis e menos contrastados, essas manchas desaparecem na base do horizonte, textura argilosa, diminuindo muito a sensação de areia fina, estrutura em blocos subangulares de mais ou menos $1 \mathrm{~cm}$, bem desenvolvidos, consistência úmida firme mas deformável com umidade, quando molhado, a consistência do solo é plástica e pegajosa, transição plana e abrupta.

5. Horizonte de solo de espessura de $50 \mathrm{~cm}$ aproximadamente, que inicia entre $60-80 \mathrm{~cm}$ de profundidade, matriz de cor cor branca a cinza clara (10YR 8/2) dominante que vai clareando para a base para a cor branca $(2,5 \mathrm{Y} 8 / 2)$ com zonas, algumas manchas amarelo brunado (10YR 6/8) e amarelas $(2,5 \mathrm{Y} 7 / 8)$ difusas de contraste fraco de difícil avaliação de dimensão, textura muito argilosa, estrutura em blocos angulares de 3-5 $\mathrm{cm}$, muito coesos pela umidade, consistência úmida firme mas deformável devido a umidade, consistência molhada muito plástica, muito pegajosa, nódulos vermelhos (2,5YR 4/8), ligeiramente duros a macios e friáveis, centimétricos, comuns, aleatórios, poros tubulares de 2-4 $\mathrm{mm}$ de raízes e do solo; sem raízes. $\mathrm{O}$ aspecto geral devido a 
umidade é de maciço coeso, onde ressaltam-se os nódulos vermelhos no fundo cinza claro, transição gradual.

6. Horizonte de solo que inicia aos $106 \mathrm{~cm}$ de profundidade, observável apenas na base da face sul da trincheira, Cor cinza claro (10YR 7/1) homogêneo textura argilo-siltosa, estrutura granular fraca pequena, aspecto maciço coeso, grânulos de argila milimétricos, bem arredondados, compactos e mais secos que a matriz, firmes, muito pegajoso e ligeiramente plástico, presença de areia muito fina ou silte.

\subsubsection{Trincheira A2}

A trincheira 2 (TRA2), localizada no terço médio da vertente, na parte final do campo de murundus, a aproximadamente 1480 metros do início, sua configuração e descrição é apresentada na figura $\mathrm{n}^{\circ} 11$, seu aspecto geral pode ser observado na fotografia $\mathrm{n}^{\circ} 5$, apresenta os seguintes horizontes:

1. Horizonte de solo com $10 \mathrm{~cm}$ de espessura, cor cinza avermelhado escuro (5YR 4/2), textura argilo-arenosa, estrutura em blocos formando poliedros de $3 \mathrm{~cm}$, que se desfazem em estrutura granular ao leve toque dos dedos. Porosidade comum, pequena a muito pequena. Consistência seca solta, úmida muito friável, e molhado o solo apresenta comportamento não plástico e ligeiramente pegajoso, transição gradual plana.

2. Horizonte de solo com $22 \mathrm{~cm}$ de espessura, que inicia entre $8-10 \mathrm{~cm}$ de profundidade, cor bruno pálido (10YR 6/3) quando seca e bruno amarelado claro (10YR 6/4) quando úmida, textura argilo-siltosa, estrutura em blocos angulares de $1 \mathrm{~cm}$ em média, que se desfaz em grânulos muito pequenos ao toque entre os dedos, porosidade muito pequena, consistência dura seca, úmida friável, e molhada apresenta comportamento plástico e pegajoso, nódulos de óxido de ferro 


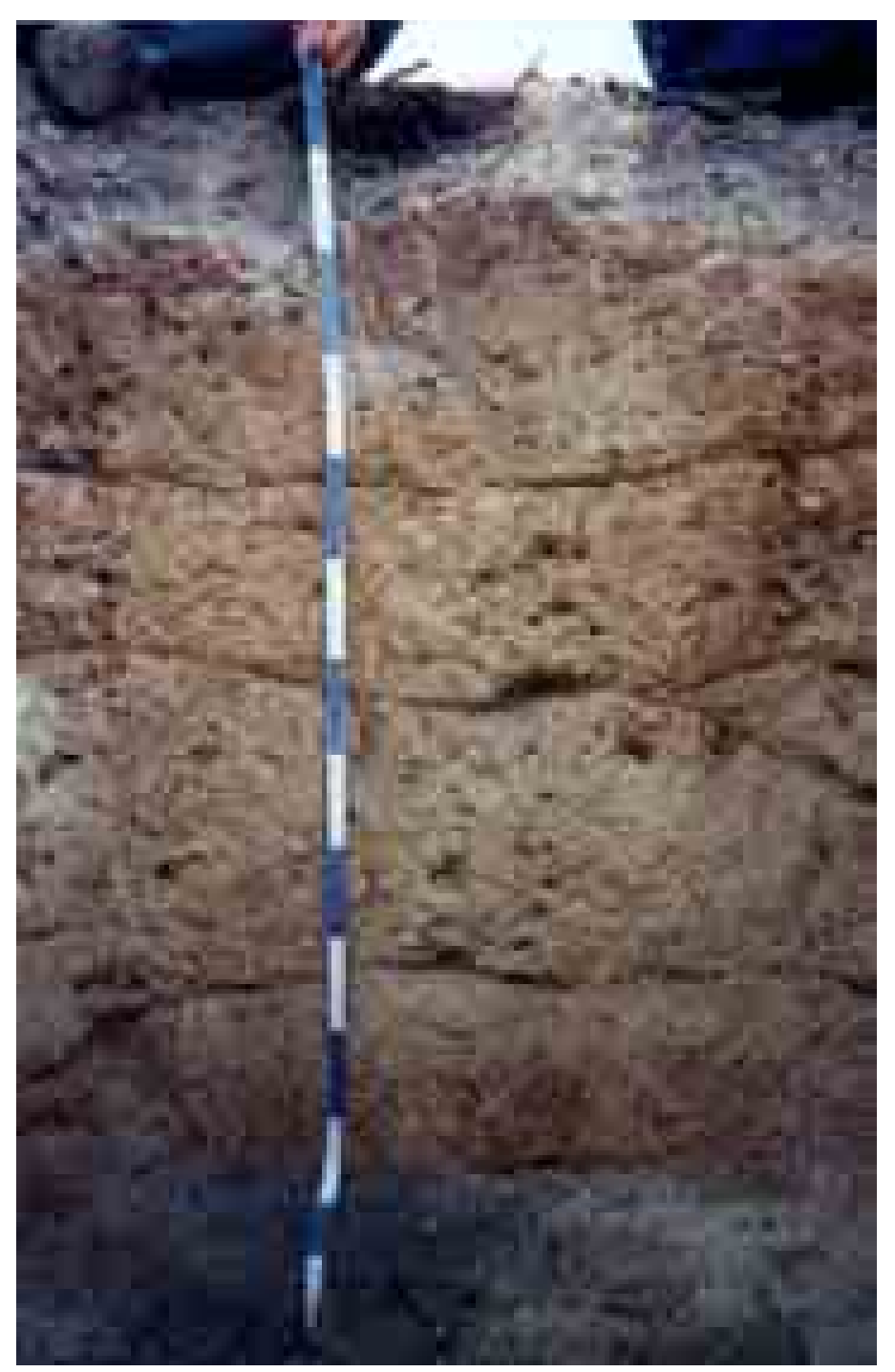

Fotografia $n^{\circ} 5$ Trincheira TRA2(Castro-Junior, 1999) 


\section{Figura $n^{\circ} 11$ - Configuração esquemática da trincheira TRA2}

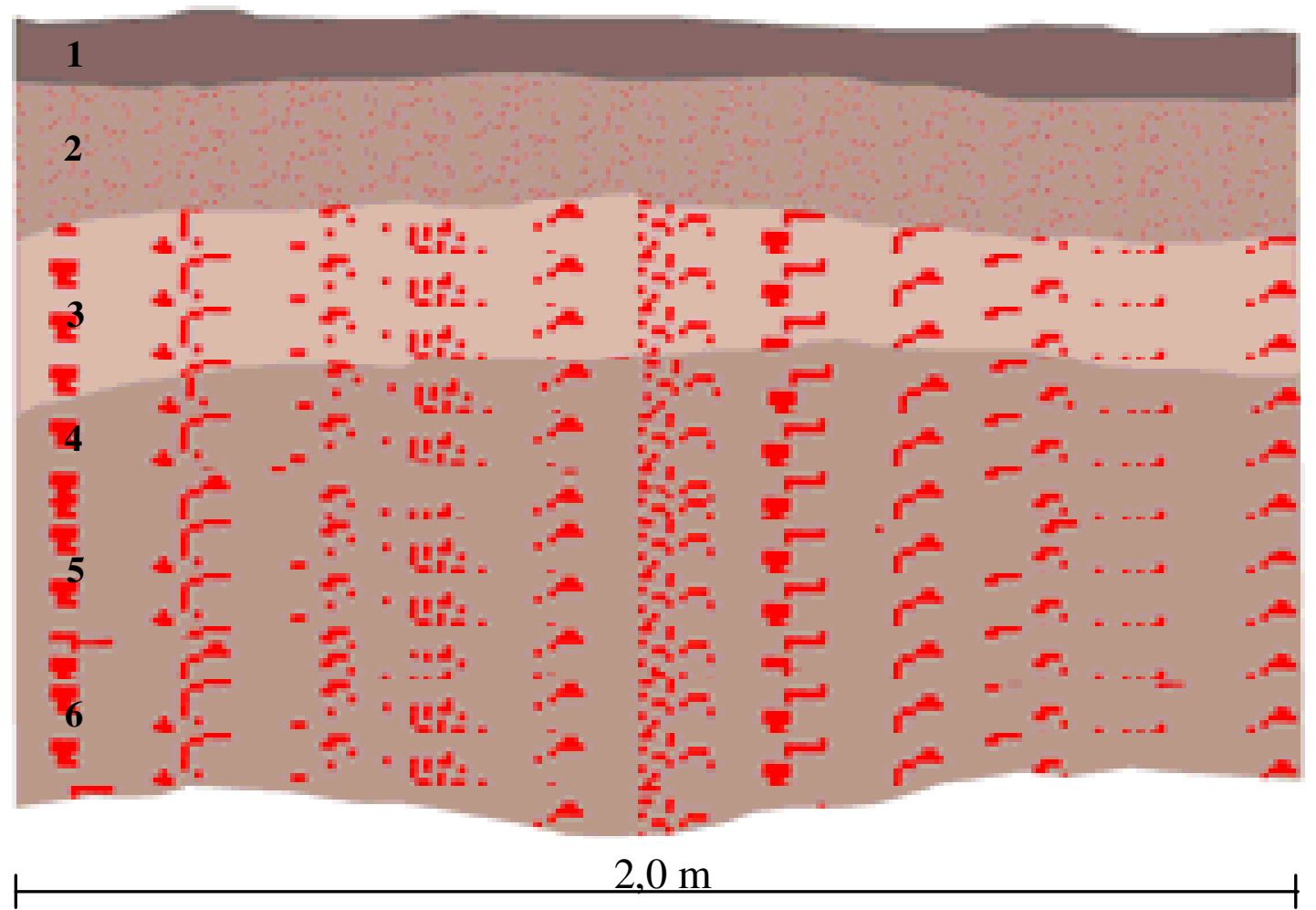

1. Cor cinza avermelhado escuro (5YR 4/2), textura argilo-arenosa, estrutura em blocos formando poliedros de $3 \mathrm{~cm}$. Porosidade comum, pequena a muito pequena. Consistência seca solta, úmida muito friável, e molhado o solo apresenta comportamento não plástico e ligeiramente pegajoso.

2. Horizonte de solo com $22 \mathrm{~cm}$ de espessura, que inicia entre $8-10 \mathrm{~cm} \mathrm{de}$ profundidade, cor bruno pálido (10YR 6/3) quando seca e bruno amarelado claro (10YR 6/4) quando úmida, textura argilo-siltosa, estrutura em blocos angulares de $1 \mathrm{~cm}$ em média, que se desfaz em grânulos muito pequenos ao toque entre os dedos, porosidade muito pequena, consistência dura seca, úmida friável, e molhada apresenta comportamento plástico e pegajoso, nódulos freqüentes, pequenos e duros, formato irregular, cor vermelha (2,5YR 5/8), óxido de ferro, transição gradual plana.

3. Cor bruna muito pálida (10YR 7/3), textura argilo-siltosa, estrutura colunar média, poros comuns, muito pequenos, porosidade capilar, consistência seca ligeiramente dura, quando úmida é friável, molhado apresenta consistência ligeiramente plástica e pegajosa, nódulos freqüentes, duros, irregulares, cor vermelha (2,5YR 5/8), óxido de ferro.

4. Cor bruna pálida (10YR 6/3), textura argilosa, estrutura em blocos angulares grandes, muitos poros muito pequenos, consistência seca não coerente ou friável, quando molhado é compacto consistência molhada plástica e ligeiramente pegajosa, presença de pedotúbulos de 0,5 a $3 \mathrm{~cm}$ de diâmetro, nódulos frequientes, pequenos, duros, cor vermelha.

5. Cor bruna pálida (10YR 6/3) com manchas amareladas, textura argilosa, estrutura em blocos angulares grandes, muitos poros pequenos, consistência seca solta, úmida extremamente firme e compacta e molhada apresenta comportamento plástico e ligeiramente pegajoso, nódulos de cor vermelho amarelado (5YR 5/8), freqüentes, grandes, duros e irregulares, composto de óxido de ferro.

6. Cor bruna pálida (10YR 6/3), textura argilosa, estrutura em blocos angulares médios, presença de poros comuns, poros pequenos e porosidade capilar, consistência seca solta, úmida muito friável e compacto e molhado é plástico e ligeiramente pegajoso. Nódulos muito freqüentes, duros, irregulares, grandes, vermelho amarelados. 
4. Horizonte de solo com $25 \mathrm{~cm}$ de espessura, que inicia entre $45-50 \mathrm{~cm}$ de profundidade, cor bruno pálido (10YR 6/3) seca e úmida, textura argilosa, estrutura em blocos angulares grandes, muitos poros muito pequenos, consistência seca não coerente ou friável, quando molhado é compacto consistência molhada plástica e ligeiramente pegajosa, fracamente cimentado, presença de pedotúbulos de 0,5 a $3 \mathrm{~cm}$ de diâmetro, nódulos freqüentes, pequenos, duros, cor vermelha $(2,5 \mathrm{YR}$ 5/8) e vermelha amarelada (5YR 5/8), transição gradual plana.

5. Horizonte de solo com $30 \mathrm{~cm}$ de espessura, que inicia entre $65-74 \mathrm{~cm}$ de profundidade, com maior umidade que o anterior, apresenta manchas amareladas, cor bruno pálido (10YR 6/3) com manchas amareladas, textura argilosa, estrutura em blocos angulares grandes, muitos poros pequenos, consistência seca solta, úmida extremamente firme e compacta e molhada apresenta comportamento plástico e ligeiramente pegajoso, nódulos de óxido de ferro de cor vermelha amarelada (5YR 5/8), freqüentes, grandes, duros e irregulares, transição gradual plana.

6. Horizonte de solo com $25 \mathrm{~cm}$ de espessura, que inicia entre $95 \mathrm{~cm}$ de profundidade, cor bruno pálido (10YR 6/3), textura argilosa, estrutura em blocos angulares médios, presença de poros comuns, poros pequenos e porosidade capilar, consistência seca solta, úmida muito friável e compacto, quando molhado é plástico e ligeiramente pegajoso. Nódulos muito freqüentes, duros, irregulares, grandes, cor vermelho amarelado (5YR 5/8), transição não observável.

\subsubsection{Trincheira A3}

A trincheira 3 (TRA3), localizada no terço superior da vertente, a aproximadamente 1840 metros do início da vertente, onde se pratica 
lavoura de soja desde 1997, sua configuração e descrição é apresentada na figura $\mathrm{n}^{\circ} 12$, seu aspecto geral pode ser observado na fotografia $\mathrm{n}^{\circ} 6$, apresenta os seguintes horizontes:

1. Horizonte de solo $10 \mathrm{~cm}$ com espessura aproximadamente, cor amarelo brunado (10YR 6/8 seco), e bruno (10YR 5/3 úmido), textura argilosiltosa, estrutura em blocos angulares grandes $(4 \mathrm{~cm})$ muito coesos, presença de poucos poros muito pequenos, consistência seca dura, úmida friável, e molhada é ligeiramente plástico e ligeiramente pegajoso, nódulos muito poucos, pequenos, duros, esféricos, cor vermelha (2,5YR 4/8), constituído de óxido de ferro.

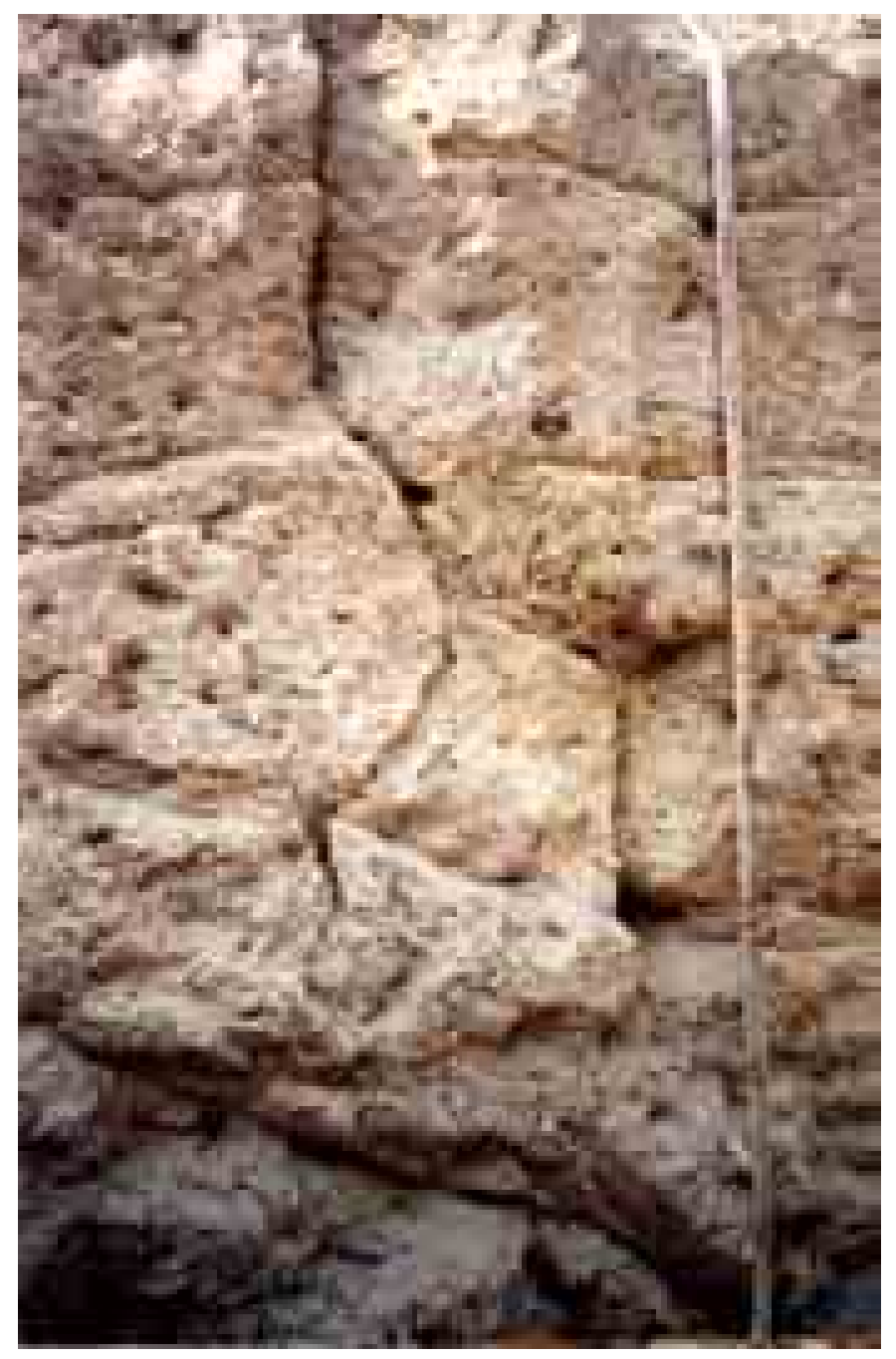

Fotografia $n^{\circ}$ 6: Trincheira TRA3(Castro-Junior, 1999) 


\section{Figura nº 12 - Configuração esquemática da trincheira TRA3}

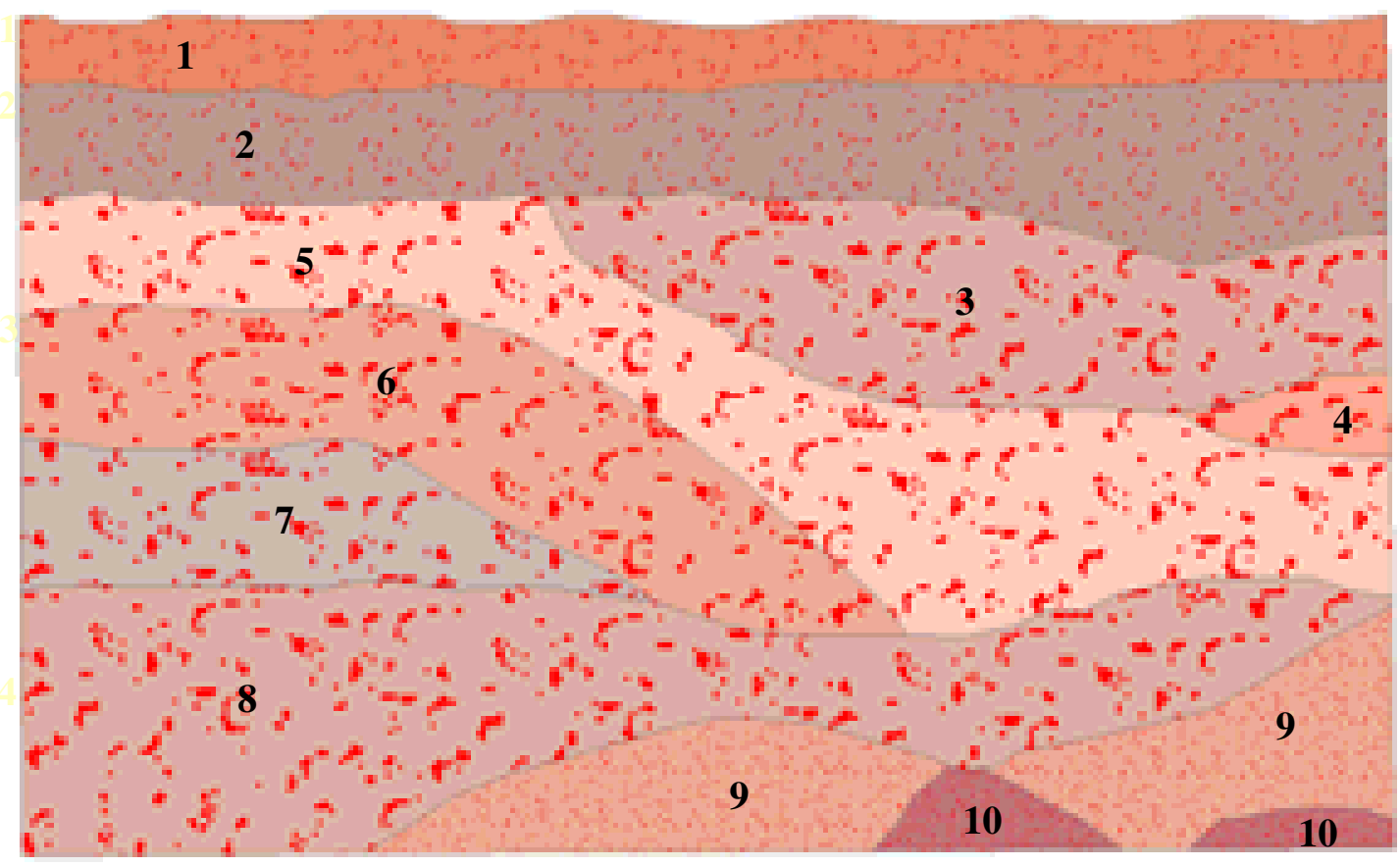

1. Cor amarelo brunado (10YR 6/8), textura argilo-siltosa, estrutura em blocos angulares grandes, muito coesos, presença de poucos poros muito pequenos, consistência seca dura, úmida friável e molhada é ligeiramente plástico e ligeiramente pegajoso, nódulos muito poucos, pequenos, duros, esféricos, vermelhos.

2. Cor bruna muito pálida (10YR 6/3), textura argilosa, estrutura em blocos angulares grandes, muitos poros pequenos, consistência seca ligeiramente dura, úmida solta, e molhada é ligeiramente plástica e ligeiramente pegajosa, nódulos muito poucos, pequenos, duros, cor vermelhos.

3. Cor bruna muito pálida (10YR 7/4), textura argilosa, estrutura em blocos angulares médios, poros comuns, pequenos, consistência seca ligeiramente duro, úmida friável, e molhada é ligeiramente plástica e ligeiramente pegajosa, nódulos freqüentes, grandes, irregulares, duros, vermelhos.

4. Horizonte de solo com $10 \mathrm{~cm}$ de solo aproximadamente, que inicia entre 50-57 $\mathrm{cm}$ de profundidade, cor amarela , quando seca (10YR 7/4) e úmida, amarelo brunado (10YR 7/7), textura argilo-siltosa, estrutura de blocos irregulares grandes, presença de muitos poros pequenos, consistência seca ligeiramente duro, úmido é friável, e molhado é ligeiramente plástico e ligeiramente pegajoso, nódulos freqüientes, grandes $(2-3 \mathrm{~cm})$, duros, vermelhos $(2,5 \mathrm{YR} 4 / 8)$, óxido de ferro, irregulares.

5. Cor bruna muito pálida (10YR 8/4), textura: argilo-siltosa, estrutura blocos angulares grandes, pequenos poros comum, consistência molhada ligeiramente plástica e ligeiramente pegajosa, nódulos freqüentes, grandes, irregulares, vermelhos.

6. Cor amarela (10YR 7/6), textura argilosa, estrutura em blocos angulares médios, muitos poros pequenos a médios, consistência seca ligeiramente dura, úmida é friável, e molhada é ligeiramente plástica e ligeiramente pegajosa, nódulos freqüentes, grandes, duros, irregulares, vermelhos.

7. Cor cinza claro (10YR 7/2), textura argilosa, estrutura em blocos angulares médios, muitos poros pequenos a médios, consistência seca muito dura, úmida muito friável, molhada é ligeiramente plástica e ligeiramente pegajosa, nódulos freqüentes, grandes, duros, irregulares, vermelhos e amarelos.

8. Cor bruna muito pálida (10YR 7/4) com aspecto mosqueado, textura argilosa, estrutura blocos irregulares médios, muitos poros médios, consistência úmida solta, molhada é ligeiramente plástica e ligeiramente pegajosa, nódulos muito freqüentes, grandes, duros, irregulares, vermelhos e amarelos. 
2 Horizonte de solo com $15 \mathrm{~cm}$ de solo aproximadamente, que inicia a 10 $\mathrm{cm}$ de profundidade, cor bruno muito pálido (10YR 6/3 seca) e amarelo brunado (10YR 5/4 úmida), textura argilo-siltosa, estrutura em blocos angulares grandes, presença de muitos poros pequenos, consistência seca ligeiramente dura, úmido apresenta consistência solta, e molhado é ligeiramente plástico e ligeiramente pegajoso, muito poucos nódulos de óxido de ferro, pequenos, duros, vermelhos, transição gradual plana.

3. Horizonte de solo com $30 \mathrm{~cm}$ de solo aproximadamente, que inicia entre 25-35 $\mathrm{cm}$ de profundidade, cor bruno muito pálido (10YR 7/4 seca e 10YR 6/6 úmida), textura argilosa, estrutura em blocos angulares médios, poros comuns, pequenos, consistência seca ligeiramente dura, úmida é friável, e molhada é ligeiramente plástico e ligeiramente pegajoso, nódulos de óxidos de ferro freqüentes, grandes, irregulares, duros, vermelhos, transição gradual ondulada.

4. Horizonte de solo com $10 \mathrm{~cm}$ de solo aproximadamente, que inicia entre $50-57 \mathrm{~cm}$ de profundidade, cor amarela, quando seca (10YR 7/4) e úmida, amarelo brunado (10YR 7/7), textura argilosa, estrutura de blocos irregulares grandes, presença de muitos poros pequenos, consistência seca ligeiramente dura, úmida é friável, e molhada é ligeiramente plástica e ligeiramente pegajosa, nódulos de óxido de ferro freqüentes, grandes $(2-3 \mathrm{~cm})$, duros, vermelhos, irregulares, transição gradual ondulada.

5. Horizonte de solo com $20 \mathrm{~cm}$ de solo aproximadamente, que inicia entre 25-62 $\mathrm{cm}$ de profundidade, cor bruno muito pálido (10YR 8/4 seco e 10YR 7/3 úmido), textura: argilo-siltosa, estrutura blocos angulares grandes, presença de pequenos poros comum, consistência molhada ligeiramente plástica e ligeiramente pegajosa, nódulos de óxido de ferro 
freqüentes, grandes $(2 \mathrm{~cm})$, irregulares, vermelhos, transição gradual plana.

6. Horizonte de solo com $20 \mathrm{~cm}$ de espessura aproximadamente, que inicia entre 41-70 cm de profundidade, cor amarela (10YR 7/6 seca e 10YR 6/6 úmida), textura argilosa, estrutura em blocos angulares médios, muitos poros pequenos a médios, consistência seca ligeiramente dura, quando úmida é friável, e molhada é ligeiramente plástica e ligeiramente pegajosa, nódulos de óxido de ferro freqüentes, grandes, duros, irregulares, vermelhos, transição gradual plana.

7. Horizonte de solo com $20 \mathrm{~cm}$ de espessura aproximadamente, que inicia entre $60 \mathrm{~cm}$ de profundidade, cor cinza claro (10YR 7/2 seca 10YR 6/4 úmida), textura argilosa, estrutura em blocos angulares médios, presença de muitos poros pequenos a médios, consistência seca muito dura, úmida muito friável, e molhado é ligeiramente plástico e ligeiramente pegajoso, nódulos de óxido de ferro freqüentes, grandes, duros, irregulares, vermelhos e amarelos, transição gradual plana.

8. Horizonte de solo com $30 \mathrm{~cm}$ de espessura aproximadamente, que inicia entre $80-88 \mathrm{~cm}$ de profundidade, cor bruno muito pálido (10YR 7/4) com aspecto mosqueado, apresentando também cor bruna clara amarelada (10YR 6/4), textura argilosa, estrutura em blocos irregulares médios, presença de muitos poros médios, consistência úmida solta, molhada é ligeiramente plástica e ligeiramente pegajosa, nódulos de óxido de ferro muito freqüentes, grandes, duros, irregulares, vermelhos e amarelos, transição gradual plana.

9. Horizonte de solo que inicia aos $100 \mathrm{~cm}$ de profundidade, cor amarela (10YR 7/6 seca) e amarelo brunado (10YR 6/8 úmida), mosqueada, textura argilosa, estrutura granular, grânulos médios, presença de muitos poros grandes, consistência úmida solta, molhada é plástica e pegajosa, 
nódulos de óxido de ferro freqüentes pequenos $(1 \mathrm{~cm})$, duros, arredondados, vermelho, transição gradual plana.

10. Horizonte de solo que inicia aos $144 \mathrm{~cm}$ de profundidade, cor vermelha (2,5YR 5/8 seca e 4/8 úmida), textura argilosa, estrutura granular média, poros comuns pequenos, consistência úmida solta, e molhada é plástica e pegajosa, nódulos de óxido de ferro muito freqüentes, pequenos, duros, vermelhos, transição não observável.

\subsubsection{Trincheira A4}

A trincheira A 4, (TRA4), localizada na porção superior da vertente, onde se planta soja desde 1988, sua configuração e descrição é apresentada na figura $n^{\circ} 13$, seu aspecto geral pode ser observado na fotografia $n^{\circ} 7$, apresenta os seguintes horizontes:

1. Horizonte de solo com $15 \mathrm{~cm}$ de espessura aproximadamente, cor bruna pálida (10YR 6/3 seca) e bruna (10YR 5/3 úmida), textura argilo-siltosa, estrutura em blocos angulares médios, presença de poucos poros médios, consistência seca dura, úmida muito firme, e quando molhada apresenta consistência não plástica e ligeiramente pegajosa, poucos nódulos de óxido de ferro, pequenos, duros, arredondados a angulares, vermelhos, transição gradual plana.

2. Horizonte de solo com $10 \mathrm{~cm}$ de espessura aproximadamente, iniciando entre 11-23 cm, cor bruno muito pálido (10YR 7/3 (seca) e amarelo brunado (10YR 6/6 úmida), textura argilosa, estrutura em blocos angulares médios, presença de poros comuns tamanho médio, consistência seca dura, úmida friável, e molhada é ligeiramente plástico e ligeiramente pegajoso, nódulos de óxido de ferro freqüentes, pequenos, duros, arredondados, vermelhos, transição gradual plana. 
3. Horizonte de solo com $20 \mathrm{~cm}$ de espessura aproximadamente, iniciando entre $23-27 \mathrm{~cm}$, cor bruno pálido (10YR 6/3 seca) e amarelo brunado (10YR 6/6 úmida), textura argilosa, estrutura em blocos angulares médios, presença de poucos poros médios, consistência seca macia, muito friável (úmido), ligeiramente plástico e ligeiramente pegajoso, nódulos de óxido de ferro freqüentes, pequenos, duros, esféricos, vermelhos, transição gradual plana.

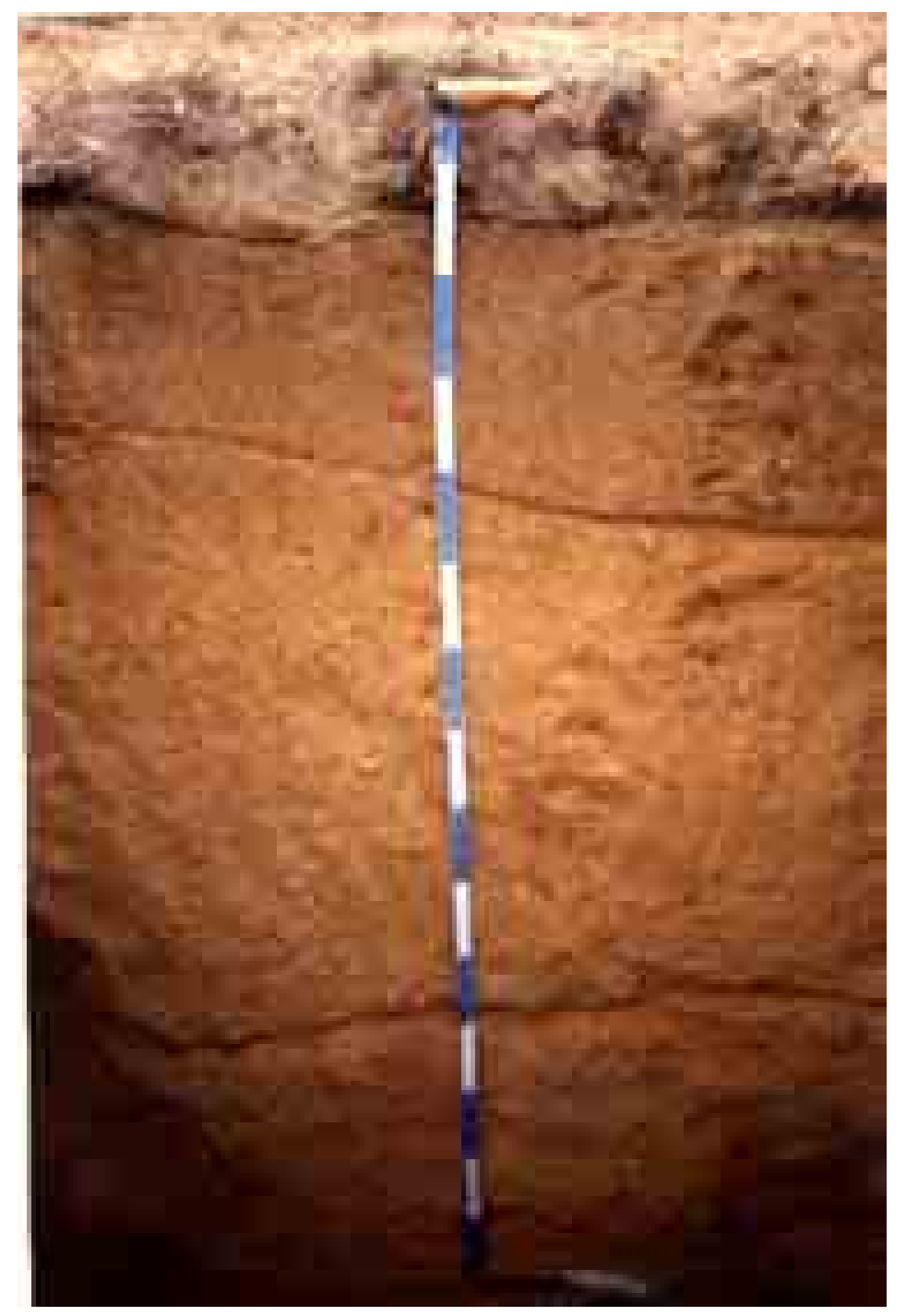

Fotografia $n^{\circ} 7$ Trincheira TRA4(Castro-Junior,1999) 


\section{Figura n 13 - Configuração esquemática da trincheira TRA4}

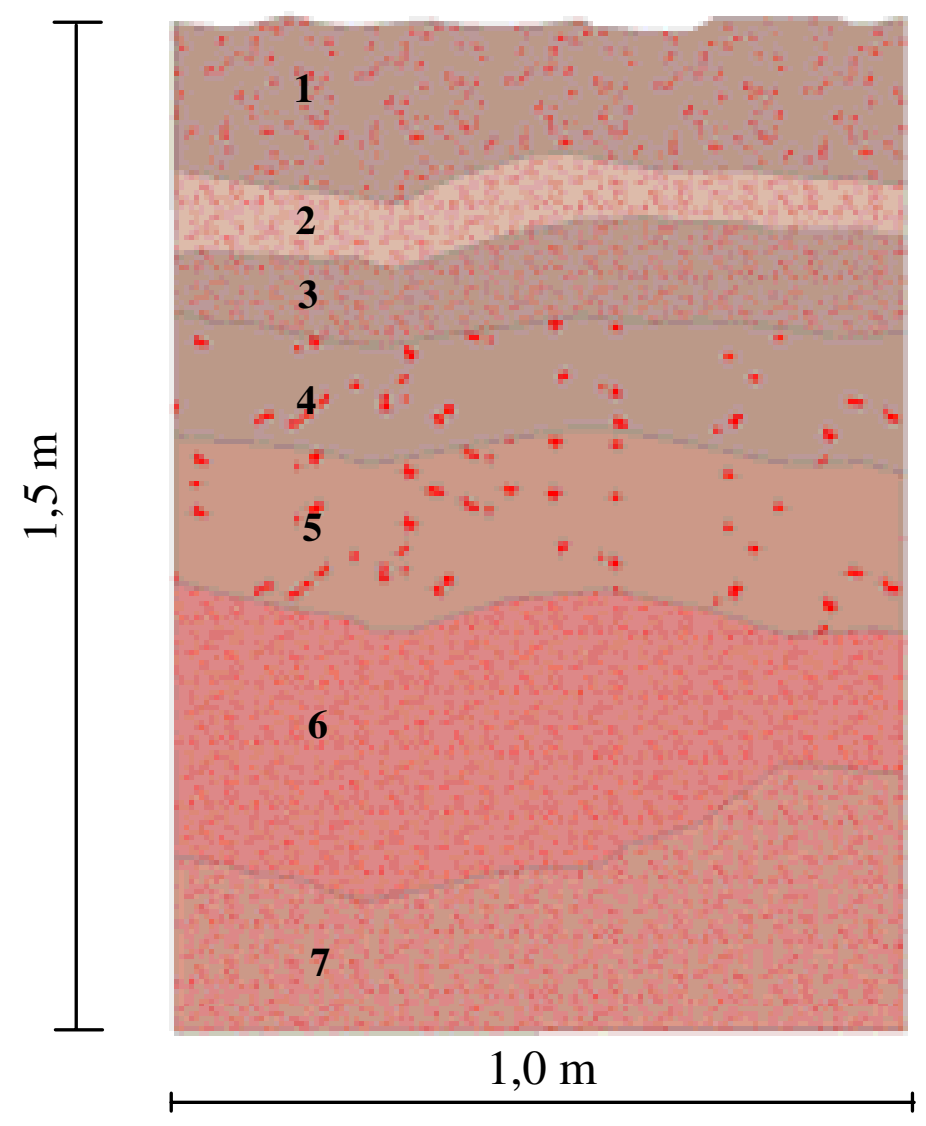

1. Cor bruna pálida (10YR 6/3), textura argilosa, estrutura em blocos angulares médios, presença de poucos poros médios, consistência seca dura , úmida muito firme, e quando molhado apresenta consistência não plástica e ligeiramente pegajosa, nódulos poucos, pequenos, duros, arredondados a angulares, vermelhos.

2. Cor bruna muito pálida (10YR 7/3), textura argilosa, estrutura em blocos angulares médios, presença de poros comuns tamanho médio, consistência seca dura, úmida friável, e molhada é ligeiramente plástica e ligeiramente pegajosa, nódulos freqüentes, pequenos, duros, arredondados, vermelhos.

3. Cor bruna pálida (10YR 6/3), textura argilosa, estrutura em blocos angulares médios, presença de poucos poros médios, consistência seca macia, úmida muito friável, ligeiramente plástico e ligeiramente pegajoso, nódulos freqüentes, pequenos, duros, esféricos, vermelhos.

4. Cor bruna pálida (10YR 6/3), textura argilosa, estrutura blocos angulares médios, presença de poucos poros médios, consistência seca solta, úmida é muito friável, e molhada é ligeiramente plástica e ligeiramente pegajosa, nódulos freqüentes, grandes, duros, irregulares, vermelhos.

5. Cor bruna clara amarelada (10YR 6/4) mosqueada, textura argilosa, poros comuns pequenos, consistência seca macia, úmida muito friável, e molhada é ligeiramente plástica e ligeiramente pegajosa, nódulos freqüentes, grandes, duros, vermelhos.

6. Cor amarela avermelhada (5YR 6/8), mosqueada, textura argilosa, estrutura granular, muitos poros pequenos, consistência seca macia, úmida muito friável, e molhada é ligeiramente plástica, ligeiramente pegajosa, nódulos muito freqüentes, pequenos, duros, irregulares, vermelhos.

7. Cor amarela avermelhada (5YR 6/6), textura argilosa, estrutura blocos angulares grandes, muitos poros pequenos, consistência seca macia, úmida muito friável, e molhada é plástica e pegajosa, nódulos muito freqüentes, pequenos, duros, irregulares, vermelhos. 
4. Horizonte de solo com $22 \mathrm{~cm}$ de espessura aproximadamente, iniciando entre 40-54 cm, cor bruno pálido (10YR 6/3 seca) e amarelo brunado (10YR 6/6 úmida), textura argilo-siltosa, estrutura blocos angulares médios, presença de poucos poros médios, consistência seca solta, úmida é muito friável, e molhada é ligeiramente plástica e ligeiramente pegajosa, nódulos freqüentes, grandes, duros, irregulares, vermelhos, óxido de ferro.

5. Horizonte de solo com $35 \mathrm{~cm}$ de espessura aproximadamente, iniciando entre 60-70 cm, cor bruna clara amarelada (10YR 6/4 seco) e amarela brunada (10YR 6/6 úmida) mosqueada, textura argilosa, presença de poros comuns pequenos, consistência seca macia, úmida é muito friável, e molhada é ligeiramente plástica e ligeiramente pegajosa, nódulos freqüentes de óxido de ferro, grandes, duros, vermelhos, transição gradual plana.

6. Horizonte de solo com $25 \mathrm{~cm}$ de espessura aproximadamente, iniciando entre 90-100 cm, cor amarelo avermelhado (5YR 6/8 seco), 5YR 5/8 (úmido), mosqueada, textura argilo-siltosa, estrutura granular, presença de muitos poros pequenos, consistência seca macia, úmida é muito friável, e molhado é ligeiramente plástico, ligeiramente pegajoso, nódulos de óxido de ferro muito freqüentes, pequenos, duros, irregulares, vermelhos, transição gradual plana.

7. Horizonte de solo iniciando entre 110-120 cm, cor amarelo avermelhado (5YR 6/6 seca e úmida), textura argilosa, estrutura blocos angulares grandes, presença de muitos poros pequenos, consistência seca macio, úmida é muito friável, e molhado é plástico e pegajoso, nódulos muito freqüentes, pequenos, duros, irregulares, vermelhos, óxido de ferro, transição não observável. 


\subsection{Topossequência $B$}

A topossequência B, localizada em uma vertente na margem esquerda da cabeceira do ribeirão Grande, instalada em uma colina ampla, com forma retilínea e muito longa, comprimento de rampa superior a 2400 metros, topo muito amplo e ligeiramente aplanado, com largura em torno de 1000 metros, amplitude de 16 metros. As declividades dessa vertente variam entre 0 - 5\% no terço superior, 0,5 - 1,5\% no terço médio e de 1,5 $0 \%$ no terço inferior, com ruptura de declive bem discreta, percebida na elaboração do perfil topográfico. A partir da ruptura de declive a declividade torna-se praticamente nula, configurando uma superfície aplanada até o fundo do vale, onde se observa pequeno aumento de declividadede.

Trata-se de uma colina que manteve-se nativa até outubro de 2000, quando então foi desmatada para a plantação de arroz, permanecendo intacto apenas o terço inferior, onde encontram-se os campos de murundus preservados.

A cobertura pedológica dominante na base da vertente é o PLINTOSSOLO ARGILÚVICO Distrófico, enquanto que na parte média e superior da vertente ocorre o LATOSSOLO BRUNO Distrófico câmbico e o Distroférrico plíntico, da mesma forma como na topossequência anterior. A figura 13 representa a topossequência $\mathrm{A}$, dando a indicação da disposição bidimensional dos seus principais horizontes.

1. Horizonte correspondendo ao ao solo do murundu, cor cinza muito escuro (10YR 3/1), textura argilo-arenosa, estrutura grumosa bem desenvolvida, consistência seca dura, úmida ligeiramente friável ou 
macia, molhado é plástico e pegajoso. Raízes comuns, bioporos milimétricos a centimétricos de formigas e cupins. Presença se pedotúbulos milimétricos a centimétricos, alguns com revestimentos amarelos. Porosidade de amontoamento dos agregados, bem como porosidade fissural, biológica e tubular fina.

2. Horizonte de solo que recobre toda a superfície da vertente, apresentando espessura máxima de $45 \mathrm{~cm}$ no terço superior da vertente, diminuindo para $20 \mathrm{~cm}$ no terço médio e para $8 \mathrm{~cm}$ no terço inferior, apresenta cor bruna, com tons que variam do acinzentado (10YR 4/2 e 10YR 3/2) ao amarelado (10YR 3/4) e ao escuro (10YR 3/3), nos $15 \mathrm{~cm}$ do topo do horizonte, textura argilosa a argilo-pouco arenosa, com presença de areia lavada, estrutura granular moderada média, às vezes grumosa, com grânulos pequenos de 1-2 mm, e grandes de 5-10 mm que se desfazem em microagregados, consistência seca macia, consistência úmida muito friável, e quando molhada, apresenta-se plástica a ligeiramente plástica e pegajosa. Apresenta volumes centimétricos de argila com consistência firme, poros muito pequenos são comuns a abundantes e poucos poros pequenos, presença dominante de raízes finas e poucas raízes de 2-5 $\mathrm{mm}$. Abaixo dos $15 \mathrm{~cm}$ iniciais, verifica-se neste horizonte a transição difusa para um outro nível de cor bruna com tons escuro (7,5YR 4/4 e 10YR 3/3), cinza muito escura (10YR 3/1) que vão clareando para bruna escura amarelada (10YR 4/4 e 10YR 4/6) e bruna acinzentada (10YR 5/2), textura argilosa, com ausência de areia lavada, estrutura grumosa pequena e granular moderada média, consistência seca solta a macia, consistência úmida muito friável, e molhada, a amostra de solo apresenta comportamento ligeiramente plástico a plástico e pegajoso, presença comum de nódulos de argila, poros muito pequenos são comuns a abundantes, e poucos a muitos poros pequenos. Presença de raízes finas de até 1-2 mm variando de raras a abundantes, transição gradual a clara, geralmente 
ondulada. Verifica-se a presença de cupins nos poros pequenos a médios na parte mais delgada deste horizonte, no final do terço inferior da vertente, onde os murundus não foram destruídos pelo uso do solo.

3. Horizonte de solo com espessuras que variam de $1,30 \mathrm{~m}$ no terço superior da vertente, a $0,30 \mathrm{~m}$ no terço médio, desaparecendo no final do terço inferior. Apresenta cores bruna forte (7,5YR 4/4, 4/6 e 5/8), bruna escura amarelada (10YR 4/6) e bruna amarelada (10YR 5/8 e 5/6), principal elemento de distinção com o horizonte sobrejacente, textura argilosa, com a presença comum de nódulos centimétricos de argila, em alguns níveis mais profundos verifica-se a textura argilo pouco arenosa, conferida por alguns grânulos milimétricos de plintita endurecida, conferindo à cor bruna uma tonalidade mais forte, mais avermelhada. Estrutura granular fraca, grânulos médios a pequenos que se desfazem em microagregados, estrutura maciça em alguns níveis. Consistência seca macia, consistência úmida solta a muito friável, e molhada a consistência é plástica a ligeiramente plástica e ligeiramente a pouco pegajosa, sendo às vezes, simplesmente pegajosa. Presença comum a abundante de poros muito pequenos e poucos a raros poros pequenos, no interior dos quais raras plintitas se desenvolvem, podendo-se observar a presença de poucas raízes finas e raras de até $2 \mathrm{~mm}$. Transição difusa a gradual plana.

4. Horizonte de solo que se desenvolve ao longo de toda a vertente, com espessuras que variam entre 10-70 $\mathrm{cm}$, alcançando a espessura máxima de 1,00 m no terço superior. Apresenta cor bruna (10YR 5/3) e bruna forte $(7,5 \mathrm{YR}$ 5/6) e (7,5YR 5/8) quando há maior concentração de concreções de óxido de ferro e nódulos de plintita. Distingue-se dos horizontes sobrejacentes devido a cor mais avermelhada, compacidade mais fofa e consistência mais pegajosa. Possui textura argilosa, estrutura granular fraca muito pequena a pequena, presença de poucas plintitas 
milimétricas dos 8 aos $18 \mathrm{~cm}$ de profundidade, que tornam-se abundantes, com cor vermelha (10R 4/8), dos 18 aos $60 \mathrm{~cm}$ de profundidade, a alcançam a mesma proporção da matriz a partir dos 60 $\mathrm{cm}$, e a cor vermelha da plintita torna-se levemente mais clara $(2,5 \mathrm{YR}$ 5/6), consistência úmida solta e molhada, a amostra de solo apresenta-se ligeiramente plástica e ligeiramente a pouco pegajosa, transição gradual plana. A característica unificadora deste horizonte é a presença de poucos volumes de plintita. No terço inferior apresenta-se com coloração bruna (10YR 5/3), passando mais abaixo para bruna pálida (10YR 6/3) e cinza claro brunado (10YR 6/2), portanto, a cor torna-se mais clara com o aumento da profundidade. Presença comum de poros muito pequenos, alguns com vestígios de raízes finas.

5. Horizonte de solo que se desenvolve nos terços inferior e médio da vertente, alcançando a espessura máxima de 1,45 m. Distingue-se do horizonte sobrejacente (n. 3 ) pela grande quantidade de plintita (50\%) em relação à matriz, conferindo coloração mais avermelhada e porosidade mais desenvolvida. A cor da matriz varia entre a bruna pálida (10YR 6/3), bruno amarelado (10YR 5/8), amarela brunada (10YR 6/6), bruna forte (7,5YR 5/8), amarelo avermelhado (7,5YR 6/8), vermelho (2,5YR 5/8), vermelho amarelado (5YR 5/8) e a cor da plintita que geralmente domina sobre a matriz é vermelha $(2,5 \mathrm{YR} 4 / 6,4 / 8$ e 5/8), manchas claras de cor bruna muito pálida (10YR 7/4) em matriz vermelha $(2,5 \mathrm{YR} 4 / 8)$ surgem nos níveis mais profundos deste horizonte, quando o nível freático é alcançado. Textura argilosa, estrutura granular fraca pequena $(1-2 \mathrm{~mm})$ a grande $(5-10 \mathrm{~mm})$, a matriz apresenta consistência úmida solta, enquanto a plintita possui consistência firme, quebrando-se com a pressão da ponta dos dedos, a consistência molhada é ligeiramente plástica e ligeiramente a pouco pegajosa. Presença de muitos poros muito pequenos e muitos poros pequenos, as raízes são raras e muito finas, transição gradual plana. 
5. Horizonte de solo que se estende do terço médio ao superior da encosta, ocupando as partes mais profundas, ou seja, a partir de $2 \mathrm{~m}$ de profundidade, com espessura e transição não observável. Apresenta predominantemente a cor vermelha (2,5 YR 4/6, 4/8 e 5/6), e secundariamente as cores vermelha amarelada (5YR 5/6 e 5/8 e 7,5 YR 6/6) e amarela avermelhada (7,5 YR 6/8), textura argilosa, consistência pegajosa, presença de nódulos de argila e concreções de óxido de ferro vermelhas (2,5 YR 4/8) e manchas claras de cor vermelha amarelada (7,5YR 6/6) a partir de 4,65 $\mathrm{m}$ de profundidade e bruna muito pálida (10YR 7/4) ao encontrar o nível freático.

6. Horizonte de solo que se desenvolve no terço inferior da vertente, a partir de 1,00 m de profundidade, cores variegadas, cinza (7,5YR 6/1), cinza claro (10YR 6/1) rosada (5YR 7/8) e vermelho (2,5YR 4/8), textura muito argilosa, consistência firme, deformável devido a umidade, consistência molhada muito plástica e muito pegajosa, transição não observável. 


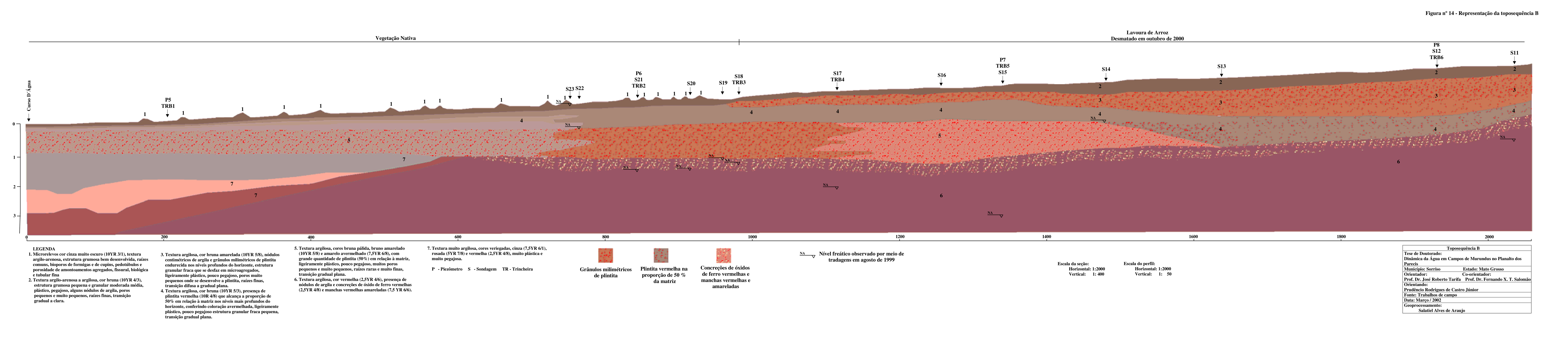




\subsubsection{Descrição das Trincheiras}

A representação da topossequência $A$ foi feita com base na descrição de 6 trincheiras, apresentadas neste capítulo, e 14 sondagens à trado ao longo da vertente, apresentadas no anexo II.

\subsubsection{Trincheira B1}

A trincheira B1 (TRB1), localizada no terço inferior da vertente, a aproximadamente 200 metros do início da vertente, onde o campo de murundus encontra-se preservado, sua configuração e descrição é apresentada na figura $\mathrm{n}^{\circ} 15$, seu aspecto geral pode ser observado na fotografia $n^{\circ} 8$, apresentando os seguintes horizontes:

1. Horizonte de solo de $8 \mathrm{~cm}$ de espessura, apresentando coloração bruna acinzentada muito escura (10YR 3/2), textura argilosa com presença de areia lavada, estrutura granular média, fraca coesão entre os agregados, com grânulos em torno de 2 a 5 mm envolvidos por uma matriz de areia lavada. O material seco apresenta consistência macia e quando molhado, a consistência é plástica e pegajosa, transição clara.

2. Horizonte de solo com $10 \mathrm{~cm}$ de espessura, iniciando aos $8 \mathrm{~cm} \mathrm{de}$ profundidade, coloração bruna (10YR 5/3), textura argilosa, sem a presença de areia lavada, estrutura granular muito pequena com grânulos de até $1 \mathrm{~mm}$. Quando úmido o solo apresenta-se com consistência muito friável, e molhado é plástico e pegajoso. Apresenta poros muito pequenos, em quantidade considerada poros comuns. Podese observar a presença de poucas plintitas milimétricas. A porosidade de raízes muito finas favorece a formação de plintita, transição gradual.

3. Horizonte de solo de $42 \mathrm{~cm}$, iniciando aos $18 \mathrm{~cm}$ de profundidade, cor bruna pálida (10YR 6/3), textura argilosa, estrutura granular muito pequena, com grânulos de até $1 \mathrm{~mm}$. Quando úmido o material 
apresenta consistência muito friável, e molhado o material é plástico e ligeiramente pegajoso. Apresenta poros muito pequenos em quantidade considerada como poros comuns, com presença comum de plintita de tamanho milimétrico a centimétrico. Destaca-se nesse horizonte a presença abundante de plintita com coloração vermelha (10YR 4/8), que tende a forma arredondada, observando-se no seu interior vestígio da matriz bruna pálida, transição clara.

4. Horizonte de solo de $33 \mathrm{~cm}$, iniciando aos $60 \mathrm{~cm}$ de profundidade, apresentando coloração cinza claro brunado (10YR 6/2), textura argilosa, estrutura granular muito pequena, com grânulos de até $1 \mathrm{~mm}$, com moderada coesão dentro e fora dos agregados. Consistência úmida firme, consistência molhada plástica e pegajosa, presença comum de poros muito pequenos. Este horizonte destaca-se pela grande quantidade de plintita de cor vermelha $(2,5 \mathrm{YR} 5 / 6)$ que apresenta-se em igual proporção à matriz, e mais clara que na camada sobrejacente, poros pequenos na matriz, bem como na plintita, porém com maior proporção na matriz, parte dos poros mostra vestígios de raiz fina, transição não observável.

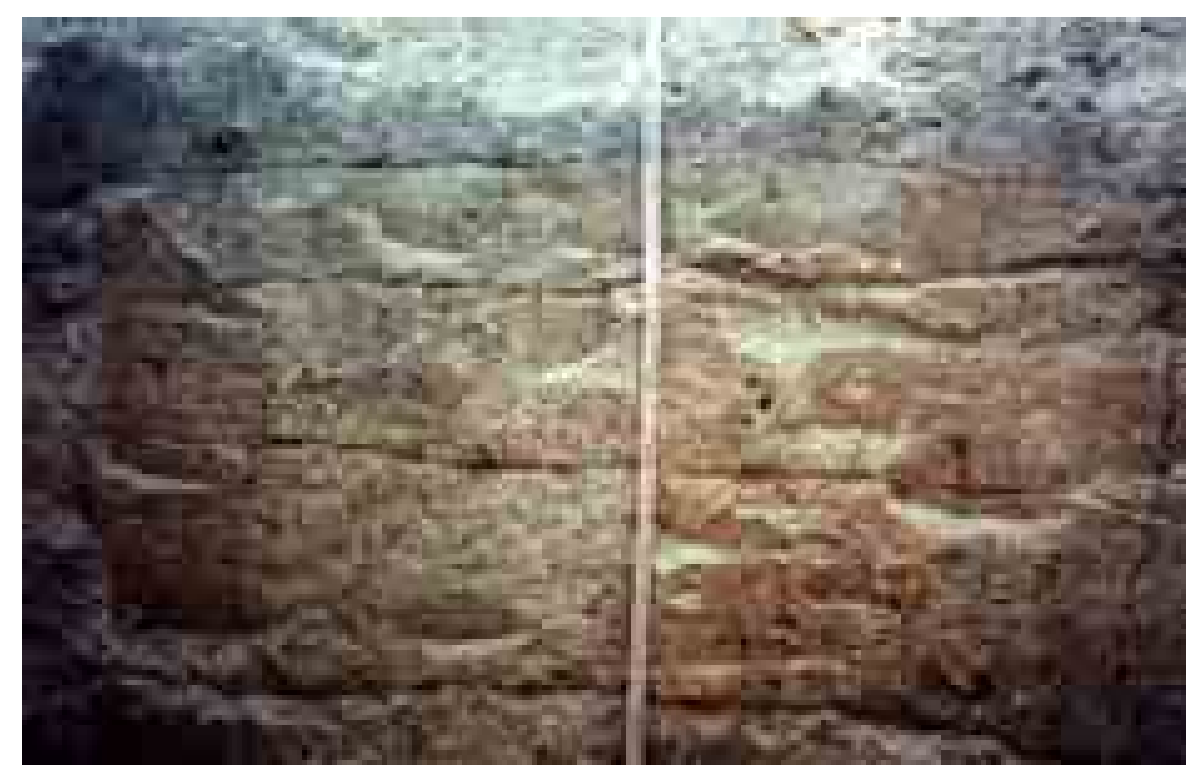

Fotografia $n^{\circ} 8$ Trincheira TRB1(Castro-Junior-2001) 


\section{Figura ${ }^{\circ} 15$ - Configuração esquemática da trincheira TRB1}

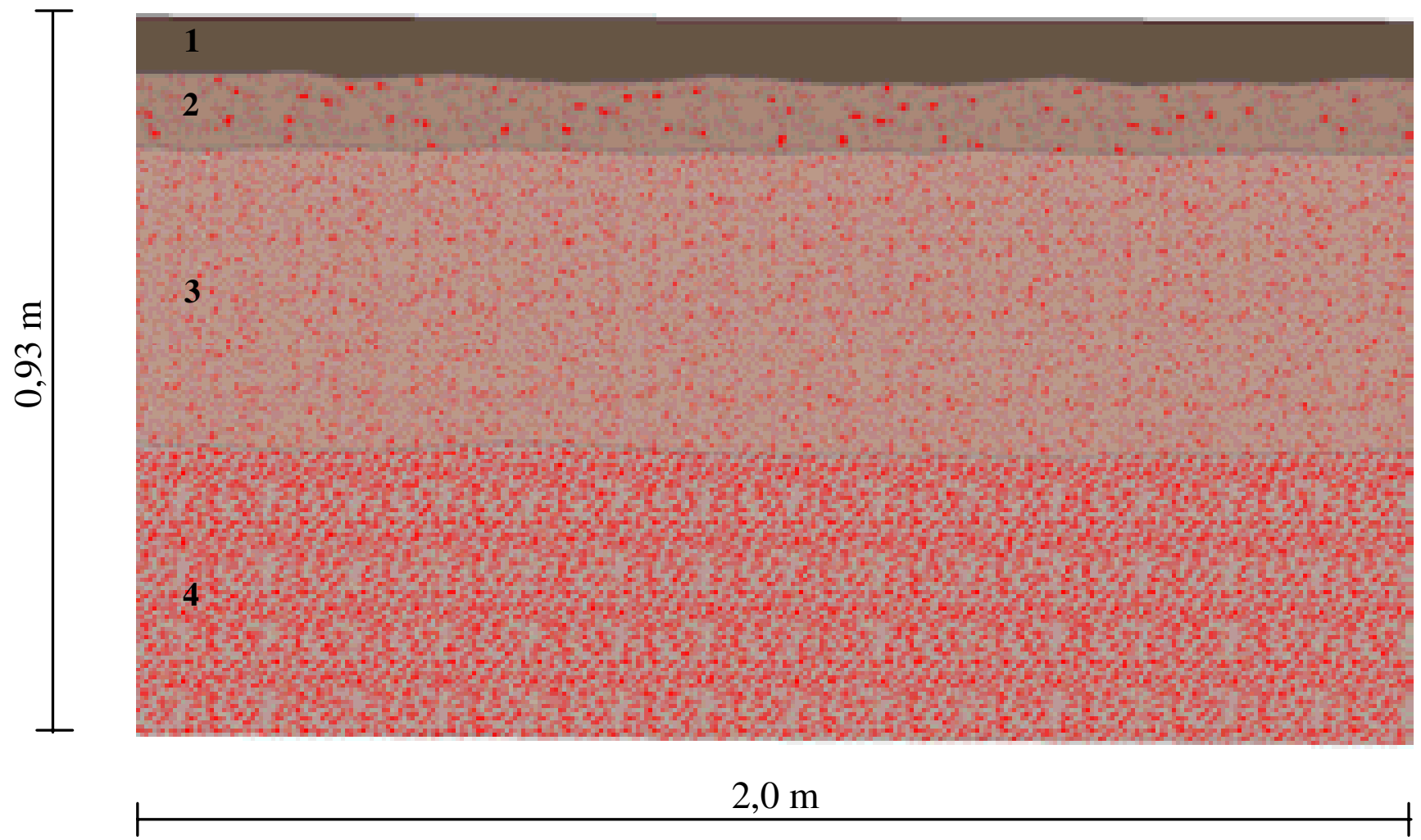

1. Cor bruna acinzentada muito escura (10YR 3/2), textura argilosa com areia lavada, estrutura granular média, com grânulos em torno de 2 a $5 \mathrm{~mm}$ envolvidos por uma matriz de areia lavada, consistência seca macia e molhado é plástico e pegajoso.

2. Cor bruna (10YR 5/3), textura argilosa, estrutura granular muito pequena com grânulos de até $1 \mathrm{~mm}$, consistência úmida muito friável, e molhada é plástica e pegajosa, poros muito pequenos comuns, poucas plintitas milimétricas.

3. Cor bruna pálida (10YR 6/3), textura argilosa, estrutura granular muito pequena, com grânulos de até $1 \mathrm{~mm}$, consistência úmida muito friável, e molhada é plástica e ligeiramente pegajosa, poros muito pequenos comuns, presença comum e abundante de plintita de cor vermelha (10YR 4/8), milimétrica a centimétrica.

4. Cor cinza claro brunado (10YR 6/2), textura argilosa, estrutura granular muito pequena, com grânulos de até $1 \mathrm{~mm}$, consistência úmida firme, e molhada é plástica e pegajosa, presença comum de poros muito pequenos, grande quantidade de plintita de cor vermelha (2,5YR 5/6), poros pequenos na matriz e na plintita, poros com vestígios de raiz fina. 


\subsubsection{Trincheira B2:}

A trincheira B2 (TRB2), localizada no terço inferior da vertente, a aproximadamente 858 metros do início da vertente, onde o campo de murundus encontra-se preservado, sua configuração e descrição é apresentada na figura $\mathrm{n}^{\circ} 16$, seu aspecto geral pode ser observado na fotografia $n^{\circ} 9$, apresentando os seguintes horizontes:

1. Horizonte de solo de $12 \mathrm{~cm}$, coloração cinza muito escuro (10YR 3/1), textura argilosa, ausência de areia lavada, estrutura granular fraca, tamanho entre 1 a $2 \mathrm{~mm}$, quando seca apresenta consistência macia, e molhada a consistência é plástica e pegajosa, presença de muitos poros muito pequenos e presença comum de poros pequenos, são abundantes as raízes muito finas, com diâmetro menor que $1 \mathrm{~mm}$, algumas raízes tem diâmetro superior a $1 \mathrm{~mm}$, transição gradual.

2. Horizonte de solo de $11 \mathrm{~cm}$, iniciando aos $12 \mathrm{~cm}$ de profundidade, cor bruna escura (10YR 3/3), textura argilosa, com ausência total de areia lavada, estrutura granular moderada, de tamanho pequeno, de 1 a $2 \mathrm{~mm}$, quando úmido o material é muito friável, e molhado é ligeiramente pegajoso. Presença de muitos poros muito pequenos, pequenos e médios, verifica-se a presença de cupins nos poros pequenos e médios. Presença de muitas raízes finas, transição clara.

3. Camada de $48 \mathrm{~cm}$ de solo, iniciando aos $23 \mathrm{~cm}$ de profundidade, cor bruna (10YR 5/3), textura argilosa, raras plintitas milimétricas, perceptíveis apenas quando a amostra é destruída molhada na palma da mão com a faca, estrutura granular média fraca, com grânulos em torno de $0,5 \mathrm{~cm}$. Consistência úmida muito friável e quando molhado o material apresenta-se plástico e pegajoso. Presença de muito poros muito pequenos e poucos poros pequenos, muitas raízes finas e médias, em torno de $0,2 \mathrm{~mm}$, transição clara. 


\subsubsection{Trincheira B2:}

A trincheira B2 (TRB2), localizada no terço inferior da vertente, a aproximadamente 858 metros do início da vertente, onde o campo de murundus encontra-se preservado, sua configuração e descrição é apresentada na figura $n^{\circ} 16$, seu aspecto geral pode ser observado na fotografia $n^{\circ} 9$, apresentando os seguintes horizontes:

1. Horizonte de solo de $12 \mathrm{~cm}$, coloração cinza muito escuro (10YR 3/1), textura argilosa, ausência de areia lavada, estrutura granular fraca, tamanho entre 1 a $2 \mathrm{~mm}$, quando seca apresenta consistência macia, e molhada a consistência é plástica e pegajosa, presença de muitos poros muito pequenos e presença comum de poros pequenos, são abundantes as raízes muito finas, com diâmetro menor que $1 \mathrm{~mm}$, algumas raízes tem diâmetro superior a 1 mm, transição gradual.

2. Horizonte de solo de $11 \mathrm{~cm}$, iniciando aos $12 \mathrm{~cm}$ de profundidade, cor bruna escura (10YR 3/3), textura argilosa, com ausência total de areia lavada, estrutura granular moderada, de tamanho pequeno, de 1 a $2 \mathrm{~mm}$, quando úmido o material é muito friável, e molhado é ligeiramente pegajoso. Presença de muitos poros muito pequenos, pequenos e médios, verifica-se a presença de cupins nos poros pequenos e médios. Presença de muitas raízes finas, transição clara.

3. Camada de $48 \mathrm{~cm}$ de solo, iniciando aos $23 \mathrm{~cm}$ de profundidade, cor bruna (10YR 5/3), textura argilosa, raras plintitas milimétricas, perceptíveis apenas quando a amostra é destruída molhada na palma da mão com a faca, estrutura granular média fraca, com grânulos em torno de $0,5 \mathrm{~cm}$. Consistência úmida muito friável e quando molhado o material apresenta-se plástico e pegajoso. Presença de muito poros muito pequenos e poucos poros pequenos, muitas raízes finas e médias, em torno de $0,2 \mathrm{~mm}$, transição clara. 


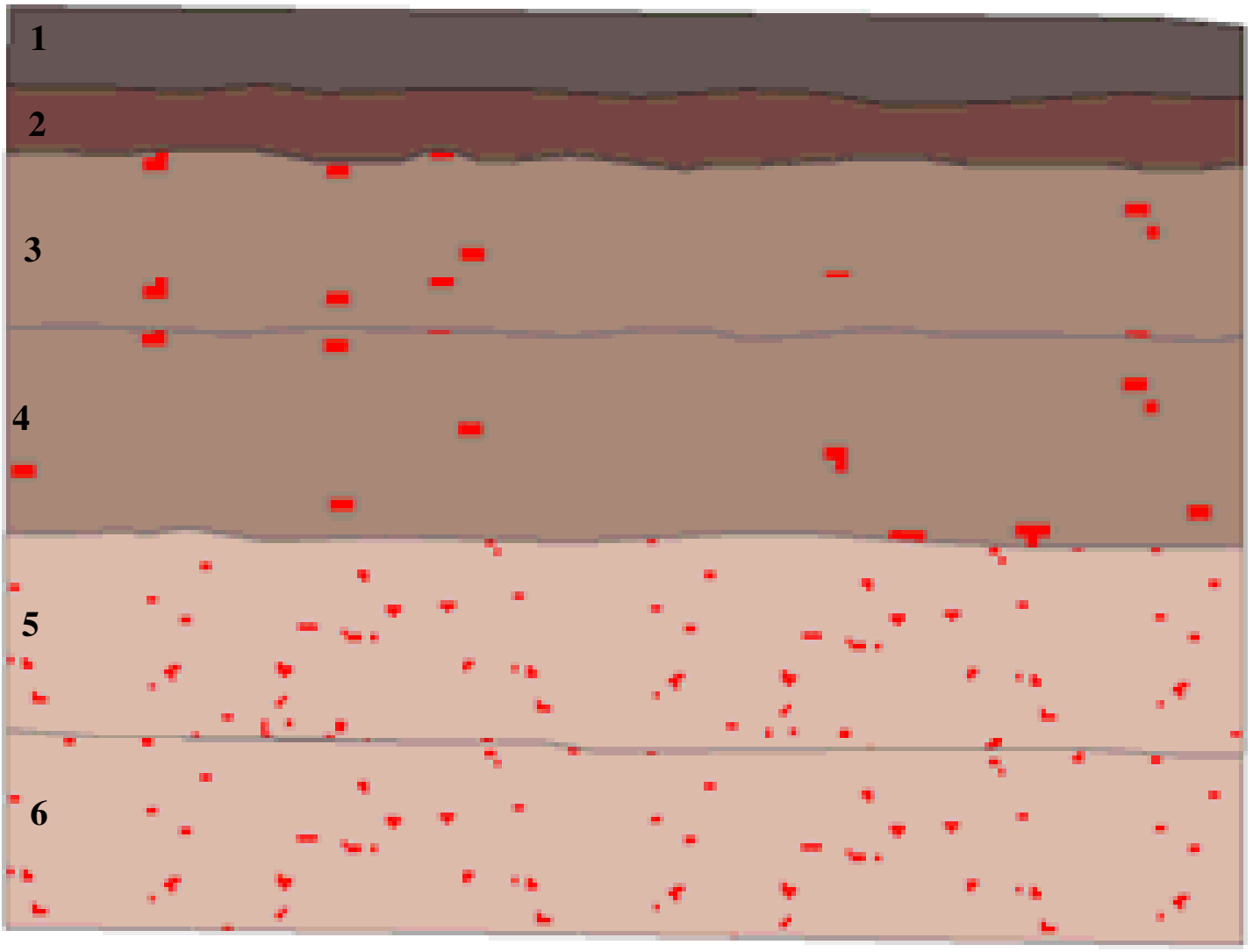

1. Cor cinza muito escuro (10YR 3/1), textura argilosa, estrutura granular fraca, tamanho entre 1 a $2 \mathrm{~mm}$, consistência seca macia, e molhada é plástica e pegajosa, presença de muitos poros muito pequenos e presença comum de poros pequenos, raízes muito finas abundantes.

2. Cor bruna escura (10YR 3/3), textura argilosa, estrutura granular moderada, de tamanho pequeno, de 1 a $2 \mathrm{~mm}$, consistência úmida muito friável, e molhada é ligeiramente pegajosa, muitos poros muito pequenos, pequenos e médios, presença de cupins nos poros pequenos e médios, muitas raízes finas.

3. Cor bruna (10YR 5/3), textura argilosa, raras plintitas milimétricas, perceptíveis quando a amostra é destruída molhada na palma da mão com a faca, estrutura granular média fraca, com grânulos em torno de $0,5 \mathrm{~cm}$, consistência úmida muito friável e molhada é plástica e pegajosa, muitos poros muito pequenos e poucos poros pequenos, muitas raízes finas e médias.

4. Cor bruna clara amartelada, textura argilosa, estrutura granular moderada média, consistência úmida muito friável e molhada é plástica e pegajosa, poucas raízes, dominando as finas, raras plintitas.

5. Cor bruna muito pálida (10YR 7/3), textura argilosa, presença comum de plintita de cor bruna avermelhada (2.5YR 4/4), estrutura granular média fraca, grânulos de $0,5 \mathrm{~cm}$, consistência úmida muito friável, e molhada é ligeiramente plástica e pegajosa.

6. Cor bruna muito pálida (10YR 7/3), textura argilosa, presença comum de plintita de cor bruna avermelhada (2,5YR 4/4), estrutura granular média fraca, com grânulos de $0,5 \mathrm{~cm}$, consistência úmida muito friável, e molhada é ligeiramente plástica e pegajosa. 
4. Horizonte de solo de $34 \mathrm{~cm}$, iniciando aos $51 \mathrm{~cm}$ de profundidade, cor bruna clara amarelada, textura argilosa, estrutura granular moderada média, consistência úmida muito friável e molhada apresenta comportamento plástico e pegajoso. Poucas raízes, dominando as finas, observando-se apenas uma de $2 \mathrm{~mm}$ de diâmetro, raras plintitas, transição clara.

5. Horizonte de solo com $34 \mathrm{~cm}$, iniciando aos $85 \mathrm{~cm}$ de profundidade, cor bruna muito pálida (10YR 7/3), textura argilosa com a presença comum de plintita de cor bruna avermelhada (2.5YR 4/4), observadas tanto na parede da trincheira como na mão, estrutura granular média fraca, grânulos de $0,5 \mathrm{~cm}$, consistência úmida muito friável, e molhada apresenta-se ligeiramente plástica e pegajosa, transição difusa.

6. Horizonte de solo de $31 \mathrm{~cm}$, iniciando aos 1,19 $\mathrm{cm}$ de profundidade, de coloração bruna muito pálida (10YR 7/3), textura argilosa, com presença comum de plintita de cor bruna avermelhada (2,5YR 4/4), em quantidade maior e mais endurecida que na camada sobrejacente, estrutura granular média fraca, com grânulos de $0,5 \mathrm{~cm}$, quando úmida apresenta-se muito friável, e molhada, ligeiramente plástica e pegajosa, transição não observável.

\subsubsection{Trincheira B3:}

A trincheira B3 (TRB3), localizada no terço inferior da vertente, a aproximadamente 1.000 metros do início da vertente, onde o campo de murundus foi desmatado em outubro de 2000 para dar lugar a lavoura de arroz, sua configuração e descrição é apresentada na figura $n^{\circ} 17$, seu aspecto geral pode ser observado na fotografia $\mathrm{n}^{\circ} 10$, apresentando os seguintes horizontes: 
1. Horizonte de solo de $12 \mathrm{~cm}$ de espessura, cor bruna muito escura acinzentada (10YR 3/2), textura argilo-pouco arenosa (areia fina), estrutura granular grumosa, moderada, grânulos grandes, consistência da amostra seca é macia, molhada é ligeiramente plástica e pegajosa. Presença de muitos poros muito pequenos e presença comum de poros pequenos, muitas raízes com diâmetro menor que $1 \mathrm{~mm}$, predominando raízes com diâmetro de $2 \mathrm{~mm}$, transição clara ondulada.

2. Horizonte de solo de $18 \mathrm{~cm}$ de espessura, cor bruna amarelada (10YR $5 / 8)$, textura argilosa, estrutura granular fraca, grânulos médios (2-5 $\mathrm{mm}$ ), consistência úmida muito friável e quando molhado apresenta comportamento ligeiramente plástico e pegajoso. Porosidade muito pequena, muitos poros muito pequenos, poros preenchidos por material de mesma cor, porém com tonalidade mais vermelha. Poucas raízes finas, algumas mais grossas, transição clara.

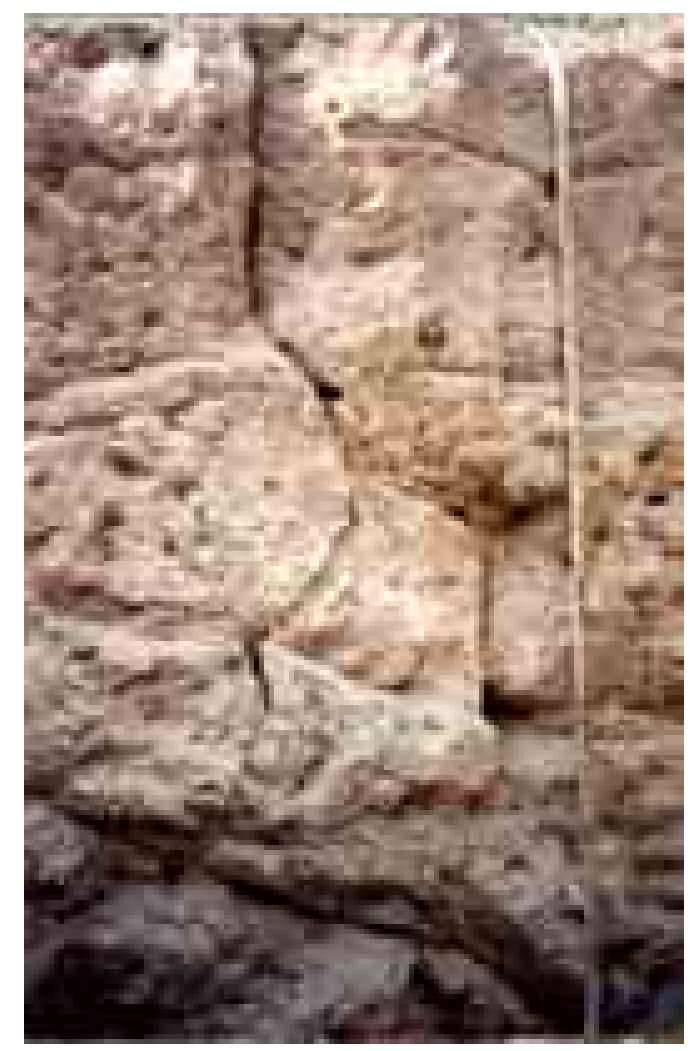

Fotografia $n^{\circ} 10$ Trincheira TRB3(Castro-Junior-2001) 


\section{Figura n 17 - Configuração esquemática da trincheira TRB3}

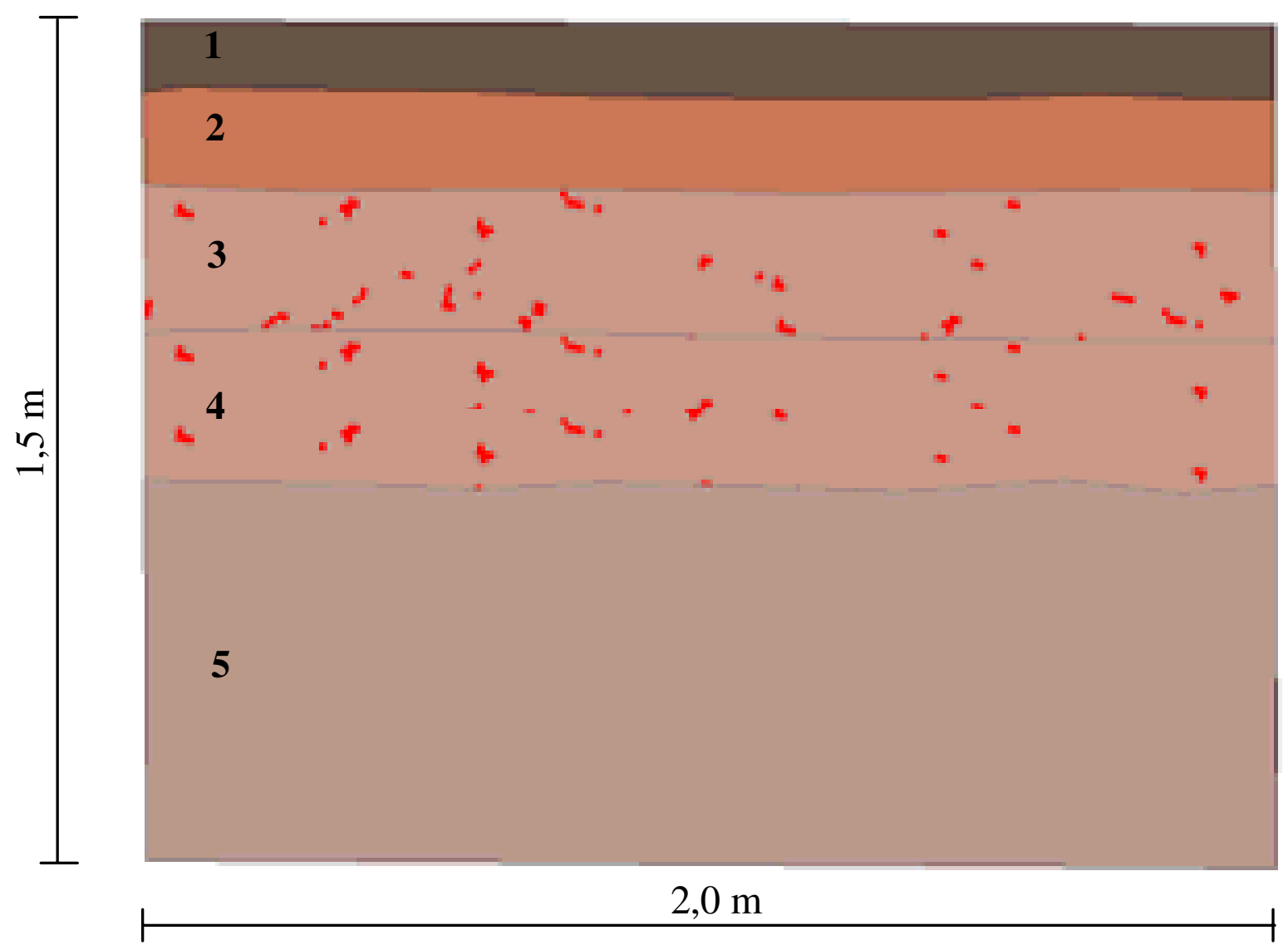

1. Cor bruna muito escura acinzentada (10YR 3/2), textura argilosa com pouca areia fina, estrutura granular grumosa, moderada, grânulos grandes, consistência seca macia, e molhada é ligeiramente plástica e pegajosa, presença de muitos poros muito pequenos e presença comum de poros pequenos, muitas raízes finas, predominando raízes com diâmetro de $2 \mathrm{~mm}$.

2. Cor bruna amarelada (10YR 5/8), textura argilosa, estrutura granular fraca, grânulos médios $(2-5 \mathrm{~mm})$, consistência úmida muito friável e molhada é ligeiramente plástica e pegajosa, porosidade muito pequena, muitos poros muito pequenos, poucas raízes finas, algumas mais grossas.

3. Cor bruna clara amarelada (10YR 6/4), com presença comum de plintita de cor vermelha (2,5YR 4/8), textura argilosa, estrutura granular fraca, grânulos médios (2-5 mm), consistência úmida muito friável e molhada é plástica e pegajosa, presença de muitos poros pequenos, poucas raízes finas.

4. Cor bruna clara amarelada (10YR 6/4), textura argilosa, estrutura granular muito fraca, grânulos médios (2-5 mm), consistência úmida solta, e molhada é plástica e pegajosa, volumes comuns de plintita de consistência firme, muitos poros muito pequenos, poucas raízes finas.

5. Cores variando entre bruno pálido (10YR 6/3) da matriz e o vermelho $(2,5 \mathrm{YR}$ 4/8 da plintita, textura argilosa, estrutura granular fraca e grande (5 a $10 \mathrm{~mm})$, consistência úmida da matriz é solta e da plintita é firme, molhada é ligeiramente plástica e pouco pegajosa, raízes raras e muito finas. 
3. Horizonte de solo de $25 \mathrm{~cm}$ de espessura, iniciando aos $30 \mathrm{~cm}$ de profundidade, cor bruna clara amarelada (10YR 6/4), com presença comum de plintita de cor vermelha $(2,5 \mathrm{YR} 4 / 8)$, que se destaca em relação à camada sobrejacente, em que as plintitas eram raras. Textura argilosa, estrutura granular fraca, grânulos médios (2-5 $\mathrm{mm})$, consistência úmida muito friável e quando molhado apresenta consistência plástica e pegajosa. Presença de muitos poros pequenos, poucas raízes finas, transição clara.

4. Horizonte de solo de $27 \mathrm{~cm}$ de espessura, iniciando aos $55 \mathrm{~cm}$ de profundidade, cor bruna clara amarelada (10YR 6/4), textura argilosa, estrutura granular muito fraca, grânulos médios $(2-5 \mathrm{~mm})$, consistência úmida solta, e quando molhado é plástico e pegajoso, volumes comuns de plintita de consistência firme, muitos poros muito pequenos, poucas raízes finas. Distingue-se da camada sobrejacente pela consistência mais fofa, maior porosidade e poros mais visíveis, transição difusa.

5. Horizonte de solo de $69 \mathrm{~cm}$, iniciando aos $82 \mathrm{~cm}$ de profundidade, cores variando entre a bruna pálida (10YR 6/3) da matriz e a vermelha (2,5 YR 4/8) da plintita, textura argilosa, estrutura granular fraca e grande (5 a $10 \mathrm{~mm}$ ), quando úmido a consistência da matriz é solta e da plintita é firme, molhado apresenta-se ligeiramente plástico e pouco pegajoso, raízes raras e muito finas. Facilmente distinguível da camada anterior devido a plintita que domina em relação a matriz, transição não observável.

\subsubsection{Trincheira B4:}

A trincheira B4 (TRB4), localizada no terço médio da vertente, a aproximadamente 1.130 metros do início da vertente, onde o campo de murundus foi desmatado para abrir espaço para lavoura de arroz, sua 
configuração e descrição é apresentada na figura $n^{\circ} 18$, seu aspecto geral pode ser observado na fotografia $n^{\circ} 11$, apresentando os seguintes horizontes:

1. Horizonte de solo de $14 \mathrm{~cm}$ de espessura, cor bruna escura (10YR 3/3), textura argilosa, estrutura granular grumosa pequena, quando seca a consistência é solta, e molhada, a consistência é plástica e pegajosa. Presença de muitas raízes finas, em torno de $2 \mathrm{~mm}$, transição clara ondulada.

2. Horizonte de solo com $28 \mathrm{~cm}$, cor bruna amarelada (10YR 5/6), textura granular fraca pequena, quando úmida possui consistência muito friável, e molhada, a consistência é ligeiramente plástica e pegajosa. Presença de muitos poros muito pequenos e poucos poros pequenos, com raras plintitas que se desenvolvem dentro dos poros e as poucas raízes presentes são finas, transição clara.

3. Horizonte de solo de $68 \mathrm{~cm}$, iniciando aos $42 \mathrm{~cm}$ de profundidade, cor bruna amarelada (10YR 5/8), textura argilo-pouco arenosa, conferida por alguns grânulos milimétricos de plintita endurecida, estrutura granular fraca pequena, quando úmida a amostra do solo é muito friável, e molhada é ligeiramente plástica e pegajosa, presença de muitos poros muito pequenos, alguns poros médios. Esta camada se diferencia da camada sobrejacente pela presença comum de plintita e pela coloração mais amarelada, transição clara.

4. Camada de solo de $40 \mathrm{~cm}$, iniciando aos $110 \mathrm{~cm}$ de profundidade, que se distingue da camada sobrejacente pela grande quantidade de plintita (50\%) em relação a matriz, conferindo coloração mais avermelhada e porosidade mais desenvolvida, apresentando muitos poros muito pequenos, pequenos e grandes, a cor é amarela brunada (10YR 6/6), textura argilosa granular fraca pequena, consistência úmida da matriz é 
dos dedos. Molhada, a amostra de solo apresenta comportamento ligeiramente plástico e ligeiramente pegajoso, raras raízes muito finas, transição não observável.

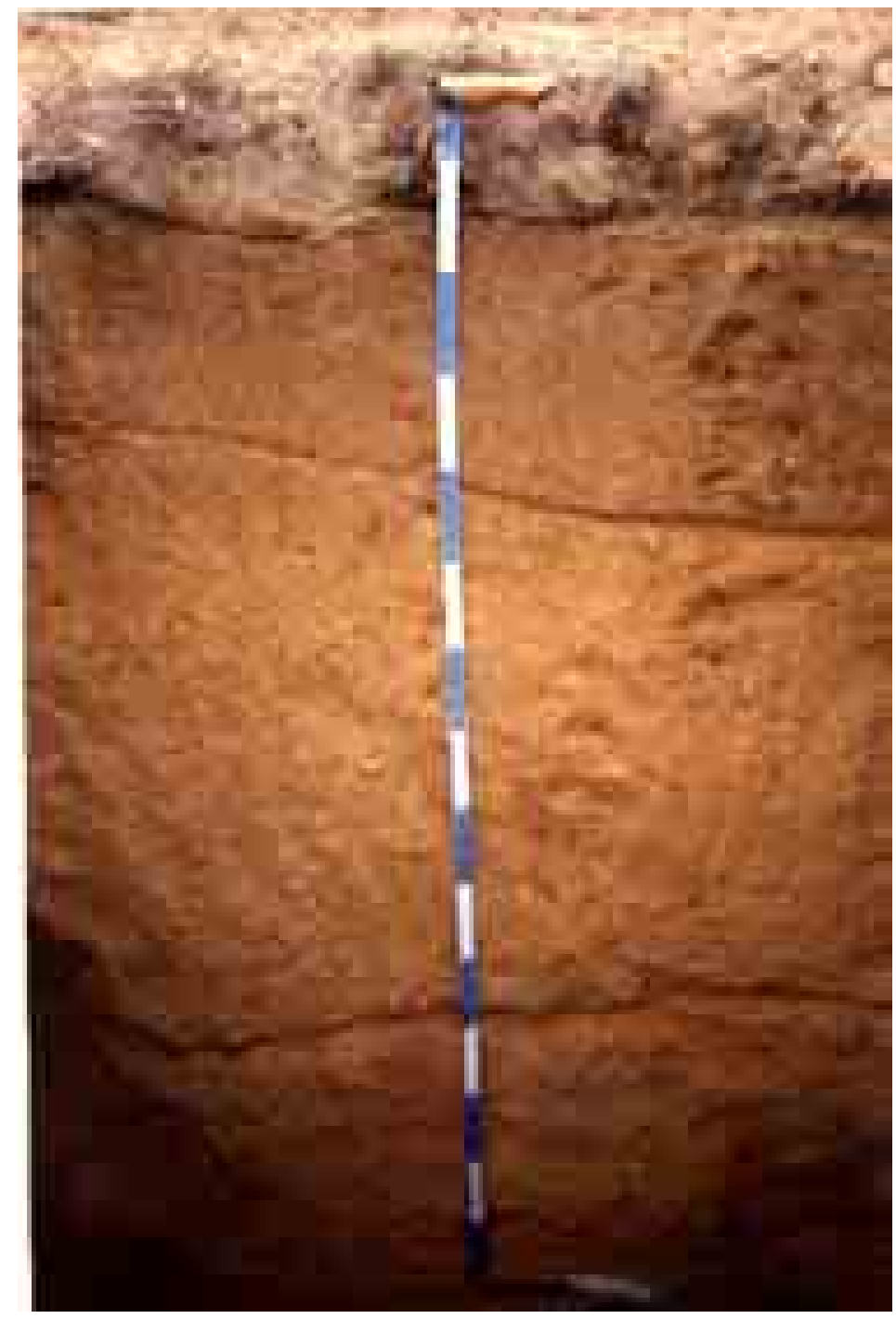

Fotografia $n^{\circ} 11$ Trincheira TRB4 
Figura no 18 - Configuração esquemática da trincheira TRB4

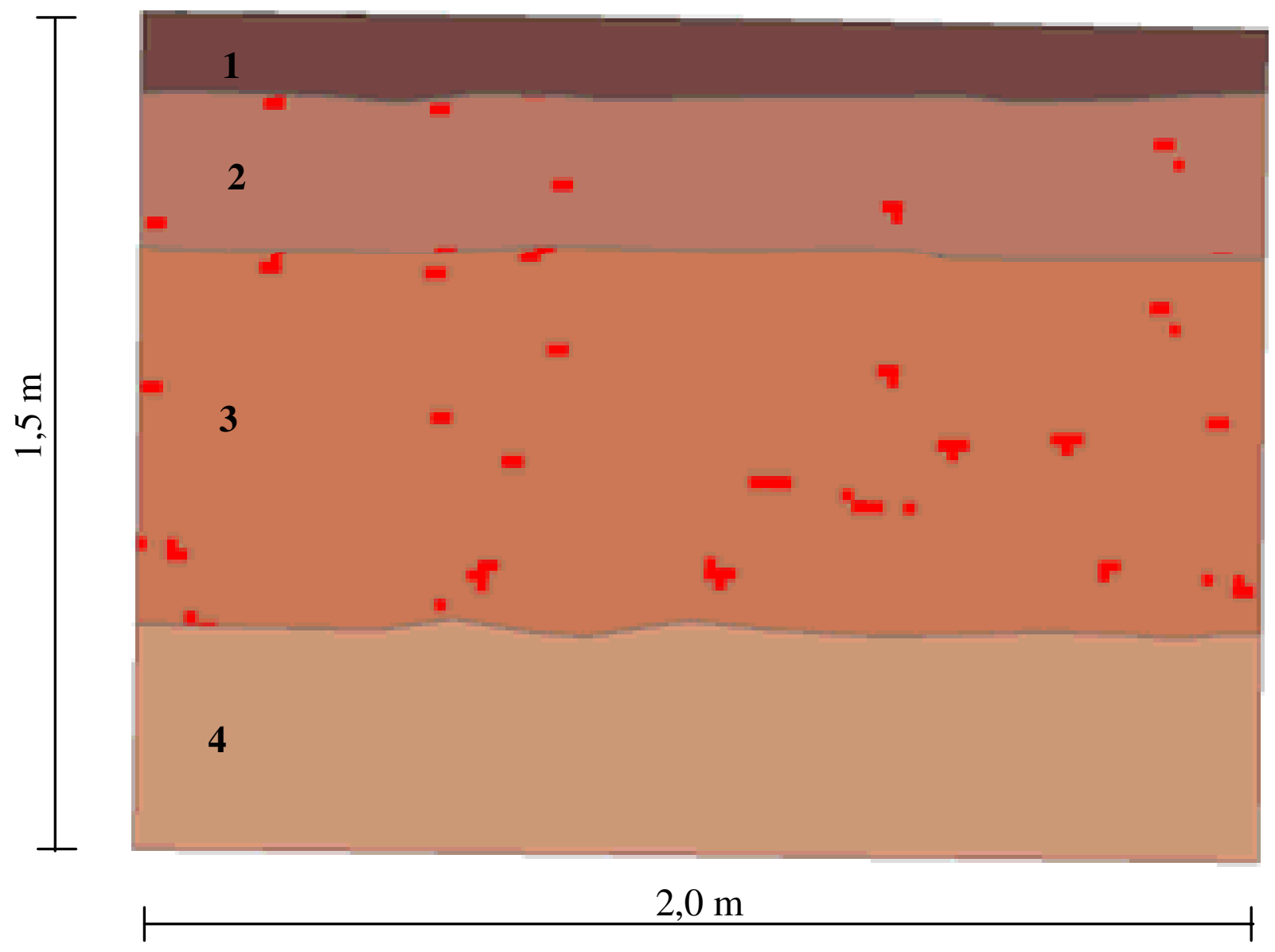

1. Cor bruna escura (10YR 3/3), textura argilosa, estrutura granular grumosa pequena, consistência seca solta, e molhada é plástica e pegajosa, presença de muitas raízes finas.

2. Cor bruna amarelada (10YR 5/6), textura granular fraca pequena, quando úmida consistência muito friável, e molhada é ligeiramente plástica e pegajosa, presença de muitos poros muito pequenos e poucos poros pequenos, raras plintitas que se desenvolvem dentro dos poros, poucas raízes finas.

3. Cor bruna amarelada (10YR 5/8), textura argilo-pouco arenosa, conferida por alguns grânulos milimétricos de plintita endurecida, estrutura granular fraca pequena, consistência úmida muito friável, e molhada é ligeiramente plástica e pegajosa, presença de muitos poros muito pequenos e de alguns poros médios.

4. Cor amarela brunada (10YR 6/6), textura argilosa granular fraca pequena, consistência úmida solta, e molhada é ligeiramente plástica e ligeiramente pegajososa, raras raízes muito finas. 


\subsubsection{Trincheira B5}

A trincheira B4 (TRB5), localizada no terço médio da vertente, a aproximadamente 1.384 metros do início da vertente, onde o campo de murundus foi desmatado para abrir espaço para lavoura de arroz, sua configuração e descrição é apresentada na figura $n^{\circ} 19$, seu aspecto geral pode ser observado na fotografia $\mathrm{n}^{\circ} 12$, apresentando os seguintes horizontes:

6. Horizonte de solo de $16 \mathrm{~cm}$, cor bruna escura amarelada (10YR 4/4), textura argilo-pouco arenosa, estrutura granular grumosa, grânulos pequenos 1-2 mm) que se desfazem em micro-agregados, consistência seca macia e quando molhado apresenta-se ligeiramente plástico e pegajoso. Raízes finas são comuns, poucas raízes de até $2 \mathrm{~mm}$, transição gradual ondulada.

7. Horizonte de solo de $27 \mathrm{~cm}$, distinguindo-se da camada sobrejacente pela cor mais escura e maior compacidade, cor bruna escura amarelada (10YR 4/6), textura argilosa, estrutura granular fraca pequena que se desfaz em micro-agregados, consistência seca macia, com presença de grânulos de argila milimétricos ligeiramente duros, consistência molhada ligeiramente plástica e pouco pegajosa. presença de muitos poros muito pequenos e raros poros pequenos, poucas raízes finas, transição gradual plana.

8. Horizonte de solo de $59 \mathrm{~cm}$, distinguindo-se do anterior pela cor mais avermelhada e compacidade mais fofa, iniciando aos $43 \mathrm{~cm}$ de profundidade, cor bruna amarelada (10YR 5/8), textura argilosa, estrutura granular fraca pequena que se desfaz em microagregados, consistência úmida solta com poucos grânulos de argila e volumes de plintita ligeiramente duros, quando molhada a amostra de solo 
apresenta-se ligeiramente plástica e pouco pegajosa. Presença de muitos poros muito pequenos, raras raízes finas, transição gradual plana.

9. Horizonte de solo de $58 \mathrm{~cm}$, iniciando aos $72 \mathrm{~cm}$ de profundidade, cor bruna forte (7,5YR 5/8), textura argilosa, apresentando poucos volumes de plintita ligeiramente duros, que se desfazem em microagregados, consistência úmida solta, e molhada a amostra de solo tem comportamento ligeiramente plástico e ligeiramente pegajoso, presença de muitos poros muito pequenos e muitos poros pequenos, raras raízes muito finas, transição gradual.

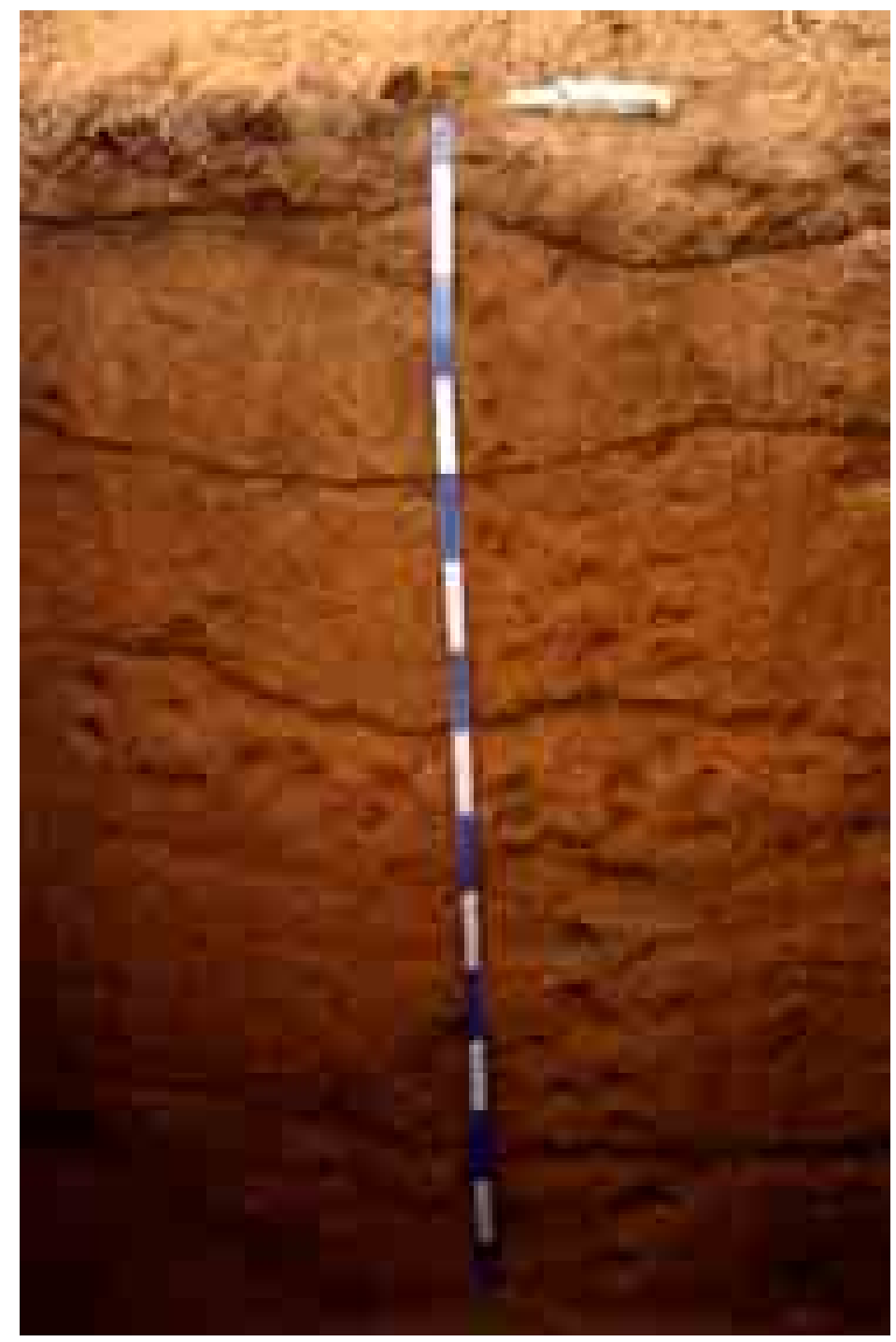

Fotografia $n^{\circ} 12$ Trincheira TRB5(Castro-Junior-2001) 


\section{Figura n ${ }^{\circ} 19$ - Configuração esquemática da trincheira TRB5}

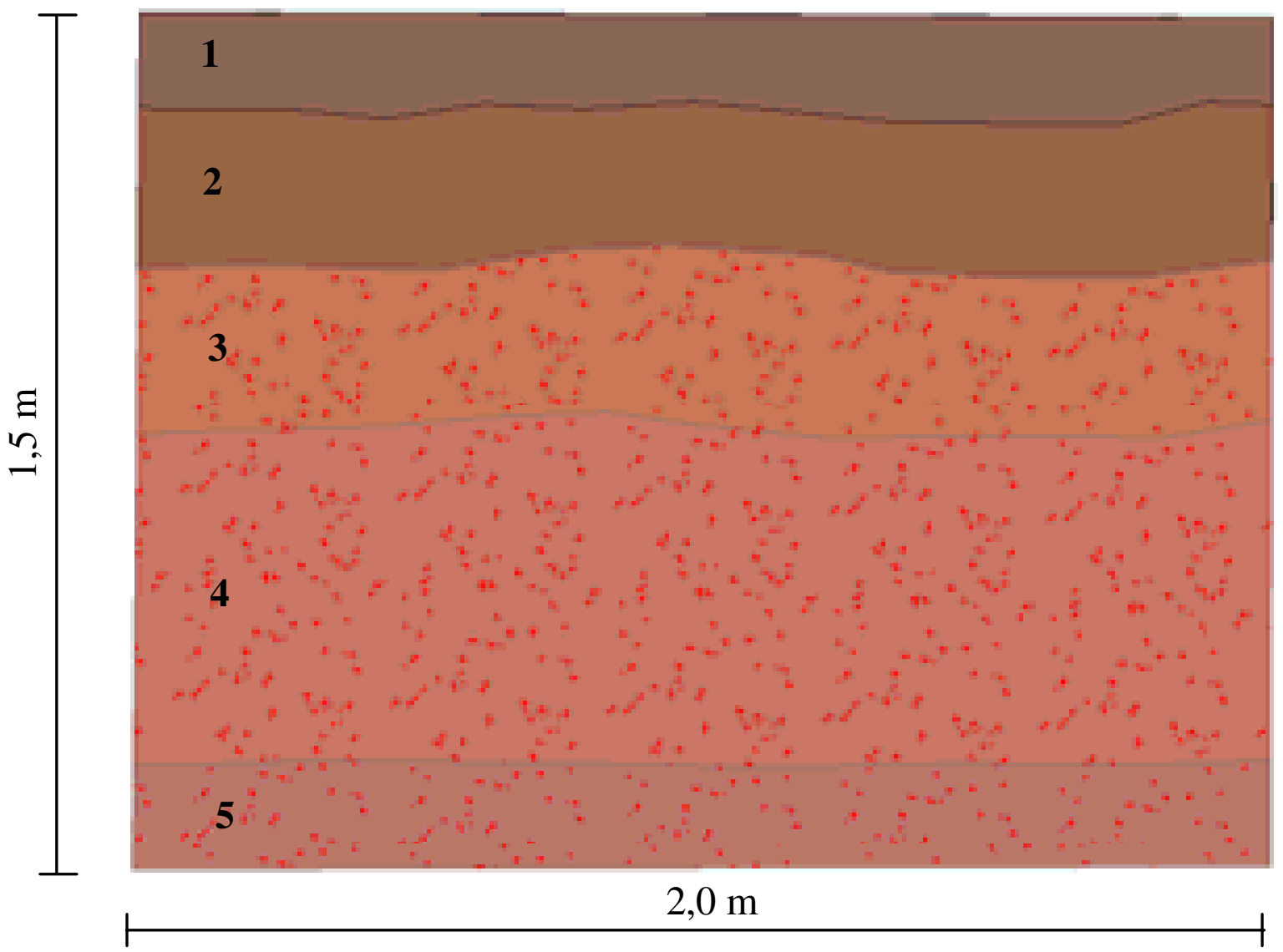

1. Cor bruna escura amarelada (10YR 4/4), textura argilo-pouco arenosa, estrutura granular grumosa, grânulos pequenos (1-2 mm) que se desfazem em microagregados, consistência seca macia e molhada é ligeiramente plástica e pegajos, raízes finas comuns, poucas raízes de até $2 \mathrm{~mm}$.

2. Cor bruna escura amarelada (10YR 4/6), textura argilosa, estrutura granular fraca pequena que se desfaz em micro-agregados, consistência seca macia, com presença de grânulos de argila milimétricos ligeiramente duros, consistência molhada ligeiramente plástica e pouco pegajosa. presença de muitos poros muito pequenos e raros poros pequenos, poucas raízes finas.

3. Cor bruna amarelada (10YR 5/8), textura argilosa, estrutura granular fraca pequena que se desfaz em microagregados, consistência úmida solta com poucos grânulos de argila e volumes de plintita ligeiramente duros, e molhada é ligeiramente plástica e pouco pegajosa, muitos poros muito pequenos, raras raízes finas.

4. Cor bruna forte (7,5YR 5/8), textura argilosa, poucos volumes de plintita ligeiramente duros, que se desfazem em microagregados, consistência úmida solta, e molhada é ligeiramente plástica e ligeiramente pegajosa, presença de muitos poros muito pequenos e muitos poros pequenos raras raízes muito.

5. Cor bruna forte $(7,5 \mathrm{YR} 5 / 6)$, textura argilosa com volumes de plintita ligeiramente dura, centimétricos e milimétricos, presença de muitos poros muito pequenos e muitos poros pequenos, poucas raízes muito finas. 
10. Horizonte de solo de $20 \mathrm{~cm}$, iniciando aos $130 \mathrm{~cm}$ de profundidade, que se distingue do anterior pela coloração mais avermelhada, maior quantidade de plintita ligeiramente dura e centimétrica, cor bruna forte (7,5YR 5/6), textura argilosa com volumes de plintita ligeiramente dura, centimétricos e milimétricos. Presença se muitos poros muito pequenos e muitos poros pequenos, poucas raízes muito finas, transição não observável.

\subsubsection{Trincheira B6:}

A trincheira B6 (TRB6), localizada no terço superior da vertente, a aproximadamente 1.1990 metros do início da vertente, nesse setor, o campo de murundus foi desmatado para abrir espaço para lavoura de arroz, sua configuração e descrição é apresentada na figura $n^{\circ} 20$, seu aspecto geral pode ser observado na fotografia $\mathrm{n}^{\circ} 13$, apresentando os seguintes horizontes:

1. Horizonte de solo de $20 \mathrm{~cm}$, cor bruna escura amarelada, (10YR 4/4), textura argilo-pouco arenosa, estrutura granular moderada média, consistência úmida muito friável, e quando molhada, apresenta-se ligeiramente plástica e pegajosa. Apresenta volumes centimétricos de argila com consistência firme, poros muito pequenos são comuns e poucos poros pequenos, presença dominante de raízes finas e poucas raízes de até $5 \mathrm{~mm}$, transição difusa.

2. Horizonte de solo de $40 \mathrm{~cm}$, cor bruna escura amarelada (10YR 4/6), textura argilosa, estrutura granular moderada média, consistência úmida muito friável, molhada a amostra de solo apresenta comportamento ligeiramente plástico e pegajoso, presença comum de nódulos de argila, poros muito pequenos são comuns e poucos poros pequenos, raízes finas de até $1 \mathrm{~mm}$ são raras, e raízes mais grossas de até $2 \mathrm{~mm}$ são também raras, transição gradual. 


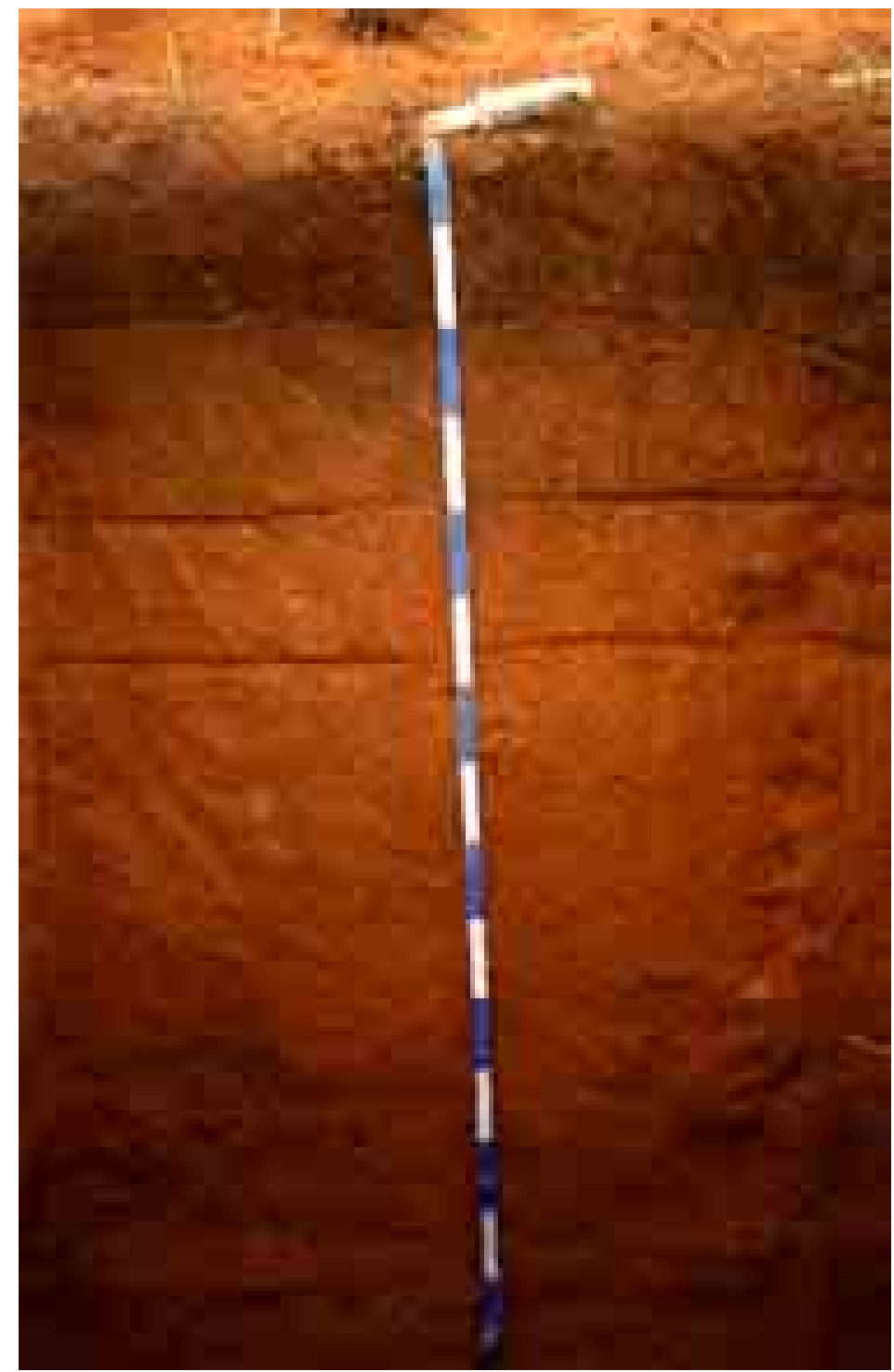

Fotografia $n^{\circ} 13$ Trincheira TRB6 (Castro-Junior-2001) 


\section{Figura nº 20 - Configuração esquemática da trincheira TRB6}

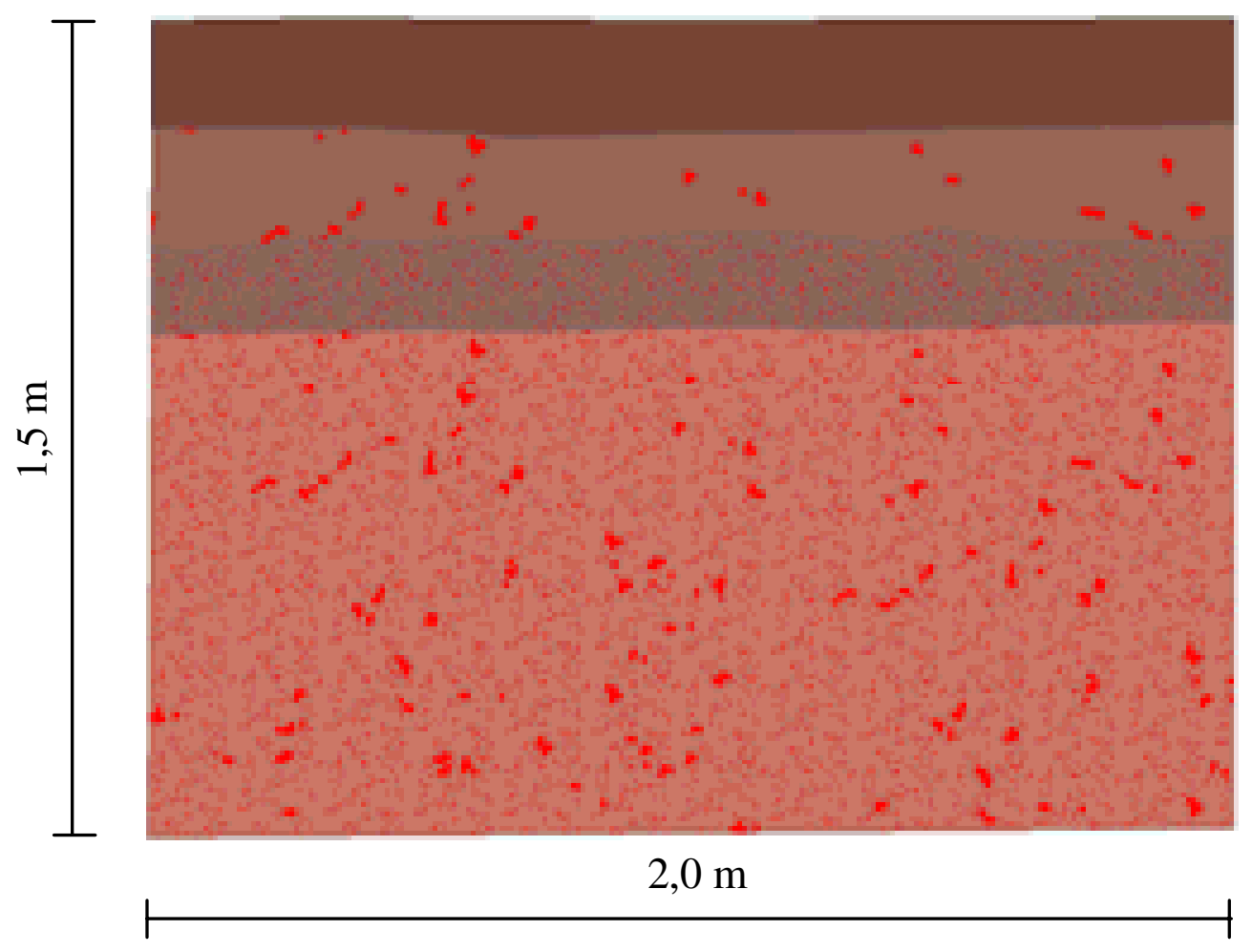

1. Cor bruna escura amarelada, textura argilo-pouco arenosa, estrutura granular moderada média, consistência úmida muito friável, e molhada, é ligeiramente plástica e pegajosa, volumes centimétricos de argila com consistência firme, poros muito pequenos comuns e poucos poros pequenos, presença dominante de raízes finas e poucas raízes de até $5 \mathrm{~mm}$.

2. Cor bruna escura amarelada (10YR 4/5), textura argilosa, estrutura granular moderada média, consistência úmida muito friável, e molhada é ligeiramente plástica e pegajosa, presença comum de nódulos de argila, poros muito pequenos comuns e poucos poros pequenos, raras raízes finas de até $1 \mathrm{~mm}$ e raízes mais grossas de até $2 \mathrm{~mm}$ são também raras.

3. Cor bruna forte (7,5YR 4/4), presença de nódulos milimétricos de argila em menor quantidade que a camada sobrejacente, estrutura granular fraca, grânulos médios, consistência úmida muito friável, e molhada é plástica e ligeiramente pegajososa, presença comum de poros muito pequenos e poucos poros pequenos, poucas raízes de até $1 \mathrm{~mm}$ e raras raízes de $2 \mathrm{~mm}$.

4. Cor bruna forte (7,5YR 5/8), textura argilosa com nódulos centimétricos raros de argila e nódulos milimétricos comuns de argila, estrutura maciça, consistência úmida solta, e molhada é plástica e ligeiramente pegajosa, presença de muitos poros muito pequenos e poucos poros pequenos, poucas raízes finas e raras de até $2 \mathrm{~mm}$. 
3. Horizonte de solo de $17 \mathrm{~cm}$, iniciando aos $40 \mathrm{~cm}$ de profundidade, cor bruna forte (7,5YR 4/4), principal elemento de distinção com a camada sobrejacente, textura argilosa, presença de nódulos milimétricos de argila em menor quantidade que a camada sobrejacente, estrutura granular fraca, grânulos médios, consistência úmida muito friável, molhada a amostra de solo apresenta comportamento plástico e ligeiramente pegajoso, presença comum de poros muito pequenos e poucos poros pequenos, poucas raízes de até $1 \mathrm{~mm}$ e raras raízes de 2 $\mathrm{mm}$, transição difusa.

4. Horizonte de solo com $93 \mathrm{~cm}$ de espessura, iniciando aos $57 \mathrm{~cm} \mathrm{de}$ profundidade, cor bruna forte (7,5YR 5/8), textura argilosa com nódulos centimétricos raros de argila e nódulos milimétricos comuns de argila, estrutura maciça, consistência úmida solta, e molhada é plástica e ligeiramente pegajosa, presença de muitos poros muito pequenos e poucos poros pequenos, poucas raízes finas e raras de até $2 \mathrm{~mm}$.

\subsection{Caracterização analítica do solo}

A caracterização analítica do solo foi feita com base nas análises físicas e químicas das amostras coletadas nas quatro trincheiras da toposseqüência $\mathrm{A}$, cujos resultados são apresentados nos quadros 1,2,3, e 4. As amostras foram processadas no Laboratório Agroanálise, em Cuiabá (MT), participante do Programa de Análise de Qualidade dos Laboratórios de Fertilidade (PAQLF), utilizando os métodos e procedimentos técnicos adotados e recomendados pelo Centro Nacional de Pesquisa de Solos da Embrapa, 1977), bem como pelo Programa de Controle de Qualidade de 
Análise de Solo do Sistema IAC, interpretados de acordo com Tomé Jr (1977).

\subsubsection{Análise Física do Solo}

As características granulométricas das amostras analisadas apresentam um solo argiloso, com teor de argila mínimo de 49,5\% e máximo de $76,2 \%$, sendo que a maioria das amostras situa-se em torno dos $67 \%$.

A grande maioria das amostras apresenta teor de areia em torno de $23,8 \%$, embora o teor mínimo observado seja de $17,2 \%$ e o máximo de 43,8\%. Analisando-se individualmente a fração areia, fica evidente a grande predominância da areia fina, retida na peneira de malha $0,105 \mathrm{~mm}$, sobre as demais classes granulométricas.

A fração silte participa com um percentual em torno de $6,8 \%$.

O horizonte superficial destaca-se dos demais por apresentar teor de areia mais elevado e teor de argila mais baixo, com alto teor de matéria orgânica, o que permite classifica-lo como argila pouco arenosa. Isto se observa melhor nas trincheiras 1 e 2 , onde o solo não foi revolvido por máquinas agrícolas.

As análises mostram também a participação da fração granulométrica seixo, com 2.0-20 $\mathrm{mm}$ de diâmetro, representando as concreções de óxido de ferro ou plintita. Esses valores não alcançam 1\% na trincheira $n^{\circ} 1$, localizada no setor da vertente com evidentes processos de hidromorfia. Nas demais trincheiras, o percentual máximo de seixos situase entre 5,5\% e 6,4\%, correspondendo aos horizontes com maior concentração de plintita. 


\subsubsection{Análise química do solo}

As análises químicas do solo (quadro X) mostram um solo ácido, com $\mathrm{pH}$ obtido em água entre 4.7 - 5.7 e $\mathrm{pH}$ obtido por meio de $\mathrm{CaCl}_{2}$ entre 4.2 - 5.2. A acidez elevada deve-se, provavelmente aos baixos teores de Cálcio e Magnésio, cuja soma de bases apresenta valores em torno de 0.2 $\mathrm{cmol}_{\mathrm{c}} / \mathrm{dm}^{3}$ para a grande maioria das amostras analisadas, com exceção da amostra referente ao horizonte superficial da trincheira 2, área nativa em que o horizonte orgânico superficial por efeito tampão, disponibiliza mais o cálcio e o magnésio. Também o horizonte superficial da trincheira 4 apresenta valor elevado para a soma $\mathrm{Ca}+\mathrm{Mg}$, devido as aplicações de calcário.

Trata-se portanto de um solo argiloso, ácido, com baixos valores de fósforo, potássio, cálcio, magnésio, bem como de matéria orgânica superficial, necessitando de dosagem elevada de corretivos para atingir níveis adequados de saturação dos nutrientes. 


\section{Quadro $n^{\circ}$ 1: Análise Física do Solo}

\begin{tabular}{|c|c|c|c|c|c|c|c|c|}
\hline & $\begin{array}{l}\text { Códigoda } \\
\text { Amostra }\end{array}$ & $\begin{array}{l}\text { Profundi- } \\
\text { dade } \\
\mathrm{cm}\end{array}$ & $\begin{array}{l}\text { Espes- } \\
\text { sura } \\
\mathrm{cm}\end{array}$ & $\begin{array}{c}\text { Bloco \% } \\
20- \\
200 \mathrm{~mm}\end{array}$ & $\begin{array}{c}\text { Seixo } \% \\
2.0- \\
20 \mathrm{~mm}\end{array}$ & $\begin{array}{c}\text { Areia } \% \\
0,05- \\
2.0 \mathrm{~mm}\end{array}$ & $\begin{array}{c}\text { Silte \% } \\
0.002- \\
.05 \mathrm{~mm}\end{array}$ & $\begin{array}{c}\underset{\%}{\text { Argila }} \\
\% \\
\leq 0.002 \\
\mathrm{~mm}\end{array}$ \\
\hline \multirow{6}{*}{$\begin{array}{c}\text { Trincheira } \\
n^{\circ} 1 \\
\text { (TRA1) }\end{array}$} & TRA1.1 & 5 & 10 & 0,0 & 0,0 & 43,8 & 6,7 & 49,5 \\
\hline & TRA1.2 & 20 & 22 & 0,0 & 0,7 & 37,2 & 6,6 & 56,2 \\
\hline & TRA1.3 & 40 & 30 & 0,0 & 0,1 & 27,2 & 6,6 & 66,2 \\
\hline & TRA1.4 & 54 & 22 & 0,0 & 0,0 & 23,8 & 6,7 & 69,5 \\
\hline & TRA1.5 & 80 & 48 & 0,0 & 0,1 & 23,8 & 6,7 & 69,5 \\
\hline & TRA1.6 & 120 & $>16$ & 0,0 & 0,0 & 22,2 & 6,7 & 71,1 \\
\hline \multirow{5}{*}{$\begin{array}{l}\text { Trincheira } \\
n^{\circ} 2 \\
\text { (TRA2) }\end{array}$} & TRA2.1 & 4 & 10 & 0,0 & 2,0 & 33,8 & 6,7 & 59,5 \\
\hline & TRA2.2 & 14 & 20 & 0,0 & 1,5 & 23,8 & 10,0 & 66,2 \\
\hline & TRA2.3 & 42 & 26 & 0,0 & 2,4 & 23,8 & 8,4 & 67,8 \\
\hline & TRA2.4 & 57 & 21 & 0,0 & 6,2 & 25,5 & 6,7 & 67,8 \\
\hline & TRA2.6 & 102 & $>13$ & 0,0 & 2,1 & 23,8 & 6,7 & 69,5 \\
\hline \multirow{10}{*}{$\begin{array}{c}\text { Trincheira } \\
\mathrm{n}^{\circ} 3\end{array}$} & TRA3.1 & 5 & 9 & 0,0 & 0,8 & 23,8 & 5,1 & 71,1 \\
\hline & TRA3.2 & 17 & 16 & 0,0 & 5,5 & 23,8 & 10,0 & 66,2 \\
\hline & TRA3.3 & 37 & 30 & 0,0 & 0,7 & 23,8 & 8,4 & 67,8 \\
\hline & TRA3.4 & 57 & 13 & 0,0 & 2,0 & 23,8 & 6,7 & 69,5 \\
\hline & TRA3.5 & 65 & 24 & 0,0 & 1,4 & 22,2 & 6,7 & 71,1 \\
\hline & TRA3.6 & 77 & 20 & 0,0 & 1,0 & 20,5 & 6,7 & 72,8 \\
\hline & TRA3.7 & 76 & 15 & 0,0 & 0,9 & 22,2 & 6,7 & 71,1 \\
\hline & TRA3.8 & 95 & 30 & 0,0 & 2,8 & 27,2 & 6,6 & 66,2 \\
\hline & TRA3.9 & 112 & 20 & 0,0 & 4,2 & 27,2 & 6,6 & 66,2 \\
\hline & TRA3.10 & 115 & $>9$ & 0,0 & 2,6 & 25,5 & 6,7 & 67,8 \\
\hline \multirow{7}{*}{$\begin{array}{c}\text { Trincheira } \\
n^{\circ} 4\end{array}$} & TRA4.1 & 7 & 13 & 0,0 & 2,2 & 30,5 & 6,7 & 62,8 \\
\hline & TRA4.2 & 23 & 13 & 0,0 & 6,4 & 27,2 & 6,6 & 66,2 \\
\hline & TRA4.3 & 37 & 27 & 0,0 & 1,0 & 20,5 & 6,7 & 72,8 \\
\hline & TRA4.4 & 57 & 20 & 0,0 & 1,8 & 18,9 & 6,6 & 74,5 \\
\hline & TRA4.5 & 83 & 35 & 0,0 & 1,2 & 17,2 & 6,6 & 76,2 \\
\hline & TRA4.6 & 110 & 17 & 0,0 & 2,7 & 23,8 & 8,4 & 67,8 \\
\hline & TRA4.7 & 123 & $>20$ & 0,0 & 0,7 & 23,8 & 6,7 & 69,5 \\
\hline
\end{tabular}


Quadro $n^{\circ}$ 2: Análise Granulométrica da Areia

Percentual de material retido

\begin{tabular}{|c|c|c|c|c|c|c|c|c|}
\hline & $\begin{array}{l}\text { Código } \\
\text { Amostra }\end{array}$ & $\begin{array}{c}\text { Profundidad } \\
\text { e } \\
\mathrm{cm}\end{array}$ & $\begin{array}{c}\text { Espessur } \\
\mathrm{a} \\
\mathrm{Cm}\end{array}$ & $\begin{array}{c}\text { Peneira } \\
1,19 \\
\mathrm{~mm}\end{array}$ & $\begin{array}{c}\text { Peneir } \\
\text { a } 0,5 \\
\mathrm{~mm}\end{array}$ & $\begin{array}{c}\text { Peneir } \\
\text { a } 0,25 \\
\mathrm{~mm}\end{array}$ & $\begin{array}{c}\text { Peneira } \\
0,105 \\
\mathrm{~mm}\end{array}$ & $\begin{array}{c}\text { Peneira } \\
0,052 \\
\mathrm{~mm}\end{array}$ \\
\hline \multirow{6}{*}{$\begin{array}{l}\text { Trincheira } \\
\mathrm{n}^{\circ} 1 \\
\text { (TRA1) }\end{array}$} & TRA1.1 & 5 & 10 & 0,0 & 0,1 & 14,2 & 25,2 & 4,3 \\
\hline & TRA 1.2 & 20 & 22 & 0,0 & 0,3 & 11,9 & 20,8 & 4,2 \\
\hline & TRA1.3 & 40 & 30 & 0,0 & 0,0 & 9,6 & 15,6 & 2,0 \\
\hline & TRA 1.4 & 54 & 22 & 0,0 & 0,0 & 7,9 & 14,3 & 1,6 \\
\hline & TRA 1.5 & 80 & 48 & 0,0 & 0,0 & 8,0 & 14,0 & 1,6 \\
\hline & TRA1.6 & 120 & $>16$ & 0,0 & 0,0 & 6,9 & 13,8 & 1,5 \\
\hline \multirow{5}{*}{$\begin{array}{c}\text { Trincheira } \\
n^{\circ} 2 \\
\text { (TRA2) }\end{array}$} & TRA2.1 & 4 & 10 & 0,0 & 1,2 & 8,0 & 22,2 & 2,4 \\
\hline & TRA2.2 & 14 & 20 & 0,0 & 0,2 & 5,8 & 15,1 & 2,7 \\
\hline & TRA2.3 & 42 & 26 & 0,0 & 0,0 & 5,6 & 15,5 & 2,7 \\
\hline & TRA2.4 & 57 & 21 & 0,0 & 0,0 & 7,6 & 14,7 & 3,2 \\
\hline & TRA2.6 & 102 & $>13$ & 0,0 & 0,0 & 7,4 & 13,6 & 2,8 \\
\hline \multirow{10}{*}{$\begin{array}{l}\text { Trincheira } \\
n^{\circ} 3 \\
\text { (TRA3) }\end{array}$} & TRA3.1 & 5 & 9 & 0,0 & 0,2 & 4,8 & 16,7 & 2,1 \\
\hline & TRA3.2 & 17 & 16 & 0,0 & 0,9 & 7,7 & 12,9 & 2,3 \\
\hline & TRA3.3 & 37 & 30 & 0,0 & 0,8 & 7,3 & 13,6 & 2,1 \\
\hline & TRA3.4 & 57 & 13 & 0,0 & 1,1 & 6,4 & 13,9 & 2,4 \\
\hline & TRA3.5 & 65 & 24 & 0,0 & 0,9 & 6,5 & 12,2 & 2,6 \\
\hline & TRA3.6 & 77 & 20 & 0,0 & 1,6 & 6,4 & 10,4 & 2,1 \\
\hline & TRA3.7 & 76 & 15 & 0,0 & 1,4 & 6,0 & 12,0 & 2,8 \\
\hline & TRA3.8 & 95 & 30 & 0,0 & 1,1 & 5,6 & 18,1 & 2,4 \\
\hline & TRA3.9 & 112 & 20 & 0,0 & 1,5 & 5,3 & 17,8 & 2,6 \\
\hline & $\begin{array}{c}\text { TRA3.1 } \\
0\end{array}$ & 115 & $>9$ & 0,0 & 1,3 & 5,2 & 16,3 & 2,7 \\
\hline \multirow{7}{*}{$\begin{array}{l}\text { Trincheira } \\
n^{\circ} 4 \\
\text { (TRA4) }\end{array}$} & TRA4.1 & 7 & 13 & 0,0 & 0,9 & 9,2 & 18,0 & 2,4 \\
\hline & TRA4.2 & 23 & 13 & 0,0 & 2,4 & 9,8 & 13,0 & 2,0 \\
\hline & TRA4.3 & 37 & 27 & 0,0 & 2,3 & 7,2 & 9,2 & 1,8 \\
\hline & TRA4.4 & 57 & 20 & 0,0 & 1,8 & 6,9 & 8,6 & 1,6 \\
\hline & TRA4.5 & 83 & 35 & 0,0 & 2,1 & 7,1 & 6,8 & 1,2 \\
\hline & TRA4.6 & 110 & 17 & 0,0 & 2,4 & 8,2 & 11,1 & 2,1 \\
\hline & TRA4.7 & 123 & $>20$ & 0,0 & 2,0 & 8,0 & 11,4 & 2,4 \\
\hline
\end{tabular}


Quadro $n^{\circ} 3$ - Análise Química do Solo

\begin{tabular}{|c|c|c|c|c|c|c|c|c|c|c|c|c|c|}
\hline & \multirow{2}{*}{$\begin{array}{l}\text { Código } \\
\text { Amostra }\end{array}$} & \multirow{2}{*}{$\begin{array}{l}\text { Profundidade } \\
\mathrm{cm}\end{array}$} & \multirow{2}{*}{$\begin{array}{c}\text { Espessura } \\
\mathrm{cm}\end{array}$} & \multicolumn{2}{|c|}{$\mathrm{PH}$} & $\mathrm{P}$ & $\mathrm{K}$ & $\mathrm{Ca}+\mathrm{Mg}$ & $\mathrm{Ca}$ & $\mathrm{Mg}$ & $\mathrm{Al}$ & $\mathrm{H}$ & \multirow{2}{*}{$\begin{array}{c}\text { Mat. } \\
\text { Org } \\
\mathrm{g} / \mathrm{dm}^{3}\end{array}$} \\
\hline & & & & Àgua & $\mathrm{CaCl}_{2}$ & \multicolumn{2}{|c|}{$\mathrm{mg} / \mathrm{dm}^{3}$} & \multicolumn{5}{|c|}{$\mathrm{cmol}_{\mathrm{c}} / \mathrm{dm}^{3}$} & \\
\hline \multirow{6}{*}{$\begin{array}{c}\text { Trincheira } \\
n^{\circ} 1\end{array}$} & TRA 1.1 & 5 & 10 & 4.9 & 4.2 & 0.8 & 57 & 0.2 & 0.1 & 0.1 & 1.4 & 10.3 & 32.2 \\
\hline & TRA 1.2 & 20 & 22 & 5.1 & 4.3 & 0.6 & 20 & 0.2 & 0.1 & 0.1 & 0.4 & 7.3 & 19.2 \\
\hline & TRA1.3 & 40 & 30 & 5.5 & 4.8 & 0.6 & 11 & 0.2 & 0.1 & 0.1 & 0.4 & 4.3 & 12.5 \\
\hline & TRA 1.4 & 54 & 22 & 5.5 & 4.8 & 0.6 & 7 & 0.2 & 0.1 & 0.1 & 0.2 & 3.2 & 5.3 \\
\hline & TRA1.5 & 80 & 48 & 5.4 & 4.5 & 0.3 & 5 & 0.2 & 0.1 & 0.1 & 0.2 & 3.0 & 2.9 \\
\hline & TRA1.6 & 120 & $>16$ & 5.4 & 4.6 & 0.3 & 3 & 0.2 & 0.1 & 0.1 & 0.1 & 2.9 & 1.8 \\
\hline \multirow{4}{*}{$\begin{array}{c}\text { Trincheira } \\
\mathrm{n}^{\circ} 2 \\
\text { (TRA2) }\end{array}$} & TRA2.2 & 14 & 20 & 5.2 & 4.3 & 0.6 & 10 & 0.3 & 0.2 & 0.1 & 0.4 & 5.5 & 9.7 \\
\hline & TRA2.3 & 42 & 26 & 5.3 & 4.5 & 0.3 & 5 & 0.1 & 0.1 & 0.0 & 0.3 & 3.5 & 5.7 \\
\hline & TRA2.4 & 57 & 21 & 5.4 & 4.7 & 0.3 & 5 & 0.1 & 0.1 & 0.0 & 0.2 & 2.9 & 2.9 \\
\hline & TRA2.6 & 102 & $>13$ & 5.4 & 4.5 & 0.3 & 3 & 0.1 & 0.1 & 0.0 & 0.2 & 1.2 & 1.4 \\
\hline \multirow{9}{*}{$\begin{array}{c}\text { Trincheira } \\
\mathrm{n}^{\circ} 3 \\
\text { (TRA3) }\end{array}$} & TRA3.1 & 5 & 9 & 5.9 & 4.9 & 1.1 & 20 & 4.1 & 2.3 & 1.8 & 0.0 & 5.1 & 16.3 \\
\hline & TRA3.2 & 17 & 16 & 4.7 & 4.4 & 0.6 & 16 & 0.4 & 0.2 & 0.2 & 0.3 & 4.9 & 10.1 \\
\hline & TRA3.3 & 37 & 30 & 4.6 & 4.5 & 0.6 & 6 & 0.3 & 0.2 & 0.1 & 0.2 & 4.7 & 7.8 \\
\hline & TRA3.4 & 57 & 13 & 4.6 & 4.5 & 0.6 & 8 & 0.3 & 0.2 & 0.1 & 0.2 & 4.4 & 7.0 \\
\hline & TRA3.6 & 77 & 20 & 4.8 & 4.6 & 0.3 & 4 & 0.2 & 0.1 & 0.1 & 0.1 & 4.0 & 5.7 \\
\hline & TRA3.7 & 76 & 15 & 4.7 & 4.5 & 0.3 & 7 & 0.2 & 0.1 & 0.1 & 0.1 & 3.5 & 5.3 \\
\hline & TRA3.8 & 95 & 30 & 5.0 & 4.8 & 0.3 & 16 & 0.1 & 0.1 & 0.0 & 0.1 & 2.8 & 4.1 \\
\hline & TRA3.9 & 112 & 20 & 5.1 & 5.1 & 0.3 & 16 & 0.1 & 0.1 & 0.0 & 0.0 & 2.4 & 2.9 \\
\hline & TRA3.10 & 115 & $>9$ & 5.7 & 5.8 & 0.3 & 7 & 0.1 & 0.1 & 0.0 & 0.0 & 1.1 & 2.2 \\
\hline \multirow{7}{*}{$\begin{array}{c}\text { Trincheira } \\
\mathrm{n}^{\circ} 4 \\
\text { (TRA4) }\end{array}$} & TRA4.1 & 7 & 13 & 5.6 & 4.8 & 4.4 & 50 & 4.8 & 3.6 & 1.2 & 0.0 & 7.1 & 25.8 \\
\hline & TRA4.2 & 23 & 13 & 5.3 & 4.6 & 1.1 & 43 & 1.1 & 0.7 & 0.4 & 0.2 & 5.8 & 13.6 \\
\hline & TRA4.3 & 37 & 27 & 5.4 & 4.8 & 0.6 & 17 & 0.7 & 0.5 & 0.2 & 0.1 & 3.6 & 11.6 \\
\hline & TRA4.4 & 57 & 20 & 5.3 & 5.0 & 0.6 & 11 & 0.7 & 0.5 & 0.2 & 0.1 & 3.9 & 8.7 \\
\hline & TRA4.5 & 83 & 35 & 5.2 & 5.1 & 0.3 & 6 & 0.7 & 0.5 & 0.2 & 0.0 & 3.3 & 5.3 \\
\hline & TRA4.6 & 110 & 17 & 5.0 & 5.2 & 0.3 & 5 & 0.5 & 0.3 & 0.2 & 0.0 & 2.9 & 2.9 \\
\hline & TRA4.7 & 123 & $>20$ & 5.2 & 5.4 & 0.3 & 5 & 0.3 & 0.2 & 0.1 & 0.0 & 1.9 & 1.1 \\
\hline
\end{tabular}


Quadro $n^{\circ} 4$ - Cálculos das Determinações Analíticas

\begin{tabular}{|c|c|c|c|c|c|c|c|c|c|c|c|c|c|c|}
\hline & \multirow{2}{*}{$\begin{array}{l}\text { Código } \\
\text { Amostra }\end{array}$} & \multirow[t]{2}{*}{ Espessura } & \multirow[t]{2}{*}{ Profundidade } & $\begin{array}{c}\text { Soma } \\
\text { de }\end{array}$ & $\mathrm{CTC}$ & \multirow{2}{*}{$\begin{array}{c}\text { Saturaçã } \\
\text { o } \\
\text { por bases } \\
\% \\
\%\end{array}$} & \multicolumn{3}{|c|}{ Relações } & \multicolumn{4}{|c|}{ Saturação(\%) por } & \multirow{2}{*}{$\begin{array}{c}\text { Sat. Al } \\
\mathrm{m} \%=\mathrm{Al} \div(\mathrm{al}+\mathrm{S}) \times 10 \\
0\end{array}$} \\
\hline & & & & \multicolumn{2}{|c|}{$\mathrm{cmol}_{\mathrm{c}} / \mathrm{dm}^{3}$} & & $\mathrm{Ca} / \mathrm{Mg}$ & $\mathrm{Ca} / \mathrm{K}$ & $\mathrm{Mg} / \mathrm{K}$ & $\mathrm{Ca}$ & $\mathrm{Mg}$ & $\mathrm{K}$ & $\mathrm{H}$ & \\
\hline \multirow{6}{*}{$\begin{array}{c}\text { Trincheira } \\
n^{\circ} 1\end{array}$} & TRA1.1 & 5 & 10 & 0.3 & 12.0 & 2.9 & 1.3 & 0.8 & 0.7 & 1.0 & 0.8 & 1.2 & 85.6 & 79.8 \\
\hline & TRA1.2 & 20 & 22 & 0.3 & 7.9 & 3.2 & 1.2 & 1.9 & 1.6 & 1.3 & 1.1 & 0.7 & 92.0 & 59.8 \\
\hline & TRA1.3 & 40 & 30 & 0.2 & 4.9 & 4.7 & 1.3 & 3.0 & 2.3 & 1.8 & 1.4 & 0.6 & 87.6 & 62.1 \\
\hline & TRA1.4 & 54 & 22 & 0.2 & 3.6 & 6.1 & 1.1 & 3.8 & 3.4 & 1.9 & 1.7 & 0.5 & 88.4 & 47.8 \\
\hline & TRA1.5 & 80 & 48 & 0.2 & 3.5 & 6.2 & 1.0 & 5.0 & 4.8 & 1.9 & 1.8 & 0.4 & 88.1 & 48.4 \\
\hline & TRA1.6 & 120 & $>16$ & 0.2 & 3.2 & 6.5 & 1.0 & 7.7 & 7.4 & 1.9 & 1.8 & 0.2 & 89.6 & 37.6 \\
\hline \multirow{5}{*}{$\begin{array}{c}\text { Trincheira } \\
\mathrm{n}^{\circ} 2 \\
\text { (TRA2) }\end{array}$} & TRA2.1 & 4 & 10 & 2.4 & 13.6 & 17.5 & 1.1 & 3.8 & 3.6 & 7.7 & 7.3 & 2.0 & 78.9 & 17.4 \\
\hline & TRA2.2 & 14 & 20 & 0.3 & 6.2 & 5.3 & 1.3 & 5.8 & 4.5 & 2.4 & 1.9 & 0.4 & 88.7 & 53.5 \\
\hline & TRA2.3 & 42 & 26 & 0.1 & 3.9 & 2.9 & 1.5 & 5.8 & 3.8 & 1.9 & 1.3 & 0.3 & 90.6 & 68.9 \\
\hline & TRA2.4 & 57 & 21 & 0.1 & 3.2 & 3.5 & 1.3 & 4.6 & 3.5 & 1.9 & 1.4 & 0.4 & 90.3 & 63.9 \\
\hline & TRA2.6 & 102 & $>13$ & 0.1 & 1.5 & 7.3 & 1.2 & 6.4 & 5.3 & 3.4 & 2.8 & 0.5 & 79.2 & 65.0 \\
\hline \multirow{10}{*}{$\begin{array}{c}\text { Trincheira } \\
\mathrm{n}^{\circ} 3 \\
\text { (TRA3) }\end{array}$} & TRA3.1 & 5 & 9 & 4.2 & 9.3 & 44.8 & 1.2 & 43.3 & 35.1 & 24.3 & 19.7 & 0.6 & 55.2 & 0.0 \\
\hline & TRA3.2 & 17 & 16 & 0.4 & 5.6 & 7.9 & 1.2 & 4.8 & 4.0 & 3.6 & 3.0 & 0.7 & 87.6 & 36.1 \\
\hline & TRA3.3 & 37 & 30 & 0.3 & 5.2 & 6.1 & 1.5 & 10.9 & 7.4 & 3.3 & 2.2 & 0.3 & 90.1 & 38.8 \\
\hline & TRA3.4 & 57 & 13 & 0.3 & 4.9 & 6.5 & 1.3 & 7.2 & 5.6 & 3.0 & 2.3 & 0.4 & 89.5 & 38.4 \\
\hline & TRA3.5 & 65 & 24 & 0.2 & 4.6 & 4.8 & 1.3 & 6.0 & 4.8 & 2.7 & 2.2 & 0.5 & 90.8 & 47.5 \\
\hline & TRA3.6 & 77 & 20 & 0.2 & 4.3 & 4.9 & 1.2 & 9.6 & 8.0 & 2.3 & 1.9 & 0.2 & 92.3 & 37.3 \\
\hline & TRA3.7 & 76 & 15 & 0.2 & 3.8 & 5.7 & 1.3 & 4.7 & 3.6 & 2.2 & 1.7 & 0.5 & 91.1 & 36.4 \\
\hline & TRA3.8 & 95 & 30 & 0.1 & 3.0 & 4.7 & 1.4 & 1.6 & 1.1 & 2.2 & 1.5 & 1.4 & 91.2 & 46.9 \\
\hline & TRA3.9 & 112 & 20 & 0.1 & 2.5 & 5.6 & 1.2 & 1.2 & 1.0 & 2.0 & 1.6 & 1.7 & 94.4 & 0.0 \\
\hline & TRA3.10 & 115 & $>9$ & 0.1 & 1.2 & 9.5 & 1.2 & 2.7 & 2.3 & 4.0 & 3.3 & 1.5 & 90.5 & 0.0 \\
\hline \multirow{7}{*}{$\begin{array}{c}\text { Trincheira } \\
\mathrm{n}^{\circ} 4\end{array}$} & TRA4.1 & 7 & 13 & 4.9 & 12.1 & 40.9 & 3.1 & 27.7 & 8.9 & 29.9 & 9.6 & 1.1 & 59.1 & 0.0 \\
\hline & TRA4.2 & 23 & 13 & 1.2 & 7.2 & 16.8 & 1.6 & 5.8 & 3.7 & 9.0 & 5.8 & 1.6 & 80.4 & 14.2 \\
\hline & TRA4.3 & 37 & 27 & 0.7 & 4.5 & 16.6 & 2.0 & 11.3 & 5.6 & 11.1 & 5.5 & 1.0 & 80.7 & 14.4 \\
\hline & TRA4.4 & 57 & 20 & 0.7 & 4.7 & 15.4 & 1.8 & 15.7 & 8.7 & 9.5 & 5.3 & 0.6 & 81.9 & 14.6 \\
\hline & TRA4.5 & 83 & 35 & 0.7 & 4.0 & 18.0 & 1.8 & 28.8 & 16.0 & 11.3 & 6.3 & 0.4 & 82.0 & 0.0 \\
\hline & TRA4.6 & 110 & 17 & 0.5 & 3.4 & 15.1 & 1.5 & 19.2 & 12.8 & 7.4 & 4.9 & 0.4 & 84.9 & 0.0 \\
\hline & TRA4.7 & 123 & $>20$ & 0.3 & 2.2 & 14.3 & 1.3 & 11.5 & 8.9 & 6.9 & 5.3 & 0.6 & 85.7 & 0.0 \\
\hline
\end{tabular}




\subsection{Classificação dos Solos}

O atual Sistema Brasileiro de Classificação de Solos (Embrapa 1999) classifica os solos estudados nesta pesquisa, de acordo com as classes do $1^{\circ}$ nível categórico ou ordens, em PLINTOSSOLO e LATOSSOLO.

Os PLINTOSSOLOS são solos constituídos por material mineral, com horizonte plíntico ou litoplíntico começando dentro de $40 \mathrm{~cm}$, ou dentro de $200 \mathrm{~cm}$ quando imediatamente abaixo do horizonte $\mathrm{A}$ ou $\mathrm{E}$, ou subjacente a horizontes que apresentam coloração pálida ou variegada, ou com mosqueamentos em quantidade abundante ( $>20 \%$ por volume) e satisfazendo uma das seguintes cores: matizes 2,5 Y ou 5Y; ou matizes 10YR ou 7,5YR, com cromas baixos, normalmente igual ou inferior a 4, podendo atingir 6, no caso de matiz 10YR; ou mosqueados em quantidade abundante, se presentes, devem apresentar matizes e/ou cromas de acordo com os itens a ou b e a matriz do solo tem coloração desde avermelhada até amarelada; ou horizontes de coloração pálida (cores acinzentadas, brancas ou amarelo-claras), com matizes e/ou croma de acordo com os itens a ou b, podendo ocorrer ou não mosqueados de coloração desde avermelhada até amarelada.

No $2^{o}$ nível categórico ou subordens, classificam-se como PLINTOSSOLOS ARGILÚVICOS, devido ao horizonte $B$ textural coincidir com o horizonte plíntico. No $3^{\text {o }}$ nível ou grandes grupos classificam-se como PLINTOSSOLOS ARGILÚVICOS Alumínicos, devido ao caráter alumínico dentro de $100 \mathrm{~cm}$ da superfície do solo, e também como PLINTOSSOLOS ARGILÚVICOS Distróficos, devido a baixa saturação por bases $(\mathrm{V}>50 \%$ ), na maior parte dos primeiros $100 \mathrm{~cm}$

do horizonte B. No $4^{\circ}$ nível categórico ou subgrupos, classificam-se como PLINTOSSOLOS ARGILÚVICOS Alumínicos típicos, por não apresentar mudança textural abrupta ou em PLINTOSSOLOS ARGILÚVICOS 
Distróficos típicos, por não possuir textura arenosa, caráter solódico ou mudança textural abrupta.

Os LATOSSOLOS são solos constituídos por material mineral, apresentando horizonte B latossólico imediatamente abaixo de qualquer tipo de horizonte A, dentro de $200 \mathrm{~cm}$ da superfície do solo ou dentro de $300 \mathrm{~cm}$, se o horizonte A apresenta mais que $150 \mathrm{~cm}$ de espessura.

Com relação ao $2^{\circ}$ nível categórico ou subordens podem ser Latossolo Bruno devido ao matiz mais amarelo que 2,5YR em todo o horizonte B e textura argilosa ou muito argilosa, ou LATOSSOLO VERMELHO, devido ao matiz 2,5YR ou mais vermelho na maior parte dos primeiros $100 \mathrm{~cm}$ do horizonte $\mathrm{B}$.

No $3^{\circ}$ nível categórico ou grandes grupos classifica-se em Latossolo Bruno Distrófico devida a baixa saturação por bases $(\mathrm{V}>50 \%)$ na maior parta dos primeiros $100 \mathrm{~cm}$ do horizonte $\mathrm{B}$. No $4^{\circ}$ nível classificatório ou subgrupos classificam-se como LATOSSOLO BRUNO Distrófico Câmbico por apresentar a soma dos horizontes A + B (inclusive BC), com $150 \mathrm{~cm}$ ou menos de espessura.

O LATOSSOLO VERMELHO, no $3^{\circ}$ nível categórico ou grandes grupos classifica-se em LATOSSOLO VERMELHO-AMARELO Distroférrico devido a saturação por bases baixa $(\mathrm{V}<50 \%)$ e teores de $\mathrm{Fe}_{2} \mathrm{O}_{3}$ (pelo $\mathrm{H}_{2} \mathrm{SO}_{4}$ ) de $18 \%$ a $<36 \%$ na maior parte dos primeiros $100 \mathrm{~cm}$ do horizonte B. No $4^{\circ}$ nível categórico ou subgrupos denomina-se LATOSSOLO VERMELHO Distroférrico plíntico, por apresentar horizonte plíntico em posição não diagnóstica para PLINTOSSOLOS; ou com 5\% ou mais de plintita e/ou petroplintita em um mais horizontes dentro de $150 \mathrm{~cm}$ da superfície do solo.

A característica mais notável destes solos é a presença de concreções ferruginosas formando o horizonte plíntico (do grego plinthos, tijolo), ou 
seja, horizonte de solo contendo mosqueados vermelhos e amarelos, macios quando úmidos, mas que endurecem irreversivelmente quando secam, formando nódulos duros, dentro dos $40 \mathrm{~cm}$, ou até $240 \mathrm{~cm}$, desde que abaixo de horizontes E, com muito mosqueado de redução ou essencialmente petroplíntico é tida como o principal elemento diferencial dos Plintossolos (Embrapa, 1982; Oliveira et al., 1992).

Nas plintitas pode haver concentração de elementos traços, principalmente quando ricas também em manganês e fósforo (Fontes et al., 1985). As raízes têm em geral, dificuldade em se aprofundar nesses sistemas. Não é muito adequado, em especial para plantas perenes, que precisam de água durante o ano todo. (Rezende et al., 1997). Dentro desta classe estão incluídas grande parte das anteriormente chamadas Lateritas Hidromórficas, hoje PLINTOSSOLOS. Apresentam restrições temporárias à percolação da água ou oscilação pronunciada do lençol freático. Sua fertilidade natural é muito variável e nem todo PLINTOSSOLO é hidromórfico.

Nas topossequencias levantadas o horizonte plíntico com concreções endurecidas, está compreendido entre o nível mais elevado e o mais profundo do lençol freático, enquanto que os mosqueados macios vermelhos e amarelos encontram-se nos níveis em que o solo está constantemente saturado. 


\section{A DINÂMICA HÍDRICA}

A dinâmica da água ou estrutura hídrica relaciona-se diretamente com a paisagem local, tendo como principais condicionantes, além das precipitações pluviométricas, as propriedades do subsolo geológico, o arranjo estrutural da cobertura pedológica, as formas de relevo, o tipo de cobertura vegetal e do uso do solo, definindo os balanços hídricos e de energia. (Sette,2000)

Desta forma, a autora observa que em termos de condicionamento hídrico do solo, vertentes convexas e côncavas determinam consideráveis diferenças entre os solos que estão associados a elas, criando contrastes extremos entre os setores de relevo rebaixado. Da mesma forma s cobertura do solo, numa área originalmente composta por floresta utilizada para pastagem geram estruturas térmicas próprias, visto que o albedo - poder difusor da superfície - das florestas situa-se na ordem de $12 \%$, enquanto o dos campos varia entre $16 \%$ a $25 \%$, determinando estruturas hídricas diferentes. As florestas, comparadas aos campos ou pastagens, absorvem mais energia, consomem mais água, uniformizam o escoamento da água no tempo e aumentam a capacidade de armazenamento nos solos.

A estrutura pluvial, uma importante característica climática, relaciona-se ao fatores que originam a chuva, ou seja, a gênese da chuva, sendo a variação anual e o padrão habitual da precipitação a sua expressão mais notável nas diferentes paisagens, interagindo através da vegetação, das formas do relevo, da cobertura pedológica e do uso do solo.

A estrutura pluvial das paisagens, de acordo com Sette (2000) não tem sentido se for vista de forma isolada, entretanto, representada enquanto um elemento da totalidade, assume real importância, pois enquanto a estrutura pluvial está associada à gênese, e esta, ao holorrítmo, a estrutura hídrica 
apresenta-se mais diretamente ligada ao local, onde tanto a cobertura do solo, como o arranjo estrutural definem os balanços hídricos e de energia. A estrutura pluvial do estado de Mato Grosso encontra-se representada na figura.$^{\circ} 21$.

\subsection{Os sistemas atmosféricos atuantes}

Para se ter uma boa compreensão do clima de Mato Grosso é necessário compreender os sistemas atmosféricos atuantes na região, que produzem as estações seca, de abril a setembro, e a chuvosa, de outubro a março. A síntese desse tema é elaborada por Sette (2000) na tese O Holorrítmo e as Interações Trópico-Extratópico na Gênese do Clima e as Paisagens do Mato Grosso, em que a autora ressalta que durante a estação seca, a mudança no padrão estacional, da circulação atmosférica na América do Sul, na passagem do verão para outono-inverno, conduz ao avanço e participação cada vez maior do Anticlone Tropical Atlântico (Alta Subtropical), para o centro do continente. Em sua trajetória de ESSE para WNW, atinge Mato Grosso, através do Subsistema Tropical Atlântico Continentalizado (TAC), com ápice de estabilidade e freqüência em junho, julho, agosto e setembro, quando inicia o movimento contrário, a retirada progressiva desse sistema do Brasil Central, indica uma nova mudança estacional - as primavera.

Ao mesmo tempo há um maior deslocamento e freqüência de participação do Anticlone Polar Continental, que adentra pelo sudoeste e às vezes atinge quase todo o Estado. Na maioria das vezes suas propriedades térmicas estão alteradas, mas mantém a característica de ar muito seco e estável. Assim, o Subsistema Polar Continentalizado, é transformado rapidamente em Tropical Continental Subsidente (TCS). 


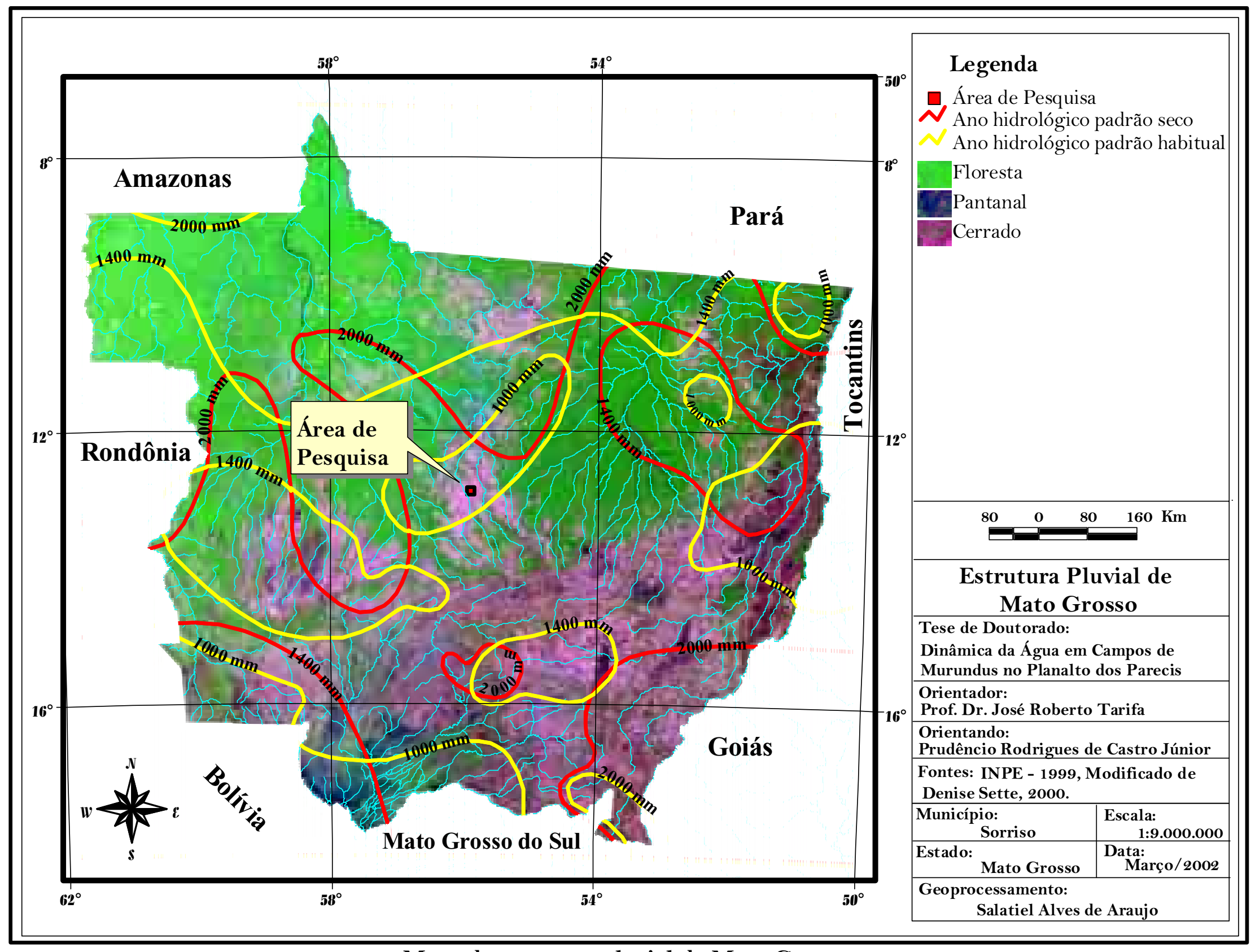

Mapa da estrutura pluvial de Mato Grosso 
Neste regime de alta pressão, verifica-se uma grande diminuição da participação dos Sistemas Tropicais Depressionários (Baixas Continentais) e da convecção associada aos movimentos do Sistema Amazônico e das Linhas de Instabilidade de Norte e Noroeste. A permanência do TAC na área centro oriental, diminui também a participação das Linhas de Instabilidades de Norte e Nordeste, que acompanham o deslocamento da ZCIT para o Hemisfério Norte nesse período. O Sistema Amazônico fica praticamente restrito na sua área de origem, ou simplesmente desaparece. Entretanto, quando se define, atinge no máximo o extremo norte e noroeste do Mato Grosso. O Subsistema Tropical Continental Convectivo (TCC), começa a aparecer no extremo oeste com deslocamento para leste, a partir do final de agosto, quando a superfície do solo no continente já se apresenta com maior aquecimento.

Normalmente os Sistemas Frontais, nesse período, não são capazes de gerar convecção em função das propriedades continentais, ar seco, alta pressão e solo relativamente frio.

Entretanto, a alteração nesse padrão, a exemplo do El Niño, pode conduzir à maior intensidade das chuvas no outono-inverno, principalmente na região sudeste, como aconteceu em junho de 1997, quando os sistemas frontais ficaram mais ativos.

A figura $n^{\circ}{ }^{0} 22$ representa a síntese da participação dos sistemas atmosféricos no Mato Grosso durante a estação seca. A área de maior freqüência de participação (tempo e espaço), está toda colorida, o segundo limite de atuação está representado por linhas com respectiva cor. Para os sistemas convectivos as linhas são tracejadas, enquanto que os sistemas subsidentes as linhas são contínuas. 


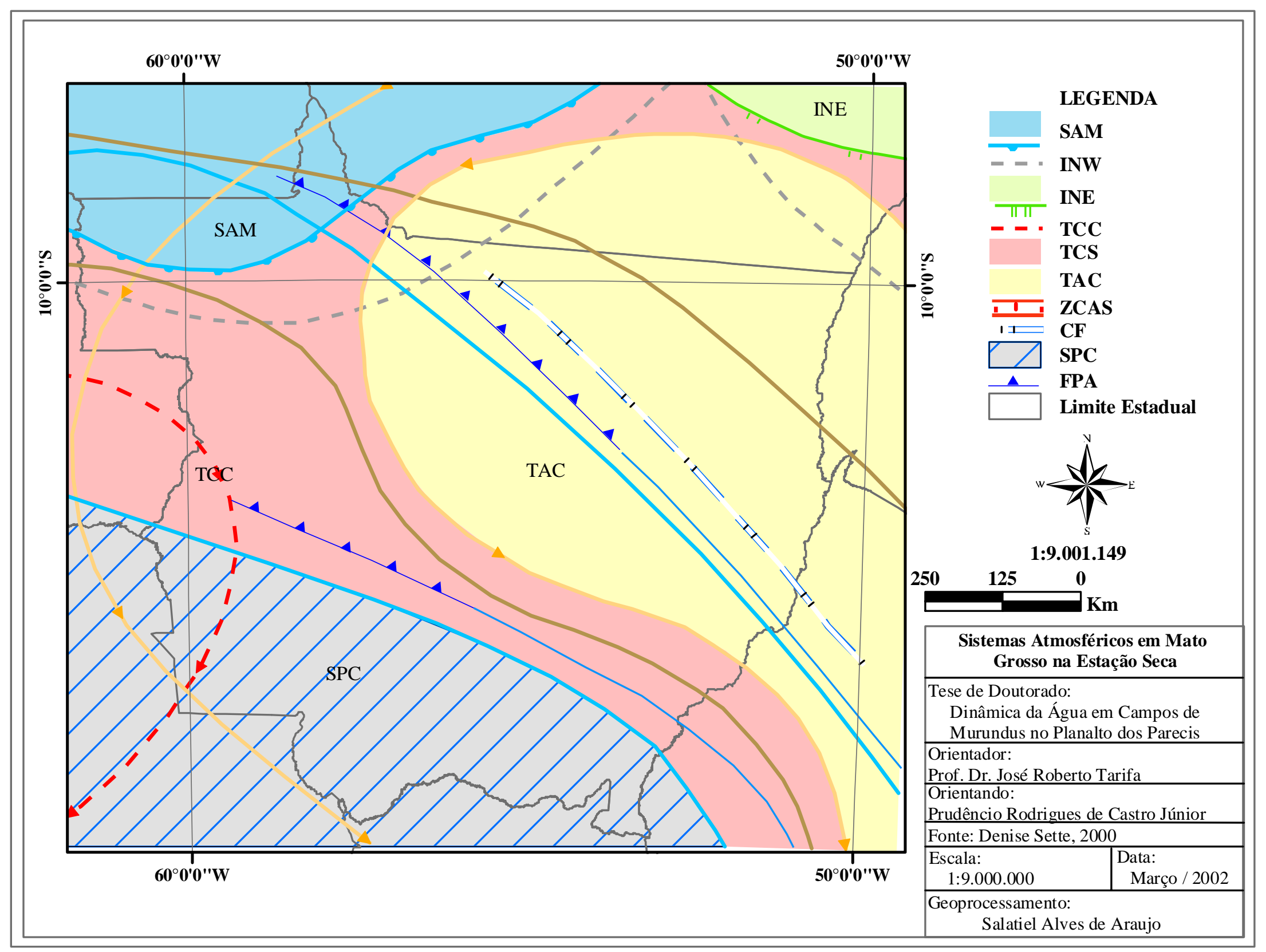

Figura nº 22 - Sistemas atmosféricos na estação seca (Setti, 2000) 
Por outro lado, durante a estação chuvosa, a seqüência do ritmo sazonal, a primavera-verão caracteriza mais uma mudança de padrão, na passagem de um regime de Altas para um regime de Baixas pressões.

O deslocamento para leste da alta Subtropical Atlântica (Sistema Continentalizado), deixa espaço para definição das baixas continentais. Elas são importantes, porque atraem ou aspiram os sistemas Equatoriais (Sistema Amazônico, Instabilidades de Norte e Noroeste e Instabilidades de Norte e Nordeste INW e INE) para o sul. Além disso, são dinamizadas e interligadas pelas calhas e cavados frontais (Sistemas Extratropicais), que dependendo da intensidade das interações e do tempo de permanência desta situação, ocorre às configurações da Zona de Convergência do Atlântico Sul (ZCAS).

Desta forma fica claro que dentro da ZCAS, estão embutidos vários sistemas, entre eles o Sistema Amazônico, as Instabilidades de Norte e Noroeste e as Instabilidades de Norte e Nordeste, que indiretamente fazem parte da ZCIT, Sistema Tropical Continental Convectivo e a Frente Polar Atlântica. A individualização desses sistemas são evidenciados tanto no período que antecede a convergência, como também no processo de desestruturação da mesma.

O Sistema Amazônico, apresenta uma expansão sazonal, com fluxo predominantemente de norte e noroeste, com máximo de atuação em dezembro, janeiro e fevereiro, justamente quando ocorre a penetração dos sistemas equatoriais marítimos, evidenciando-se que a sua gênese é tanto marítima como continental. Seu movimento de (rotação) retração se dá a partir de março.

As Instabilidades de Norte de Nordeste, são importantes na gênese das chuvas na faixa oriental do Estado, elas estão associadas com a 
convergência doa alísios dentro do continente. Descem através do giro dos alísios de sudeste, passando para leste, norte e muitas vezes até noroeste.

A ZCIT, não está representada na síntese da autora, pois a mesma tem uma atuação mais direta no Mato Grosso, ela age diretamente através das INE (Instabilidades de Norte e Nordeste) e também pelo Sistema Amazônico.

Os Sistemas Extratropicais, mesmo quando estão mais ao sul, reforçam a instabilidade e as chuvas no Mato Grosso. A permanência primeira da Convergência Frontal no centro nordeste, também é importante na gênese das chuvas. Pois, mesmo em frontólise (ar polar continental superaquecido), favorece ainda os processos convectivos.

A figura $n .^{\circ} 23$ representa a síntese da precipitação e espacialização dos sistemas atmosféricos no Mato Grosso, na estação chuvosa. Da mesma forma que na estação seca, a área de maior freqüência de participação (tempo e espaço), está colorida, o segundo e até o terceiro limite de atuação estão representados por linhas com a mesma cor. Os sistemas convectivos estão representados por meio de linhas tracejadas, e os sistemas subsidentes com linhas contínuas. 


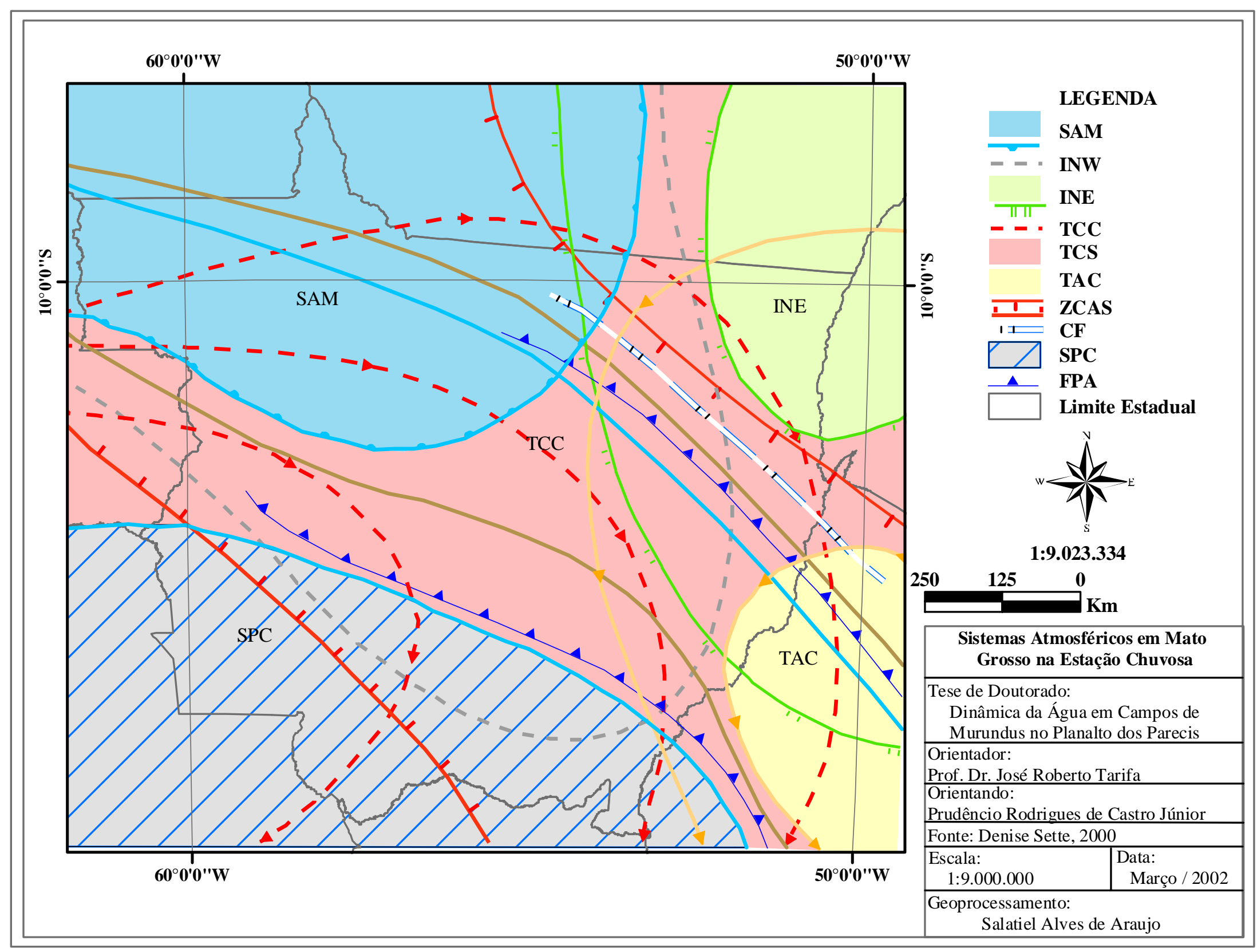

Figura $n^{\circ} 23$ - Sistemas atmosféricos na estação chuvosa (Setti, 2000) 


\subsection{A Estrutura Pluvial do Planalto dos Parecis}

O Planalto dos Parecis é composto originalmente por floresta estacional e gradações do cerrado, com maior complexidade onde a gênese climática não possui configuração única. Trata-se de uma área de extensão ou contígua à atuação dos sistemas intertropicais geradores de chuva, mas ao mesmo tempo é tomada pela atuação direta do Sistema Tropical Atlântico Continentalizado que impõem o regime de seca.

Desta forma, a variação da oferta pluvial em um ano é consideravelmente grande, entre menos de 1.000 até $2.000 \mathrm{~mm}$. Com base nos dados da FEMA-MT, Sette (2000), observa que a alteração da cobertura vegetal no Parecis alcança índices bem elevados, cobrindo no máximo 40\%, entretanto, na região desta pesquisa, no médio rio Telles Pires, encontra-se apenas $20 \%$ com cobertura vegetal natural, onde o solo é utilizado para pastagens e o plantio de culturas temporárias, principalmente soja, milho e arroz.

\subsection{Análise da Pluviosidade em Sorriso}

Os dados pluviométricos do município de Sorriso, fornecidos pela Secretaria Municipal de Agricultura e Meio Ambiente, correspondentes ao período de 15 anos (1986-2001), apresentados no quadro n. ${ }^{\circ} 5$, mostram que durante esses 15 anos a precipitação média anual foi de 2.262,96 mm, sendo que os anos mais chuvosos foram 1986, com 2918 mm, e 1992 com $2919 \mathrm{~mm}$, e o ano menos chuvoso foi 2000, com $1727 \mathrm{~mm}$. 
Quadro 5. Dados pluviométricos do município de Sorriso em $\mathrm{mm}$ 1986-2001

\begin{tabular}{|c|c|c|c|c|c|c|c|c|c|c|c|c|c|c|c|c|}
\hline & 1986 & 1987 & 1988 & 1989 & 1990 & 1991 & 1992 & 1993 & 1994 & 1995 & 1996 & 1997 & 1998 & 1999 & 2000 & 2001 \\
\hline Jan & 638 & 648 & 235 & 393 & 368 & 410 & 190 & 289 & 269 & 493 & 208 & 451 & 268 & 345 & 372 & 337 \\
\hline Fev & 734 & 443 & 486 & 266 & 354 & 259 & 507 & 397 & 469 & 497 & 373 & 398 & 411 & 262 & 301 & $\begin{array}{c}262 . \\
5\end{array}$ \\
\hline Mar & 374 & 219 & 288 & 417 & 149 & 356 & 337 & 184 & 455 & 350 & 352 & 434 & 355 & 253 & 245.5 & \\
\hline Abr & 219 & 88 & 363 & 109 & 136 & 162 & 377 & 130 & 164 & 158 & 212 & 125 & 124 & 73 & 135 & \\
\hline Mai & - & 77 & 20 & 29 & 124 & 79 & 25 & 08 & - & 70 & 19 & 17 & 03 & 06 & - & \\
\hline Jun & - & - & - & 27 & 03 & - & - & 03 & 68 & - & - & 37 & - & - & - & \\
\hline Jul & - & - & - & 06 & 16 & - & - & - & 03 & - & - & - & - & - & - & \\
\hline Ago & 90 & - & - & 61 & - & - & 106 & 63 & - & - & 23 & - & 50 & 63 & - & \\
\hline Set & - & 50 & - & 46 & 118 & 99 & 174 & 91 & 38 & 45 & 86 & 98 & 70 & 143 & - & \\
\hline Out & 233 & 148 & 245 & 81 & 182 & 247 & 169 & 139 & 246 & 153 & 176 & 181 & 169 & 81.5 & 115.5 & \\
\hline Nov & 311 & 392 & 313 & 196 & 203 & 279 & 228 & 219 & 277 & 482 & 298 & 134 & 481 & 321.5 & 260 & \\
\hline Dez & 319 & 438 & 243 & 607 & 302 & 191 & 506 & 452 & 459 & 233 & 223 & 211 & 334 & 657.5 & 298 & \\
\hline Total & 2918 & 2503 & 2193 & 2217 & 1955 & 2082 & 2919 & 1975 & 2448 & 2481 & 1970 & 2086 & 2265 & 2205.5 & 1727 & \\
\hline
\end{tabular}


A distribuição da pluviosidade ao longo do ano impõe ao local uma das características climáticas mais marcantes, qual seja a existência de duas estações bem definidas: chuvosa (verão - outono) e seca (inverno primavera). Dentro do sistema atmosférico da região, que produz duas estações, a seca compreendendo os meses de abril a setembro, e a chuvosa, entre os meses de outubro a março, observa-se que o período chuvoso estende-se por alguns dias do mês de abril, ocorrendo uma precipitação média de 171,6 mm durante os 15 anos observados, sendo que a maior precipitação observada nesse mês durante esses anos foi de $73 \mathrm{~mm}$ em 1999 e a maior foi de $219 \mathrm{~mm}$ em 1986. Conforme ilustra o gráfico $\mathrm{n}^{\circ} 2$.

Durante esse período chuvoso, os meses que apresentam as maiores precipitações são dezembro, janeiro e fevereiro, sendo que a maior média dos 15 anos é encontrada no mês de fevereiro, com 410,4 mm. Precipitações excepcionais quase habituais ocorreram em janeiro e fevereiro de 1986, com $638 \mathrm{~mm}$ e $734 \mathrm{~mm}$ respectivamente, janeiro de 1987 com $648 \mathrm{~mm}$ e dezembro de 1999 com $657 \mathrm{~mm}$.

O período seco, compreendido entre os meses de abril a setembro, apresenta as menores precipitações nos meses de maio, junho, julho e agosto, registrando-se durante os 15 anos em análise, as respectivas médias de $31,8 \mathrm{~mm}, 9,2 \mathrm{~mm}, 1,6 \mathrm{~mm}$ e $30,4 \mathrm{~mm}$, sendo comuns os anos em que durante esses meses não se registrou nenhuma precipitação. Durante todo o período seco, de abril a setembro, registra-se em média o total de $315 \mathrm{~mm}$, sendo que as menores precipitações médias encontram-se nos meses de junho e julho com os valores respectivos de 9,2 $\mathrm{mm}$ e 1,6 $\mathrm{mm}$.

A chuva no município de Sorriso durante ano de 2000 é mostrada no quadro $\mathrm{n}^{\mathrm{o}}$ 6, e mais especificamente na Fazenda São Fidel durante todo ano de 2000 até fevereiro de 2001 é mostrada no quadro $\mathrm{n}^{\circ} 7$ e pelo gráfico $\mathrm{n}^{\circ} 3$. 


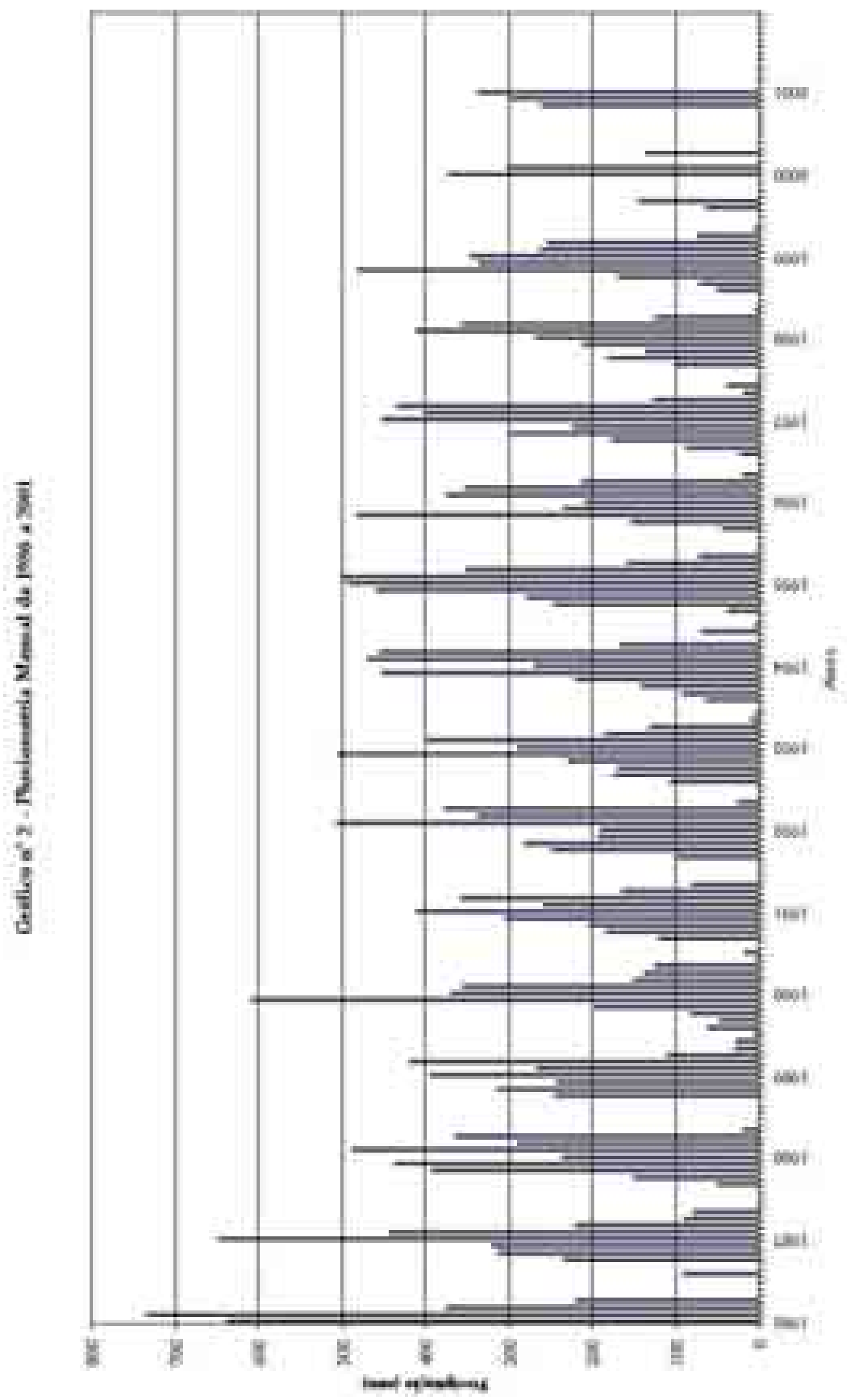


Quadro $n^{\circ} 6$ - Pluviosidade em Sorriso durante o ano 2000

\begin{tabular}{|c|c|c|c|c|c|c|c|c|c|c|c|c|}
\hline Dia & Jan & Fev & Mar & Abr & Mai & Jun & Jul & Ago & Set & Out & Nov & Dez \\
\hline 1 & 10 & - & 4.5 & - & - & - & - & - & - & - & 6 & 52.5 \\
\hline 2 & 52.5 & - & - & - & - & - & - & - & - & - & - & - \\
\hline 3 & - & - & 17.5 & 3.5 & - & - & - & - & - & - & 7.5 & - \\
\hline 4 & 2.5 & 19 & 12.5 & 97.5 & - & - & - & - & - & - & 70 & 60 \\
\hline 5 & - & 51 & - & - & - & - & - & - & - & - & 40 & - \\
\hline 6 & 25 & 9 & 17.5 & 4 & - & - & - & - & - & - & - & 5.5 \\
\hline 7 & 30 & 19 & - & - & - & - & - & - & - & - & 7.5 & 45 \\
\hline 8 & 12.5 & 48 & - & - & - & - & - & - & - & - & - & - \\
\hline 9 & 9 & 6 & 42.5 & - & - & - & - & - & - & - & - & - \\
\hline 10 & - & 4 & - & - & - & - & - & - & - & - & 12.5 & 26 \\
\hline 11 & 5 & 61 & - & - & - & - & - & - & - & - & 55.5 & - \\
\hline 12 & 15 & 4 & 17.5 & - & - & - & - & - & - & - & - & 40 \\
\hline 13 & 50 & 3.5 & 15.5 & - & - & - & - & - & - & - & 7 & 10 \\
\hline 14 & - & - & 43.5 & - & - & - & - & - & - & - & - & - \\
\hline 15 & - & - & 5 & 7 & - & - & - & - & - & - & 17.5 & 25 \\
\hline 16 & 17.5 & 9 & 2.5 & - & - & - & - & - & - & 5.5 & - & 4 \\
\hline 17 & - & - & 9 & 2.5 & - & - & - & - & - & 13 & - & - \\
\hline 18 & - & - & 7 & 1.5 & - & - & - & - & - & - & - & - \\
\hline 19 & - & - & - & - & - & - & - & - & - & - & - & 3 \\
\hline 20 & - & 21 & - & - & - & - & - & - & - & - & - & - \\
\hline 21 & 17 & - & - & - & - & - & - & - & - & - & - & - \\
\hline 22 & 6 & - & - & - & - & - & - & - & - & - & 7.5 & - \\
\hline 23 & - & - & - & - & - & - & - & - & - & - & - & 5 \\
\hline 24 & - & - & - & - & - & - & - & - & - & - & - & 15 \\
\hline 25 & 66 & 7.5 & - & - & - & - & - & - & - & - & 25 & - \\
\hline 26 & 35 & 1.5 & - & - & - & - & - & - & - & - & 4 & 5 \\
\hline 27 & 2.5 & 0.5 & - & - & - & - & - & - & - & 75 & - & 2 \\
\hline 28 & 9 & 5.5 & - & 19 & - & - & - & - & - & - & - & - \\
\hline 29 & 5 & - & - & - & - & - & - & - & - & - & - & - \\
\hline 30 & 2.5 & - & 2 & - & - & - & - & - & - & 2.5 & - & - \\
\hline 31 & - & - & \begin{tabular}{|l|}
49 \\
\end{tabular} & - & - & - & - & - & - & 2 & - & - \\
\hline Total & 372 & 269.5 & 245.5 & 135 & - & - & - & - & - & 115.5 & 260 & 298 \\
\hline
\end{tabular}


Quadro $n^{\circ 7}$ - Pluviosidade na Fazenda São Fidel

janeiro de 2000 a fevereiro de 2001

\begin{tabular}{|c|c|c|c|c|c|c|c|c|c|c|c|c|c|c|c|c|c|c|c|c|c|c|c|c|c|c|c|c|c|c|c|c|}
\hline & 1 & 2 & 3 & 4 & 5 & 6 & 7 & 8 & 9 & 10 & 11 & 12 & 13 & 14 & 15 & 16 & 17 & 18 & 19 & 20 & 21 & 22 & 23 & 24 & 25 & 26 & 27 & 28 & 29 & 30 & 31 & Tota \\
\hline Jan & 23 & 5 & - & - & 20 & - & 40 & 15 & 15 & - & - & - & - & 20 & - & 20 & 5 & - & - & - & - & - & 40 & 5 & 10 & 23 & 13 & - & - & - & - & 254 \\
\hline Fev & - & 3 & - & 5 & 53 & 48 & 80 & - & 3 & 20 & 80 & 5 & 23 & 4 & 9 & 1 & 3 & - & 15 & 1 & 20 & - & - & - & - & - & 40 & - & & & & 413 \\
\hline Mar & - & 26 & 11 & 25 & - & - & - & - & 8 & 40 & 6 & 15 & 18 & - & 3 & 120 & 18 & - & 5 & 3 & 10 & - & - & - & - & - & - & - & - & - & - & 308 \\
\hline Abr & - & 10 & 14 & - & 12 & 5 & - & - & - & - & - & - & - & - & - & 7 & 2 & - & - & - & - & - & 53 & 8 & - & - & - & 13 & 4 & 4 & & 132 \\
\hline Mai & - & - & - & - & - & 8 & - & - & - & - & - & - & - & - & - & - & - & - & - & - & - & - & - & - & - & - & - & - & - & - & - & 8 \\
\hline Jun & - & - & - & - & - & - & - & - & - & - & - & - & - & - & - & - & - & - & - & - & - & - & - & - & - & - & - & - & - & - & & 0 \\
\hline Jul & - & - & - & - & - & - & - & - & - & - & - & - & - & - & - & - & - & - & - & - & - & - & - & - & - & - & - & - & - & - & - & 0 \\
\hline Ago & - & - & - & - & - & - & - & - & - & - & - & - & - & - & - & - & - & - & - & - & - & - & - & - & - & - & - & - & - & - & - & 0 \\
\hline Set & - & - & - & - & - & - & - & - & 5 & - & - & - & - & - & - & 17 & - & - & - & - & - & - & 5 & - & - & - & - & - & 5 & 27 & & 59 \\
\hline Out & - & - & - & - & 5 & - & - & - & - & - & - & - & - & - & - & - & - & 22 & 10 & 24 & - & 30 & - & 2 & - & 42 & 32 & - & 15 & 10 & - & 192 \\
\hline Nov & 20 & - & 32 & 7 & - & 70 & 15 & - & 22 & - & 38 & - & - & - & - & - & - & - & - & - & - & 42 & - & - & - & - & - & - & - & - & & 246 \\
\hline Dez & 70 & - & - & - & - & 30 & - & - & 40 & 99 & - & - & - & 10 & 35 & - & - & - & - & 5 & - & - & - & - & - & - & - & - & - & - & - & 289 \\
\hline Jan & - & 20 & - & 20 & - & - & 15 & - & - & - & 40 & - & 15 & - & - & - & - & - & - & - & - & - & - & 49 & - & - & - & - & - & 15 & - & 174 \\
\hline Fev & - & 72 & - & - & - & - & - & 30 & - & - & - & - & - & 10 & - & - & - & - & 84 & - & - & - & - & - & 40 & & & & & & & 236 \\
\hline & & & & & & & & & & & & & & & & & & & & & & & & & & & & & & & & 2311 \\
\hline
\end{tabular}

Coletado por Marcielle Knapik 


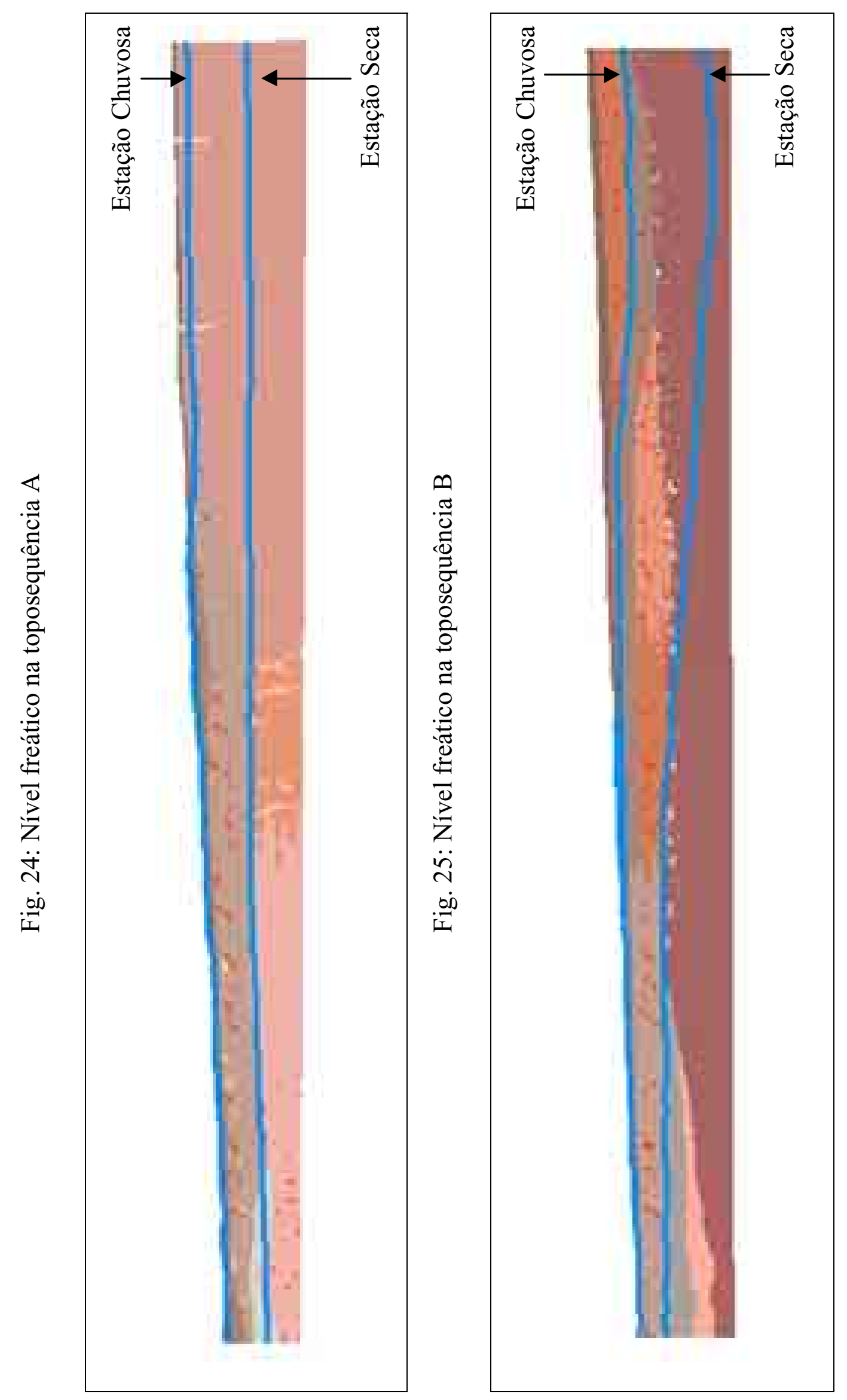




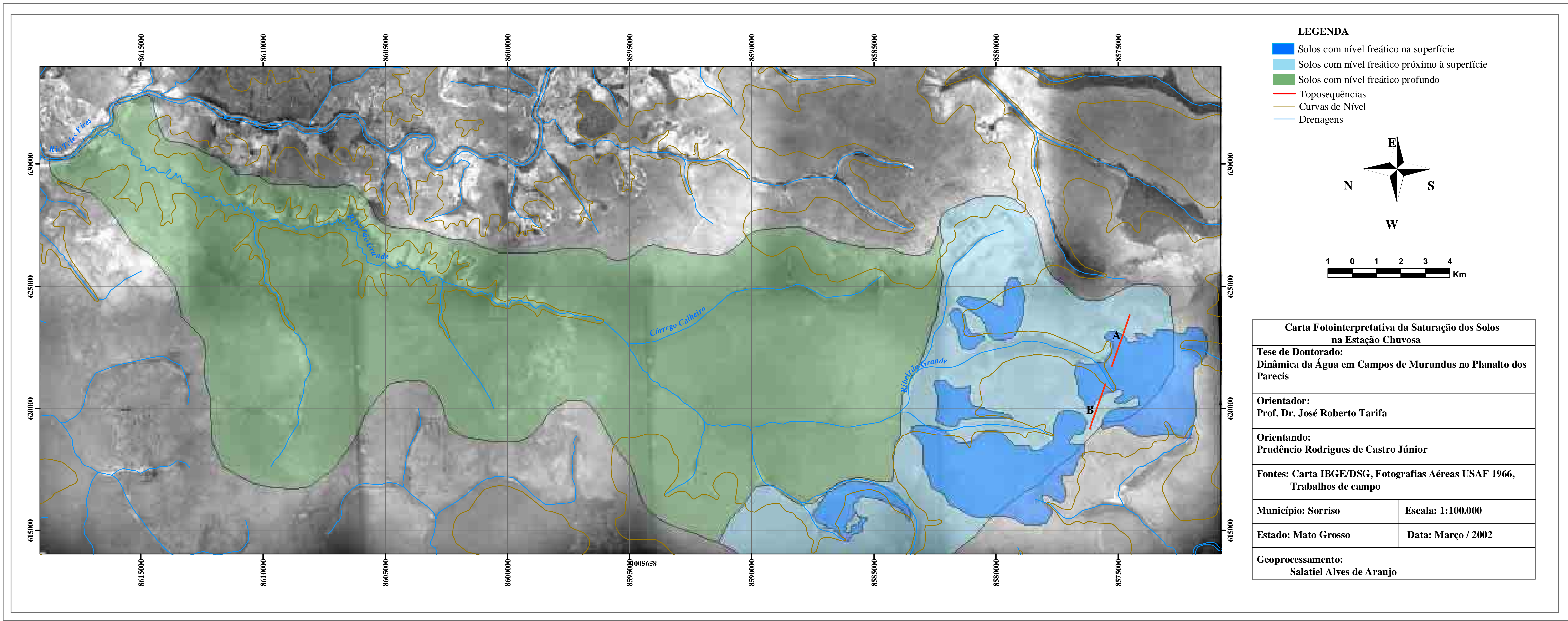


A escavação da rede de drenos com profundidade superior a um metro promove o escoamento de toda a água do lençol suspenso, direcionando-as inteiramente aos canais fluviais em poucas horas após cessar o episódio de chuva. Se por um lado essa intervenção no meio ambiente favorece agricultura em solos naturalmente impróprios, por outro lado, elimina completamente um extenso corpo d'água que continuamente abastece as nascentes e cursos d'água de $1^{\text {a }}$ ordem durante os seis meses secos, atribuindo-lhes perenidade.

O secamento dos campos de murundus do Planalto dos Parecis, por meio dessa rede de canais escavados e a sua substituição por lavoura mecanizada, é bem discutível, pois se por um lado aumenta a produção agro-industrial para exportação e consequentemente a renda do município, por outro lado, pode levar à intermitência, ou mesmo ao secamento, os cursos d'água formadores da bacia hidrográfica, no caso desta pesquisa, a bacia do Telles Pires, integrante da bacia amazônica, contribuindo seriamente com a maior escassez de água, recurso natural imprescindível à vida em nosso planeta, que está cada vez mais escasso, devido a intervenções impactantes ao meio ambiente e a utilização incorreta do solo.

A implantação desses drenos deve estar restrita à faixa acima do ponto de interceptação entre os dois lençóis, sem atingir o lençol freático perene, evitando o escoamento da água subsuperficial em fluxo concentrado, formando piping, que já manifesta alguns indícios em certos canais observados, sendo o principal responsável por perigosas formas erosivas como as boçorocas, de difícil controle. 


\section{CONSIDERAÇÕES FINAIS}

A origem dos murundus é explicada por duas teorias, uma relacionada a fatores bióticos, ou seja, a atividade de três espécies de térmitas, cada qual ligada a determinada fase da construção do microrrelevo, enquanto a outra teoria atribui a origem dos murundus a processos do meio físico, especialmente a erosão de antigas rampas coluviais seccionando a parte inferior das encostas durante a época Holoceno do período Quaternário, ou seja, durante os últimos 2.500 anos, sendo os murundus relíqueas de um paleorrelevo que remanescem nos sítios onde se instalaram os cupinzeiros. Nos campos de murundus estudados no Planalto dos Parecis as evidências são favoráveis à formação de microrrelevos tanto pela atividade de térmitas quanto pela ação erosiva da água superficial que individualiza pequenas porções de solo que a seguir são cimentados por atividades de insetos e recobertos por vegetação que tende a reter maior volume de solo.

Interpretando fotografias aéreas e imagens de satélite, percebe-se a ampla ocorrência de campos de murundus no Planalto dos Parecis. Estas paisagens ocorrem ao redor de nascentes e contornam cursos d'água de $1^{\text {a }}$ ordem, ou seja, os cursos d'água formadores da bacia hidrográfica, portanto, a parte mais sensível da bacia.

Os murundus apresentam configuração e distribuição distinta em cada setor da vertente, na parte mais próxima ao curso d'água, no terço inferior, são pontiagudos e esparsos, no terço médio são freqüentes e predominam os pontiagudos, no terço superior são freqüentes e aplanados pelo 
revolvimento de tatus e tamanduás que são os termitófagos mais comuns daquele ecossistema. Neste caso é difícil individualizar cada microrrelevo, eles praticamente se tocam e os estratos vegetacionais arbustivo e graminoso misturam-se. Embora estas áreas não estejam mais sob o efeito de inundações sazonais, os microrrelevos fósseis, revolvidos e aplanados, indicam que anteriormente, provavelmente no Holoceno estiveram sob a ação de inundação sazonais e portanto o nível freático está se rebaixando e consequentemente diminuindo a água disponível no solo.

O levantamento dos solos de campos de murundus do Planalto dos Parecis, realizado por meio de procedimentos metodológicos da análise estrutural da cobertura pedológica, envolvendo tradagens e trincheiras, indica a presença de PLINTOSSOLO ARGILÚVICO Alumínico típico na base das vertentes e PLINTOSSOLO ARGILÚVICO Distrófico típico nos terços inferior e médio das vertentes, e LATOSSOLO BRUNO Distrófico câmbico e LATOSSOLO VERMELHO Distroférrico plíntico no terço médio e superior das vertentes.

A característica mais notável destes solos é a presença de concreções ferruginosas formando o horizonte plíntico, mosqueados vermelhos e amarelos macios quando úmidos, mas que endurecem irreversivelmente quando secam, formando nódulos duros dentro dos $40 \mathrm{~cm}-240 \mathrm{~cm}$ de profundidade. As concreções endurecidas ocorrem na faixa de oscilação entre o nível mais profundo do lençol freático, enquanto que os mosqueados macios vermelhos e amarelos encontram-se no nível de permanente saturação.

Os campos de murundus possuem como uma de suas características próprias o fato de que seus solos apresentam-se saturados ou supersaturados em água, com o lençol freático exfriltando-se na superfície do terreno durante alguns meses do ano. Está característica está diretamente ligada à chuva, que é o atributo climático mais importante destas paisagens. 
No período chuvoso, durante os meses de outubro a março precipitam $85 \%$ a $100 \%$ das chuvas do ano todo, que na região de Sorriso situa-se em torno de $2000 \mathrm{~mm}$ anuais, os $0 \%-15 \%$ de chuva restante precipitam no período seco sem provocar qualquer alteração no nível freático, durante os meses de abril a setembro.

No final do período seco, nos meses de setembro a outubro, após seis meses sem chuva, desaparece o lençol suspenso temporário, com o nível freático a uma profundidade numa profundidade em torno de 1 metro no setor à jusante da encosta, no terço inferior, próximo ao curso d'água e 1,80 $\mathrm{m}$ a 2,00 $\mathrm{m}$ de profundidade no terço médio da encosta. No primeiro mês do período chuvoso os campos de murundus recuperam toda a capacidade de armazenamento, mantendo o nível freático na superfície do terreno durante toda a estação chuvosa, até o final do mês de março.

Durante o período seco, a partir do mês de abril, o nível freático rebaixa-se lenta e continuamente a uma taxa mensal que varia entre $12 \%$ a $22 \%$, chegando ao final do período em setembro/outubro ao seu nível mínimo entre $1,00 \mathrm{~m}$ a $1,80 \mathrm{~m}$ de profundidade.

O comportamento da água no solo dos campos de murundus, de encherse rapidamente elevando-se o nível freático até chegar a exfiltração na superfície do terreno logo nas primeiras precipitações do período chuvoso e de esvaziar-se lentamente durante os 6 meses do período seco, confere a estas paisagens a condição de reservatório natural que armazena no solo a água da chuva para fornece-la lenta e continuamente às nascentes e cursos nos meses em que não há chuva, perenizando assim o setor de cabeceira da bacia hidrográfica.

O estudo realizado evidencia a presença de dois lençóis freáticos, devido a subida da água por dezenas de centímetros após perfurações por tradagens, de uma camada argilosa e seca, tida como a camada confinante. 
Um desses lençóis caracteriza-se como o lençol perene, quando encontra-se nas maiores profundidades ao longo da vertente. $\mathrm{O}$ outro lençol encontra-se suspenso, acima da camada confinante, sendo sazonal, reconhecido em sua plenitude durante os seis meses chuvosos, quando apresenta-se unido ao lençol perene.

Os campos de murundus, devido ao papel perenizador que desempenha junto aos cursos d'água formadores da bacia hidrográfica, bem como às relações intrínsecas entre fauna e flora que caracterizam um ecossistema próprio do maior bioma brasileiro que é o cerrado, que se encontra em processo de descaracterização, devido às lavouras de soja e arroz, deve ser reconhecido como área de preservação permanente, para fins de proteção de manancial hídrico e de parte representativa da fauna e flora do cerrado brasileiro.

O rebaixamento do nível freático dessas áreas por meio de uma rede de canais escavados ao longo da superfície do terreno, possibilitando o uso agrícola, pode causar a médio e longo prazo perdas ambientais irreparáveis, tais como escassez de recursos hídricos, alterações climáticas, além de destruir importante ecossistema que possui uma complexa cadeia relacionada com a fauna e flora que abriga espécies em extinção. 


\section{BIBLIOGRAFIA}

Ab'Sáber, A. N. 1969. Um conceito de Geomorfologia a serviço das pesquisas sobre o Quaternário. São Paulo: IGEO-USP (Geomorfologia, $18)$.

Ab'Sáber, A.N. 1973. A organização natural das paisagens inter e subtropicais brasileiras. Anais do III Simpósio sobre o cerrado. EDUSP/Edgard Blücher.

Abreu, A. M. de.1981. "Catanduva", um problema no norte de Minas, U.F.V. (Brasil), 8 p (mimeogr.).

Almeida, F. F. M. de. 1948. Reconhecimento geomórfico nos planaltos divisores das bacias amazônica e do Prata entre os meridianos $51^{\circ}$ e $56^{\circ}$ WGr. Revista Brasileira de Geografia, Rio de Janeiro, 10(3):397440.jul./set.

Almeida, F. F. M. de. 1954. Geologia do centro-leste mato-grossense. Boletim da Divisão de Geologia e Mineralogia, Rio de Janeiro (150): 197.

Almeida, F.F.M. 1959. Traços gerais da geomorfologia do Centro-Oeste Brasileiro. In: Almeida, F.F.M. \& Lima, M.A. Planalto Centro Ocidental e Pantanal Matogrossense: Guia de Excursão - $18^{\circ}$ Congresso Internacional de Geografia. Rio de Janeiro, Conselho Nacional de Geografia, p. 170. 
Alonso, U.R. 1999. Rebaixamento temporário de aqüíferos. TENOGEO/GEOFIX, Gráfica Lamara, São Paulo, 131 pp.

Araújo Neto, M. D. de. 1981. Solos, água e relevo dos campos de murundus na Fazenda Água Limpa, Distrito Federal. Dissertação de mestrado, Brasília, Universidade de Brasília.

Araújo Neto, M. D. de.; Furley P. A.; Haridasan, M. \& Johnson, C. E. 1986. The "murundus" of the "cerrado" region of Central Brazil. Journal of Tropical Ecology 2: 17-35.

Arshad, M.A. 1981. Physical and Chemical properties of termite mounds of two species of Macrotermes (Isoptera, Termitidae) and the surrounding soils of the semi-arid savanna of Kennya. Soil Science 132: 161-74.

Banerjee, S.P. \& Mohan, S.C. 1976. Some characteristics of termitaria soils in relation to their surroundings in New Forest State, Dehra Dun. The Indian Forester_102: 257-63.

Barbosa, O. et al. 1966. Geologia estratigráfica, estrutural e econômica da área do "Projeto Araguaia". Monografia da Divisão de Geologia e Mineralogia, Rio de Janeiro (19): 1-94.

Blake, G. R. \& Hartge, H. K. 1986. Bulk density. In: Klute, A. (Ed). Methods of soil analysis. Part 1: physical and mineralogical methods. 2 ed. Madison: ASA/SSSA. P. 363-375 il.

Bodot, P. 1967. Étude écologique des termites des savannes de Basse Côte d'Ivoire. Insectes Sociaux 34: 229-58.

Bocquier, G. 1973. Genése et évolution de deux toposequénces de sols tropicux du Tchad, Mem. ORSTOM, n. 62. 
Boulet, R.; Humbel, F. X.; Lucas, Y. 1982. Analyse structurale et cartographie en pédologie. Cah. ORSTOM, sér. Pédol. XIX, 4 : 323339

Boulet, R., Chauvel, A., Lucas, Y., 1984. Les systèmes de transformation en pédologie. AFES, Livre Jubilaire du Cinquantenaire : 167-179.

Boulet, R. 1992. Uma evolução recente da pedologia e suas implicações no conhecimento da gênese do relevo. Anais III Congresso ABEQUABelo Horizonte, 43-58.

Boyer, P. 1975. Action des certains termites constructeurs sur l'évolution de sols tropicaux II. Étude particulière de trois termitières de Bellicositermes et leur action sur le sols tropicaux. Annales de Sciences Naturelles, Zoologie, Paris, $17,273-446$.

Brazão, J. E. M. \& Santos, M. M. 1997. Vegetação. In: Recursos Naturais e Meio Ambiente: Uma visão do Brasil. 2. ${ }^{a}$ ed. IBGE, Rio de Janeiro.

Buerlen, K. A 1959. Geologia da zona de Barra do Garças e Chavantina, Estado de Mato Grosso. Boletim da Divisão de Geologia e Mineralogia, Rio de Janeiro.

Camargo, M.N.; Klamt, E. \& Kauffamn, J.H. 1987. Classificação de solos usada em levantamentos pedológicos no brasil. Separata do Boletim da SBCS, Campinas, 12:11-33.

Castro, S. S. \& Curmi, P. 1987. Bandas onduladas em solos podzólicos Formação Marília: estruturas de transformação pedológica. In: Congresso Brasileiro de Ciência do Sol, 15, Campinas. Resumo e Comunicação 
Castro, S. S., Curmi, P. 1987. Bandas onduladas em solos podzólicos formação Marília: estruturas de transformação pedológica. In: Congresso Brasileiro de Ciência do Solo, 15, Campinas. $\underline{\text { Resumo e }}$ Comunicação.

Chauvel, A. 1977. Recherches sur la transformation des sols ferralitiques dans la zone tropicale a saisons contrastées. ORSTOM, Paris, Série Travaux et Documents, 62, $532 \mathrm{p}$.

Coelho Netto, A. L. 1994. Hidrologia de encosta na interface com a geomorfologia. In : Geomorfologia: uma atualização de bases e conceitos. Guerra, A.J.T. \& Cunha, S.B. (organizadores) - Rio de Janeiro, Bertrand Brasil, 1994.

Cole, M.M. 1960. Cerrado, caatinga and pantanal: the distribution and origin of the savanna vegetation of Brazil. Geographical Journal 126: 168-79.

Correa, G. F. 1989. Les microreliefs murundus et leur environnement pedologique dans l'ouest du Minas Gerais, região do Planalto Central Brasileiro. Universite de nancy I, these, 144pp.

Correa, J. A. \& Couto, E. A. do. 1972. Projeto aluviões diamantíferos de Mato Grosso; Relatório final. Goiânia, DNPM/CPRM, 1972. 2v. (Relatório do Arquivo técnico da DGM.

Cox, G.W. 1984. Mounds of mistery. Natural History 93: 36-45.

Cox, G.W. \& Gakahu, C.G. 1985. Mima-mounds micro-topography and vegetation patterns in Kenyan savannas. Journal of Tropical Ecology 1: 2336. 
Cunha, B. C. C. da et al 1981. Geologia. In: Brasil, Ministério das Minas e Energia. Secretaria Geral. Projeto Radambrasil. Folha SC.22 Tocantins, Rio de Janeiro, Levantamento de Recursos Naturais, 22)

Cunha, C.N.; Campos, M.M. \& Silva, M.Q. 1983. Estudos biológicos preliminares de uma área de cerrado inundável, transição entre cerrado e pantanal. (Mimoso - Santo Antônio de Leverger, MT). Cuiabá, UFMT. 57p.

Dalquest, W.W. \& Scheffer, V.B. 1942. The origin of Mima-mounds of western Washington. Journal of Geology 50: 68-85.

Diniz de Araújo Neto, M. 1981. Solos, água e relevo dos campos de murundus na Fazenda Água Limpa, Distrito Federal. Dissertação de mestrado, Brasília, Universidade de Brasília.

Diniz de Araújo Neto, M.; Furley, P.A.; Haridasan, M. \& Johnson, C.E. 1986. The murundus of cerrado region of Central Brazil. Journal of Tropical Ecology 2: 1735.

Douchaufour, Ph. \& Souchier, B. 1997. Pédologie, Masson, Paris, 477 p.

Egler, I. 1984. Importância dos cupinzeiros de Procornitermes araujoi (Isoptera, Termitidae) na ciclagem de nutrientes em um cerrado de Brasília. Dissertação de mestrado, Brasília, Universidade de Brasília.

Einten, G. 1972. The cerrado vegetation of Brazil. The Botanical Review 38: 201341.

Eiten, G. 1975. The vegetation of the Serra do Roncador. Biotropica 7: 11235. 
Eiten, G. 1883. Classificação da vegetação do Brasil. Brasília. Conselho Nacional do Desenvolvimento Científico e Tecnológico. 305 p.

Einstein, G. 1985. Vegetation near Santa Terezinha, NE Mato Grosso. Acta Amazonica, 15, 275-301.

Embrapa, 1978. Levantamento de reconhecimento dos solos do Distrito Federal. Brasília, Empresa Brasileira de Pesquisa Agropecuária. 445p.

Embrapa 1982. Levantamento de média intensidade de solos e avaliação da aptidão agrícola das terras do Triângulo Mineiro. Bol. de Pesquisa, 1, Rio de Janeiro, 526 p.

Embrapa 1982 Conceituação sumária de algumas classes de solos recém conhecidas nos levantamentos e estudos de correlação do SNLCS. Rio de Janeiro. (Circular Técnica, 1).

Embrapa 1997. Manual de Métodos de Análise de Solo. Centro Nacional de Pesquisas de Solos, Rio de Janeiro, 212 pp, 1v. il.

Embrapa 1999. Sistema Brasileiro de Classificação de Solos. Produção de Informação; Rio de Janeiro, xxvi, 412p. :il.

Ericksen, A. I. \& Lofgren, A. 1940. A Geologia de Goiaz a Cuiabá. Boletim da Divisão de Geologia e Mineralogia, Rio de Janeiro (102):1-40.

Fairbridge, R. W. 1968. Encyclopedia of geomorphology. Stroudsburg, Dowden Hutchinson \& Ross. 125 p.

Ferreira, A.B.H. 1975. Novo dicionário da língua portuguesa. Rio de Janeiro, Nova Fronteira. 1499 p. 
Figueiredo, A. J. de A. et al 1974. Projeto alto Guaporé; relatório final. Goiânia, DNPM/CPRM, 1974. 11v. (Relatório do Arquivo Técnico da DGM, 2323).

Fries, R.E. \& Fries, T.C.E. 1948. Phytosociological researches on Mt. Kenya and Mt. Aberdare, British East Africa. Kungliga Svenska vetenskapsademiens hanlingar 25: 1-83.

Friendrich, R. 1992. Comparação entre os pluviômetros Ville de Paris e Prolab 1 e Prolab 2. ISAM - PUC Paraná, inédito, mimeo, 23 pp.

Fölster, H. \& Huber, O. 1984. Interrelationes suelos-vegetation en el area galipero, Território Federal Amazonas - Venezuela. Caracas, Ministerio del Ambiente y los Recursos Naturales Renovables. 260 p.

Fontes, L. R. 1979. Os cupins. Ciência e Cultura 31: 986-92.

Fontes, M.R.; Rezende. M. \& Ribeiro, A. C. 1985. Concreções Ferruginosas de alguns solos brasileiros I. Caracterização química. Ver. Bras. Ci. Solo, Campinas, 9: 113-117.

Funch, R. R. 1985. A casa dos "bate-cabeça". Ciência Hoje, 4, 11.

Fundação João Pinheiro 1975. Aspectos geomorfológicos da área do Projeto Sagarana. Revista da Fundação João Pinheiro 5: 14-18.

Furley, P.A. 1985. Notes on the soils and plant communities of Fazenda Água Limpa, Brasilia, DF, Brazil. Ocasional Publications N.S. No 5. Edinburgh, Department of Geogrtaphy, University of Edinburgh. 138 p.

Furley, P.A. 1986. Classification and distribuition of murundus in cerrado of Central Brazil. Journal of Biogeography 13:265-8. 
Furley, P. A. 1985. Notes on the soils and plant communities of fazenda Água Limpa (Brasília, D. F. Brasil). Edinburgh, Dept. Geography. Occasional pub. N.S,5.

Furley, P. A. 1986. Classification and distribution of murundus in the cerrado of Central Brazil. J. Biogeography, 13, 265-268.

Gakahu, C.G. \& Cox, G.W. 1984. The occurrence and origin of Mimamound terrains in Kenya. African Journal of Ecology 22: 31-42.

Gash, J.H.C., Nobleman, C.A., Roberts, J.M. and Vitoria, R.L., 1996. Amazonian, Deforestation and Climate, John Wiley \& Sons New York, $611 \mathrm{pp}$.

Hesse, P. R. 1955. A chemical and physical study of soils of termite mounds in East Africa. Journal of Ecology 43: 449-61

Hole, F. D. 1981. Effects of animals on soil. Geoderma 25: 75-112.

Holt, J. A.; Coventry, R.J. \& Sinclair, D.F. 1980. Some aspects of the biology and pedological significance of mound-building termite in a red and yellow earth landscape near Charters Towers, North Queensland. Australian Journal of Soil Resources 18: 97-109.

Humbel 1978. in: ALMEIDA, F.F.M. de \& LIMA, M. A de. Planalto centro-ocidental e pantanal matogrossense; guia de excursão n. ${ }^{\circ} 1,18^{\circ}$ Congresso Internacional de Geografia. Rio de Janeiro, Conselho Nacional de Geografia.

IBDF \& FBCN 1981. Plano de manejo - Parque Nacional da Serra da Canastra. Brasília, Instituto Brasileiro de Desenvolvimento Florestal \& Fundação Brasileira para a Conservação da Natureza. 96 p. 
Kalpagé, F. S. C. P. 1976 Tropical soils classification, fertility and management. London, Butter \& Tenner. 283 p.

King, L.L. 1956. A geomorfologia do Brasil Oriental. Rio de Janeiro. IBGE. Revista Brasileira de Geografia. 18: 147-265.

King, T.J. 1977a The plant ecology og ant-hills in calcareous grasslands I. Patterns of species in relation to ant-hills in southern England. Journal of Ecology 65: 235-56.

King, T.J. 1977b The plant ecology og ant-hills in calcareous grasslands II. Successsion on the mounds. Journal of Ecology 65: 235-56.

King, T.J. 1977c The plant ecology og ant-hills in calcareous grasslands III. Factors affecting the population sizes of selected species. Journal of Ecology 65: 235-56.

Kux, H. J. H.; Brasil, A. E.; \& Franco, M. de S. M. (1979) Geomorfologia. In: Brasil. Departamento Nacional da Produção Mineral. Projeto Radambrasil. Folha SD.20 Guaporé. Rio de Janeiro, 1979. (Levantamento de Recursos Naturais, 19)

Laker, M.C.; Hewitt, P.H.; Nel, A. \& Hunt, R.P. 1982a. Effects of the termite Trinervitermes trinervoids Sjöstedt on the organic carbon and nitrogen contents and particle-size distribuition of soils. Revue d'Écologie et de Biologie du Sol 19: 27-39.

Laker, M. C.; Hewitt, P.H.; Nel, A. \& Hunt, R.P. 1982b. Effects of the termite Trinervitermes trinervoides Sjösted on the $\mathrm{pH}$, electrical conductivities, cation exchange capacities and extractable base content of soils. Fort Hare Papers 7: 275-86. 
Lee, R.E. \& Wood, Y. G. 1971a. Physical and chemical effects on soil of some Australian termites, na their pedological significance. Pedobiologia 11: 376409.

Lee, R.E. \& Wood, Y. G. 1971b Termites and soils. New York, Academic Press. $251 \mathrm{p}$.

Libardi, P. L. 1984. Dinâmica da água no sistema solo-planta-atmosfera. Piracicaba: CENA. 232 p.

Lima, S. C. 1996. As veredas do ribeirão Panga no triângulo mineiro e a evolução da paisagem. Departamento de Geografia, FFCL, Universidade de São Paulo, dissertação de mestrado, 260 p.

Macedo, J. \& Bryant, R.B. 1987. Morphology, mineralogy and genesis of na hydrosequence of oxisols in Brazil. Soil. Sci. Soc. Am. J., 51, 690698.

Macedo, J. \& Bryant, R.B. 1989. Preferential microbial reduction of hematite over goethite in brazilian Oxisol. Soi. Sci. Soc. Am. J., 53, 1114-1118.

MacWilliam A.L.C., Roberts, J.M., Cabral, M.R, Pig, M.V.B.R., Costa, A.C.L. of the, Maitelli, G.T. and Zamparoni, C.A.G.P. 1993. Leaf area index and above-ground biomass of earth rainforest and adjcent clearings in Amazonian, Functional Ecology, 7: 310-317.

Maitelli, G.T. and Miranda, B.C., 1991. Evapotranspiração e Fluxos de Energia em um cerrado na estação chuvosa, Annals of the Brazilian Academy of Sciences, 63(3): 265-272.

Maitelli, G.T., 1987. Balanço de Energia e Evapotranspiração de um cerrado (sensu strictu) no DF: estação chuvosa. Dissertation of 
Mestrado in Ecology, Department of Biology, University of BrasíliaDF.

Mathews, A.G.A.1977. Studies on termites from the Mato Grosso State, Brazil. Rio de Janeiro, Academia Brasileira de Ciências. 267 p.

Melo, D. P. de \& Costa, R. C. R. de \& Natali-Filho, T. 1978. Geomorfologia. In: Brasil. Departamento Nacional da Produção Mineral. Projeto Radambrasil. Folha SC.20 Porto Velho, Rio de Janeiro, 1978. 663p. (levantamento de Recursos Naturais, 16) p. 185250.

Midena, A.R. \& Van Vuure, W. 1977. The morphological, physical and chemical properties of two mounds of Macrotermes bellicosus (Smeathman) compared with surrounding soils in Sierra Leone. Journal of Soil Science 28: 112-24.

Moore, C.J. and Fisch, G., 1986. Estimating heat storage in Tropical Amazonian Forest, Agricultural and Forest Meteorology, 38: 147-169.

Munsell (1975) Munsell Soil Color Charts, U.S. Dept. Agriculture Handbook 18 - Soil Survey Manual. Munsell Color Macbeth a Division of Kollmorgen Corporation 2441 North Calvert Street, Baltimore, Maryland 21218.

Newcomb, R.C. 1952. Origin of mima-mounds, Thurston County region, Washington. Journal of Geology 60: 461-73.

Olivatti, O \& Ribeiro-Filho, W 1976. Revisão da geologia do centro-norte de Mato Grosso; projetos centro-oeste de Mato Grosso, alto Guaporé e Serra Azul. Goiânia, DNPM/CPRM. 
Oakes, H. \& Thorp, J. 1951. Dark-clay soils of warm regions variousally called Rendzina, Black Cotton soils, Regur and Tirs. Soil Science Society of America Proceedings 15: 347-54.

Oliveira-Filho, A.T. 1988. A vegetação de um campo de monchões microrrelevos associados a cupins na região de Cuiabá (MT). Instituto de Biologia, Universidade Estadual de Campinas, tese de doutoramento, $168 \mathrm{p}$.

Oliveira, E. P. 1915. Geologia; reconhecimento geológico do noroeste de Mato Grosso, Expedição Scientífica Roosevelt-Rondon. Rio de Janeiro, 82 p. (Brasil. Commissão de Linhas Telegráficas e Estratégicas de Mato Grosso ao Amazonas, anexo 1, publ. 50)

Ojany, F.F. 1968. The mound topography of the Thika and Athi Plains of Kenya: a problem of origin. Erdkunde 22: 269-75.

Oliveira, J.B.; Jacomine, P.K.T. \& Camargo, M.N. 1992. Classes gerais de solos do Brasil. Jaboticabal, FUNEP, 201p.

Oliveira, M.AM 1964. Reconhecimento geológico na região noroeste da bacia sedimentar do Paraná. Ponta Grossa, PETROBRÁS-DEBSP, 47p. (Relatório Técnico Interno, 2025)

Oliveira-Filho, A. T. de. \& Furley, P. A. 1990. Monchão, Cocoruto, Morundu. Ciência Hoje, vol. 11/nº 61, 30-37.

Oliveira-Filho, A. T. de. 1988. A vegetação de um campo de monchões microrrelevos associados a cupins na região de Cuiabá (MT). Tese de doutoramento IB-UNICAMP, Campinas, SP, 168 p. 
Parker, L.W.; Fowler, H.G.; Ettershank, G. \& Whitford, W.G. 1982. The effects of subterranean termite removal on desert soil nitrogen and ephemeral flora. Jounal of Arid Environments 5: 53-9.

Pathk, A.N. \& Lehri, L.K. 1959. Studies on temite nests I. Chemical, physical and biological characteristics of a termitarium in relation to its surroundings. Journal of the Indian Society of Soil Science 7: 87-90.

Penteado-Orellana, M.M. 1980. Microrrelevos associados a térmitas no cerrado. Notícias Geomorfológicas 20: 61-71.

Péwé, T.L. 1948. Origin of Mima Mounds. Science Monthly 66: 293-6.

Pommery, D.E. 1983. Some effects of mound-building termites on the soils of a semi-arid area of Kenya. Journal of Soil Science 34: 555-70.

Ponce, V.M. \& Cunha, C.N. 1993. Vegetated earthmounds in tropical savannas of Central Brazil: a syntesis. Journal of Biogeography 20, 219-225.

Prance, G.T. \& Schaller, G.B. 1982. Preliminary study of some vegetation types of the Pantanal, Mato Grosso, Brazil. Brittonia 32: 228-51.

Pullan, R.A. 1979 Termite hills in Africa: their characteristics and evolution. Catena 6: 267-91.

Queiroz Neto, J. P. de. 1988. Análise estrutural da cobertura pedológica no Brasil In: CONGRESSO BRASILEIRO DE CIÊNCIA DO SOLO, 21, 1988. Campinas. Anais ... Campinas: SBCS. P. 414-430.

Queiroz Neto, J. P. de., Castro, S. S., Fernandes Barros, O. N., Manfredini, S., Pellerin, J., Ruellan, A., Toledo, G. S. 1881. Um estudo da dinâmica 
do solo: formação de perfis com horizonte B Textural. In: Congresso Brasileiro de Ciência do Solo, 1981, Salvador. Comunicação.

Radambrasil. 1981. Folha SC.22 Tocantins; geologia geomorfologia, pedologia, vegetação e uso potencial da terra. Ministério das Minas e Energia, Rio de Janeiro, 524 p, il., 6 mapas.

Radambrasil. 1981. Folha SC.22 Goiás; geologia geomorfologia, pedologia, vegetação e uso potencial da terra. Ministério das Minas e Energia, Rio de Janeiro, 640 p, il., 5 mapas.

Radambrasil. 1981. Folha SC.21 Cuiabá; geologia geomorfologia, pedologia, vegetação e uso potencial da terra. Ministério das Minas e Energia, Rio de Janeiro, 554 p, il., 5 mapas.

Radambrasil. 1982. Folha SC.21 Corumbá; geologia geomorfologia, pedologia, vegetação e uso potencial da terra. Ministério das Minas e Energia, Rio de Janeiro, 452 p, il., 5 mapas

Ratter, J.A.; Richards, P.W.; Argent, G. \& Gifford, D.R. 1973. Observations on the vegetation of northeastern Mato Grosso I. The woody vegetation types of the Xavantina-Cachimbo Expedition area. Philosophical Transactions of the Royal Society of London. B. Biological Sciences, 266; 449-92.

Rezende, M.; Curi, N.; Rezende, S. B. \& Corrêa, G. F. 1997. Pedologia: base para distinção de ambientes. 2. ed. - Viçosa : NEPUT. 367p. il.

Ribeiro-Filho, W. et al 1975. Projeto serra Azul; relatório final. Goiânia, DNPM/CPRM, 4v. (Relatório do Arquivo Técnico da DGM, 2407) v.1.

Ritchie, A.M. 1953. The erosional of the Mima mounds of southwest Washington. Journal of Geology 61: 41-50. 
Ross, J.L.S. 1992. O registro cartográfico dos fatos geomórficos e a questão da taxonomia do relevo. Revista do Departamento de Geografia da Faculdade de Filosofia, Letras e Ciências Humanas da USP, ISSN 0102 -4582, São Paulo, 17-29 p.

Roy-Nöel, J. 1979. Termites and soil properties. In: Huxley, P.A., ed. Procedings of the Soils Consultive Meeting, Nairobi, International Council for Research in Agroforestry. p. 271-95.

Roxo, M.G. de O. 1937. Notas Geológicas sobre a Chapada de Mato Grosso. Notas Preliminares e Estudos do Serviço Geológico e Mineralógico, Rio de Janeiro (15):4-7, set.

Ruellan, Alain \& Dosso Mireille. 1993. Regards sur le sol. Les Éditions Foucher, Paris

Salick, J. ; Herrera, R. \& Jordan, C.F. 1983. Termitaria: nutrient-deficient rain forests. Biotropica 15: 1-7.

Salomão, F. X. T. 1994. Processos Erosivos Lineares em Bauru (SP): Regionalização Cartográfica aplicada ao Controle Preventivo Urbano e Rural. São Paulo. (Tese de Doutoramento FFLCH-USP. Departamento de Geografia).

Santos, A. R. dos; Prandini, F. L. \& Oliveira, A. M. S. 1990. Limites ambientais do desenvolvimento: geociências aplicadas, uma abordagem tecnológica da biosfera. ABGE, artigo técnico, 20 p.

Santos, L. S. C. 1995. Sistemas de transformação pedológica em Bauru, SP. São Paulo. (Dissertação de Mestrado - Departamento de Geografia, Universidade de São Paulo) 
Sarmiento, G.; \& Monasterio M. 1971. Ecología de las sabanas de America Tropical. Analisis macroecológico de los llanos de Calabozo, Venezuela. Cuadernos Geográficos nº 4. 126 p.

Schaeffer, D.A.; \& Witford, W.G. 1981. Nutrient cycling by the subterranean termite Gnathamitermes tubiformas in a Chihuahuan desert ecosystem. Oecologia 48: 277-83.

Scheffer, B.B. 1958. Do fossorial rodents originate Mima-type microrelief? American Midland Natulist 59: 505-10.

Schneider, M. D. \& Silva, D. B. 1997. Estrutura pedológica e dinâmica hidráulica de um "covoal" do córrego Fortaleza. Sociedade e Natureza, Ano $3, \mathrm{n} 5, \mathrm{p} 75-89$.

Scott , R.M. 1963. The soils of the Nairobi-Thika-Yatta-Machakos area. Nairobi, Department of Agriculture. $60 \mathrm{p}$.

Secretaria do Estado de Planejamento e Coordenação Geral - Seplan. 2000 Zoneamento Sócio-Econômico-Ecológico, Relatório técnico consolidado de Clima para o Estado de Mato Grosso. Parte 2: Sistematização das Informações Temáticas, nível compilatório, DSEE-CL-RT-002, Cuiabá, 68 p.

Sette, D. M. 2000. O holorritmo e as interações trópico-extratópico na gênese do clima e as paisagens do Mato Grosso. Dep. Geografia, FFLCH, USP, tese de doutorado, $394 \mathrm{p}$.

Soyer, J. 1983. Microrelief de butter basses sur les sols inondés saisonnièrment au Sud-Shaba (Zaïre). Catena, 10, 253-265.

Shuttleworth, W.J., Gash, J.H.C., Lloyd, C.R., Moore, C.J. and Roberts, J. 1985. Daily variations of temperature and humidity within and above Amazonian Forest, Weather, 40: 102-108. 
Shuttleworth, W.J., Gash, J.H.C., Lloyd, C.R., Moore, C.J., Roberts, J., Marques, A., Fish, G., Silva, V., Nazare, M. Molion, L.C.B., Abreu The. L., Nobleman, C.A., Cabral, M.R., Patel,S.R. and Carvalho, J., 1984. Eddy correlation measurements of energy partition in the Amazonian Forest, Quart. J.R. Meteorol. Soc., 110: 1143-1162.

Tarifa, J. R. 1994. Alterações climáticas resultantes da ocupação agrícola no Brasil, Revista do Depto de Geografia da FFLCHUSP, $\mathrm{n}^{\circ} 8$, ISSN 0102-4582, pág. 15-26.

Tarifa, J. R. 1996. Unidades Climáticas do Estado de Mato Grosso (1 ${ }^{\mathrm{a}}$ aproximação), Laboratório de Climatologia e Biogeografia, Departamento de Geografia da FFLCH, USP (inédito)

Tarifa, J. R. 1998. Cadernos de Climatologia. In: Diagnóstico SócioEconômico-Ecológico do Estado de Mato Grosso, Secretaria de Planejamento do Estado de Mato Grosso, SEPLAN, Cuiabá, MT

Tomé Jr, J.B. 1997. Manual para interpretação da análise do solo. Editora Agropecuária Ltda, 247 pp.

Trapnell, C.G.; Friend, M.T.; Chamberlain, G.T. \& Birch, H.F. 1976. The effects of fire and termites on a Zambian woodland soils. Journal of Ecology 64: 577-88.

Tröl, C. 1936. Termitensavannen. In: Louis, H. \& Panzer, W., eds. Landerkundliche Forschung Festschrift für Norbert Krebs. Stuttgart, J. Engelhorns Nachf., p. 275-313 
Vizier, J.F. 1983. Étude des phenomènes d'hidromorphie dans les sols des régions tropicales a saisons contrastées. ORSTOM, Paris, Série Travaux et Documents, 165, $294 \mathrm{p}$.

Wheeler, W.M. 1936. Ecological relationships of Ponerinae and otherants to termites. Proceedings of the American Academy of Arts and Sciences 71: 159-243.

Wright, I.R., Gash, J.H.C., Rocha, H.R. of the, Shuttleworth, W. J., Nobleman, C.A., Maitelli, G.T., Zamparoni, C.A.G.P. and Carvalho, P.R.A., 1992. Dry season micrometeorology Central of Amazonian Ranchland, Quartely Journal Royal Meteorological Society, 118: 10831099. 


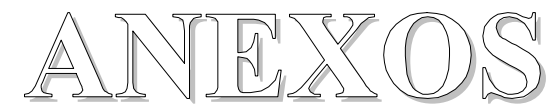

ANEXO 1: Sondagens

ANEXO 2: Entrevista com os proprietários da Fazenda São Fidel 


\section{Topossequência A}

\section{Sondagem n. 1 (S1) - Beira da Lagoa}

0-10 cm: Cor cinza escuro (5Y 4/1), textura argilosa, saturado, fragmentos milimétricos de carvão alterado, esparso.

10-20 cm: Cores cinza rosado (7,5YR 7/2) e cinza (7,5YR 6/1), argiloso, homogêneo.

0-30 cm: Matriz branco rosado (7,5 YR 8/2) com algumas manchas amarelo avermelhadas $(7,5 \mathrm{YR} 7 / 6$, argiloso, saturado.

30-40 cm: Idem, NA suspenso.

$60 \mathrm{~cm}$ : Cor cinza rosado $(7,5 \mathrm{YR} 7 / 2)$, aparecimento abrupto de areia média.

$70 \mathrm{~cm}$ : Cor branca $(7,5 \mathrm{YR} 8 / 1)$, areia branca com areia média e silte, diminui bastante a água, material branco seco, argilo-siltoso.

$90 \mathrm{~cm}$ : Idem, argilo-siltoso, seco.

$105 \mathrm{~cm}$ : Idem.

$120 \mathrm{~cm}$ : $\quad$ Cor branca $(7,5$ YR 8/1), idem.

$153 \mathrm{~cm}$ : Idem.

$180 \mathrm{~cm}$ : $\quad$ Idem, aparecem manchas de cor amarelo avermelhado (7,5YR 6/8).

$193 \mathrm{~cm}$ : Nível d'água.

$215 \mathrm{~cm}$ : Idem.

$250 \mathrm{~cm}$ : Idem.

$315 \mathrm{~cm}$ : Idem, manchas avermelhadas milimétricas, argilo-siltoso, pontuações amareladas que aumentam em profundidade. Na ponta do trado a matriz branca (10YR 8/1), passa para amarelo (10YR 7/6), que passa para vermelho amarelado (5YR 5/6), zonas amareladas e avermelhadas centimétricas.

$350 \mathrm{~cm}$ : Idem, diminuem as manchas e a matriz cinza clara esbranquiçada é amplamente dominante. Idem o restante.

$405 \mathrm{~cm}$ : Idem, diminui muito as manchas amarelas, só a matriz branca (10YR 8/2) permanece.

$425 \mathrm{~cm}$ : Idem, presença de fragmento arredondado de argila compacta com grãos de areia.

$435 \mathrm{~cm}$ : Idem, sem fragmentos sinais de manchas amareladas finas esparsas como antes, milimétricas.

$470 \mathrm{~cm}$ : Aumentaram as manchas em quantidade e aparentemente em dimensão, embora pareçam pequenas (milimétricas a subcentimétricas).

$490 \mathrm{~cm}$ : $\quad$ Idem, mas a textura parece ter bastante areia muito fina.

$510 \mathrm{~cm}$ : Idem, mas as manchas desaparecem e ficou só a matriz branca rosada novamente (10YR 8/2) com bastante areia muito fina.

$550 \mathrm{~cm}$ : Às vezes aparecem algumas manchinhas amareladas que desaparecem em seguida e reaparecem.

$570 \mathrm{~cm}$ : Fragmentos centimétricos a subcentimétricos arredondados começam a aparecer.

$600 \mathrm{~cm}$ : Idem. 


\section{Sondagem n. 2 (S2) - 12 metros à montante de S1}

0-10 cm: Serrapilheira de raízes da gramínea $(\mathrm{O} 1)$.

10-40 cm: Cor preta $(2,5 \mathrm{Y} 2 / 2)$, húmus, poucos restos de raízes, um pouco mais preto.

40-63 cm: idem, um pouco mais cinza, clareando em profundidade para a cor cinza muito escuro(2,5YR 3/1).

63-100 cm: Cor cinza escuro(10 YR 4/1), argiloso, homogêneo (transição).

$100 \mathrm{~cm}$ : Cor cinza rosado(7,5YR 6/2), argiloso com volumes bruno avermelhados (5YR 4,/3 e 4/4) difusos sem diferença de textura.

$125 \mathrm{~cm}$ : Cor bruno pálido (10YR 6/3), areia média molhada, $10 \mathrm{~cm}$ de areia.

$135 \mathrm{~cm}$ : Desaparece a areia e aparece a matriz argilosa branca seca (10YR $8 / 1)$.

$140 \mathrm{~cm}$ : Nível d'água.

$145 \mathrm{~cm}$ : Idem na mesma matriz.

\section{Sondagem n. $3(\mathrm{S3})$ - a 30 metros à montante de S2 entre dois murundus}

0-10 cm: $\quad$ Liteira, cor cinza muito escuro (10YR 3/1).

10-25 cm: Desbotado de matéria orgânica, cinza (10YR 5/1), com manchas cinza. muito escuro (10YR 3/1) e bruno pálido (10YR 6/3).

25-45 cm: Matriz argilosa, cor bruna (10YR 5/3).

$45 \mathrm{~cm}$ : Idem.

$55 \mathrm{~cm}$ : Idem.

$72 \mathrm{~cm}$ : $\quad$ Argila saturada, cor cinza claro brunado (10YR 6/2).

$90 \mathrm{~cm}$ : $\quad$ Cor cinza claro, (10YR 7/1) argiloso, homogêneo.

$100 \mathrm{~cm}$ : $\quad$ Cor branca (5YR 8/1), argiloso.

$132 \mathrm{~cm}$ : Idem.

$162 \mathrm{~cm}$ : $\quad$ O material fica mais seco.

$200 \mathrm{~cm}$ : Nível d'água.

$222 \mathrm{~cm}$ : $\quad$ Base do nível d'água, o material continua o mesmo.

\section{Sondagem n. 4 (S4) - Ao lado da TRA1 para comparar com ela}

0-2 cm: $\quad$ Serrapilheira, mas muito menor que as anteriores.

2-10 cm: Cor cinza muito escuro (10YR 3/1), orgânico.

10-20 cm: Cor bruna (10YR 5/3), argiloso, homogêneo.

$20 \mathrm{~cm}$ : Matriz de cor bruno claro amarelado (10YR 6/4), com pequenos nódulos vermelhos em (10R 4/8), ligeiramente duros, arredondados; argiloso com pequenas evidências difusas de hidromorfia.

$40 \mathrm{~cm}$ : Idem com mais volumes vermelhos, mas mais difusos e moles; volume mais úmido.

$50 \mathrm{~cm}$ : Idem, mas a matriz está mais argilosa, mais pegajosa e os nódulos são maiores, mais densos e mais numerosos.

$80 \mathrm{~cm}$ : Diminui os nódulos vermelhos duros dispersos na matriz muito argilosa e pegajosa de cor bruno muito pálido (10YR 7/4). 
$90 \mathrm{~cm}$ : $\quad$ Matriz cor bruno muito pálido (10YR 8/3) domina, nódulos são menos comuns e bem menores (milimétricos)

$100 \mathrm{~cm}$ : $\quad$ Matriz fica mais clara, adquirindo a cor branca (10YR 8/1), com raras zonas mais difusas amareladas,. base do lençol suspenso.

$102 \mathrm{~cm}$ : Idem.

$110 \mathrm{~cm}$ : $\quad$ Cor branca $(2,5 \mathrm{Y} \mathrm{8/1)}$, seco.

$132 \mathrm{~cm}$ : Idem, cor branca, homogêneo presença de nódulos da cor da matriz mais duros.

$150 \mathrm{~cm}$ : Idem, mas aparecem manchas amareladas e rosadas, sensação de cascalho miúdo de nódulos, como os anteriores (litorreliquiais), alguns maiores, centimétricos, água livre.

$160 \mathrm{~cm}$ : Manchas amareladas freqüentes e maiores, e bruno claro rosado (5YR 6/3) mais abundantes, matriz semelhante a anterior, fragmentos idem.

$172 \mathrm{~cm}$ : Idem, manchas avermelhadas aumentam em número, são pequenas;

$187 \mathrm{~cm}$ : $\quad$ Água subiu para 136.

\section{Sondagem n. ${ }^{\circ} 5$ (S5) - 120 metros da S4}

0-1 cm: Serrapilheira.

$1 \mathrm{~cm}$ : $\quad$ Cor vermelho acinzentado (2,5YR 5/2), argilo-arenoso seco.

$20 \mathrm{~cm}$ : $\quad$ Cor cinza $(2,5 \mathrm{Y} 6 / 0)$ a cinza brunado claro $(2,5 \mathrm{Y} 6 / 2)$, com zonas brancas (2,5YR 8/2) difusas e alongadas; argiloso, muito plástico.

$30 \mathrm{~cm}$ : Nódulos vermelhos (10R 5/8)como na sondagem anterior (vermelhos duros, arredondados ou subangulares, subcentimétricos, esparsos.

$42 \mathrm{~cm}$ : Aquela matriz muito argilosa, cinza claro (10YR 7/2), saturada, diminui notavelmente os nódulos.

$95 \mathrm{~cm}$ : $\quad$ Idem.

$100 \mathrm{~cm}$ : Idem, mas ficou branca $(2,5 \mathrm{Y}$ 8/1) e está mais seco (base do suspenso).

$180 \mathrm{~cm}: \quad$ Idem.

$200 \mathrm{~cm}$ : $\quad$ Manchas amareladas, nível d'água subiu a $160 \mathrm{~cm}$.

\section{Sondagem n. 6 (S6) - 120 metros de S5}

0-1 cm: Película orgânica ressecada com raízes embaixo.

1-10 cm: Cor cinza claro(10YR 6/1), argilo-arenoso com algumas manchas mais escuras de cor cinza (10YR 5/1) pouco contrastadas.

10-25 cm: Idem, mas fica argiloso e as zonas mais escuras parece aumentar, alguns pontos vermelhos.

$50 \mathrm{~cm}$ : $\quad$ Cor bruno pálido (10YR 6/3) muito argiloso com nódulos vermelhos milimétricos duros nítidos.

68cm: $\quad$ Cor bruno muito pálido (10YR 8/3) muito argiloso, idem, muito úmida.

$100 \mathrm{~cm}$ : Idem, mas sumiram os nódulos vermelhos muito úmidos.

$130 \mathrm{~cm}$ : $\quad$ Idem, mas começou a ficar menos úmido.

$145 \mathrm{~cm}$ : Novamente reaparecem os nódulos, poucos.

$158 \mathrm{~cm}$ : Presença de colunas avermelhadas difusas. 
$163 \mathrm{~cm}$ : Subida do nível d'água.

$168 \mathrm{~cm}$ : Água livre.

$200 \mathrm{~cm}$ : Material seco argiloso, esbranquiçado, sem zonas vermelhas (base do freático). 


\section{Sondagem n. 7 (S7) - 120 metros acima da S6, sobre um murundu.}

0-1 cm: Cor cinza escuro (10YR 3/1), seco, muita raiz fina, agregados arredondados que se aderem facilmente na mão.

3-20 cm: Cor bruno escuro acinzentado (10YR 4/2), textura argilosa.

$25 \mathrm{~cm}$ : Cor bruno amarelado (10YR 5/4), textura argilosa.

$35 \mathrm{~cm}$ : Cor bruno amarelado (10YR 5/4) na matriz dominante, com volumes bruno escuro amarelados (5YR 4/6), concreções ferruginosas desfeitas na tradagem.

$50 \mathrm{~cm}$ : Idem, com aumento de concreções (maior dificuldade de penetração do trado), nas paredes do trado notas-se vestígios de microagregação.

$60 \mathrm{~cm}$ : Idem, com muitos volumes de concreções macias, de coloração vermelha $(2,5 \mathrm{YR} 4 / 6)$ aumento de umidade e penetração do trado mais facilitada.

$65 \mathrm{~cm}$ : Cor pouco mais clara, bruno amarelado (10YR 5/4), diminui as concreções e aumenta a umidade, mesma textura argilosa.

$90 \mathrm{~cm}$ : $\quad$ Cor bruno amarelado claro (10YR 6/4), volta a parecer muitas concreções macias de cor vermelha $(2,5 \mathrm{YR} 4 / 6)$, continua muito úmido e grudento no trado.

$100 \mathrm{~cm}$ : $\quad$ Cor cinza claro (10YR 7/2), muito macia a penetração, muito úmida e contínua com concreções moles de cor vermelha.

$105 \mathrm{~cm}$ : Cor bruno muito pálido (10YR 8/3) (mais claro), diminui as concreções, continua muito úmido, menos grudento e aparece mancha de cor rosa na ponta do trado.

$120 \mathrm{~cm}$ : Idem, pouco mais claro.

$140 \mathrm{~cm}$ : Idem, com manchas rosadas, desaparecem as concreções, muito pegajoso.

$145 \mathrm{~cm}$ : Cor branca (10YR 8/1), desaparecem as concreções e também as manchas rosadas.

$200 \mathrm{~cm}$ : Menos úmido com grânulos.

$205 \mathrm{~cm}$ : Menos úmido (quase seco), com grânulos e manchas rosadas.

$220 \mathrm{~cm}$ : Slup, idem seco, com maior dificuldade se penetração, água livre na ponta do trado.

$245 \mathrm{~cm}$ : Idem, material seco, nível d'água medido com $200 \mathrm{~cm}$, portanto rapidamente sobe $20 \mathrm{~cm}$.

Sondagem n. 8 - (S8) - 120 metros acima da S7

0-5 cm: Presença de areia lavada com raízes finas, argilo-arenoso.

$20 \mathrm{~cm}$ : Cor bruno acinzentado (10YR 5/2), argiloso com dificuldade de penetração.

$25 \mathrm{~cm}$ : Idem, com presença de alguns volumes de concreções moles vermelhas;

$40 \mathrm{~cm}$ : $\quad$ Cor cinza claro brunado (10YR 6/2), mais claro e mais úmido, continua com dificuldade de penetração, com raras concreções moles.

$50 \mathrm{~cm}$ : $\quad$ Cor cinza claro brunado(10YR 6/2), fácil penetração, muito úmido e pegajoso, com raras concreções. 
$70 \mathrm{~cm}$ : Idem, com muitas concreções moles e vermelhas (2,5YR 4/6), muito úmido (saturado) e fácil penetração.

$75 \mathrm{~cm}$ : Idem, com aumento de concreções vermelhas.

$100 \mathrm{~cm}$ : Idem, com menos concreções, menos úmido na ponta do trado.

$120 \mathrm{~cm}$ : Continua argiloso, praticamente desaparecem as concreções, cor cinza rosado $(7,5 \mathrm{YR} 7 / 2)$, com manchas rosadas, material quase seco.

$130 \mathrm{~cm}$ : Idem, com desaparecimento de concreções.

$140 \mathrm{~cm}$ : $\quad$ Água livre na ponta do trado, idem.

$160 \mathrm{~cm}$ : Slup, idem, saturado em água, água na ponta do trado, atinge o nível d'água, sobe em seguida para $145 \mathrm{~cm}$.

\section{Sondagem n. 9 (S9) - 300 metros acima de S8}

$20 \mathrm{~cm}$ : $\quad$ Textura argilo-arenosa, cor cinza escuro (10YR 4/1).

$25 \mathrm{~cm}$ : Textura argilosa, cor bruno escuro (7,5YR 4/2).

$40 \mathrm{~cm}$ : $\quad$ Idem desde o início, dificuldade de penetração.

$50 \mathrm{~cm}$ : $\quad$ Mais úmido, mais claro com algumas concreções, cor bruna (10YR $5 / 3$ ), dificuldade de penetração.

$65 \mathrm{~cm}$ : $\quad$ Muito úmido, idem.

$70 \mathrm{~cm}$ : $\quad$ Surgimento de muitas concreções moles e vermelhas, matriz cinza rosado (10YR 6/2).

$84 \mathrm{~cm}$ : Idem, com muitas concreções de cor vermelha, mesma proporção da matriz argilosa clara.

$100 \mathrm{~cm}$ : $\quad$ Idem, com domínio de concreções em relação à matriz.

$115 \mathrm{~cm}$ : com diminuição de concreções.

$130 \mathrm{~cm}$ : Desaparecimento de concreções, cor branco rosado (10YR 8/2), material quase seco.

$140 \mathrm{~cm}$ : Idem.

$165 \mathrm{~cm}$ : Àgua livre na ponta do trado, com retorno das concreções.

$180 \mathrm{~cm}$ : Slup, domínio de concreções, surgimento do nível d'água com 150 $\mathrm{cm}$.

$200 \mathrm{~cm}$ : Diminui as concreções e o material fica seco.

Sondagem n. 10 (S10) - 120 metros acima da S9. Neste local aumenta muito a densidade de murundus, porém mais baixos em relação aos anteriores, mais à jusante, e parece que a superfície do terreno tende a coincidir com a superfície dos murundus.

$20 \mathrm{~cm}$ : $\quad$ Cor bruno escuro (10YR 4/2), argilo-arenoso.

$25 \mathrm{~cm}$ : Início de algumas concreções milimétricas de óxido de ferro, cor cinza rosado dominante (10YR 6/2), mais clara que a anterior, de textura argilosa muito pegajosa.

$32 \mathrm{~cm}$ : Ocorrência comum de concreções milimétricas moles, cor e textura idem, e formação de microagregados.

$50 \mathrm{~cm}$ : Aumenta a umidade, continua as concreções, a cor mais dominante é bruno claro (10YR 6/4). 
$60 \mathrm{~cm}$ : Muito úmido, aumenta as concreções, matriz idem, com penetração do trado mais facilitada.

$80 \mathrm{~cm}$ : $\quad$ A quantidade de concreção é igual a da matriz.

$90 \mathrm{~cm}$ : Mais seco com domínio de coloração vermelha (2,5YR 5/6), mas continua matriz igual a anterior, as concreções desapareceram.

$105 \mathrm{~cm}$ : Volta a aparecer muitas concreções de cor rosa com matriz cinza e seca.

$115 \mathrm{~cm}$ : Aumento de concreções que passa a dominar, com maior dificuldade de penetração. As concreções são moles, se desmancham no trado e tem a cor vermelha $(2,5 \mathrm{YR} 4 / 8)$.

$135 \mathrm{~cm}$ : Diminui as concreções, continua relativamente seco.

$145 \mathrm{~cm}$ : Praticamente desaparece as concreções. A matriz argilosa tem coloração amarela (10YR 7/6).

$150 \mathrm{~cm}$ : Volta a aparecer poucas concreções, com a mesma matriz praticamente seca.

$165 \mathrm{~cm}$ : Concreções duras centimétricas e milimétricas arredondadas e irregulares. A partir dessa profundidade a cor dominante é amarela (10YR 7/6) com volumes vermelhos das concreções.

$190 \mathrm{~cm}$ : Água livre na ponta do trado e domínio de concreções.

$222 \mathrm{~cm}$ : Slup, o nível d'água subiu $23 \mathrm{~cm}$ rapidamente, portanto, $219 \mathrm{~cm}$.

A distância de S10 e o início da área desmatada é de 144 metros.

\section{Topossequência B}

\section{Sondagem n. 11 (S11) - $100 \mathrm{~m}$ acima da TRB6}

0-5 cm: Cor bruno escuro acinzentado (10YR 4/2), textura argilo-pouco arenosa.

$20 \mathrm{~cm}$ : $\quad$ Cor bruno escuro (7,5YR 4/4), textura argilosa.

$25 \mathrm{~cm}$ : Idem.

$30 \mathrm{~cm}$ : $\quad$ Cor bruno forte $(7,5 \mathrm{YR} 4 / 6)$, textura argilosa.

$40 \mathrm{~cm}: \quad$ Idem

$50 \mathrm{~cm}$ : Idem.

$60 \mathrm{~cm}$ : $\quad$ Cor bruno forte (7,5YR 5/8), idem.

$80 \mathrm{~cm}$ : Idem.

$90 \mathrm{~cm}$ : Idem.

$100 \mathrm{~cm}$ : Idem

$110 \mathrm{~cm}$ : Idem.

$135 \mathrm{~cm}$ : Idem, com poucas concreções milimétricas.

$150 \mathrm{~cm}$ : Idem, aumentando a quantidade de concreções e de plintita.

$160 \mathrm{~cm}$ : $\quad$ Cor bruno forte $(7,5 \mathrm{YR} 5 / 8)$, pouco mais claro que o anterior, além da plintita e concreções aparece também volumes de argila de tamanho centimétrico a milimétrico, volumes de até $0,5 \mathrm{~cm}$ com coloração vermelho amarelado (5YR 5/6).

$180 \mathrm{~cm}$ : $\quad$ Cor amarelo avermelhado (7,5YR 6/8), restante idem ao anterior.

$195 \mathrm{~cm}$ : $\quad$ Idem, muito úmido, pegajoso na ponta do trado.

$220 \mathrm{~cm}$ : Idem, desaparecem as concreções, presença de nódulos de argila. 
$250 \mathrm{~cm}$ : Cor vermelha $(2,5 \mathrm{YR} 5 / 8)$, úmido, textura argilosa, consistência pegajosa.

$280 \mathrm{~cm}$ : Idem.

$290 \mathrm{~cm}$ : Idem.

$300 \mathrm{~cm}$ : Idem.

\section{Sondagem n. ${ }^{\circ} 12$ (S12) - Dentro da TRB6}

$165 \mathrm{~cm}$ : Cor bruno forte $(7,5 \mathrm{YR} 5 / 6)$ e nódulos de plintita e concreções vermelho amarelado (5YR 4/6).

$195 \mathrm{~cm}$ : Cor bruno forte $(7,5 \mathrm{YR} 5 / 6)$, textura argilosa.

$205 \mathrm{~cm}$ : Cor bruno forte $(7,5$ YR 5/6), desaparecem os nódulos.

$230 \mathrm{~cm}$ : $\quad$ Cor vermelho amarelo (5YR 5/8), voltam a aparecer os nódulos de plintita e concreções.

$240 \mathrm{~cm}$ : idem, nódulos e concreções de cor vermelha $(2,5 \mathrm{YR} 4 / 6)$

$255 \mathrm{~cm}$ : Cor vermelha $(2,5 \mathrm{YR} 5 / 8)$, desaparecem as concreções.

$285 \mathrm{~cm}$ : Idem

$315 \mathrm{~cm}$ : Idem.

$365 \mathrm{~cm}$ : Idem.

$465 \mathrm{~cm}$ : Idem, surgem manchas claras de cor vermelho amarelado $(7,5 \mathrm{YR}$ $6 / 6)$.

$555 \mathrm{~cm}$ : Idem, sem mudanças desde 4,65 m.

\section{Sondagem n. ${ }^{\circ} 13$ (S13) - $310 \mathrm{~m}$ abaixo da TRB6}

0-5 cm: Cor bruno escuro amarelado (10YR 3/4), argilo-pouco arenoso.

$20 \mathrm{~cm}$ : $\quad$ Cor bruno amarelado escuro (10YR 4/4), textura argilosa.

$30 \mathrm{~cm}$ : $\quad$ Idem, cor bruno amarelado escuro (10YR 4/6).

$45 \mathrm{~cm}$ : $\quad$ Idem, cor bruno forte $(7,5 \mathrm{YR} 4 / 6)$.

$75 \mathrm{~cm}$ : $\quad$ Idem, cor bruno forte $(7,5 \mathrm{YR} 5 / 8)$.

$130 \mathrm{~cm}$ : $\quad$ Idem, com poucos volumes de plintita.

$150 \mathrm{~cm}$ : Cor $7,5 \mathrm{YR} 5 / 8$, aumenta a quantidade de plintita

$190 \mathrm{~cm}$ : $\quad$ Cor bruno forte (7,5YR 5/8), com volumes de plintita

$230 \mathrm{~cm}$ : desaparecem as plintitas.

$250 \mathrm{~cm}$ : Cor vermelha $(2,5 \mathrm{YR} 4 / 8)$

$290 \mathrm{~cm}$ : Idem.

A sondagem terminou nessa profundidade $(2,20 \mathrm{~m})$, nessa cor $(2,5 \mathrm{YR} 4 / 8)$ vermelha. Analisando a tradagem, percebe-se a similaridade com a trincheira TRB6.

\section{Sondagem n. ${ }^{\circ} 14$ (S14) - 105 m acima da TRB6}

0-15 cm: Cor bruno escuro (10YR 3/3), textura argilo-pouco arenosa.

$20 \mathrm{~cm}$ : $\quad$ Cor bruno escuro amarelado (10YR 4/4) textura argilosa.

$45 \mathrm{~cm}$ : $\quad$ Cor bruno forte $(7,5 \mathrm{YR})$.

$90 \mathrm{~cm}$ : $\quad$ Cor bruno forte (7,5YR 5/8), aparecimento de pouca plintita, a cor fica mais forte. 
$130 \mathrm{~cm}$ : Cor bruno forte (7,5YR 5/8), aumenta a plintita. Observa-se que nesta tradagem, bem como nas anteriores, que nesta camada com muita plintita, o solo fica mais molhado e mais grudento.

$230 \mathrm{~cm}$ : $\quad$ Cor vermelho amarelado (5YR 5/8), desaparece a plintita, o solo fica mais seco, diminui a pegajosidade.

$250 \mathrm{~cm}$ : $\quad$ Cor vermelha $(2,5 \mathrm{YR} 4 / 8)$, mesmo material mais vermelho até o final, ou seja, aparecer as manchas mais claras.

$300 \mathrm{~cm}$ : Idem, começa a aparecer as manchas mais claras. São raros os pontos de argila mais clara.

\section{Sondagem n. 15 (S15) - Dentro da TRB5}

$170 \mathrm{~cm}$ : $\quad$ Matriz (50\%) amarelo brunado (10YR 6/6) e (50\%) de plintita vermelha (2,5YR 4/8).

$260 \mathrm{~cm}$ : Desaparece a plintita, aparece o material mistura do vermelho (2,5YR $4 / 8$ ) que predomina sobre o bruno amarelado (10YR 5/8), muito pegajoso e muito úmido.

$330 \mathrm{~cm}$ : Material mais homogêneo, menos úmido, cor vermelho amarelo (5YR 5/8).

$360 \mathrm{~cm}$ : $\quad$ Cor vermelha $(2,5 \mathrm{YR} 4 / 8)$, material mais seco.

$440 \mathrm{~cm}$ : Nível freático, surgem as manchas claras, cor bruno muito pálido (10YR7/4) em matriz vermelha $(2,5 \mathrm{YR} 4 / 8)$.

\section{Sondagem n. ${ }^{\circ} 16(\mathrm{~S} 16)$ - $120 \mathrm{~m}$ abaixo da TRB5}

0-20 cm: $\quad$ Cor bruno escuro amarelado (10YR 4/6).

$30 \mathrm{~cm}$ : $\quad$ Cor bruno amarelado (10YR 5/6).

$50 \mathrm{~cm}$ : Cor bruno amarelado ( $10 \mathrm{YR} 5 / 8$ ), aparecimento de plintita comum.

$110 \mathrm{~cm}$ : $\quad$ Cor bruno amarelado (10YR 5/6), aumento considerável de plintita, pegajoso, úmido.

$170 \mathrm{~cm}$ : Cor amarelo avermelhado (7,5YR 6/6), muita plintita, pegajoso, úmido, passando para vermelho amarelado (5YR 5/8) com muita plintita na mesma camada.

$210 \mathrm{~cm}$ : $\quad$ Cor vermelho amarelado (5YR 5/8), diminuindo a plintita, mais seco.

$230 \mathrm{~cm}$ : Cor vermelho amarelado (5YR 5/8), cor homogênea, mais seco, sem plintita.

2,60 cm: $\quad$ Cor vermelho amarelado (5YR 5/8).

$270 \mathrm{~cm}$ : Cor vermelho amarelado (5YR 5/8) (matriz), com manchas 2,5YR $5 / 8$, mais úmido.

\section{Sondagem n. ${ }^{\circ} 17$ (S17) - dentro da TRB4}

$170 \mathrm{~cm}$ : Cor vermelho amarelado (7,5YR 6/6) com plintita, muito úmido, pegajoso.

$210 \mathrm{~cm}$ : $\quad$ Cor vermelho amarelado (7,5YR 6/6), com plintita, mais úmido, pegajoso.

$340 \mathrm{~cm}$ : $\quad$ Cor vermelho (2,5 YR 5/8), sem plintita, nível d'água aos $320 \mathrm{~cm}$. 
Ao romper a camada de plintita o nível d'água subiu mais rápido.

Sondagem n. ${ }^{\circ} 18$ - dentro da TRB3

$160 \mathrm{~cm}$ : Cor bruno pálido (10YR 6/3) na matriz e vermelho na plintita (2,5YR 4/8).

$195 \mathrm{~cm}$ : Idem, bem molhado.

$220 \mathrm{~cm}$ : Inicia material vermelho (2,5YR 4/8), nível d'água.

$250 \mathrm{~cm}$ : Final da tradagem.

\section{Sondagem n..$^{\circ} 19$ (S19) - 90 m adiante da TRB3}

0-5 cm: $\quad$ Cor bruno escuro (10YR 3/3), argilo-pouco arenoso

$20 \mathrm{~cm}$ : Horizonte novo, não visto anteriormente, cor cinza claro brunado (10YR 6/2), argiloso, com plintita vermelha.

$60 \mathrm{~cm}$ : Idem, com muita plintita.

$70 \mathrm{~cm}$ : Idem.

$85 \mathrm{~cm}$ : Idem.

$100 \mathrm{~cm}$ : $\quad$ Cor cinza claro (10YR 7/2), desaparece a plintita.

$120 \mathrm{~cm}$ : Cor amarelo avermelhado (5YR 6/8), mistura de matriz com plintita. Amostra seca com plintita, todas as anteriores estavam secas.

$180 \mathrm{~cm}: \quad$ Cor cinza claro $(10 \mathrm{YR} 7 / 2)$ na matriz e vermelha $(2,5 \mathrm{YR} 4 / 8)$ na plintita.

$200 \mathrm{~cm}$ : $\quad$ Cor bruno muito pálido (10YR 7/3), desaparece a plintita, nível freático subindo rapidamente $40 \mathrm{~cm}$, sugerindo desconfinamento.

36 metros abaixo da TRB3 ocorre quebra de declividade de $30 \mathrm{~cm}$, iniciando o terço inferior da vertente.

Sondagem n. ${ }^{\circ} 20$ (S20) - $30 \mathrm{~m}$ abaixo da TRB3.

$5 \mathrm{~cm}$ : Cor bruno muito escura acinzentado (10YR 3/2), argila pouco arenosa

$20 \mathrm{~cm}$ : $\quad$ Cor bruno acinzentado (10YR 5/2), argilosa.

$25 \mathrm{~cm}$ : $\quad$ Novo material cor bruno claro amarelado (10YR 6/4) com plintita.

$35 \mathrm{~cm}$ : $\quad$ Idem, muito úmido, grudento, pegajoso, com muita plintita.

$110 \mathrm{~cm}$ : Aumenta a quantidade de plintita, mais seco, cor mais rosada, bruno pálido (10YR 6/3) e cor vermelha (2,5YR 5/8) da plintita.

$150 \mathrm{~cm}$ : $\quad$ Cor vermelho amarelado (5YR 6/6), mistura de matriz com plintita.

$230 \mathrm{~cm}$ : Cor vermelho amarelado $(7,5$ 6/6), a plintita diminui consideravelmente, amostra muito molhada.

$240 \mathrm{~cm}$ : Água. O nível d'água subiu $30 \mathrm{~cm}$ após penetrar esta camada.

Sondagem n. 21 (S21) - Dentro da TRB2 
$170 \mathrm{~cm}$ : $\quad$ Cor bruno pálido (10YR 6/3) com muita plintita

$190 \mathrm{~cm}$ : Amostra seca, cor rosada, ou seja, amar3elo avermelhado (5YR 6/6) mistura de matriz mais plintita.

$220 \mathrm{~cm}$ : Idem.

$235 \mathrm{~cm}$ : Água, mesmo material.

$245 \mathrm{~cm}$ : Desaparece a plintita, cor cinza claro (10YR 7/2). A água sobe 30 $\mathrm{cm}$.

\section{Sondagem n. ${ }^{\circ} 22(\mathrm{~S} 22)-90 \mathrm{~m}$ abaixo de $\mathbf{P}_{13}$ e $P_{14}$}

0-10 cm: $\quad$ Cor cinza claro (10YR 4/1).

$30 \mathrm{~cm}$ : $\quad$ Cor cinza claro brunado (10YR 6/2).

$45 \mathrm{~cm}$ : Cor cinza claro brunado (10YR 6/2), água, nível d'água desconfinado não subiu.

$60 \mathrm{~cm}$ : $\quad$ Cor bruno acinzentado (10YR 5/2), seco.

$70 \mathrm{~cm}$ : $\quad$ Mesmo material, com plintita, seco.

Abaixo $70 \mathrm{~cm}$ : Material de aparência cinza mosqueado, cor amarelo avermelhado (5YR 6/6)

$170 \mathrm{~cm}$ : $\quad$ Cores variegadas, cinza (7,5YR 6/1), rosado (5YR 7/8) e vermelho (2,5YR 4/8), a plintita ultrapassa a camada confinante, a água sobe $75 \mathrm{~cm}$. O lençol inferior foi atingido aos $80 \mathrm{~cm}$, subiu $45 \mathrm{~cm}$.

Sondagem n. 23 (S23) - 17 metros abaixo da S22 - nível d'água aflorante.

$5 \mathrm{~cm}$ : $\quad$ Cor bruno acinzentado (10YR 5/2), argilo-arenoso.

$20 \mathrm{~cm}$ : $\quad$ Cor bruno acinzentado (10YR 5/2), argiloso, água.

$40 \mathrm{~cm}$ : $\quad$ Mesmo material, sem plintita.

$50 \mathrm{~cm}$ : $\quad$ Mesmo material com plintita, cor mais rosada.

110cm: Desaparece a plintita, material cinza com algumas manchas rosadas.

$120 \mathrm{~cm}$ : $\quad$ Cor cinza claro (10YR 7/2), material seco, quase sem plintita. Neste local ocorre o encontro do lençol suspenso com o inferior. 
Entrevista gravada na Fazenda São Fidel em 26/01/2000 com os senhores José Vilmar Knapik e João Knapik, proprietários da Fazenda.

- Onde os senhores nasceram?

- (Sr. José) Nasci em Pato Branco no Paraná, em 1957, estou com 43 anos. Vivi lá até os 23 anos e daí viemos pra Sorriso.

- (Sr. João) Eu também sou nascido em Pato Branco, Paraná, em 14 de fevereiro de 1960, viemos pra cá em 1980 e estamos vivendo aqui até hoje.

- Qual é o estado civil dos senhores?

- (Sr. João) Sou casado com a Sirlei, temos 2 filhos, um de 10, outro de 6 anos.

- (Sr. José) Sou casado com a Frida, temos 2 filhos, o Marcelo com 17 anos e a Marciele com 12 anos.

- De onde vieram?

- Eu vim direto de Pato Branco para cá, pra Primaverinha, que na época era município de Nobres ainda, hoje é município de Sorriso.

- que os levou a virem de lá de Pato Branco no Paraná, região sul do País, para esta região, centro-oeste do Brasil, já próximo a Amazônia?

- (Sr. José) Meu pai tinha um pinhal lá, dai vendeu, arrumou um dinheirinho e dai saímos pra aventurar, para conseguir alguma coisa diferente, algo mais Ne. Então, a primeira vez que o pai veio, ,em 1979, eu e ele, viemos até Sinop, daí ele comprou uma Fazenda no município de Vera, em dezembro de 1979, dai voltamos embora e por sinal naquela época até ele chegou a pegar uma malária em Sinop e ficou internado lá, e ai quando ele melhorou nós voltamos pra Pato Branco e em Março de 1980, voltamos eu, o meu pai e o João pra ver a terra de Vera lá, e naquela época dai vimos que era muita mata, tava meio difícil preparar pra plantar, viemos voltamos, compramos esta fazenda aqui que é a São Fidel, e já em seguida começamos a derrubar, a enleirar um pouco, era uma terra devoluta, então foi recolhida, então fomos abrindo aos poucos, o INCRA até indeferiu um pedaço e deferiu o outro, dai com o tempo o INCRA fez outra revisão, viu que nós tava trabalhando e voltou a dar total área documentada pra nós. Isso foi em março de 1980.

- Quando veio, o seu pai trouxe a família toda, ou apenas parte das familia?

- (João) Não, quando nós viemos, veio no começo o pai, eu e o Zé, aí voltou o pai e o Zé, ficamos eu e um peão aqui. Aí ficamos um tempo aqui ai ele voltou pro sul, casou, meu mano né, casou lá em Pato Branco daí retornou pra cá de novo. A mãe nunca veio pra cá, o pai sempre ele morou 2-3 anos aqui mas sempre sozinho, morou com nóis né. A mãe sempre morou lá, veio passear, conhecer e passear de vez em quando, com o tempo ele acabou voltando a viver em Pato Branco.

- Teve dificuldade para legalizar a terra junto ao INCRA? 
- (José) Olha, no começo a gente tinha um pouco de medo que o INCRA assustava e tal, o que nós queria fazer é abrir e trabalhar. Mas ai veio um segundo probleminha, em 80 nós plantamos arroz, foi o ano que eu casei dai eu fui pro Paraná e voltamos, o João ficou aí, e eu voltei casado em dezembro de 1980, quando voltei com a minha esposa, chegando, ela vinha pra conhecer aqui, não conhecia, o arroz tava tudo bonito, alto, foi em fevereiro de 1981, e a documentação tava em andamento, dai foi naqueles dias, nós queria começar a colher, desandou água. Foi aonde começou o nosso pequeno problema aqui, que nós não conseguia colher com a colhedeira e, dai a pouco, voltava a pé, ficava encalhado. Começou a inundar, chovia demais, começou a ficar bem precário pra nós. E quando o senhor pedia a documentação, foi feita 3-4 vistorias e dentro de uns 3 anos começou a ficar tudo legalizado. Hoje está escriturado em meu nome e no nome do meu irmão João.

- Chegando aqui, quais foram as dificuldades que encontraram para utilizar e manejar a terra?

- (José) Em primeiro lugar, a distância né, a falta de recursos, não tinha nada aqui. É... estrada muito ruim mesmo né, calcário na época longe, telefone não existia, banco, financiamento era dificil, muitas dificuldades, o adubo vinha do sul, semente vinha de fora, não tinha secador, comércio de produtos, dinheiro, pouco recurso né, muitas dificuldades.

- Com toda essa dificuldade, dava pra sobreviver, fechar o ano com lucro e alcançar coisas melhores no ano seguinte?

- (José) No começo não, não tava empatando, tava dando quase prejuizo no começo né, por motivo de tudo isso aí. Logo no terceiro ano em diante começou a melhorar, mas no começo ,mesmo o pai tava desanimado.

- Como conseguiram vencer estes anos dificeis?

- (João) A gente via né que era uma região muito plaina, terra boas, favorável pra trabalhar, a gente via futuro né, com todo prejuizo, com tudo, a gente tava vendo que de uma hora pra outra a coisa ia melhorar, né. Acreditamos e melhorou.

- Quando começou a melhorar?

- Quando entrou a soja. Quando entrou a soja né, passou a ter dois produtos né, arroz e soja, começou a diversificar e ai o arroz também alcançou um preço bom, a gente começou a acertar as variedades, né, um pouco mais, começou a produzir e dali pra cá nós temos....... Nós não tivemos problema porque nós sempre viemos de pouquinho né, abrindo um pouquinho um ano, um pouquinho o outro, então nós não tivemo mais problema.

- Isso em que ano foi?

- (João) Em 1984-85 começou a ficar melhor. 
- Com relação às características da terra, que tipo de problema encontraram?

- (João) Bão, quanto ao solo, nós sofremo até um pouquinho. No começo um dois problema foi que a gente não tinha muito conhecimento, inclusive, um exemplo, mesmo corrigir a terra com calcário, as análises pediam uma quantidade, e a gente colocava, colocava um pouquinho menos, veio a causar uns probleminhas, sabe que depois, mais tarde viemo a corrigir, a terra, por exemplo, a nossa terra aqui, ela é uma terra que com pouco calcário corrige sabe, e a gente corrigia conforme pedia a análise e tava dando problema com a soja, tava colocando em excesso. Hoje, ainda, se colocar o que a análise pede, quanto ao nosso terreno, ainda dá um pouquinho de problema.

- E porque o senhor acha que a análise pede mais do que o terreno necessita?

- (João) Eu não sei, eu não sei explicar isso aí, eu acho que... não tenho conhecimento porque isso acontece na região inteira. Se colocar o que pede, depois tem que corrigir com manganês. E quanto à terra, o problema sério que a gente tivemo, foi de encharcar a terra, né. Encharcar por exemplo, às vezes dá uma chuva muito pesada, um terreno plaino que nem o nosso, ele amolecê, não que inunde, ele amolece, então foi aonde nós começamo a drená. Um projeto tudo pra região que a Drenomat fez, drenamo e começô a tirar, não que seque o terreno, mas tirar... quando dá uma chuva pesada, em vez dela ficá um certo tempo no nível do solo pra penetrá, com o dreno, aquela água da chuva na hora ela praticamente ajuda a tirá, o dreno, né. Então, o solo dai como tem um valo aí de 1 metro e meio de fundura, o solo tá pronto pra receber outra chuva, quando cai naquela camada, cai e vai penetrá e se você não tiver dreno, ele cai e o solo não tá adequado pra recebê a chuva, inclusive, quando tocava arroz, essa umidade trazia muita doença na planta, né, muita doença, o calor do sol e a umidade, aí com esse dreno acabô o problema, não tivemo mais problema.

- Tem muito desse tipo de solo que encharca aqui na região?

- (José) Tem. Tá tendo aqui no Lucas, por sinal comentaram ontem dessas pequena chuva que deu aí, tem muito povo que não tem feito o projeto de envaletamento, tá dando problema de colhedeira atolada. Então, o que tá acontecendo que nós achamos que nem a Drenomat faz os projetos, ela tpa querendo escoá aquela água que fica na terra plana, então tem uma mesa, não tem saída, aquela água fica ali, com os pequeno valo que nem o João falô, a água vai escoando pros lugar mais baixo, né. Então nós não viu mais problema aqui, o Sr. Prudêncio tá acompanhando, tá vendo os valo, que tipo é, o valo enxuga essa área né, então, quem não tá tendo o projeto de envaletamento, com qualquer chuva nas terras úmidas, nas terras baixas no Chapadão vai ter problema.

- Essas terras são muito extensas aqui na região? 
- (José) Da região de Lucas até Sorriso, 15\%, estimadamente 15\%.

- Como é a ocorrência dessas áreas dentro da paisagem?

- (João) É área plana, não é topo, inclusive tem área de terra preta, terra mais amarelada, tem áreas de terra vermelha que é aqui, bem avermelhada, não tem um tipo de região nascente de água ou coisa assim, é onde é plano, que não é um atoleiro, não é um brejo, não é um banhado que a gente envaleta, né. É uma terra que simplesmente na hora da chuva pesada, naquela hora uma colhedeira dois das depois não sobe, e agora não atola mais.

- Pelo o que estou entendendo, não é o tipo de solo, a cor do solo que vai definir se a área vai ser encharcada ou não, é o relevo?

- (João) Planície. Tem terra branca, tem terra de tudo que é cor, quando for plana amolece.

- Que tipo de relevo predomina nessas áreas alagadiças?

- (João) Quanto mais argilosa, a terra é mais favorável a esse problema. A terra arenosa, que tem menos argila, ali não tem problema, e onde é a terra argilosa, no caso da nossa, é a terra que vem amolecer conforme a chuva e o calor do sol ela...

- Estou entendendo que são duas condições básicas: uma do relevo, que é o relevo plano, de planície, e a outra é o alto teor de argila do solo.

- (João) É... terra arenosa não acha dessas terra encharcada, em hipótese alguma. E outra coisa, está sendo descoberto, depois de estar fazendo esse projeto, que no começo os valo era feito mais perto um do outro, hoje está chegando à conclusão que não precisa esses valo estar muito perto, que é justamente pra tirar a água que está em cima do solo, embaixo não mexe com nada. Então os nossos valo hoje estão tudo a 300 metro de distância um do outro. Isso no começo a gente achava que tinha que ser pertinho, hoje a gente tá vendo que não.

- Antes de ter os valos, quando essas áreas encharcavam que tipo de problema vocês enfrentavam?

- (José) Pra trabalhar nela, não é? Era problema o seguinte: que não escoava, ficava a água em cima da terra, às vezes ficava uma camada de $10 \mathrm{~cm}$, a água não tinha para onde ir e o trator patinava e atolava, então qualquer laminada que o cê dava com o trator, que a água podia escoar, já dai há 2 dias já estava seco, simplesmente, ela parece que forma uma camada ou 2 pra baixo, uma compactação dessas terra e a água não infiltra pra baixo né, a água quer escoar, ela não quer ficar, não quer descer, ela fica ali, dai sem Ter pra onde ir.

- Dava pra plantar nessas áreas antes?

- (José) Plantava na época do começo da chuva e dali há pouco, quando dava 2-3 chuvão em novembro/dezembro, você ia lá, o soja tava $20 \mathrm{~cm}$ dentro da água.

- Dava pra colher alguma coisa?

- (José) Somente com esteira, nóis tinha aqui uns problema sério de colher, nós colhia com a esteira na colhedeira, daí colhia, se não perdia 
100\%. Os vizinho aqui que não tinha esteira que nós não podia fornecer perdia a colheita.

- (João) Completando a conversa dele, a gente preparava a terra na seca, quando não tinha esse problema, então era só na colheita que dava o problema né, e o plantio, nessa época, ainda não vinha chuva pesada né, a chuva vem se agravar de dezembro pra frente, época da colheita. Em toda terra aqui, problema é quando acumulava chuva, de novembro a fevereiro.

- Como é feito o trabalho de drenagem dos solos?

- (José)Bom, veio o pessoal aqui da Drenomat, foi na nossa área, nós marcamo as primeira, analisou a área, fez um projeto, que ele tem outra empresa, que vem e faz o projeto, e dai foi na FEMA, aprovaram, fizeram os levantamentos, e fizeram as vala conforme, até eles tem um trabalho de fazer bem em nível, tudo em nível, pra não dá erosão, pra não dá excesso de caída. Primeiro levantaram o projeto em cima, estudaram lá em São Paulo, acho que em São José do rio Preto, daí vieram com o projeto, conforme o projeto mandou...,eles escavaram pra ver a umidade, implantaram as valetas em cima do projeto estudado.

- O que isso causa?

- Simplesmente a água que é recebida pela terra é escoada por essas valeta. De outra forma quero falar, não fica mais a água da chuva em cima da terra esperando a umidade do ar tirar. Então, a água que cai da chuva, tem a cada 200-300 metros uma valeta, ela cai escoando e vai sempre saindo, não fica depósito de água na área. Então, chove hoje, a umidade sai à noite, se chove à noite, até meio-dia já escorreu tudo, não tem mais aquele problema de ir acumulando água de 4-5 dias e não ter escoamento, simplesmente tinha de secar com o nosso tempo aqui, sem valeta, com o sol, que vai retirando a umidade do solo e passando para o ar. Então pra nós, eu acho que foi o que resolveu, essas valeta foi retirando a água que cai da chuva.

- E o benefício que isso causa?

- (João) O beneficio pra nós é $100 \%$, porque teve ano aí que nós perdeu a colheita, né. Então o benefício é fora de série, resolveu o problema nosso, né. Nós tava indo mal, nós tava quebrando já, porque perdia a safra. Então o beneficio foi excelente, extraordinário. E quanto ao que o senhor perguntou, como é que é feito, é levantado uma área, é levantada a área, eles piqueteiam de 15 em 15 metros, uns traçado tudo diferente do que vai ser levantado. Ai eles acham o nível do terreno né, através do nível eles vão saber onde é a cabeceira, a nascente da água. Ai se tiver nascente na terra, é feito esse levantamento, é destinado... é começado de zero, da nascente, 300 metros da nascente o levantamento, e vai por essa área, toda essas água é jogada numa bacia, não em queda ou caída, alguma coisa assim, é jogado sempre pro lado da nascente da água pra não prejudicar a natureza ou coisa assim não é, 
então, eles levanta a área toda no computador, e vão achar o nível dos terreno né, ai é feito um escoamento da água pro lado que nasce o rio.

- Mesmo apresentando $100 \%$ de benefício, o senhor ressaltaria algum outro aspecto acerca da abertura dos valos?

- (João) Quando vieram falar desses valos nós não tinha conhecimento, quando nós soubemos disso aqui, fomos convidados a visitar uma área que foi feito, nós até não queria nem ver. Não queria nem participar, inclusive eu nem fui, o Zé foi, mas eu nem fui ver essa área porque achava que não tinha cabimento né. Aí foi que um vizinho fez, a gente viu, e achava que perto dos valo, ou coisa assim, quando passava água, podia vim fazer prejuízo né, podia secar na beira do valo, vamo dizer, e você plantar e não chover, tem de chover muito para recuperar aquele pedaço, na beradinha, de 1 metro e meio de fundura, né. Mas nós fizemos um projeto pequeno no primeiro ano, plantamo e fomo ver que não muda nada, nem 20-30 cm na beira dos valo, não muda, a terra vem lá do meio, vem normal até ali do jeito que nasce a planta, na beiradinha do valo, nasce lá no meio e assim por diante. E fomo ver que o nivel da água também não baixou na seca, não mudou nada, ficou a área que era, e aí foi que nós acabamo fazendo o projeto.

- Observou alguma mudança no solo, algum tempo após a drenagem?

- (José) Não esperava por isso, achava que ia compactar mais o solo, mas eu não sei se é tanto pelo plantio direto, ou coisa assim, hoje, a área é muito mais fofa do que a área que chegava a alagar um pouquinho, porque quando baixava a água, a gente ia mexer com um terra dessa na seca, o pé-de-pato não entrava, né, hoje a nossa terra, em toda seca, qualquer lugar é trabalhada, né, é com pé-de-pato, é com arador, porque a gente tem conhecimento e tá trabalhando, ela tá mais fofa do que quando era área úmida e secava e virava na seca um tijolo, porque do jeito que ela secava antes, na seca, ela hoje, ela seca igual, ela não tá secando mais nem menos, simplesmente na época da chuva ela não tá apodrecendo o solo. Mas quanto a Ter notado que ela compactasse ou coisa parecida, não mudou nada. Dá pra notar que melhorou, nunca mais usamos pé-de-pato, até hoje, aí veio o plantio direto e ajudou né. Nunca mais nós trabalhamos com pé-de-pato com nada nessas terra aí.

- Além da estrutura do solo, puderam observar alguma outra mudança?

- (José) A umidade do ar prá nós é igual, nós não tem mais aquele problema por exemplo, dava aquele solão aqui, saía, tava queimando o braço de calor, pisava dentro da água que tava dentro da lavoura, né. Hoje você vai lá na lavoura, tem o sol quente, acabou de chover vem o sol, tá sequinha a terra, tá úmida, mas não tem água depositada, e quanto ao ar, o sol, a umidade não temo observado nada diferente. 
- Qual é a avaliação dos senhores sobre esta atividade de drenagem dos solos?

- (José) Se nós não fosse com os dreno, nós estaria aqui hoje com dificuldade de plantar a nossa lavoura, certo? Eu acho que nós tamos aqui hoje com a nossa área bonita, colhendo 50-55 por hectare, e temos um padrão de erosão, temo feito projeto, tá tudo em dia, né. Eu acho que pra nós foi um benefício, foi tudo o que precisava vir, pra nós conseguir sair da fossa na região. Porque nóis plantava teria que colher com esteira, dai apodrecia o soja, né, então pra nós foi uma luz que veio do fim do túnel, que resolveu o problema graças a Deus, eu acho que é tudo o que nós precisava, né, aí, tá pra todo mundo ver, nós os outros vizinhos que fizeram. Nós hoje planta e colhe muito bem. Só perdemo se chove e apodrece o grão e a colhedeira não pode entrar, agora, quanto a máquina entrar na lavoura, se nós perde o outro vizinho perde também, não é? Então foi a nossa solução, graças a Deus, graças ao projeto, ao pessoal da Drenomat que veio com esse projeto já de Primavera do Leste, eles trabalhavam lá e vieram aqui, começaram e fizeram muito projeto e fizeram muito serviço por aqui, em muitas fazendas, então pra mim, de minha parte foi gratificante.

- Qual é a expectativa dos senhores para esta região?

- (José) Nós esperamos cada vez colher bem, conseguir vender, nós vendemos soja como no Paraná por exemplo, $R \$ 3,00$ a menos que nas região mais perto do porto, né, e a nossa lavoura é mais cara, vai um pouquinho mais de adubo, mas nós tamos colhendo bem, uma média melhor que a do Paraná, eu acho que dá pra dizer que pro futuro, só se o soja, a planta, a agricultura brasileira não funcionar pra ninguém, né. Nós tamos numa área igual a todos do Brasil, e até mais produtiva, né. Outra coisa, falando mais um pouquinho do dreno, nós começamo plantar milho aqui depois do soja, porque nós tinha como, tinha uma terra que podia entrar pneu, colhia, entrar a plantadeira e colhia, e temo a safrinha do milho, né. Então de minha parte, em particular, eu acho que daqui pra frente, se a agricultura tiver futuro, nós tamos junto com os outros de todo mo Brasil, aqui nós tamos permanecendo no mesmo caminho, no mesmo cargo de todo mundo.

- Mais algum aspecto os senhores desejam registrar nesta entrevista?

- (João) Faço questão de falar que é um trabalho muito importante pra nós, o que o senhor, Prof. Prudêncio, está fazendo, e que uma pesquisa que seja séria, feita honestamente, certinho, pra facilitar Ter licença junto a FEMA, quando a gente tem que fazer alguma drenagem, que facilite, hoje eles tão até meio parado com as licença pra drenagem, né. Então a gente acha que é um trabalho muito importante, que seja feito certinho, que se chegue a um ponto $X$ para Ter uma resposta pra FEMA, pois nós tem alguma dificuldade junto aos órgãos pra conseguir fazer esse trabalho, né. 
- (José) Agradeço a vocês, a Universidade Federal que veio aqui, né. Veio o Prof. Ximenes, a Prof ${ }^{a}$ Selma, a Prof ${ }^{a}$ Célia, então o que nós pudemos fazer de apoio nós vamos fazer. Vamos tentar ajudar e queremos tirar umas dúvidas, né, do que pode acontecer. Queremos que a FEMA, o meio-ambiente, seja esclarecido do que tá acontecendo, não das conversa fiada que tem da coisa real, dos estudos né, pra não prejudicar a natureza, não prejudicar o meio-ambiente, não prejudicar os bichos Que tá por aí. Nós temos certeza que tá correto o que vocês tá fazendo. E agradecer mesmo de coração ao senhor Prof. Prudêncio, e estamos a disposição, que esteja do nosso alcance.

- Agradeço também de coração a entrevista dos senhores, um depoimento bem esclarecedor, compartilhando conosco um pouco de suas vidas e suas lutas, mostrando um tanto da história e da ocupação desta região de Mato Grosso, como também o apoio que vocês estão dando à nossa pesquisa, que faz parte do curso de doutoramento em Geografia Física pela USP e estamos levantando os dados, não temos nenhuma conclusão por enquanto, e semente depois dos dados levantados, bem analisados é que poderemos apresentar alguns resultados e conclusões. Esperamos que os resultados desta pesquisa venham a fornecer subsidios aos senhores que estão aqui com as suas famílias, utilizando a terra, plantando, produzindo e promovendo e desenvolvimento de Mato Grosso.

Agradeço aos senhores pela entrevista, e ao apoio que juntamente com as suas familias, estão dando ao desenvolvimento desta pesquisa. 